\title{
CUERPO \\ Hacia el espacio doméstico contemporáneo
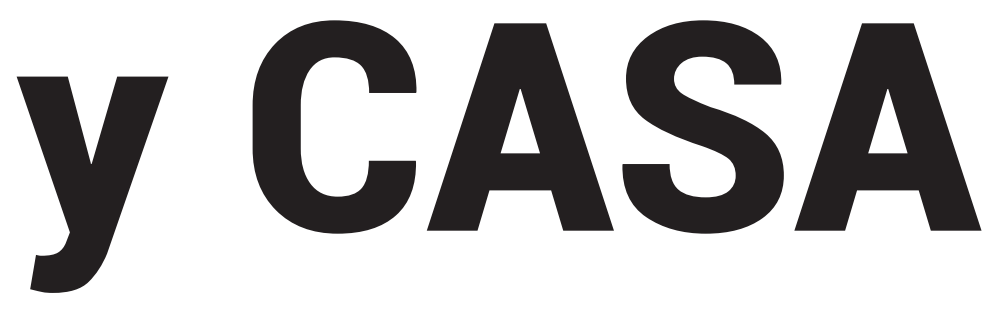 \\ desde las transformaciones de la cocina y el cuarto de baño en occidente
}

TESIS DOCTORAL 
Escuela Técnica Superior de Arquitectura de Madrid.

Universidad Politécnica de Madrid.

Tribunal nombrado por el Magnífico y Excelentísimo Sr. Rector de la Universidad

Politécnica de Madrid, el día de

Presidenta Dña.

Vocal D.

Vocal Dña.

Vocal D.

Secretario D.

Realizado el acto de defensa y lectura de la tesis 'Cuerpo y Casa. Hacia el espacio doméstico desde las transformaciones de la cocina y el cuarto de baño en occidenté

el día de de 2016 en

Calificación_

La presidenta

Los vocales

El secretario 


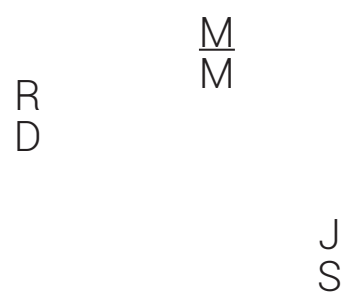

B

$\begin{array}{cc} & M \\ C & L\end{array}$

E

A ti.

¿A quién si no?

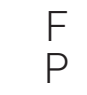

$\frac{P}{P}$

$$
\text { A }
$$

$A$
$R$ 


\section{Índice}

Resumen / Abstract

Primer capítulo. COCINA

De la fogata a la cocina modular

El fuego y el calor.

La domesticación del fuego

La conducción del fuego

La cocina como pieza independiente

La segregación de la casa

Espacios y habitantes servidores y servidos

La intimidad

La familia y la reducción de la vivienda

El olor y la transformación del mundo sensible La cocina moderna de varios fogones

La eficiencia del trabajo doméstico El ama de casa y la reorganización de la cocina

EI desarrollo de la electricidad La mecanización de la casa

EI problema de la vivienda.

La cocina mínima europea.

Industrialización y estandarización La cocina modular y sus tipos 
Segundo capítulo. LIMPIEZA CORPORAL Y EVACUACION

Del río al cuarto de baño estándar La aparición del lavabo
Los ríos y arroyos.

La limpieza corporal y la exoneración en el entorno natural

Los grandes edificios públicos de la Antigüedad La cultura de la regeneración y las letrinas comunitarias

La nueva cultura medieval

La desaparición del baño y las funciones de eliminación en el espacio público residual

La importación del baño turco Las bañeras comunitarias

La ideología del cuerpo y la enfermedad La desaparición del baño

La transformación de los códigos de comportamiento

La apariencia y el espectáculo

$$
\text { El aseo seco }
$$

La domesticación de la evacuación

La revolución del olor

El primer inodoro y el cierre hidráulico

La medicina moderna.

La reaparición de la ducha

La teoría bacteriana.

La cultura de la higiene

Las redes de suministro y depuración del agua El cuarto de baño completo en casa

El hotel como nuevo tipo residencial El cuarto de baño compacto americano

El problema de la vivienda.

El cuarto de baño mínimo europeo El inodoro portátil

\section{Tercer capítulo. COCINA, HIG IE NE Y EVACUACIÓN}

De la estandarización a la diversidad global

El capitalismo de consumo

La cocina-taller tecnificada de la casa americana

La revolución de género

Los nuevos usuarios de la cocina

Los nuevos modos de vida

$$
\text { Almacenaje, consumo y tecnología }
$$

El cuerpo como objeto de consumo Hedonismo y placer en el baño La dieta saludable en la cocina

La diversificación de los ámbitos húmedos De la cocina y su desaparición

Del cuarto de baño y su atomización

La nueva ideología ecológica

El consumo sostenible en los talleres del cuerpo

La vivienda expandida y aumentada
Conclusiones

Bibliografía 


\section{Resumen}

Los ámbitos vinculados tanto a la preparación de los alimentos como al cuidado del cuerpo revelan las transformaciones de la domesticidad a lo largo de la historia y permiten analizar los cambios más radicales de la casa y sus habitantes.

Desde las primeras hogueras, el cocinar ha implicado un lugar, que una vez vinculado al habitar construido ha ido desplazándose por el espacio doméstico, ampliándose y reduciéndose, alejándose o acercándose al resto de los espacios de la casa en función de distintas variables tecnológicas, sociales e ideológicas y siempre en relación con procesos de segregación de los habitantes, en los que la mujer ha jugado un papel protagonista.

Por otra parte, las dos funciones principales del baño, limpieza y exoneración, en su origen coincidentes en los ríos, recorrieron separadas una trayectoria compleja que supone el tránsito de lo público a lo privado, de lo sucio a lo limpio y de lo simbólico a lo funcional hasta que a mediados del siglo XIX se instalan definitivamente en el espacio doméstico como consecuencia de variables sociales y tecnológicas.

Durante el siglo XX, las transformaciones de la cocina y el cuarto de baño pueden VIII ser analizadas conjuntamente dentro del espacio de la vivienda, revelando cambios muy significativos, especialmente en su segunda mitad, a consecuencia de las nuevas prácticas de consumo, las revoluciones de género, la globalización de la sociedad de la información y otros factores que provocarán que estas dos piezas se conviertan en el escaparate de unos nuevos modos de habitar en casa.

La cocina y el cuarto de baño son, en estos comienzos del siglo XXI, términos que aluden al espacio_tiempo doméstico de una vivienda diversa, expandida en la ciudad y aumentada en el mundo virtual.

Por un lado, el cuarto de baño, como unidad o atomizado, funciona como el taller de mantenimiento del cuerpo sin género, en el que las actividades higiénicas básicas dialogan con lo lúdico y proporcionan un placer saludable, sostenible y responsable, que convive con el desequilibrio psíquico de un cuerpo perfecto, eternamente joven, protésico y anabolizado
En consecuencia la cocina es un término en continua revisión, sin más definición física que las de unas regulaciones caducas ajenas a sociedad de la información: un ámbito en el que se desarrolla una cotidianeidad acelerada vinculada a unos inquilinos tan diversos como desconocidos. Su segmento abarca desde unos hábitos de consumo de un mundo global atravesado por la conciencia ecológica y de la sostenibilidad, la crisis y la preocupación por un cuerpo sano apoyado en una nutrición responsable, hasta los cuerpos obsesionados con la estética de la imagen que apenas requieren alimentos cocinados y que coinciden con los que tampoco pueden hacerlo porque carecen de medios.

Esta tesis estudia y relaciona la evolución de estos dos ámbitos domésticos, cocina y baño, en un tiempo y en un espacio expandido y aumentado, a través de distintos indicios de transformación con el fin de establecer un diagnóstico de futuro en una era de domesticidad mutante como la nuestra. 


\section{Abstract}

The areas related to both food preparation and body care, reveal the transformations of domesticity throughout history and allow for the analysis of the most radical changes experienced in/inside/within the houses and its inhabitants.

Since the first bonfires, cooking has implied a place, which once linked to the living that evolved, has been constantly displaced within the domestic space. It has been experiencing expansions and reductions, and it has distanced or approached/approximated itself to the rest of the spaces of the house depending on different technological social and ideological variables, and always relating to processes of segregation of the population, in which women have played a leading role.

Furthermore, the two main functions of the bath, cleaning and exoneration, in its origin coinciding in rivers, separately going through a complex trajectory which represents the transition from the public to private, from the dirty to the clean and from the symbolic to the functional until the mid-nineteenth century, when they both was finally get installed in the domestic space as a result of social and technological variables.

Throughout or during the twentieth century, both kitchen and bathroom transformations can be analyzed in conjunction or together within the space of the house, revealing very significant changes, especially during the second half of the century, as a consequence of the new consumption patterns or practices, the gender revolutions, the globalization of the information society and other factors that will cause that these two parts become or turn into the showcase of new ways to inhabit the house or of living at home.

At the beginning of the 21 st century, the kitchen and the bathroom are terms that refer to the domestic space-time of a diverse housing, expanded in the city and augmented/enhanced in the virtual world.

On the one hand, the bathroom, as a unity or atomized, works as the maintenance shop of the genderless body, where basic hygienic activities converse with the playfulness and provide a healthy sustainable and responsible pleasure/ enjoyment/recreation, which coexists with the psychic imbalance of a perfect body, eternally young, prosthetic and anabolized.
As a consequence or result, the kitchen is a term under constant revision or continuous review, without any other physical definition to that of some deciduous regulations far from the information society; an area where an accelerated ordinariness develops that is linked to some tenants as diverse as unknown. Its segment ranges from some global world consumption habits, going through or passing through the ecological and sustainability consciousness or awareness, the crisis and the concern about a healthy body based upon a responsible nutrition, to the bodies obsessed with the aesthetics of the image that barely require cooked food and that coincide with the ones that cannot do it either because they lack the means.

This thesis studies and relates the evolution of these two domestic aspects, the kitchen and the bathroom, in a time and an expanded and augmented/enhanced space, through different transformation signs with the purpose/objective/ object of establishing a future diagnosis in an era of mutant/changing/shifting domesticity like ours. 


\section{Estrategia de realización / Estructura}

La elaboración de esta tesis ha sido el resultado de dos años y medio de estudio basado tanto en una amplia bibliografía fundamental del habitar arquitectónico, como en otras tantas publicaciones específicas de la cocina y el cuarto de baño. Sin embargo, para su realización, han sido necesarios otros documentos aparentemente alejados de la edificación, pero que en torno al cuerpo, a los objetos, a la ideología y al espacio doméstico han posibilitado acceder al conocimiento del campo de esta investigación desde la filosofía, la antropología, la economía y la sociología. De cada una de estas fuentes, acompañadas por informaciones puntuales extraídas de los medios de comunicación, se han seleccionado imágenes, cuadros, datos y citas que han permitido hilvanar un relato propio que permitiera justificar y desarrollar el tema de tesis.

Un relato hipertextual, en el que palabras e imágenes dialogan entre síconstruyendo un discurso razonado e interdisciplinar de la casa a partir de un cuerpo fisiológico que habita un espacio a lo largo de la historia occidental, poniendo de manifiesto la ausencia de los arquitectos en la formación de dicho ámbito hasta apenas hace un siglo, habiendo sido la ideología y la tecnología las responsables de la transformación de la vivienda.

Con un desarrollo cronológico, la investigación se organiza en tres capítulos en el que ha sido necesario realizar reducciones y simplificaciones -a veces rozando la frivolidad- que permitieran hacer visibles los argumentos expuestos. Aunque no siempre se ha conseguido.

\section{Primer capítulo.}

COCINA_de la fogata a la cocina modular.

A partir del concepto del cocinar como primera actividad humana, se detectan aquellas variables tecnológicas, políticas, económicas e ideológicas que, poco a poco, definen el espacio culinario doméstico hasta llegar a la cocina estandarizada y modular de la primera mitad del siglo XX.

\section{Segundo capítulo.}

LIMPIEZA CORPORAL Y EVACUACIÓN_del río al cuarto de baño estándar.

La definición del término 'cuarto de baño', que aparece por primera vez en la casa burguesa de mediados del siglo XIX, es el punto de partida que permite realizar un análisis retrospectivo, y de nuevo interdisciplinar, de este espacio cuyo origen comienza en los ríos, lugar donde las funciones de limpieza del cuerpo y evacuación coinciden, hasta alcanzar la célula compacta higiénica y popularizada en la década de 1930.

\section{Tercer capítulo.}

COCINA, HIGIENE Y EVACUACIÓN_de la estandarización a la diversidad global

La cocina y el cuarto de baño son dos ámbitos plenamente asumidos en la vivienda de la segunda mitad del siglo XX que se ven radicalmente transformados por las revoluciones de género en los años 60 y de la información en los 90, donde aparecen unos nuevos modos de vida tan diversos como complejos que acaban por determinar la disolución del espacio doméstico. 

. COCINA. De la fogata a la cocina modular 


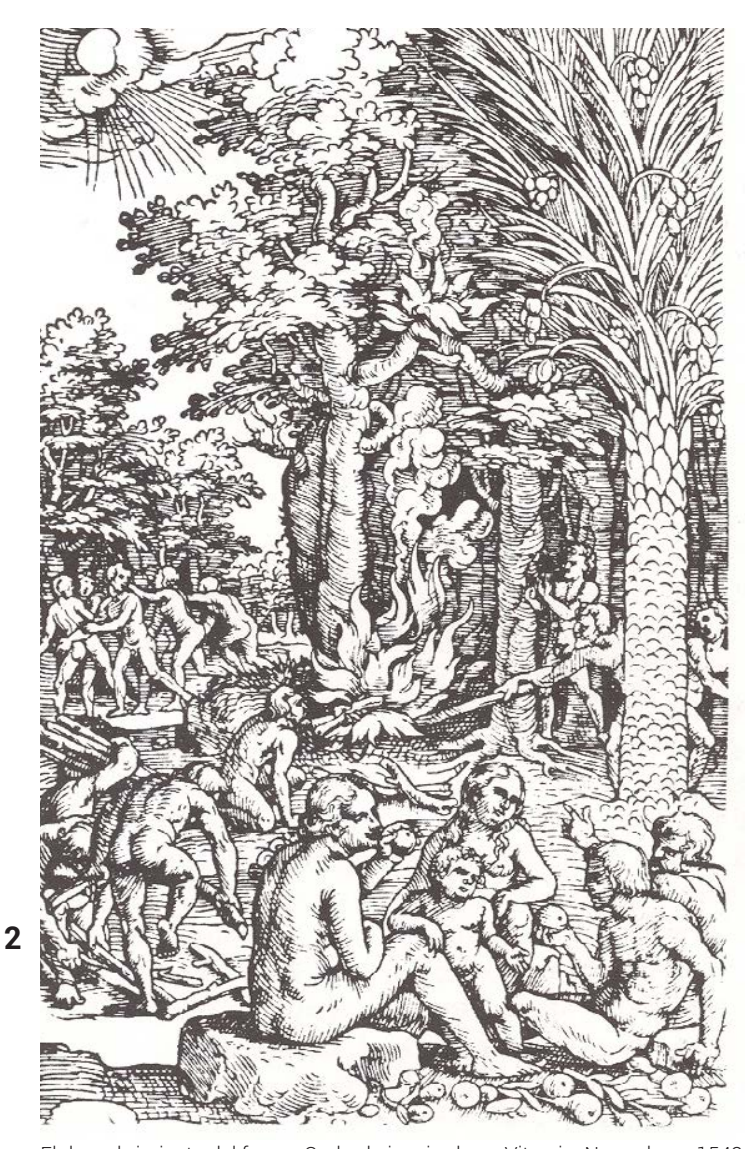

El descubrimiento del fuego. Grabado inspirado en Vitruvio. Nuremberg, 1548
Cocinar es lo primero Cocinar es la primera actividad humana ${ }^{1}$. Es además el acto con el que comienza la cultura². Mientras que la alimentación es una necesidad fisiológica común a todos los seres vivos para asegurar la supervivencia, la manipulación previa de los alimentos es una tarea exclusiva del ser humano ${ }^{3}$ que cambia históricamente con cada civilización y cada cultura ${ }^{4}$.

El descubrimiento del fuego Antes de cocinar, el homínido, crudívoro y no hablante, movido por la necesidad natural de comer, explora diariamente el medio en busca de alimento invirtiendo la mayor parte del tiempo en esta actividad. Sin horarios fijos que regulen la frecuencia de la alimentación diaria, la experiencia es lo que impone el ritmo para adecuar de modo óptimo la ingesta de alimentos al gasto energético realizado.

Sin embargo, no es hasta los alrededores del año 1.000.000 antes de Cristo, en el Paleolítico ${ }^{6}$, cuando el Homo Erectus descubre el fuego por accidente, como fuente de calor y luz ${ }^{7}$, y se transforman por completo una multitud de hábitos de la vida cotidiana, entre ellos la alimentación.

La posterior domesticación del fuego ${ }^{8}$, ya en el año 500.000 antes de Cristo, gracias al invento de diferentes métodos para provocarlo9, constituye uno de los avances tecnológicos de mayor importancia en el proceso de la evolución humana, que da lugar a las primeras fogatas y que, a su vez, entre otros aspectos, aumenta la densidad de la población del planeta ${ }^{10}$. Massimo. 2006.10)

5 En toda sociedad, entendida como forma de cultura organizada y evolutiva, existen unos hábitos gastronómicos característicos y diferenciadores, así como una infraestructura que los sustenta. Un pueblo organizado y cívico crea una manera culta de alimentarse, al igual que diseña una manera de vestirse o una forma de construir sus casas y sus ciudades. Y este conjunto de hechos, que configuran cada uno de los diferentes períodos de nuestra historia, repercute en el espacio culinario.

ce. 1966. 15.

7 En el libro II del tratado De Architetectura, Vitruvio describe el descubrimiento por azar del fuego y su posterior domesticación: Los hombres en los antiguos li continua confricación de sus árboles y densísino fieras, y vivían sustentándose de pastos silvestres. Sucedió en cierta ocasión encenderse cierto bosque a punto; pero mitigado después, se fueron acercando; y advirtiendo ser de una gran comodidad para los cuerpos añadieroric nuevo pábulo al fuego nue quedaba, lo conservaron, y fueron convocando a otras gentes, a quienes por señas iban informando de las utilidades del fuego. (Vitruvio, De Architectura. Ed. Ortiz y Sanz 8 En este caso, por domesticación entendemos
primeros homínidos de provocarlo y controlarlo. - Uno de los primeros métodos para provocar fuego es la percusión, es decir, por el choque entre una piedra dura como el silex con otra roca rica en hierro como la pirita generando una chispa sobre algún material seco y soplando en ella hasta que brote la llama. Como es evidente, esto permite no depender de los 


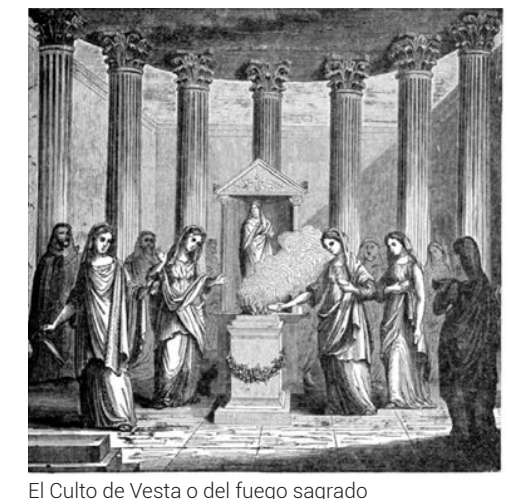

Culto de Vesta o del fuego sagrado

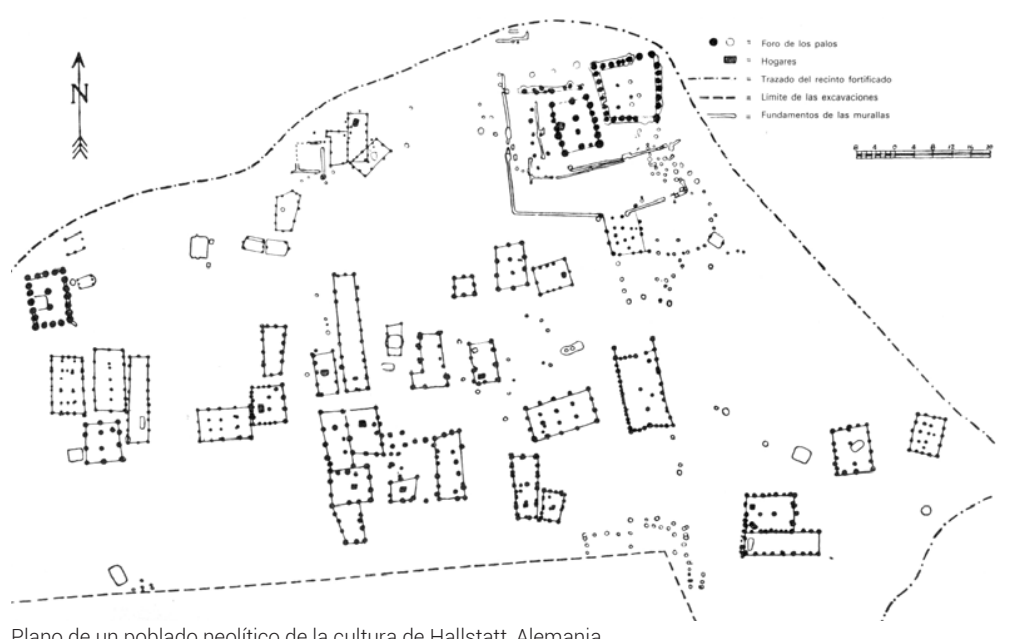

Plano de un poblado neolítico de la cultura de Hallstatt, Alemania.

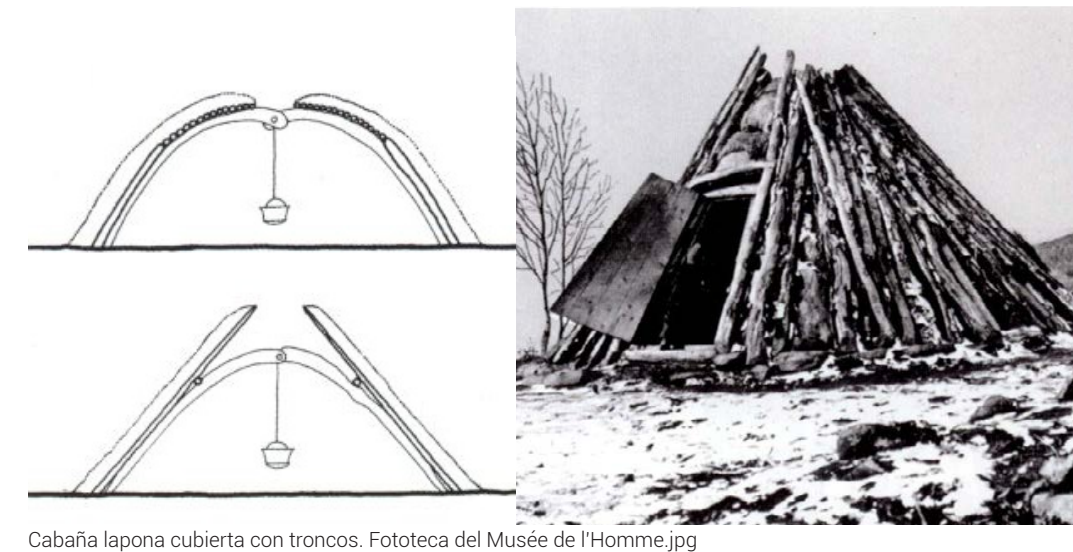

Cabaña lapona cubierta con troncos. Fototeca del Musée de l'Homme.jpg
Dada la dificultad técnica para provocar el fuego, este se convierte, junto al Sol, en un elemento venerado por muchas culturas de la Antigüedad; un bien preciado cuyo mantenimiento y conservación en muchas ocasiones es una ocupación sagrada ${ }^{11}$. De ahí su asociación a lo largo de la historia a los ritos del fuego inextinguible, a la chispa divina o al corredor de la antorcha ${ }^{12}$.

La aparición del hogar Las primeras hogueras constituyen un lugar de reunión y cohesión social ${ }^{13}$ que, una vez vinculado al habitar construido, conforma el hogar, un término que hace referencia a la doble condición de espacio térmico y lugar simbólico ${ }^{14}$ y que, en la actualidad, en muchas ocasiones utilizamos para denominar a nuestras casas aun cuando este elemento ha desaparecido.

Es el descubrimiento y el uso del fuego el que da origen a la sociedad humana, y con ella a la construcción de los primeros abrigos y chozas $^{15}$. La domesticación de este elemento supone el paso del fuego como ser natural al fuego como ser social16; un foco cuya organización espacial reproduce la concepción del cosmos, en torno al cual, y de una forma inédita, se estructura ambiental, social y simbólicamente el hábitat humano ${ }^{17} 18$.

Además de proteger contra el frío y ahuyentar a los posibles animales depredadores, el fuego se utiliza por primera vez para 'cocinar'; es alrededor de la hoguera donde, impulsado por la necesidad natural de comer -el hambre- el ser humano, en comunidad con otros, comprende la conexión entre el fuego, el calor y la transformación de los alimentos.
WRIGHT, Lawrence. Op. cit.15

Consecuentemente, es lógico que en las primeras culturas urbanas, que surgen en climas predominantemente cálidos, el papel simbólico del fuego -la

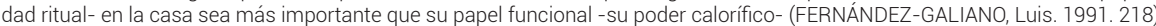

En las culturas antiguas Vesta es conocida como la protectora de Roma, diosa del Fuego y del Hogar, y segun la tradicion romana en su templo se custodia, siempre encendido, el fuego sagrado en su honor. Se la representa como una llama o como una matrona sosteniendo una antorcha, una pátera, una victoria o tambien un venablo y un cuerno de la abundancia. Sin embargo, para mantener el fuego es necesario la disponiblindad o bien de una techologia avanzada como

FERNÁNDEZ-GALLANO LLis. Op1. 217.

Esta idea de Vitruvio sobre el fuego se encuentra en su tratado de arquitectura De architectura. (Libro III, Capitulo ol). Segun Fernández-Galiano, tiene su origen en el evolucionismo epicúreo y, más allá, en los mitos del fuego de tantas sociedades primitivas (FERNÁNDEZ-GALIANO, Luis. Op,cit. 31-32).

16 BACHELARD, Gaston. 1966. 22

17 Arquitectura Viva 176

18 Además, 


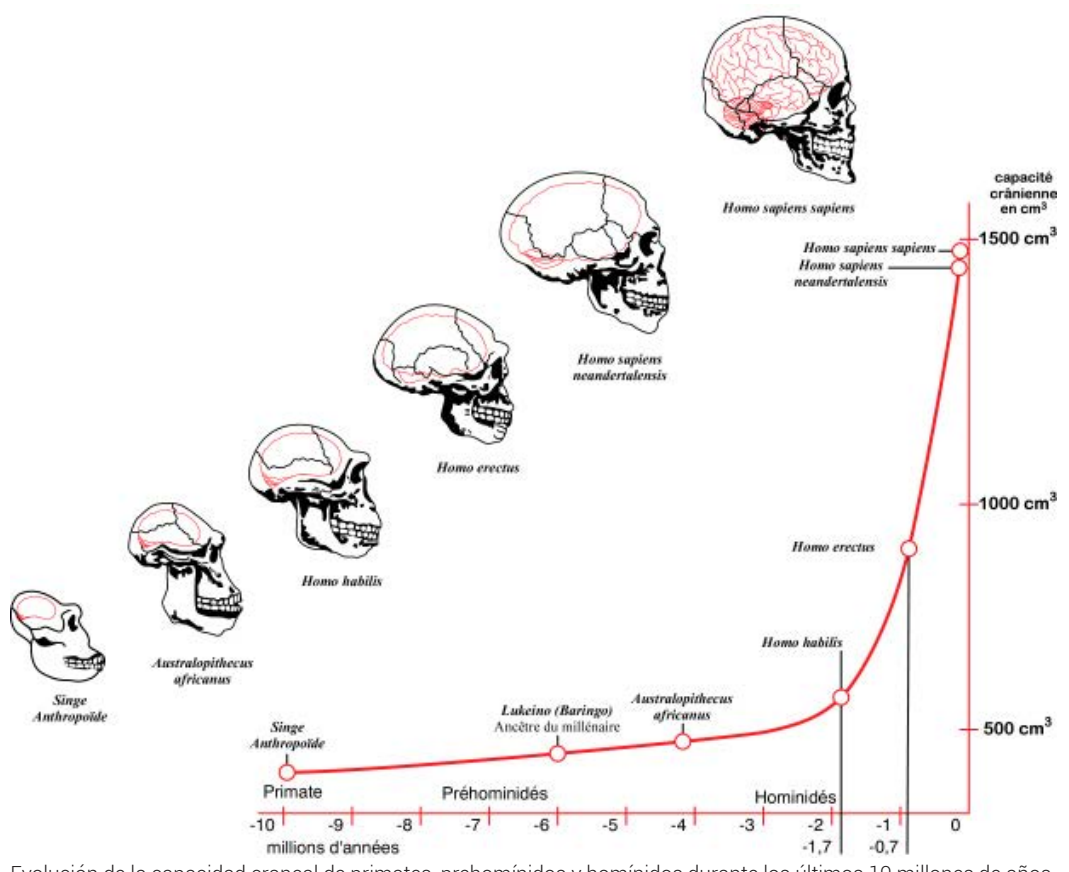

Evolución de la capacidad craneal de primates, prehomínidos y hominidos durante los últimos 10 millones de años.

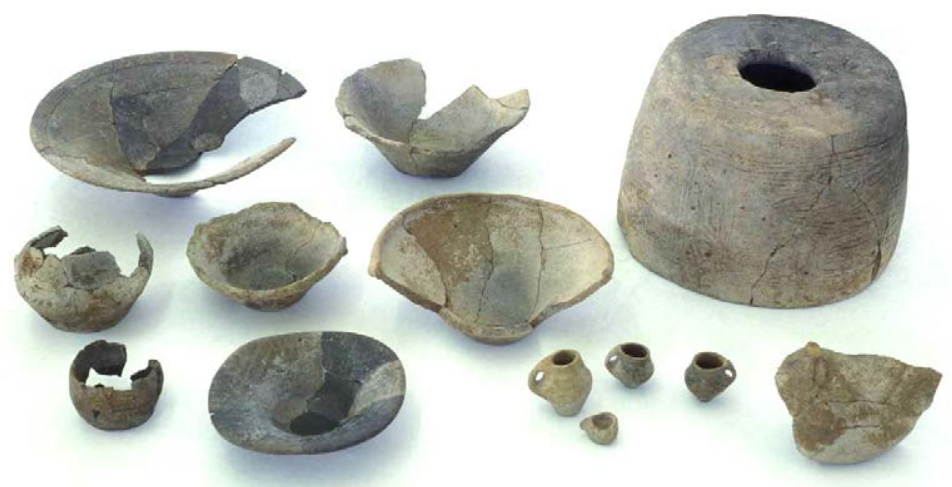

Cerámica empleada para cocinar y almacenar alimentos. Casa 4 del sector 6 de Dikili Tash, Grecia. Finales de Neolítico medio (hacia el 4300 a.C.).
De lo crudo a lo cocido El fuego aporta una profunda modificación del régimen alimenticio del homínido, que pasa de una dieta vegetariana a otra carnívora. Además, cocinar permite conservar durante más tiempo los alimentos, a la vez que reduce el riesgo de enfermedades, ya que el calor extermina parásitos y bacterias; pero lo más importante es que es la actividad responsable de la evolución del cerebro ${ }^{19}$ de la especie humana, ya que cocinar los alimentos implica un ahorro de energía corporal que posibilita realizar otras actividades además de las vinculadas a la supervivencia alimenticia ${ }^{20}$.

Durante miles de años, el asado es el único método conocido para cocinar Mediante la aplicación directa de la llama o de su calor sobre la pieza de carne, pescado o verdura ${ }^{21}$, los distintos alimentos se cocinan en la hoguera sujetados por algún sistema rudimentario de espetones ${ }^{22}$. Hay que esperar hasta la invención de la vasija de barro, en el año 7.000 antes de Cristo en el Próximo Oriente, cuando se produce la siguiente gran revolución culinaria: estos recipientes permiten no solo asar los alimentos, sino también cocerlos, calentar agua y preparar sopas, entre otros. Sin duda un gran avance que permite aprovechar vegetales, como muchos cereales y legumbres, que no se convierten en comestibles con solo asarlos. 

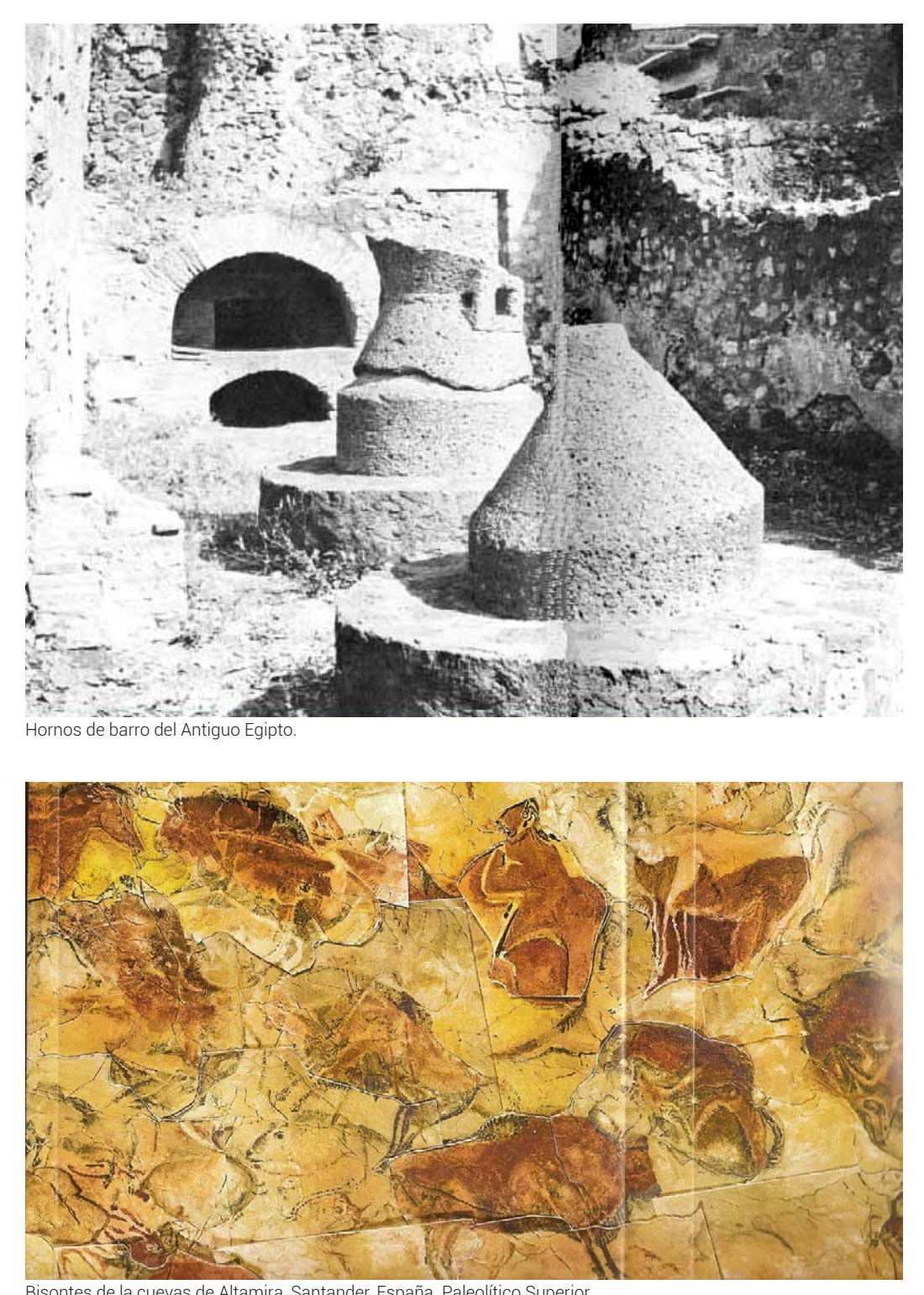

Bisontes de la cuevas de Altamira, Santander, España. Paleolítico Superior:
Mucho más tarde, hacia el año 5.000 antes de Cristo, la técnica culinaria mejora cuando aparecen, también en Egipto y en Babilonia, los primeros hornos de adobe, que permiten asar los alimentos de forma homogénea gracias a la refracción de las paredes, evitando el inconveniente del calor directo del fuego a la hora de asar. El horno es recuperado y desarrollado en su versión de ladrillo por la cultura romana, un elemento que, situado en sus orígenes fuera del espacio de la casa -adosado a una de las paredes del patio- es, junto a la aparición de la taberna y el sistema de conservación de los alimentos, una de las grandes aportaciones durante esta época para facilitar la tarea culinaria ${ }^{23}$.

Cocinar como proyecto Laaparición delos primeros poblados sedentariosconsolidala práctica de la cocina, una actividad que permite y exige elaborar proyectos ${ }^{24}$, dada la posibilidad de previsión objetivamente planificable. Por esta razón es comprensible que la dedicación intensa a esta actividad termine dando origen a la palabra, que en cierto modo es el verdadero agente que confiere la facultad de coordinar o proyectar acciones complejas para sí y para los demás, frente a las acciones de urgencia con la guía exclusiva de los datos ofrecidos previamente por los sentidos ${ }^{25}$.

De este modo el descubrimiento de la actividad culinaria, unido al lenguaje oral, permite al ser humano el ejercicio planificado de actividades según un proyecto que facilita prevenir el futuro transformando cualitativamente las actividades de la caza y la recolección y dando lugar a la agricultura y a la ganadería ${ }^{26}$.

Mientras 'el cazar conforme a proyecto' exige conocer y dominar el comportamiento de los animales durante períodos prolongados, culminando con la domesticación de muchos de ellos, también el mayor conocimiento de los ciclos temporales, así como el lugar de la producción de cosechas espontáneas, termina por revelar todo el ciclo vital de las plantas en provecho del ser humano. 


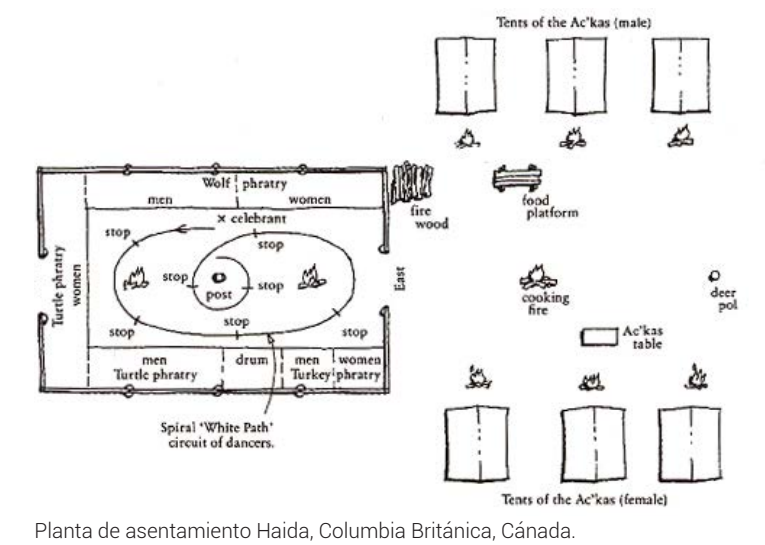

Planta de asentamiento Haida, Columbia Británica, Cánada.

6

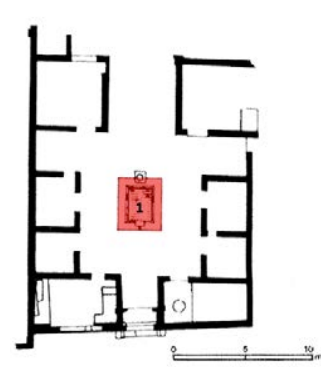

Casa del Cirujano, Pompeya, Italia, con el atrio

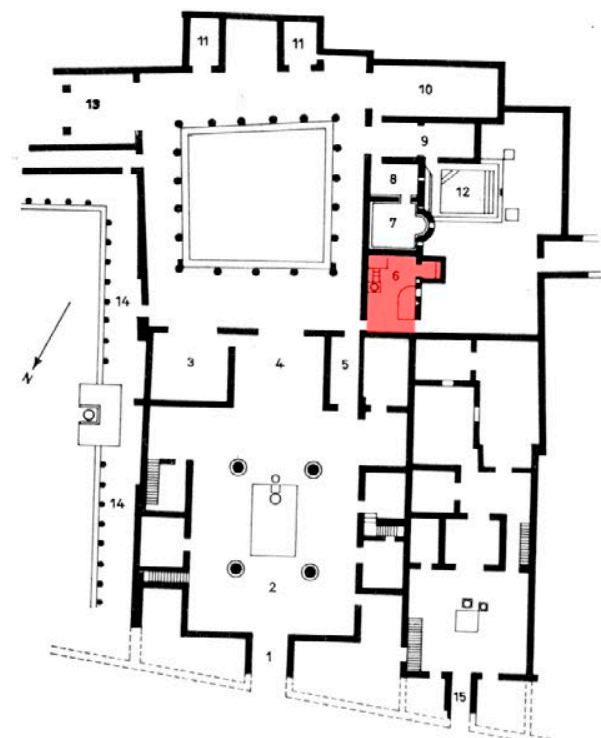

Casa de las Bodas de Plata, Pompeya, Italia. Principios del s. I d.C. (6) Cocina, (10) triclinio estiva
La organización del tiempo Junto a la actividad de cocinar, que por su naturaleza requiere de cierta cooperación, aparece en el Neolítico la organización del tiempo y una primera división del trabajo: mientras el hombre caza, pesca y recolecta, la mujer cuida de la casa y de los hijos, prepara la comida y confecciona la vestimenta ${ }^{27}$. Cuando los cazadores nómadas son sustituidos por labradores y ganaderos, el arte de cocinar mejora, ya que los alimentos pueden ser cocidos directamente sobre el fuego ${ }^{28}$. Desde el Neolítico, la actividad de cocinar se realiza en el exterior ${ }^{29}$ si el tiempo lo permite, o bien en un interior compartiendo espacio con otras actividades domésticas. Exceptuando las primeras civilizaciones de la Historia, como las mesopotámicas, las egipcias las indias, la cocina, entendida como una habitación diferenciada dentro de la casa, aparece por primera vez en el siglo $V$ antes de Cristo en la domus romana.

La culina romana La cocina romana o culina tiene su origen en la necesidad de encontrar una estancia en la que cocinar cuando el patio o atrium deja de ser el lugar donde se conserva el fuego del hogar ${ }^{30}$. Desde entonces el espacio de preparación de los alimentos se configura como una habitación de carácter secundario, pequeña, en torno a los 10-15 metros cuadrados, oscura y poco ventilada, ocupada en su mayoría por esclavos que cocinan. Sin duda una estancia que po su pequeña dimensión contrasta con la grandeza de los opíparos banquetes romanos, casi orgías culinarias.

Aunque no tiene un lugar definido como otras habitaciones dentro de la casa $^{31}$, se suele situar en una zona apartada, lejos de las habitaciones privadas y del espacio de consumo de alimentos o triclinum, para evitar ruidos, humos y olores desagradables. 


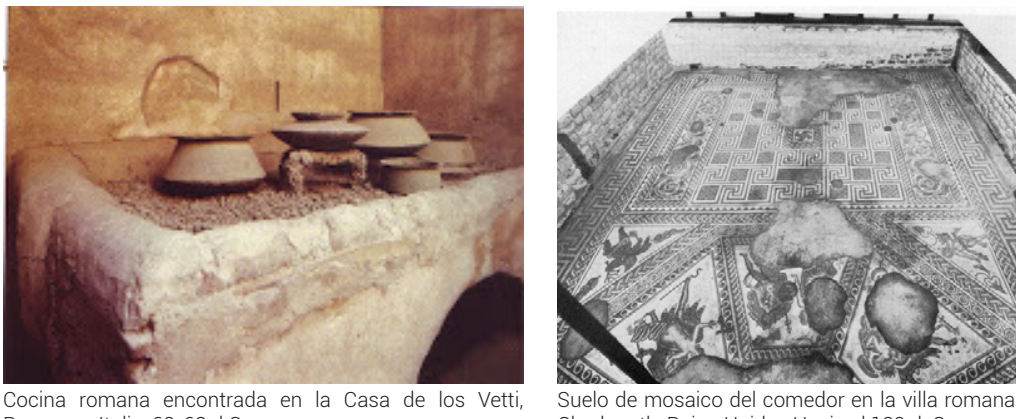

Cocina romana encontra
Pompeya, Italia, $62-68$ d.C.

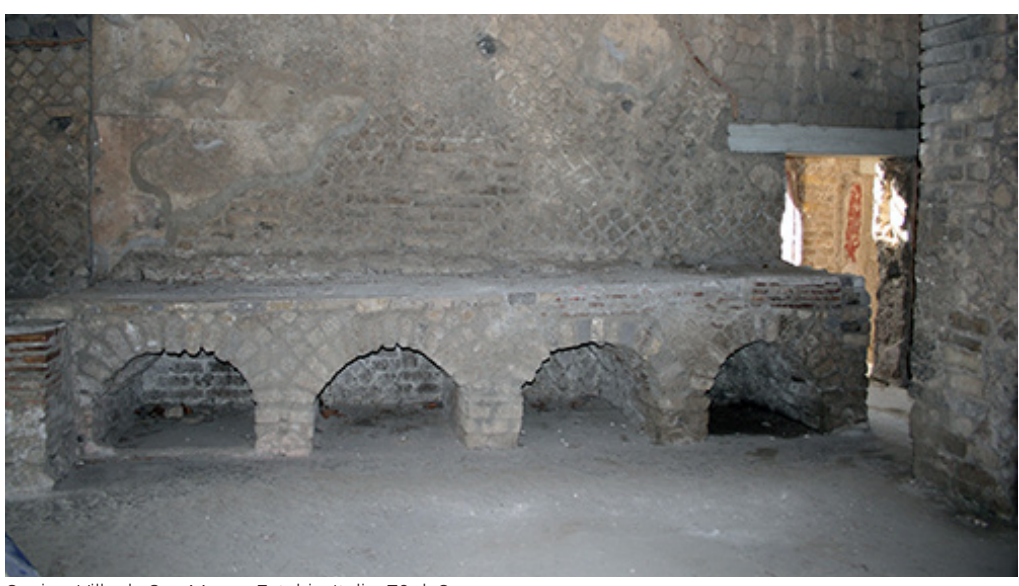

Cocina, Villa de San Marco, Estabia, Italia. 79 d. C.
El banco de obra Dentro de esta habitación el elemento fundamental es el fogón, un como fogón banco de obra adosado en el rincón de dos paredes, con una superficie superior plana, cubierta de losas o tejas de barro, para extender las brasas, que se refuerza con un reborde hecho con imbrices, tejas curvas, para proteger al cocinero de los rescoldos que pueden saltar del fuego ${ }^{32}$.

Debajo de la superficie hay unos huecos en forma de arco de medio punto que sirven para el almacenaje de leña; en caso de tener varios, se almacenan vasijas, aunque lo más frecuente es que la batería esté colocada sobre poyetes y baldas o colgada en argollas en las paredes que la circundan 33 . El conjunto de la cocina lo completa un pequeño fregadero de obra o un gran barreño de barro que se emplea para lavar la vajilla, de bronce en las casas ricas y de cerámica en las clases más populares, y la batería de cocina.

Algunas soleras se realizan de opus signimun, un tipo de pavimento preparado, elaborado con trozos de ladrillo o teja machacados y unidos con cal, al que se le añade aceite, creando una superficie impermeable y fácil de limpiar. También se han encontrado suelos con un simple preparado de tierra apisonada, menos higiénica, pero muy absorbente ${ }^{34}$.
32 La culina romana, además de ser el lugar en el que se preparan los alimentos, tiene también en muchos casos un carácter religioso, ya que allí se conserva el fuego del hogar. Se han encontrado altares dedicados a los lares, divinidades protectoras de la casa como Vesta o los Penates, justo encima o muy cerca de fogón, lo que representa ell lugar de su culto por parte de los servidores de la casa

al triclinum para mantener los alimentos en perfecto estado hasta el momento de ser servidos. traen sus propios hornillos con los alimentos? El lujo ha traído la moda de trasladar la cocina a la cena, para que la comida no se enfríe o no resulte lo bastante caliente para un paladar ya endurecido (SÉNECA, Epístola, 78).

s lóge ses es acio culinario más estructurado y jerarquizado. Y pequeñas dimensiones (ESPINET, Miguel. 1983. 23). 


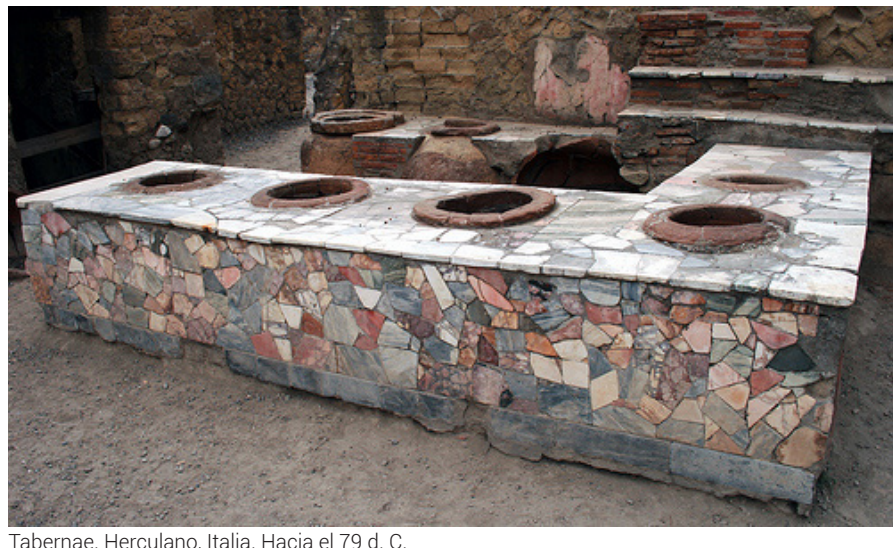

Tabernae. Herculano, Italia. Hacia el $79 \mathrm{~d}$. C.

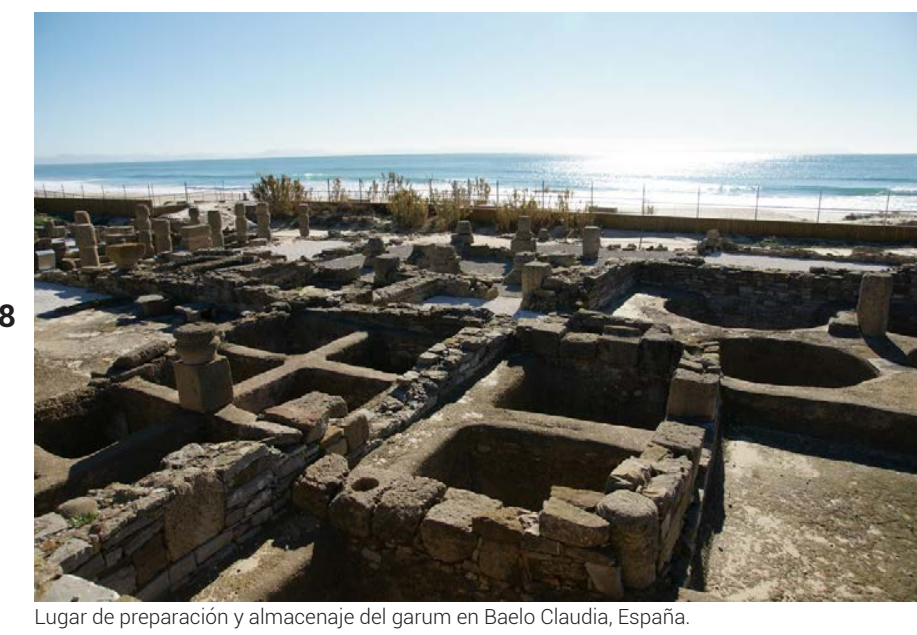

La tabernae romana Sin embargo, disponer de cocina individual en el espacio doméstico durante esta época es un lujo reservado solo a las clases más altas. Los habitantes de casas sin fogón visitan con frecuencia la taberna o tabernae de la planta baja de las casas, el embrión del barrestaurante $e^{35} 36$

La tabernae es un espacio vinculado a la casa que siempre se abre a la calle, al menos en una primera época, mediante una amplia abertura a través de un mostrador de piedra en el que se expiden comidas rápidas tipo gachas, puls o rancho ${ }^{37}$. Cubierto por unas piezas de mármol, en el mostrador se encuentran unas cavidades circulares donde se introducen las vasijas con el fin de mantener calientes los alimentos y las bebidas ${ }^{38}$. En la parte interior se ubica el taller, donde se fabrican productos que se ponen a la venta y el almacén de fruta y pan.

Sin embargo, a pesar de los adelantos realizados durante el período romano, el espacio destinado a la preparación de alimentos, ya sea a través de la culina privada o de la tabernae comunitaria, es un lugar al que los ciudadanos romanos apenas dotan de un soporte espacia y tecnológico adecuado, como ocurre con los baños, las termas públicas o los recintos de espectáculos. 


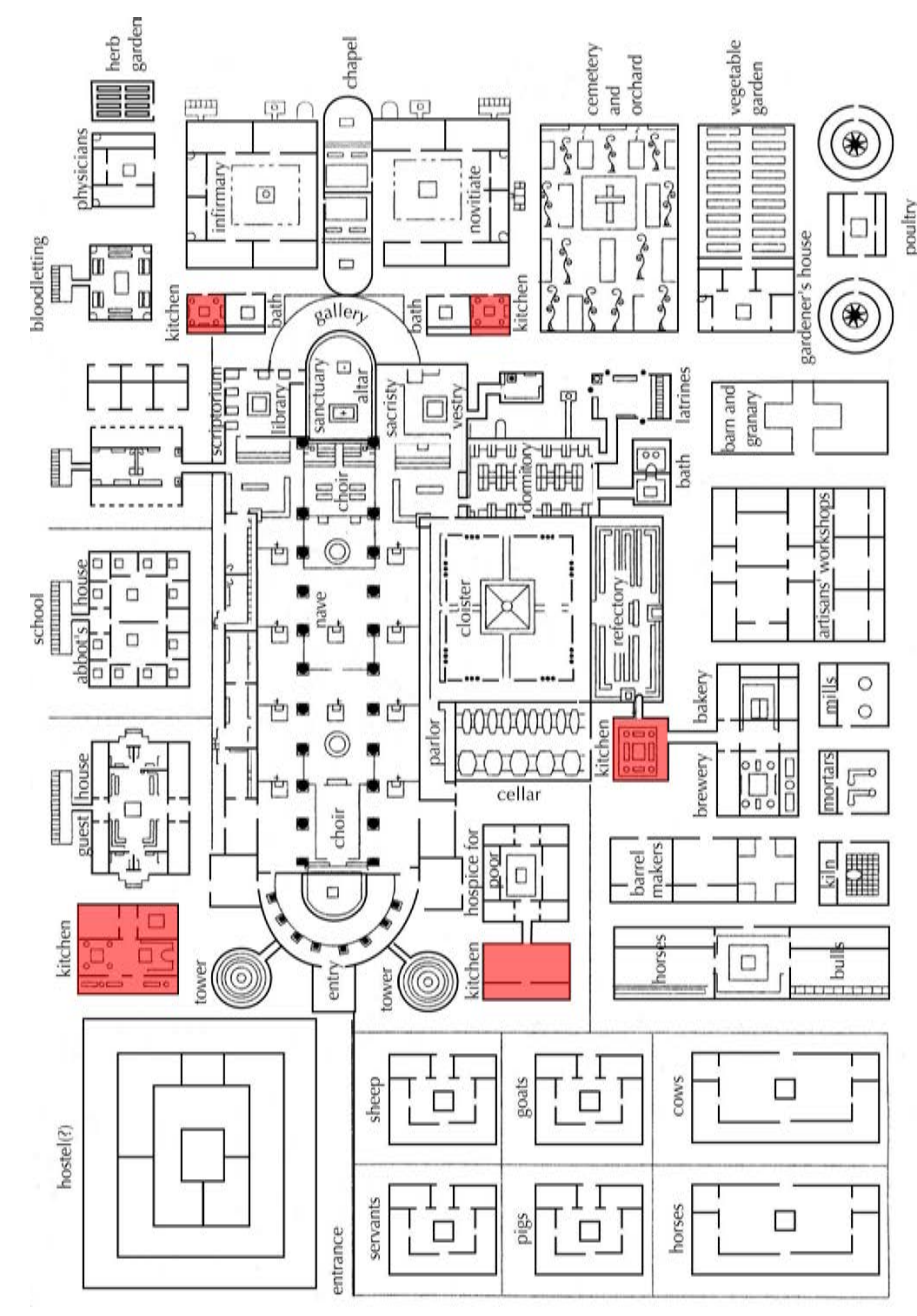

Plano esquemático de la abadía de San Galo, actual Suiza. Hacia el 820. Se observan las cinco cocinas del complejo asociadas respectivamente a la enfermería, casa de los novicios, refectori
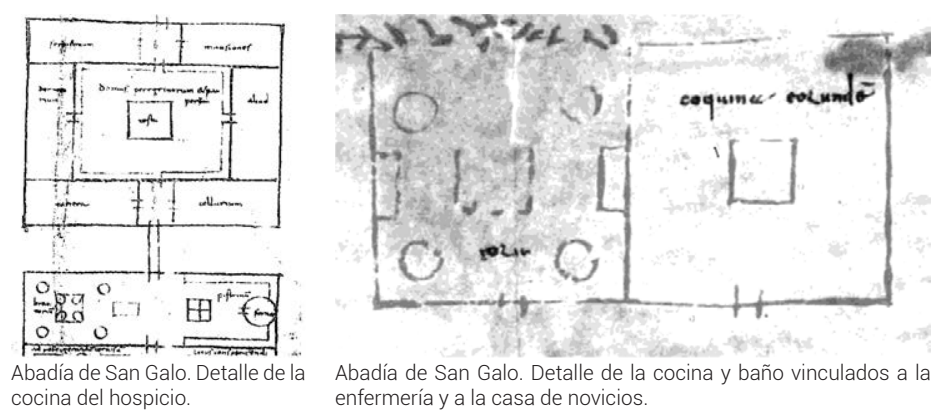

enfermería y a la casa de novicios.
Tras las invasiones de los pueblos bárbaros del centro de Europa en el siglo IV, la civilización clásica y el patrón de vida romano quedan arrasados. La cultura y el orden social que tanto tiempo tardan en consolidarse se ven eclipsados, perdiendo su significado hasta su recuperación a mediados del siglo XV.

Durante la alta Edad Media, el momento carolingio, comprendido entre los siglos VIII y IX, representa el mayor esfuerzo por recuperar la unidad cultural perdida entre las ruinas del mundo clásico.

Los innumerables monasterios y abadías que llenan Europa por estas fechas son los principales centros de cultura y desarrollo de la época. Pero también son el refugio y la posada para los peregrinos ${ }^{39}$, razón por la que sus cocinas, que deben servir cientos de comidas, se equipan con los mayores adelantos, con el fin de hacer la labor de los monjes un trabajo soportable.

La conducción del fuego Este hecho es el principal responsable de la aparición de una de las pocas aportaciones arquitectónicas durante el período medieval en la cocina: la chimenea.

En el plano del monasterio benedictino de Saint Gall ,en Suiza, -copiado a principios del siglo IX-, un microcosmos físico y social ${ }^{40}$, aparece por primera vez la representación de la chimenea, y, con ella, la introducción del confort térmico individual y segregado ${ }^{41}$. Sin embargo, no es hasta el siglo X, en la abadía de Marmoutier, cerca de Tours, cuando se hace realidad una de las primeras cocinas medievales que incorporan la chimenea. Su incorporación en el resto del espacio doméstico se produce posteriormente, ya en el siglo XV. 


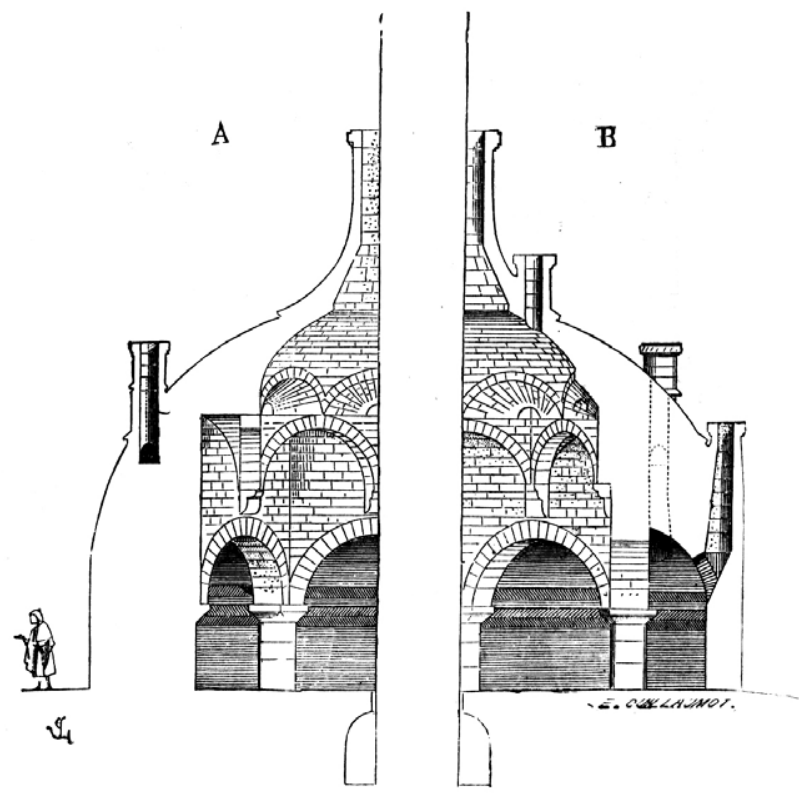

10

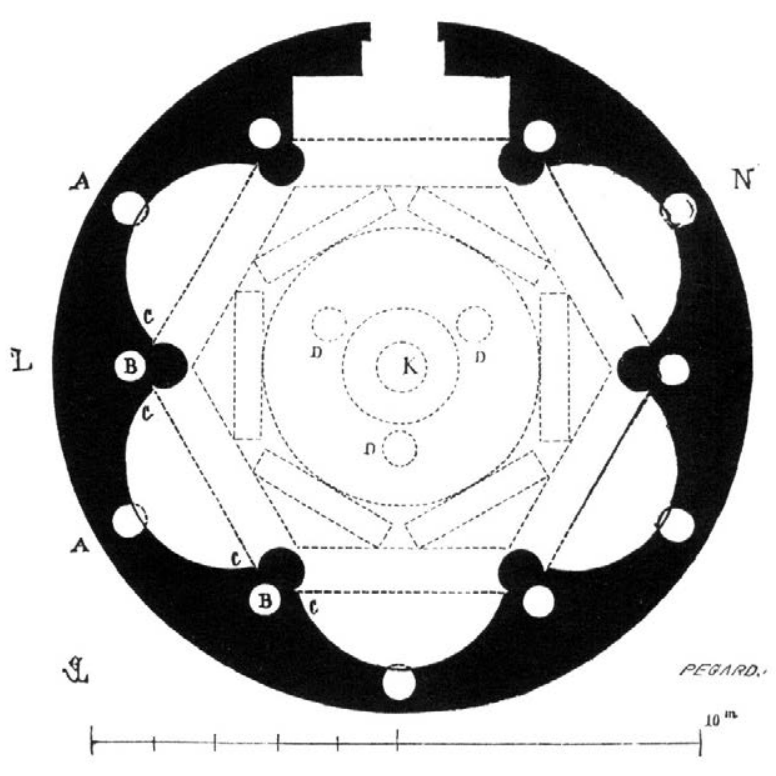

Sección y planta de la culina antiqua (cocina antigua) de la abadía de Marmoutier, Francia.
L cocina de Marmoutier o culina antigua es una enorme construcción aislada de piedra en forma de embudo invertido de planta circular con un diámetro de al menos doce metros: una superficie de 442 metros cuadrados de cocina. La bóveda acampanada está perforada por una chimenea o salida de humos central, situada por lo tanto en el punto más alto. El interior de la planta circular está compartimentado en seis subespacios, adosados a los muros exteriores, que cuentan con catorce chimeneas en total para impedir que el humo remita hacia dentro por efecto de las corrientes de aire. Además, la sala posee una extracción suplementaria para los humos que pueden escapar de cada chimenea y para la propia ventilación del espacio culinario ${ }^{42}$

La cocina comunitaria La invención de la chimenea se difunde por Europa entre los siglos XII y XIV43. Supone por primera vez la resolución de uno de los mayores problemas arquitectónicos que se conocen hasta el momento para ubicar las cocinas dentro de espacios cerrados: el de la evacuación de los humos. A través de un conducto, en principio fabricado en obra, se canaliza al exterior el humo provocado por el fuego de una cocina, un horno u otra fuente de combustión.

España supone una notable excepción en el desarrollo de la chimenea debido a la escasez de madera y a la amabilidad del clima. A pesar de que en algunos textos se afirma que hacia 1784 las chimeneas son prácticamente desconocidas en Madrid ${ }^{44} 45$, parece que su instalación aumenta paulatinamente desde el siglo XVI, convirtiéndose en el siglo $\mathrm{XVIII}$ en un elemento bastante frecuente en las casas de mayor nive económico, donde cumple un papel de representación ${ }^{46}$ en la mayoría de los casos. 


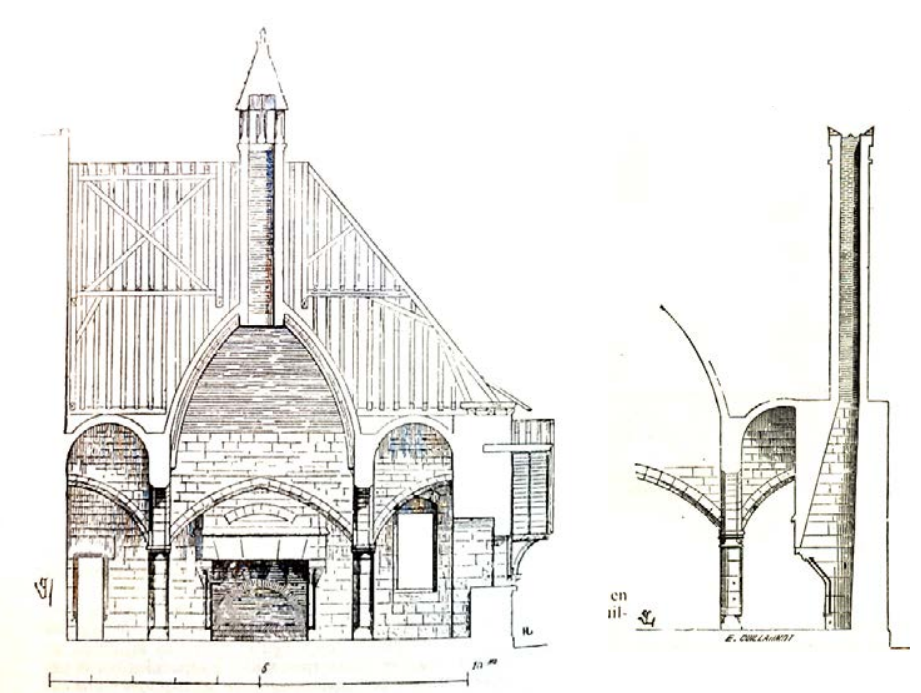

Sección de la cocina y del tiro de chimenea del castillo de Montreuil-Bellay, Francia.

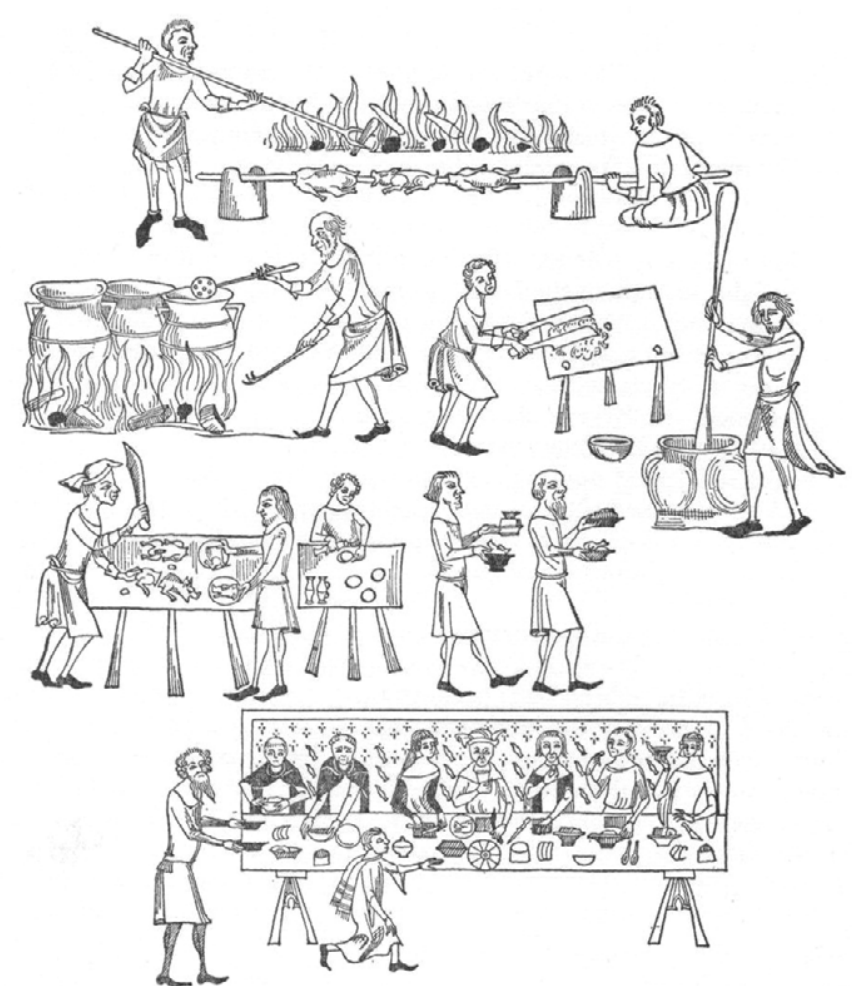

Festín medieval. Preparación de los alimentos en el exterior para su posterior consumo en el interior.
Junto a los monasterios, los castillos son las otras grandes construcciones de la época medieval cuyas cocinas son edificios aislados construidos de piedra o ladrillo con un diámetro que varía entre los cinco y los veinte metros, y, a diferencia de los monasterios, con pocas aberturas ${ }^{47}$

Es probable que el castillo de Langley, en Inglaterra, sea el primer lugar donde se experimenta con éxito la conducción de humos y vahos a través de un orificio de largo recorrido que, instalado en el espesor del muro, termina en los merlones de las almenas ${ }^{48}$.

La cocina como rito Con anterioridad a la disposición de chimeneas en los castillos, sobre todo a principios de la Edad Media, se cocina la mayor parte de las veces al aire libre ${ }^{49}$ 50. Las cocinas medievales primitivas son también edificios separados; a menudo frágiles construcciones desmontables de madera y paja que los reyes galos y germanos levantan allí donde residen una larga temporada. Por esta razón, y a favor de una necesaria protección de los débiles tejados, se ven obligados a edificar chimeneas de ladrillo y hornos de tierra, dando paso a las primeras organizaciones culinarias de la Alta Edad Media.

Mientras que la aristocracia vive en un castillo fortificado y los clérigos en un monasterio, el resto de la población, que es básicamente pobre ${ }^{51}$, habita en chozas de muros de adobe y techo de paja en pequeños asentamientos rurales distribuidos por el territorio. 


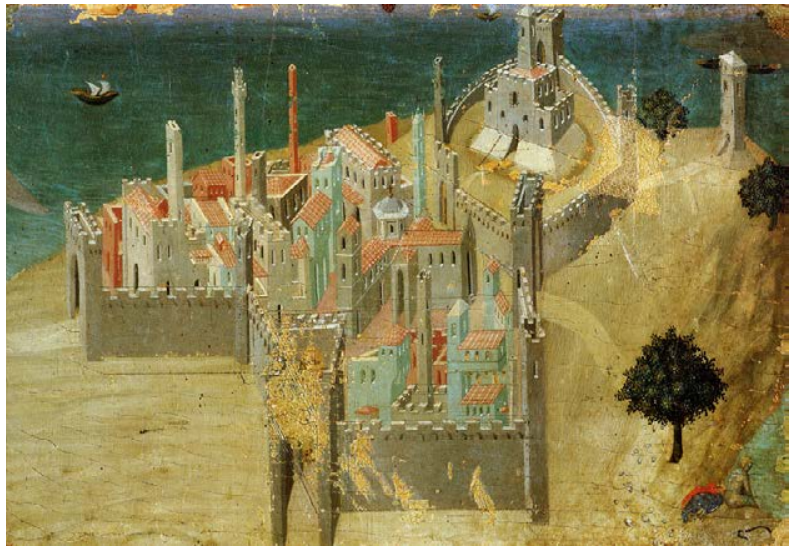

Ciudad junto al mar. Ambrogio Lorenzetti. Hacia 1335

12
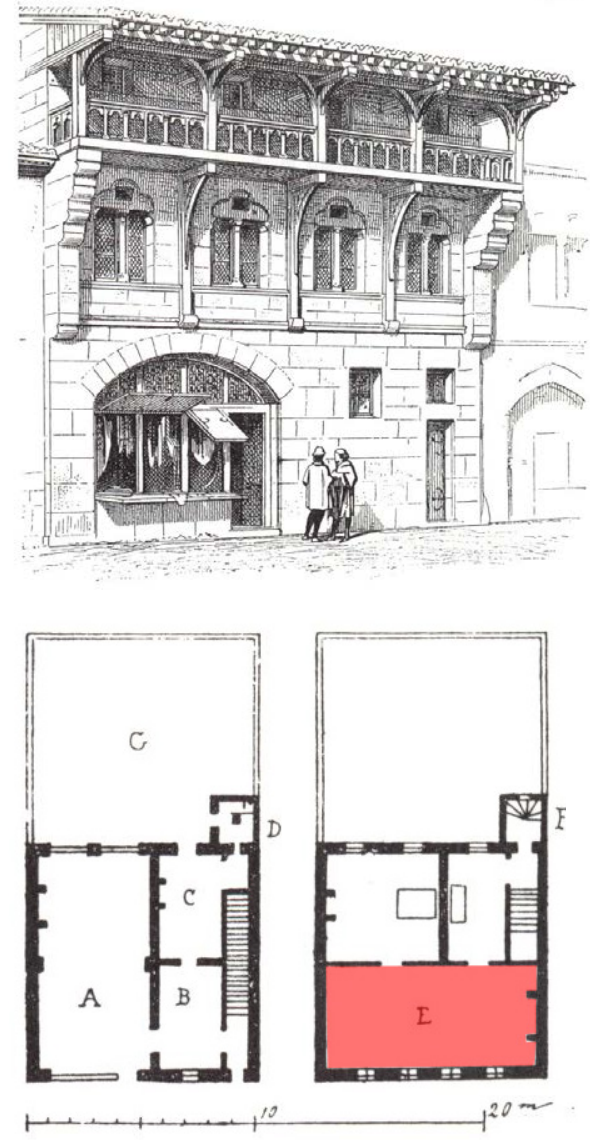

Casa feudal del Dictionnaire Raisonné de l'Architecture
Aunque desde las primeras décadas del siglo XI se produce una evolución en la incipiente pero cada vez más organizada sociedad feudal, no es hasta el siglo XII cuando estos asentamientos rurales experimentan un crecimiento. El aumento de la población, gracias a la mejora de las técnicas en la agricultura, junto a la aparición de una nueva clase social menos guerrera y más refinada, la burquesía son los principales responsables de la formación de las primeras ciudades libres y, consecuentemente, de nuevas actividades urbanas.

De ellas, las poblaciones más próximas a los puertos, como pueden ser los Países Bajos, Flandes o el norte de Italia, son las que experimentan un mayor desarrollo económico al encontrarse próximas a las rutas comerciales $^{52}$

En este contexto, desde principios del siglo XII, y dependiendo de marco geográfico escogido, la fortaleza deja lugar al palacio y el castillo de grandes muros se sustituye por la casa señorial ${ }^{53}$, que conserva una reducida fortificación, pero que en lo esencial es una simple morada.

El espacio multifuncional La casa urbana de origen medieval, donde vive el burgués, es un volumen largo y estrecho, de dos alturas sobre un sótano que es el almacén. Mientras que el piso principal que da a la calle es el lugar de trabajo, tienda o taller, la parte residencial se sitúa en la parte superior Está compuesta por varias piezas no especializadas de gran tamaño. Este hecho, junto a la inexistencia de restaurantes, bares u hoteles, hace que las actividades públicas de recibir, hacer negocios e incluso la de hospedarse se desarrollen en casa, donde puede haber grupos de más de veinte miembros entre familia, empleados, sirvientes, aprendices, amigos y protegidos. No es que no exista intimidad, es que no se conoce. 

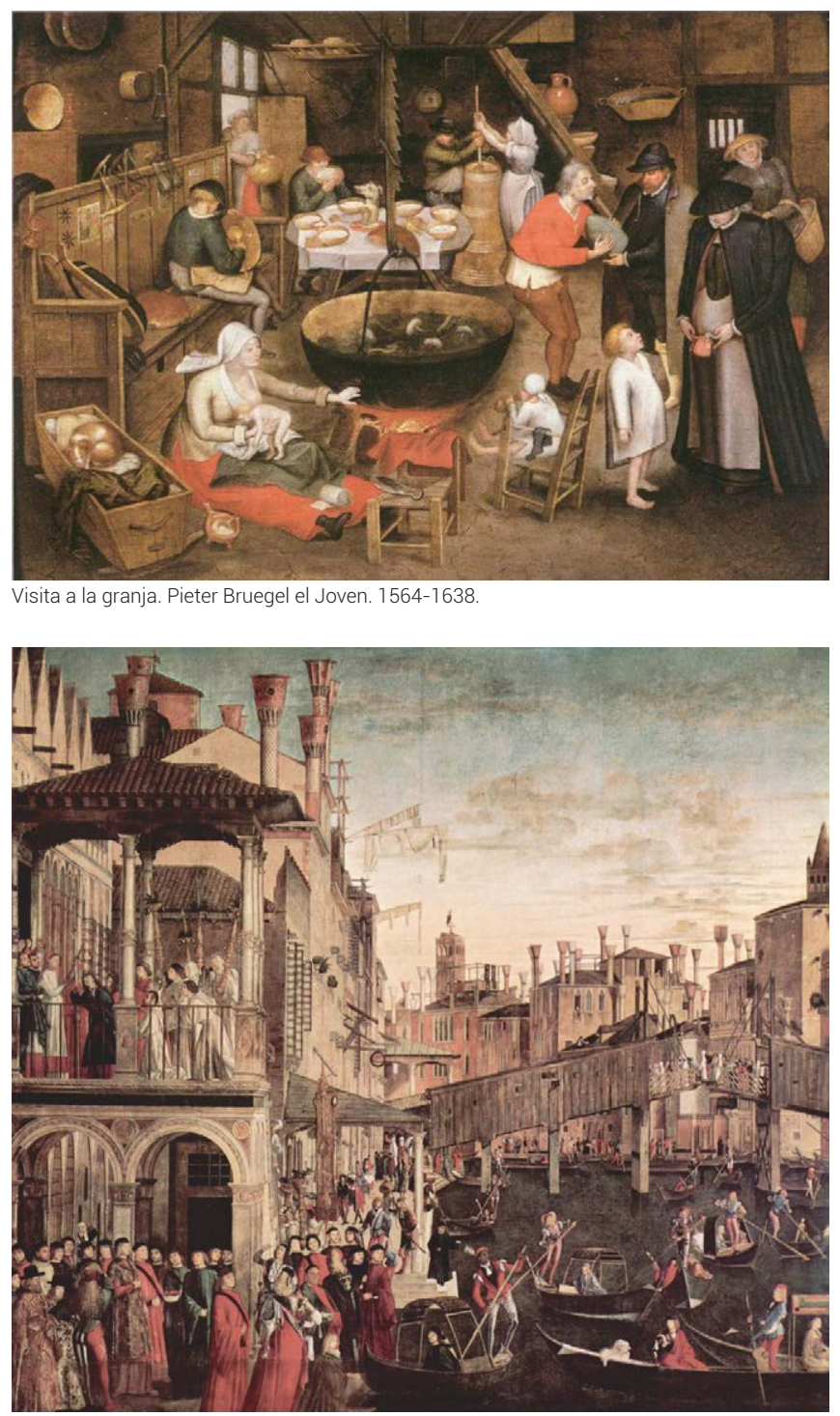

Milagro de la Reliquia de la Cruz. Vittore Carpaccio. 1494
Las chimeneas hacen su aparición en el paisaje urbano.
De este modo, la gente más que vivir en sus casas acampa en ellas ${ }^{54}$ Las actividades de trabajar, recibir invitados o dormir se comparten con la preparación de los alimentos. Un fuego simple, rústico y preparado directamente sobre el suelo con algunos ladrillos como soporte, dispuesto generalmente en el centro del espacio, sirve indistintamente para calentarse, cocinar o secar la ropa. Sin duda una situación que hace pensar que el ambiente de una vivienda medieval debe identificarse con el humo ${ }^{55}$

No es hasta el final de la Edad Media cuando las condiciones espaciales de la vida doméstica cambian ${ }^{56}$. A partir de entonces, y con la mejora de las técnicas constructivas, en las que la piedra sustituye a la madera, las casas son más grandes, aunque tan incómodas como antes. El abaratamiento del vidrio, descubierto en las costas fenicias en el siglo I antes de Cristo y expandido por los romanos, permite que este material se comience a utilizar en las ventanas en lugar de papel engrasado, aunque las ventanas practicables siguen siendo raras.

La difusión de la chimenea

Sin duda la popularización en el siglo $X V^{57}$ de la chimenea doméstica de ladrillo con repisa y tubo de salida adosada al muro es el dispositivo que más transforma la vivienda urbana burguesa, y, sobre todo, los malos humos.

Desde el punto de vista espacial, el uso de la chimenea supone por primera vez en el espacio doméstico el desplazamiento del hogar del lugar central a la pared. Es una tecnología que, poco a poco, adoptan las viviendas, empezando por las más ricas, en busca de un mayor confort.

Aunque gracias a su tiro es posible conducir el humo por convección hacia el exterior ${ }^{58}$, desgraciadamente las primeras chimeneas son técnicamente ineficaces. No están bien diseñadas, los tiros son demasiado grandes y los hogares demasiado profundos. Consecuentemente, y durante muchos siglos, las habitaciones están mal calentadas y llenas de humo.

54 RYBCZYNSKI, Witold. 1986. 38 54 RYBCZYNSKI, Witold. 1986. 38.
55 Esta misma situación se da en las viviendas del popolo medio de las ciudades italianas, que vive por primera vez en casas de ladrillo o piedra con un patio y
un jardín. Por lo general estas viviendas medievales están formadas por dos piezas: la sala principal (sala) que da a la calle, y la alcoba (camera) que vuelca al patio. La cocina es un espacio que, dependiendo de los casos, unas veces se integra en la sala y otras se sitúa en el desván para poder evacuar mejor los humos (ARIES, Philippe y DUBY, Georges. 1987/vol 2. 178).

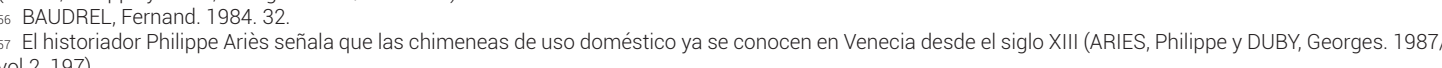

58 Aunque resulte obvio decirlo, la instalación de una chimenea es eso: la introducción en un edificio de un elemento o conducto vertical cuyo tiro tiene que salir necesariamente al exterior por el tejado atravesando de abajo a arriba todas las estancias dispuestas por encima y consecutivamente en el inmueble. 


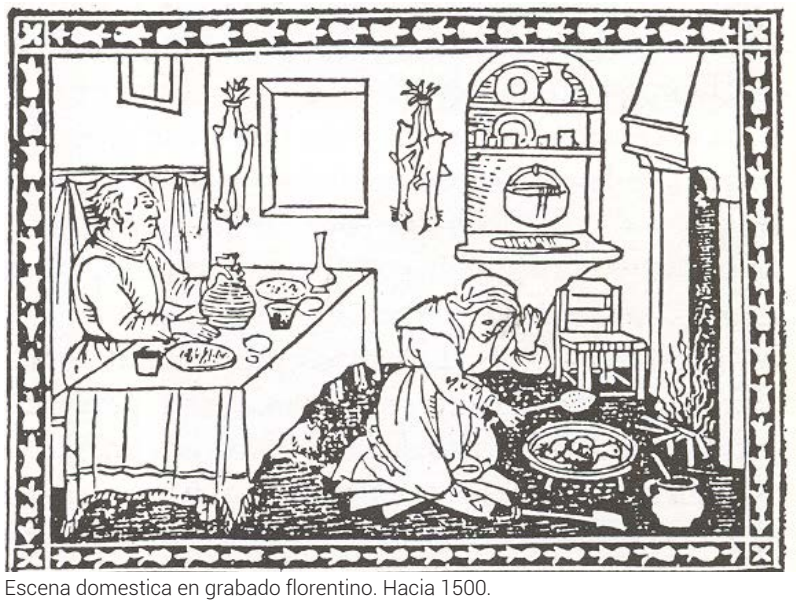

14

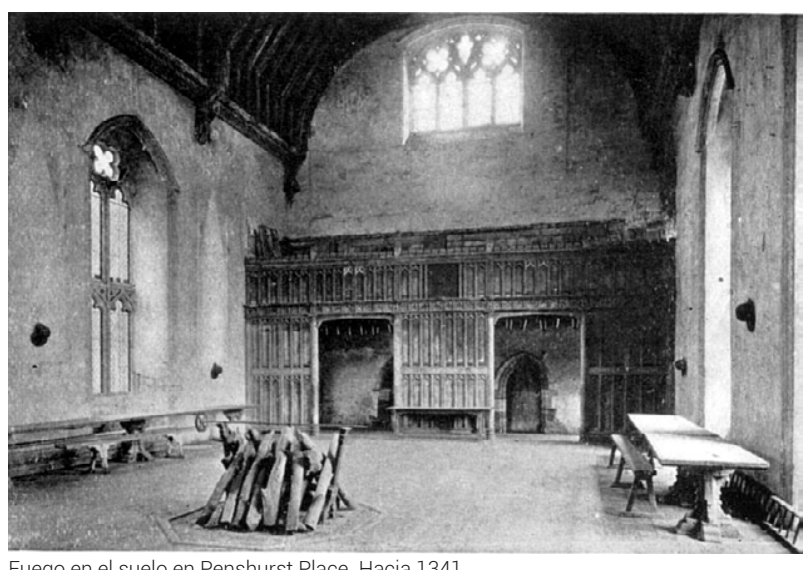

fuego en el suelo en Penshurst Place. Hacia 134

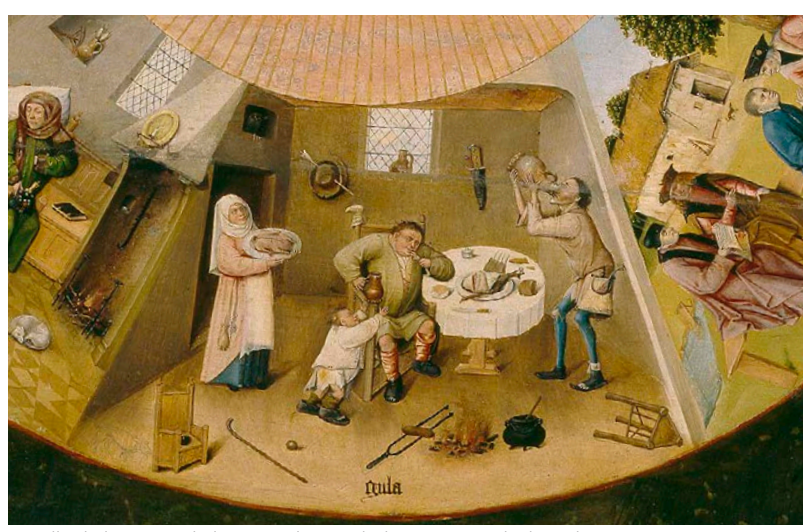

El Bosco. Hacia 1485.
Hay que esperar hasta los siglos XVII y XVIII cuando, gracias a los 'Doctores en humos'59, la chimenea gana en eficacia. Un periodo que coincide con su aumento de tamaño y protagonismo en la vivienda a través de elaborados marcos ornamentales, que la convierten en un claro elemento de representación del espacio doméstico donde el fuego aparece como un factor secundario. Una versión reducida de lo que ha llegado hasta la actualidad.

La habitación de la cocina En un primer momento la chimenea aglutina todas aquellas funciones que antes correspondían al fuego del hogar central: calentar, cocinar e iluminar. Sin embargo, poco a poco la chimenea se convierte en un instrumento de segregación espacial de la casa. El fuego individualizado se fragmenta y se difunde por la casa en un mosaico de fuegos personales ${ }^{60}$, dando lugar a la habitación ${ }^{61} 62$.

Las funciones de calentar y cocinar son las primeras que se disponen en habitaciones independientes con sus correspondientes chimeneas a la francesa ${ }^{63}$ y chimeneas de guisar, respectivamente. 


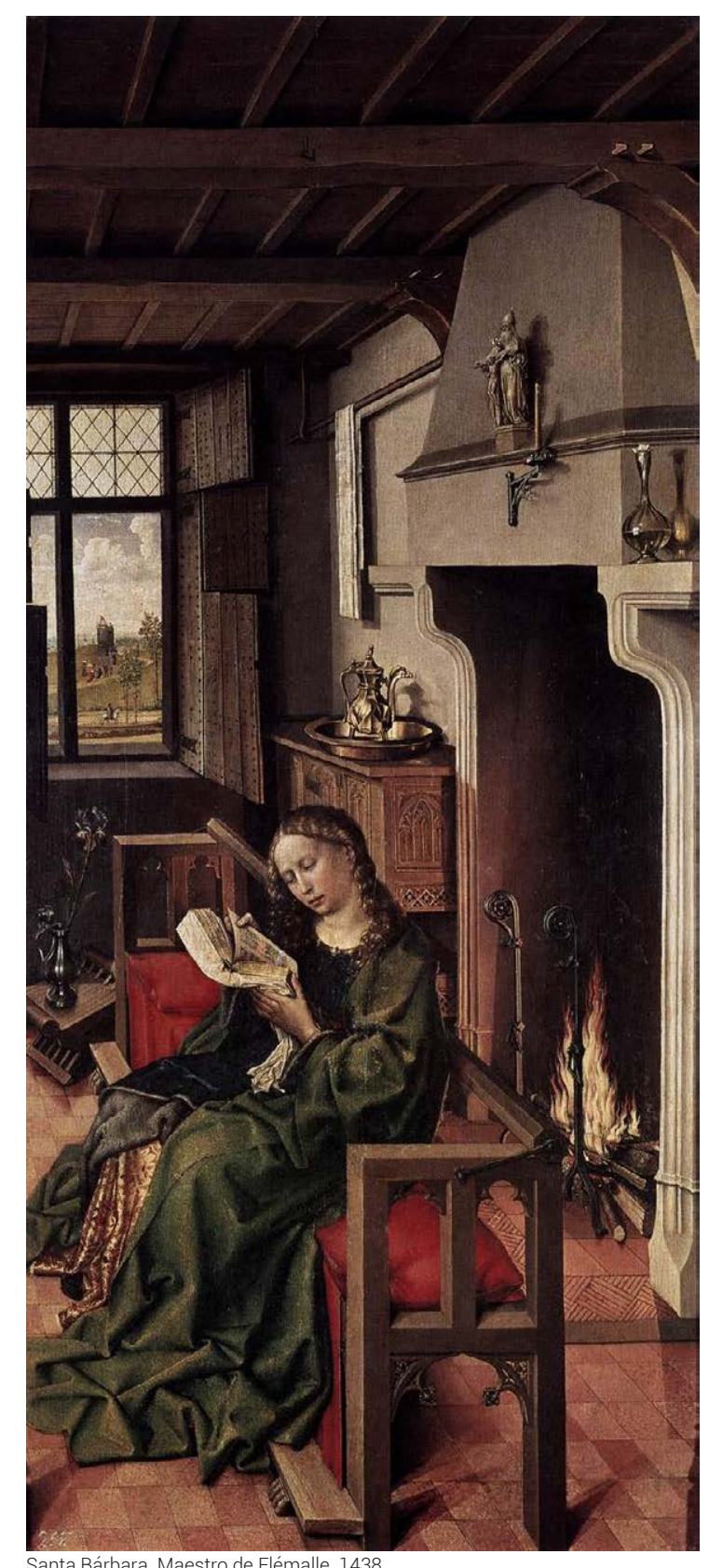

La aparición de la habitación en el siglo XV reorganiza espacialmente la vivienda de la burguesía, que a partir de entonces se compone de varias estancias comunicantes de gran tamaño. Hasta entonces lo habitual es el hecho de que una habitación disponga de varias puertas con acceso a distintos espacios ${ }^{64}$.

Con la multiplicación de las habitaciones ya no existe un único fuego central sino muchos distribuidos. La posibilidad de reproducir y multiplicar cuantitativamente las fuentes de calor en el espacio doméstico significa la progresiva desaparición del valor simbólico del fuego, que sufre una lenta y segura disminución de tal cualidad, perdiendo sus contenidos rituales y míticos ${ }^{65}$.

La chimenea para calentar La chimenea a la francesa, empotrada en el muro con una importante función representativa, se consolida en las salas y dormitorios donde su uso exclusivo es el de calentar. Por el contrario, la chimenea de guisar, más frecuente en los sitios rurales, aparece con una caja autónoma -o adosada al muro- cuyas grandes dimensiones permiten alojar en su interior un 'hogar' o fogón amplio con capacidad suficiente para colocar los artilugios para cocer los alimentos, evacuando los humos a través de una gran campana con su correspondiente cañón ${ }^{66}$.

64 Las habitaciones tienen dos, tres, incluso cuatro puertas, de forma que los trayectos y las actividades provocan numerosas intersecciones. Una planta abierta relativamente permeable a los numerosos miembros de la casa, en donde la compañía es la condición normal y la soledad el estado excepcional. Hasta el final del siglo XVII nadie está solo (ELEB, Monique y DEBARRE, Anne. 1999). 


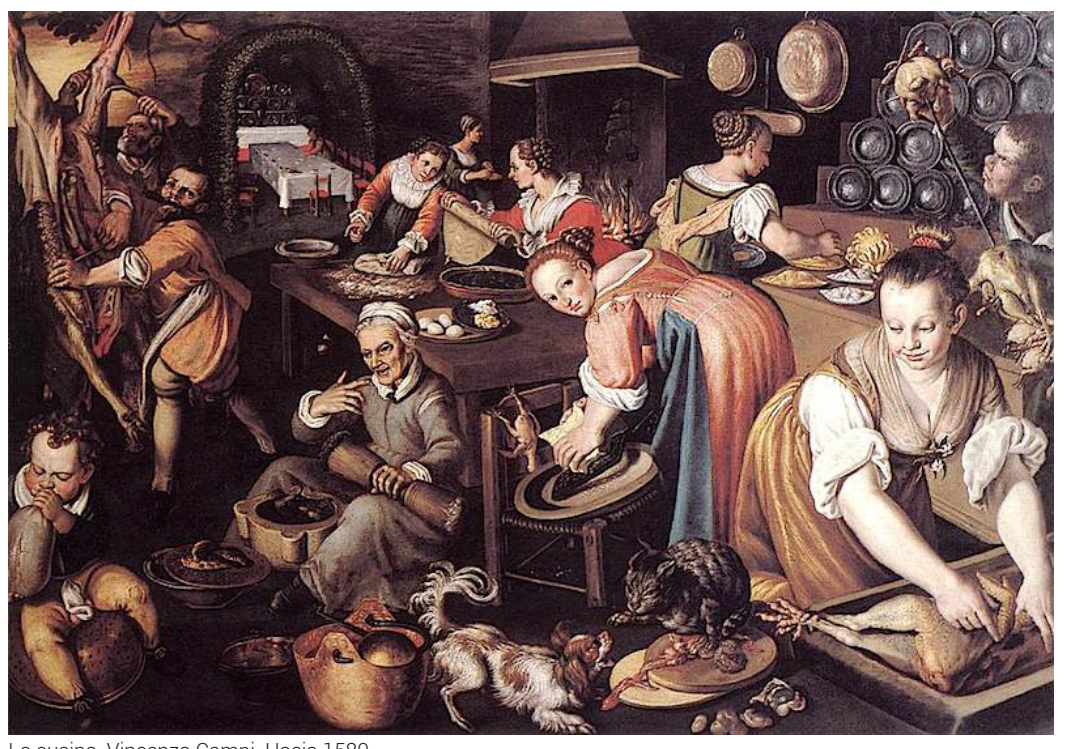

16

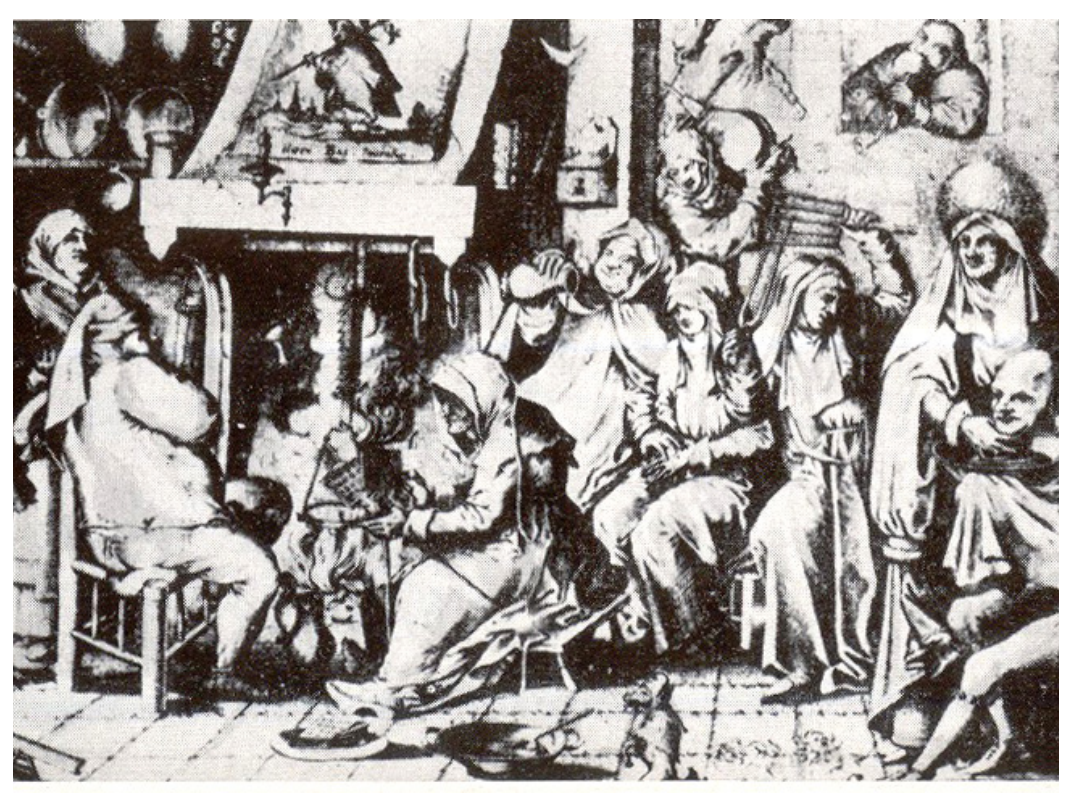

Carnaval en una cocina holandesa. El Bosco. 1567
La chimenea para guisar Sin embargo, el hecho más significativo de la disposición de la chimenea de guisar es la reaparición en el siglo XV de la cocina como pieza independiente dentro de la casa después de casi veinte siglos y tras la culina romana.

La nueva cocina cuenta, en las casas más pudientes, con enormes habitáculos divididos en numerosos anexos, entre los que destacan grandes fuegos abarcados por gigantescas chimeneas rodeadas de colgadores de carnes y morillos para leños ${ }^{67}$. La aportación tecnológica pronto responde a inventos mecánicos, como el espeto asado automatizado que gira automáticamente, impulsado por una hélice, incorporado a la cocina de una residencia en Núremberg en 1485.

A pesar de que la cocina se establece como una habitación aislada, en muchas ocasiones su uso no es exclusivo para cocinar. A veces también se configura como lugar para comer, dormir o simple punto de reunión social de los miembros de la casa.

El brasero Cuando no es posible disponer de una chimenea durante esta época, debido a su alto coste y mantenimiento, o cuando se busca que la chimenea cumpla un papel más simbólico que funcional -calorífico-, las casas recurren al alternativo sistema de braseros que procuran una temperatura confortable en las salas o habitaciones. En cualquier caso, entre las viviendas más ricas, es frecuente que se alternen ambos dispositivos: el calor suave y uniforme del brasero se complementa con la potencia calorífica de la chimenea.

Ya sea a través de la chimenea o del brasero, lo cierto es que estos dos dispositivos suponen un aumento considerable del confort térmico, que permiten por primera vez actividades sedentarias como la lectura 68 .

El nuevo pensamiento La paulatina mejora de las comodidades materiales en el espacio individualista doméstico se corresponde con un nuevo tipo de pensamiento individualista y racionalista que surge en Europa entre los siglos XVI y XVIII y que llega hasta el siglo XX: es el despertar de la conciencia burguesa ${ }^{70}$. 


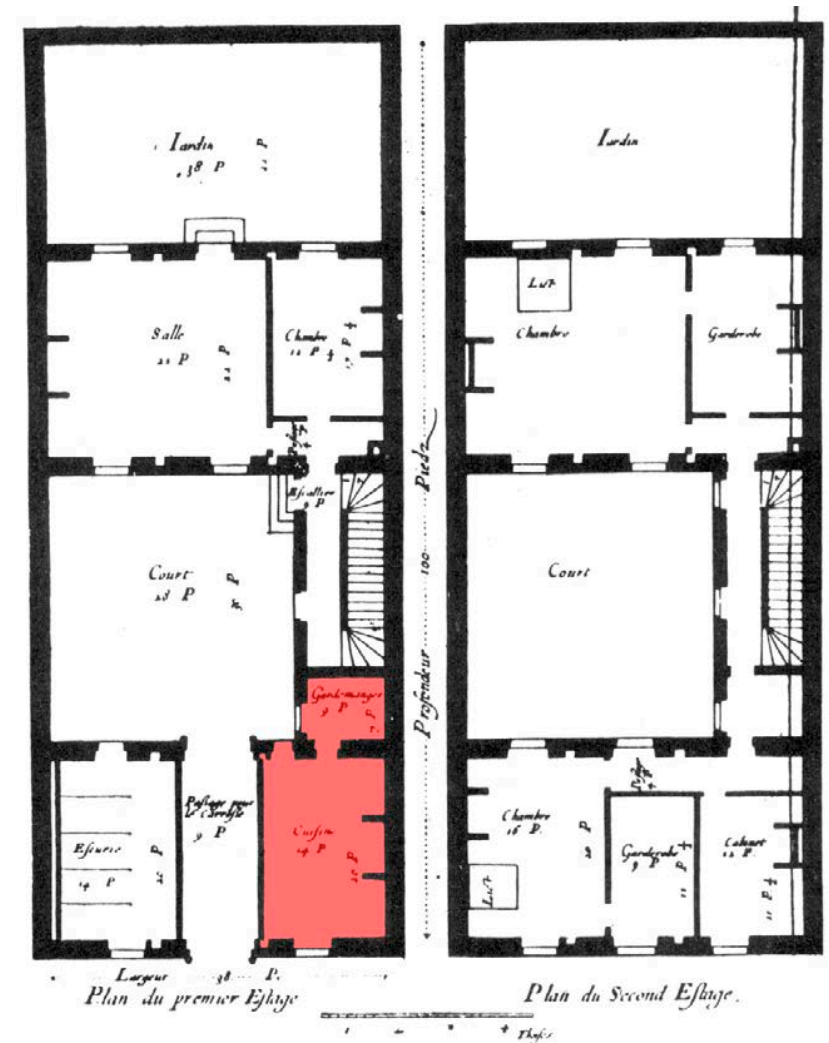

Plantas de una casa burguesa de París en un tratado francés. Hacia 1600
La privatización de la casa La coincidencia al final de la Edad Media de las revoluciones ${ }^{71}$ intelectual, religiosa, moral, política y económica, son las principales responsables de la emergencia moderna del individuo. Junto a este proceso de individualización de la sociedad se operan unos nuevos modos de vida ${ }^{72}$ que se centran en la voluntad de cada individuo de distinguirse de los demás ${ }^{73}$.

Estas nuevas mutaciones sociales no se hacen esperar en el espacio doméstico, en el que a partir de ahora se busca, por encima de todo, preservar la existencia privada. Si hasta el siglo XVII la vivienda está constituida por una serie de espacios polivalentes y la intimidad es algo desconocido, a partir de entonces se busca la individualización y especialización de los espacios en las casas burguesas y aristocráticas. Los tipos de casas de París, la principal ciudad de Europa de 1600, recogen estas transformaciones hacia la individualización.

La típica casa burguesa urbana del siglo XVII sigue ocupando la parcela medieval inicial pero tiene cuatro o cinco pisos. No varía la composición de sus habitantes, ni la diversidad de las actividades que se desarrollan en ella, pero sí la forma de organización y los modos de vida. Ordenada en torno a un patio interior, los pisos bajos contienen un espacio comercial y establos, además de la residencia del propietario y su familia, sus sirvientes y sus empleados. La habitación principal o salle es un espacio grande donde está el hogar central y se utiliza para comer, pasar el rato y recibir visitas ${ }^{74}$. 


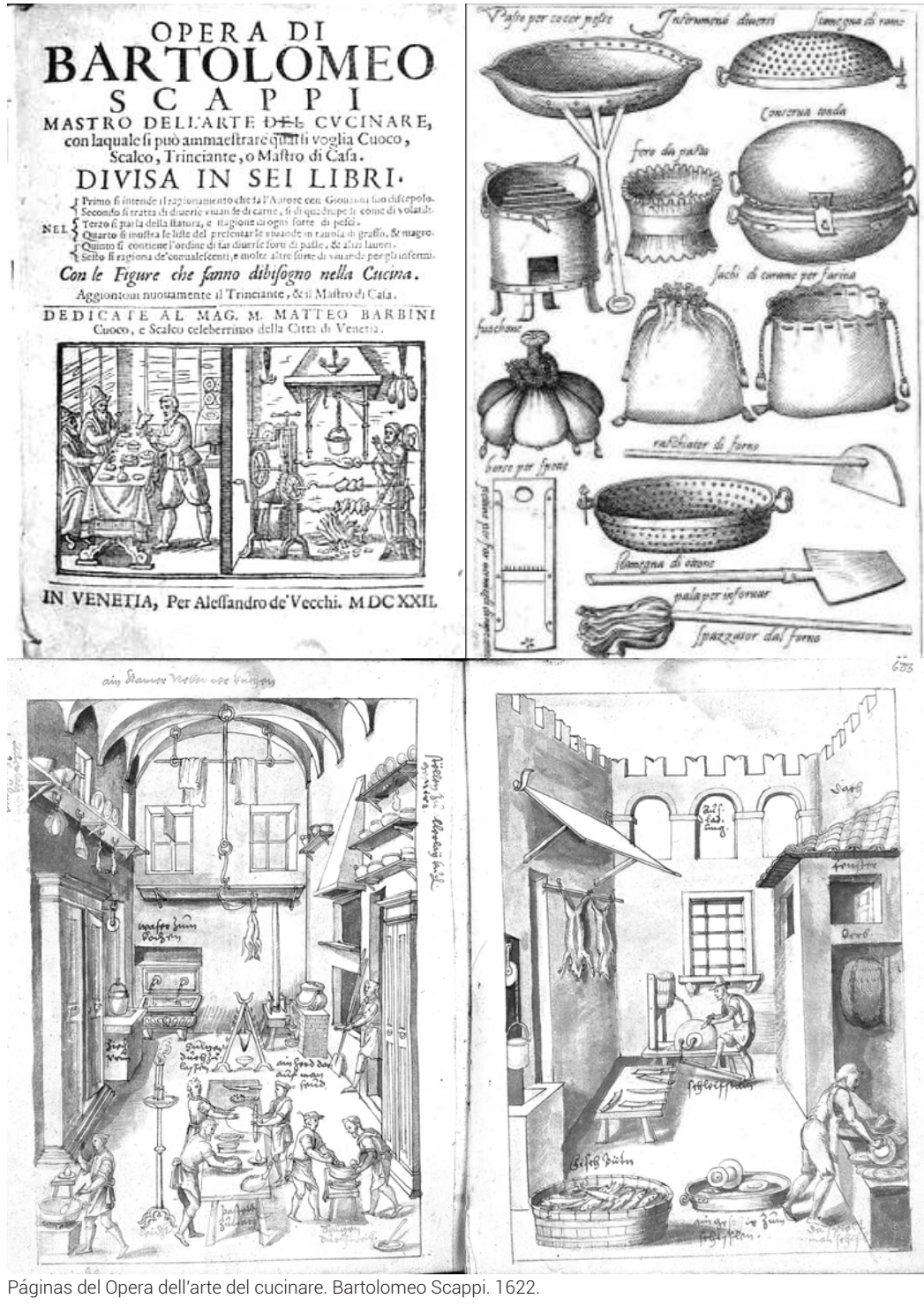

Aunque algunas personas siguen durmiendo en la sala o en camas abatibles, aparece una nueva habitación que se utiliza solo para dormir, la chambre, y otros cuartos secundarios conectados a los principales, como el vestidor ligado al dormitorio y la despensa.

La cocina independiente Si hasta el siglo XVII la preparación de los alimentos, comparte a menudo espacio con otras actividades tales como comer y dormir, entre otras, a partir de entonces, y por primera vez, la cocina pasa a ser únicamente un servicio servidor ${ }^{75}$ que se menosprecia arquitectónica y espacialmente. Relegada a un rincón de la casa, tanto su distribución como su mobiliario depende hasta bien entrado el siglo XIX de simples consideraciones prácticas y funcionales. Mientras que las piezas de la vivienda destinadas a recibir visitas son grandes, exageradamente espaciosas y dan a la calle, la cocina ocupa la menor superficie posible y está orientada hacia el patio interior, que oculta así la visión de la preparación de los alimentos a la vez que se hace inaccesible para las visitas y ventila adecuadamente.

Es posible que los antecedentes de este tipo de cocinas se encuentren en los espacios de preparación de los alimentos de las grandes villas y palacios renacentistas del siglo XVI, cuya transformación responde a una organización de orden social y a la mejora en la técnica culinaria.

Por un lado, el refinamiento del sentido del olfato durante esta época es uno de los motivos por los que las cocinas de estos tipos edificatorios pasan a ocupar los sótanos de las mansiones, implicando una reducción de volumen: se bajan las alturas, prescindiendo de los techos abovedados, con una ventilación mediante ventanas situadas a ras del suelo y una transformación en su distribución que, frente al espacio polivalente, pasa a ser, entre los siglos XVI y XVII, un lugar dividido en varias estancias ${ }^{76}$

Por otro lado, como consecuencia de una revolución culinaria tras la Edad Media, las técnicas de la cocina se transforman por completo ${ }^{77}$. El uso continuado de ciertas maneras de cocción provoca la mejora de ciertos utensilios como las ollas, las marmitas y los pucheros, así como de los espetones, y la preocupación por el mejor aprovechamiento del fuego, aumentando por primera vez el confort en este espacio. 


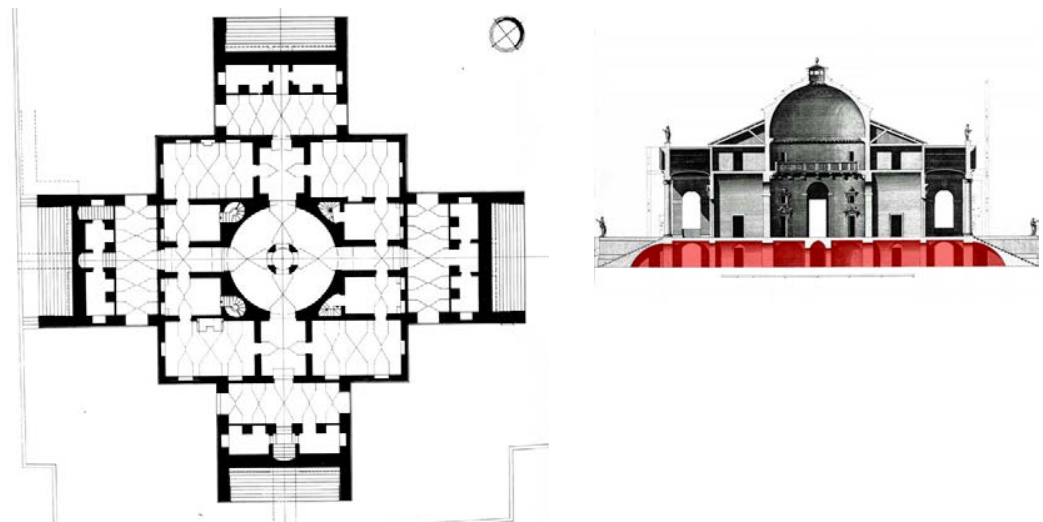

Planta de la cocina y sección de la Villa Rotonda, Vicenza, Italia. Andrea Palladio. 1566 a cocina y sus espacios auxiliares ocupan todo el nivel inferior del edificio bajo la planta principal.

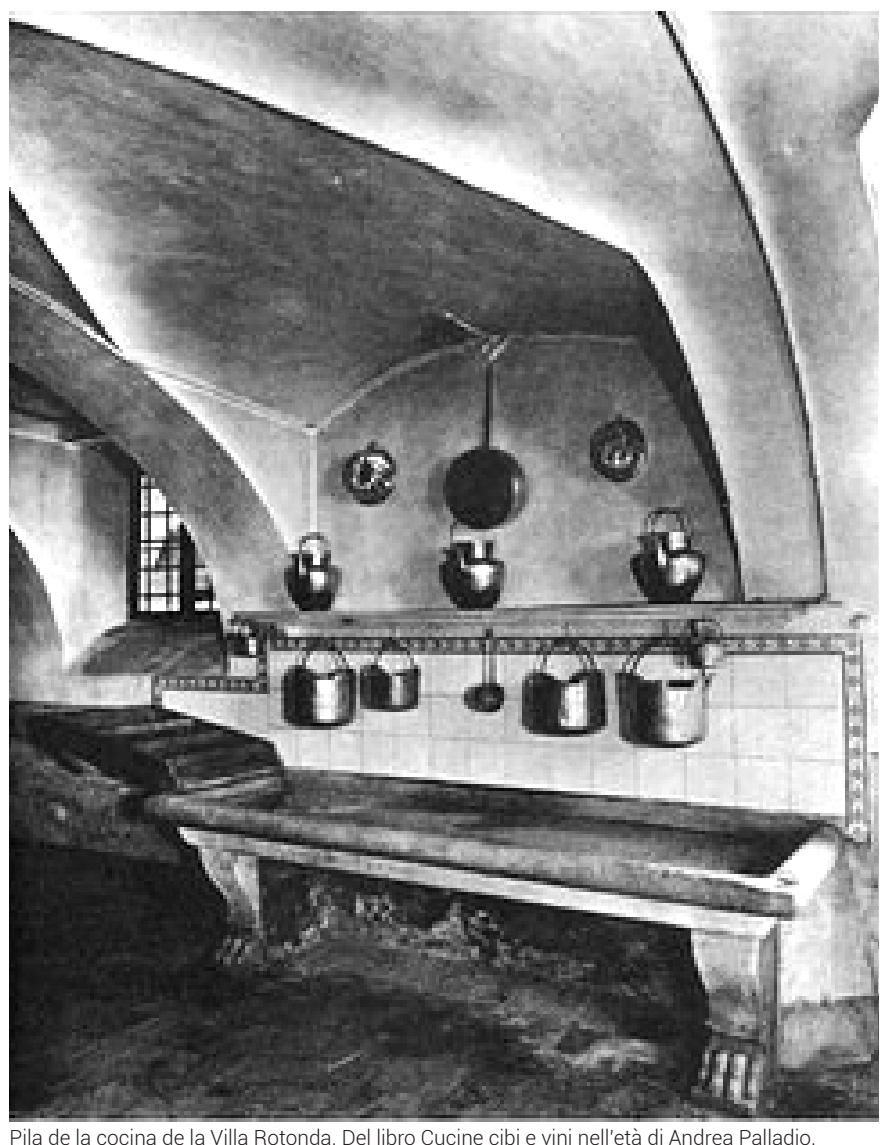

La cocina oculta De este modo, la cocina renacentista se convierte en un espacio aislado y compartimentado. Lo que estructura estas cocinas no es tanto una organización del espacio, que otorga parcelas relacionadas entre sí, comunica funciones afines y separa aquellas incompatibles, como la ocupación necesaria, y en muchos casos indiscriminada, de una sala tras otra sin un estudio global del conjunto

Este es el caso de la Villa Rotonda de Palladio, construida en 1566 a las afueras de la ciudad de Vicenza. Se trata de un tipo de Villa vertical ${ }^{79}$ de la época que se organiza según un sistema estratificado donde la cocina y las zonas de servicio ocupan el piso inferior ${ }^{80}$; a continuación de los espacios nobles se encuentran las habitaciones y, por último, en la parte superior, el almacén de grano. 


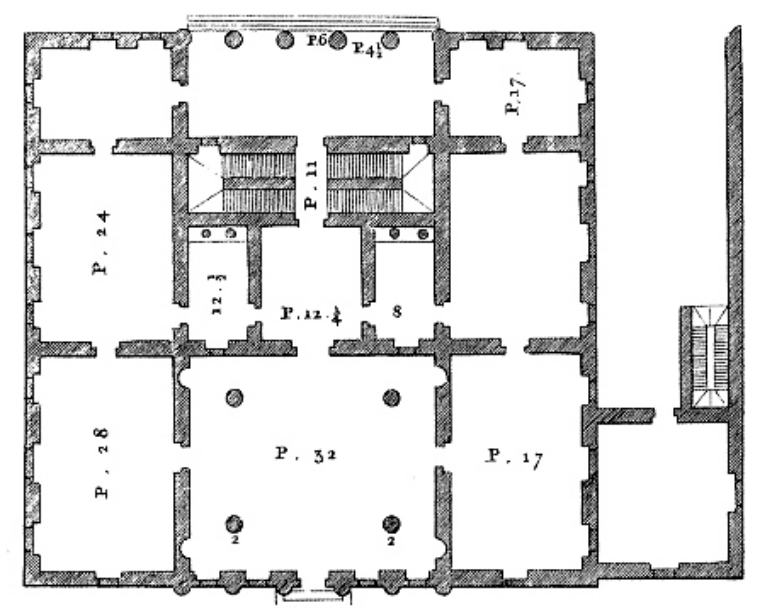

Planta del palacio Antonini, Udine, Italia. Andrea Palladio, 1556

Espacio compartimentado con sucesión de estancias comunicantes.

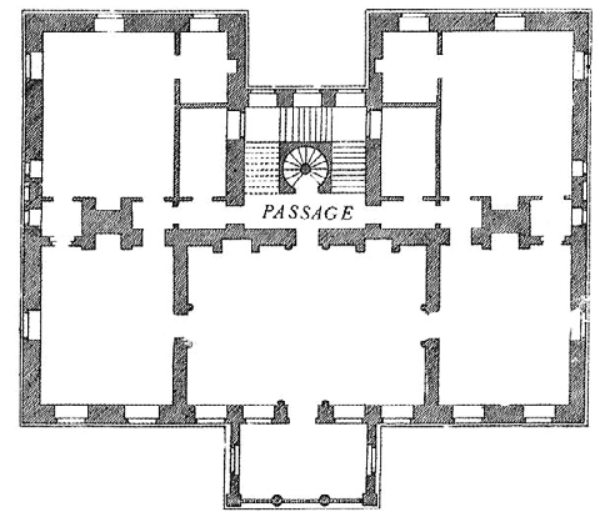

Planta primera de la Amesbury House, Wiltshire. Reino Unido. John Webb,

1667. Aparición de espacios dedicados a la comunicación.
El pasillo distribuidor De vuelta a la cocina de la casa urbana del siglo XVII, su aislamiento se refuerza durante esta época con la popularización del pasillo un elemento que hace su aparición en el siglo XV|81 ${ }^{82}$. Mientras la secuencia de habitaciones comunicantes es apropiada para un tipo de sociedad que se alimenta de la carnalidad, que reconoce al cuerpo como la persona y en la que el gregarismo es habitual, la planta con pasillos es una planta apropiada para una sociedad que considera de mal gusto la carnalidad, que ve el cuerpo como un recipiente de la mente y del espíritu y en la que la privacidad es habitual83. La delimitación de las habitaciones privadas es un proceso que discurre paralelamente a la emergencia social de la individualidad ${ }^{84}$, fomentada por las ciudades y Estados en donde predomina la burguesía ${ }^{85}$.

De este modo, y desde el punto de vista formal, el pasillo elimina el tránsito a través de las habitaciones comunicantes. El edificio compartimentado debe de ser organizado a través del movimiento que lo recorre. Las vías de circulación separan funciones y las unen a través de distribuidores ${ }^{86}$

Bajo un prisma ideológico, este mismo elemento es el que separa la circulación de los sirvientes de la de los señores de la casa: la mezcla de sirvientes y familia, el jaleo de los niños o la charla de las mujeres son inconvenientes accidentales superados por la nueva organización ${ }^{87}$ La relación de las puertas y el pasillo facilita la comunicación y reduce el contacto: la comunicación necesaria se facilita mientras se reduce la accidental; el contacto, de acuerdo con las luces de la razón y los dictados de la moralidad es, para bien, incidental y confuso, y para mal, corruptor y maligno. 


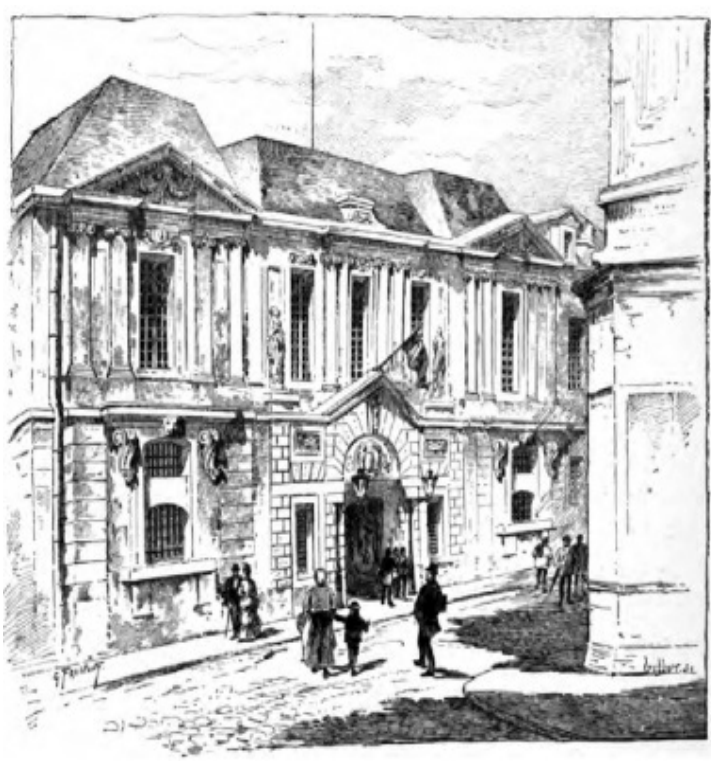

Hôtel francés hacia 1600.
La aparición de Como consecuencia de la nueva organización espacial de la casa, y a la salle à manger la vez que la cocina se consolida como pieza independiente, aparece por primera vez, en 1634, en los Hôtels franceses o palacios ${ }^{88}$, el comedor o salle à manger ${ }^{89}$, una habitación que sustituye a la sala multiusos y que se populariza en el siglo siguiente ${ }^{90}$

Esta progresiva independencia de las zonas de preparación y las de consumo de comida obliga al servicio doméstico a ocupar una parte de la casa a la que asiste, sin interferir en el resto de las estancias, convirtiéndose, ya en el siglo XIX, en una vivienda aparte.

En este contexto de transformaciones, la casa típica se empieza a asemejar a un edificio de apartamentos. La existencia de viviendas de alquiler en los pisos altos supone la separación de la vivienda del trabajo, al haber mucha gente para la que la vivienda es exclusivamente una residencia. La importancia de ser propietario de una casa empieza a ser algo deseado por una gran mayoría. Tener casa propia significa la posibilidad de fundación de un hogar. De esta manera, la búsqueda, lenta, para cada núcleo familiar coincide con la búsqueda de cada uno en la propia casa. La cohabitación con los sirvientes comienza a ser inoportuna. Tanto la reclusión del espacio de la familia ante el exterior como la gradual búsqueda del espacio individual se traducen en nuevos esquemas de distribución y en nuevos usos de los espacios de la casa.

Sin embargo, la privacidad de la casa aparece de forma inconsciente ligada a las innovaciones tecnológicas y fundamentalmente a la evolución de las relaciones humanas y al cambio de concepto de sociabilidad.

Para formar en la conciencia humana la idea de la casa como espacio de la vida familiar hace falta la experiencia de lo privado y lo íntimo, sensaciones ambas imposibles en la sala medieval. 
La estufa Desde un punto de vista tecnológico, el uso de las estufas, un elemento procedente de Alemania que encierra y oculta la visión de la llama y que es mucho más eficaz que la chimenea, se generaliza en el siglo $\mathrm{XVIII}{ }^{91}$. Parece un elemento doméstico importante que favorece la privacidad. Su uso hace posible la subdivisión de la casa en muchas piezas a las que se van asignando funciones especializadas ${ }^{92}$.

En cualquier caso, la aparición de la intimidad en la casa no se produce tanto por las innovaciones técnicas como por una evolución en las relaciones humanas como la aparición de la pareja que quiere cuidar a sus hijos y vivir con ellos como grupo reducido, lo que lleva a una organización distinta del espacio doméstico.

A la vez que se desarrolla la casa burquesa en Francia, en Holanda tiene lugar la evolución de un tipo especial de vivienda que sin duda marca un futuro del espacio doméstico en Europa que perdura hasta nuestros días.

La casa holandesa Las Provincias Unidas de los Países Bajos son un Estado totalmente

del s. XVII nuevo, donde las ciudades manufactureras de uno de los países más pequeños de Europa crecen a tal velocidad que a mediados del siglo XVII se convierte en la principal nación industrial del mundo. Los holandeses, ciudadanos por tradición histórica, son burqueses por inclinación. Bajo la influencia de la religión calvinista, la vida cotidiana en los Países Bajos en el siglo XVII representa las virtudes burquesas tradicionales: una moderación sosegada, una admiración por el trabajo intenso y una prudencia financiera ${ }^{93}$. En este sentido su modo de vida nada tiene que ver con las pretenciosas casas burquesas de París o de Londres.
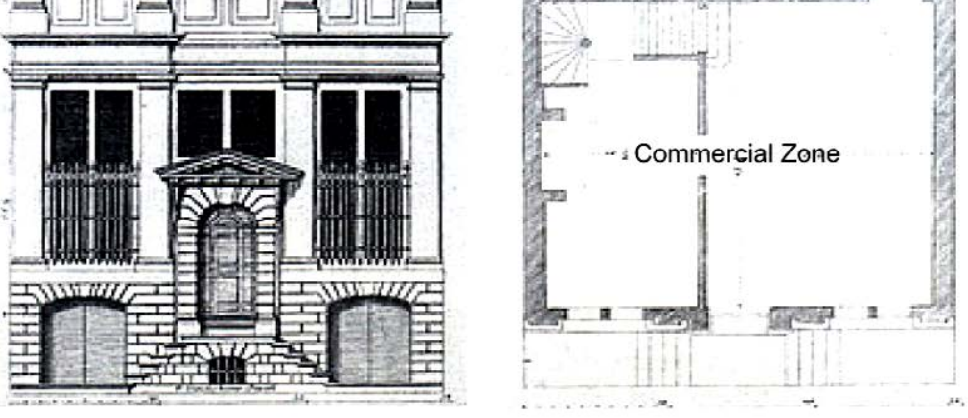

. Philip Vingboons, 1639 

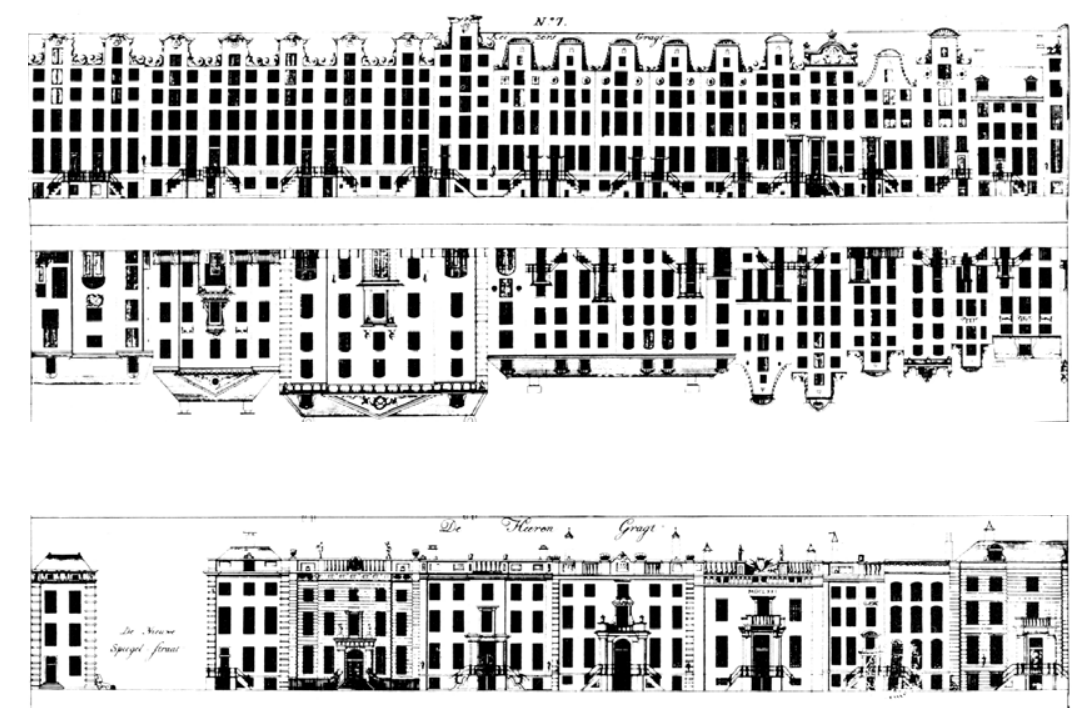

\section{.}

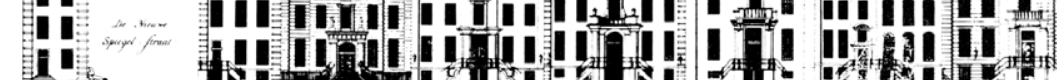

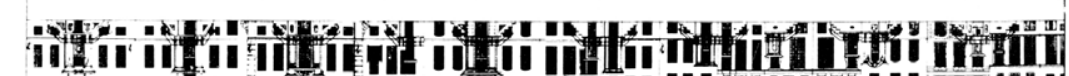

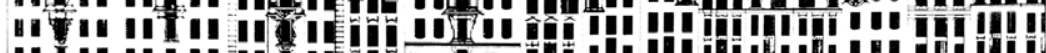

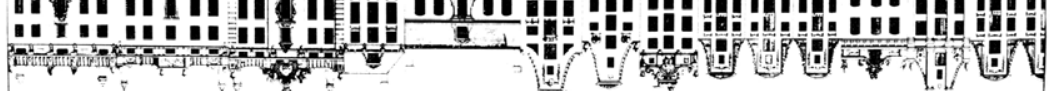

Grabado con los alzados de las fachadas a lo largo de un canal de Amsterdam. Hacia 1700
Otro factor de índole técnica determina la configuración de sus viviendas: la dificultad de construir sobre los canales establece una reducción de la fachada que mira a la calle, dando como resultado unas parcelas muy alargadas y estrechas. El interior se organiza mediante una habitación delantera donde se realizan las actividades comerciales, y una habitación trasera donde se cocina y se duerme. A pesar de que estas habitaciones no tienen funciones especializadas, a mediados de siglo se inicia la subdivisión de la casa según usos diurnos y nocturnos.

Como las paredes laterales son las que soportan todo el peso del tejado, las dos fachadas de la vivienda se liberan, posibilitando la construcción de grandes ventanas que permiten entrar la luz a toda la casa. Esta luz se controla con un elemento nuevo: el visillo, que, además, permite mantener la intimidad frente a la calle. 


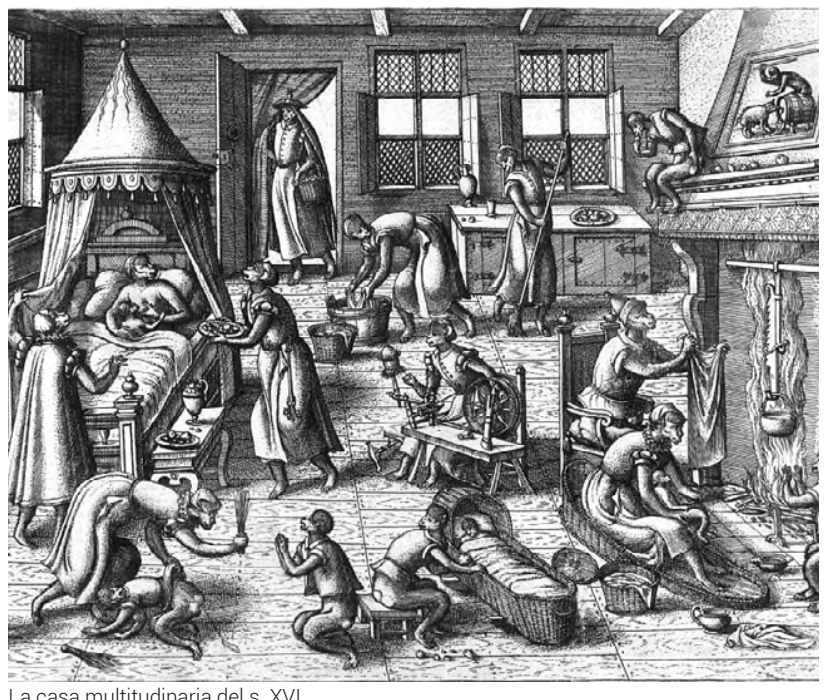

La casa multitudinaria del s. XVI

24

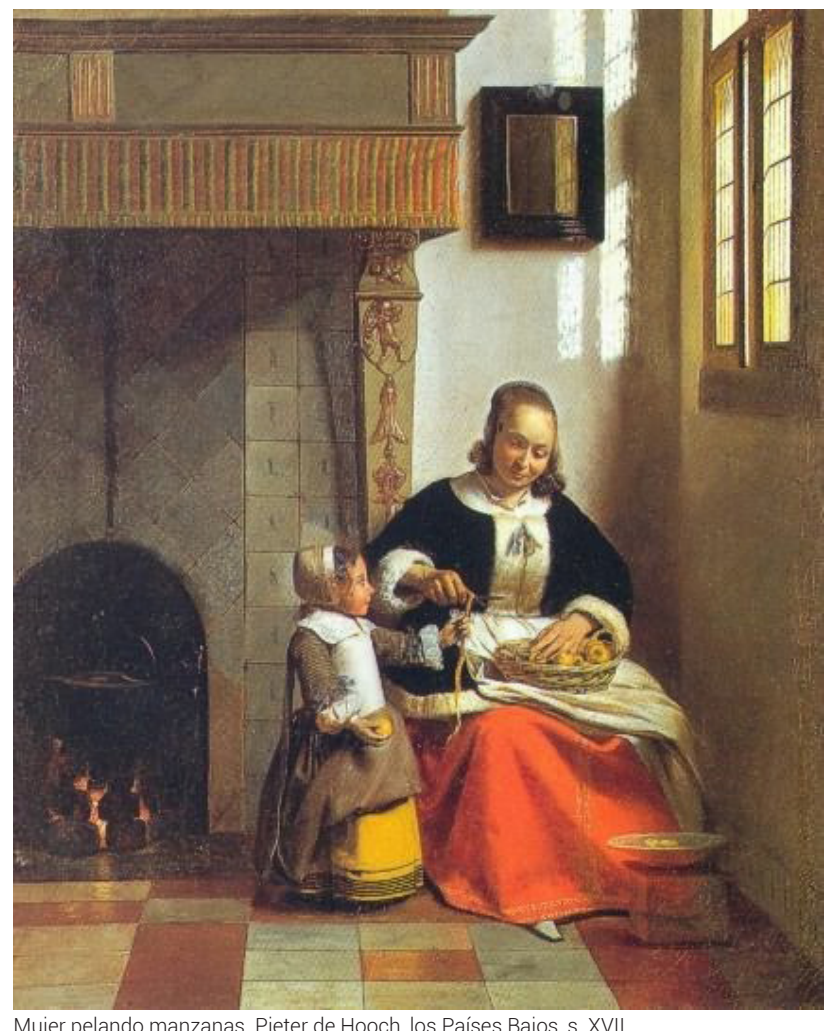

La casa como el espacio de Lo importante de esta situación arquitectónica es que estas casas la vida familiar son 'casas pequeñas' que alojan a un promedio de cuatro o cinco personas, frente a las veinticinco personas de las viviendas de París, donde no hay inquilinos ${ }^{94}$. Los holandeses prefieren ser los dueños de sus casas por pequeñas que sean ${ }^{95}$.

Anteriormente, a mediados del siglo XVI, las monarquías de Europa Occidental han dibujado una primera aproximación a la concepción de la familia; a pesar de que el catolicismo del Concilio de Trento (1545-

1563) considera el matrimonio como una jurisdicción eclesiástica y el reformismo luterano como una jurisdicción civil, ambos coinciden en la necesidad de regularlo estableciendo como base tanto la libre voluntad de los contrayentes como la prohibición de la imposición paterna.

A partir de entonces, el matrimonio se desliga de los intereses de los linajes y pasa a ser controlado por el reino, definiéndose desde el Estado como un instrumento para garantizar el orden social ${ }^{96}$. Con estas transformaciones físicas y afectivas la vivienda pasa de ser refugio a lugar de protección contra los intrusos, lo que da lugar a una nueva unidad social compacta, la familia97

Con la reducción de la vivienda, determinadas actividades como el trabajo salen del hogar, construyéndose establecimientos separados para los negocios. Tampoco hay casi sirvientes, pues la sociedad holandesa desalienta su contratación estableciendo impuestos especiales para aquellos que emplean sus servicios ${ }^{98}$ La independencia individual se aprecia más que en otras partes y el carácter público de 'casa grande' se ve sustituido por una vida hogareña y más privada. 


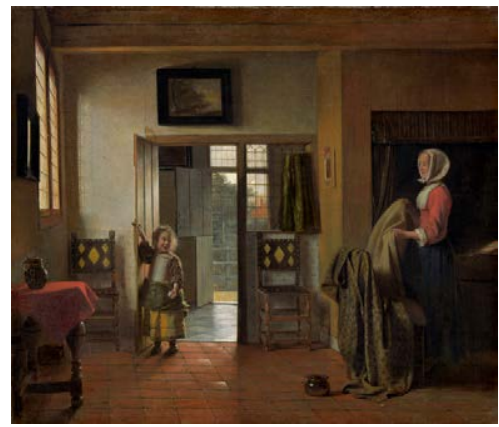

El dormitorio.

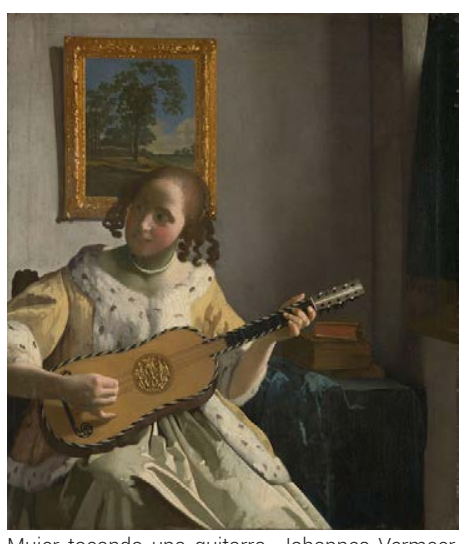

Mujer tocando una gutart
los Paises Bajos, $1670-72$.
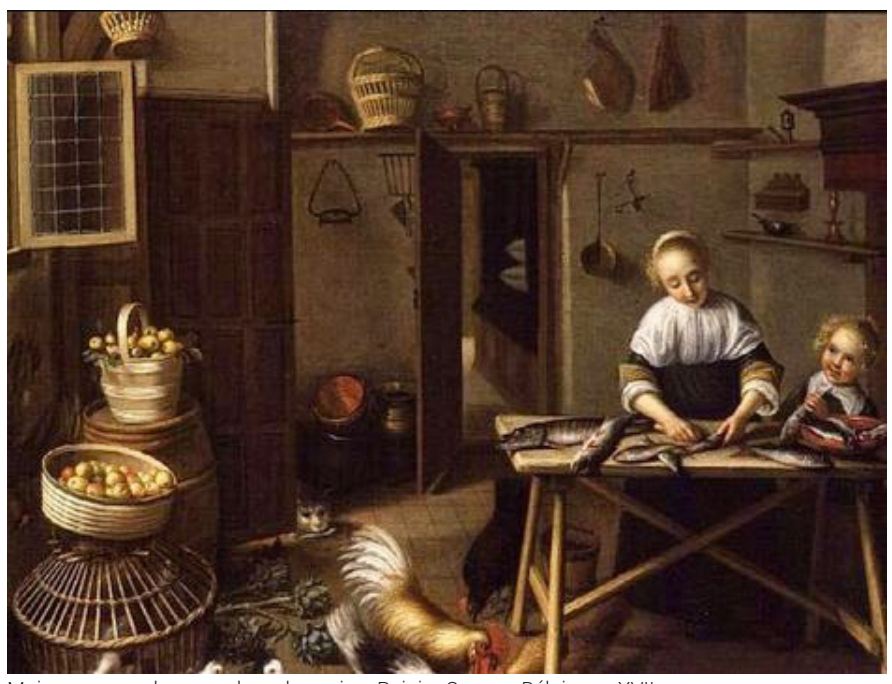

Mujer preparando pescado en la cocina. Reinier Coveyn, Bélgica, s. XVII.

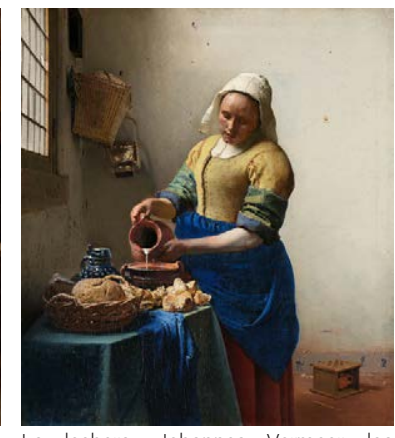

La lechera. Johannes
Paises Bajos, $1657-1658$

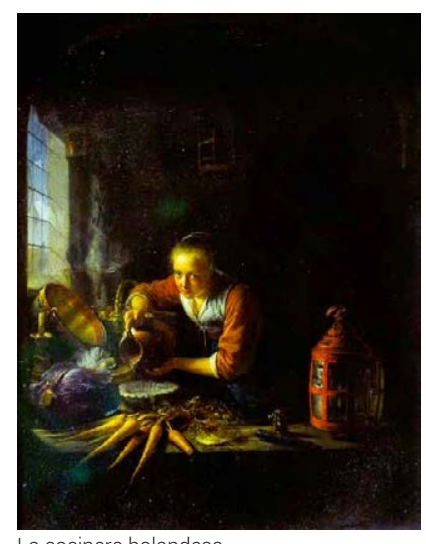

Gerrit Dou, los Paises Bajos, 1650.
Con la familia llega el aislamiento en la vivienda, pero también la aparición de la vida familiar y, por tanto, de una nueva domesticidad. La ausencia de criados provoca que la funcionalidad comience a cobrar un papel protagonista en la planificación y estructuración de espacio doméstico moderno, apareciendo los conceptos de confort e intimidad y la definición del rol de la mujer asociado al recién inventado trabajo doméstico.

La intimidad La sensación de intimidad que crea una habitación y sus elementos, cuya consecuencia es la necesidad de que en la vivienda aparezcan lugares 'neutros' o lugares de encuentro, es la que el historiador Mario Pratz llama Stimmung ${ }^{99}$ - término alemán que significa atmósfera-. Es la transición de la casa pública feudal a la casa particular familiar.

Desde ahora las mujeres son las que, además de criar a los hijos, e independientemente de su posición social, se encargan de la mayor parte de las tareas domésticas y por tanto de la administración absoluta de toda su casa ${ }^{100}$. Se busca que la casa sea, sobre todo, confortable.

La domesticidad La feminización de la casa en los Países Bajos del siglo XVII, representada por pintores como Johannes Vermeer o Pieter De Hooch, es uno de los acontecimientos más importantes en la historia de la evolución del espacio doméstico occidental. En este sentido, la cocina de la vivienda holandesa del siglo XVII, a diferencia de la cocina de las casa burguesa de París -que ocupa una habitación frente al patio- o la de los barrios residenciales ingleses que se encuentra en los sótanos ${ }^{101}$, se convierte en la habitación más importante de la vivienda, algo intermedio entre un templo y un museo al cuidado de la mujer ${ }^{102}$ 
El almacenaje en la cocina: Por primera vez se toma conciencia de una casa y de una cocina el aparador construida por y para la mujer ${ }^{103}$, que se refleja tanto en la organización de los utensilios como en la cantidad y calidad de los objetos disponibles en este espacio. Entre las equipaciones no solo se encuentra el hogar y la bomba de agua, sino también una serie de artículos e instrumentos. Entre ellos el aparador, importado de Alemania, que se convierte en el mueble burgués más importante sustituyendo al arca horizontal medieval como sitio donde guardar cosas $^{104} 105$

La difusión durante el siglo XVIII del modelo y el concepto de casa holandesa al resto de países europeos como Inglaterra, Francia y los Estados Alemanes, coincide con la mejora de las condiciones de confort de los interiores domésticos. En este sentido, las investigaciones llevadas a cabo durante esta época por alquimistas, químicos y artilleros en el campo de la combustión y de su rendimiento son decisivos para mejorar la ineficaz y mefítica chimenea, sin duda uno de los elementos del espacio doméstico que mayor confort pueden ofrecer.

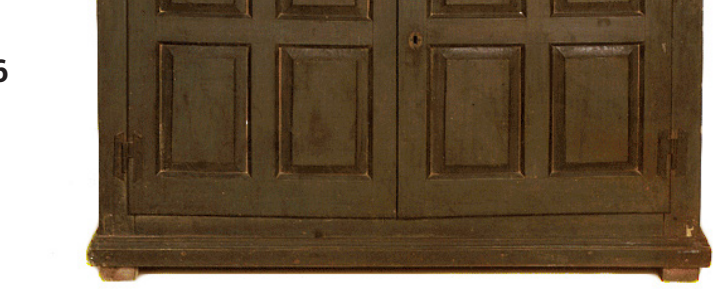

Aparador holandés, s. XVII.

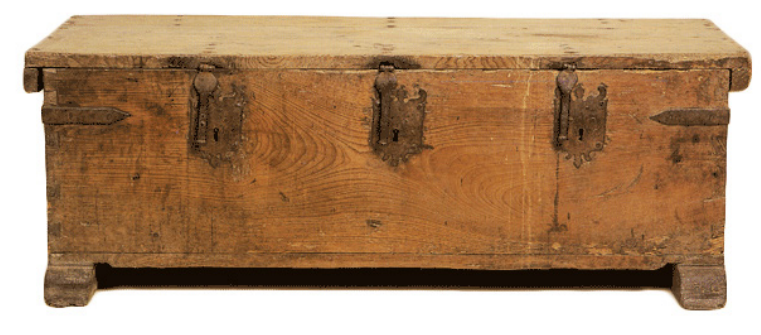

Arca horizontal medieval. 

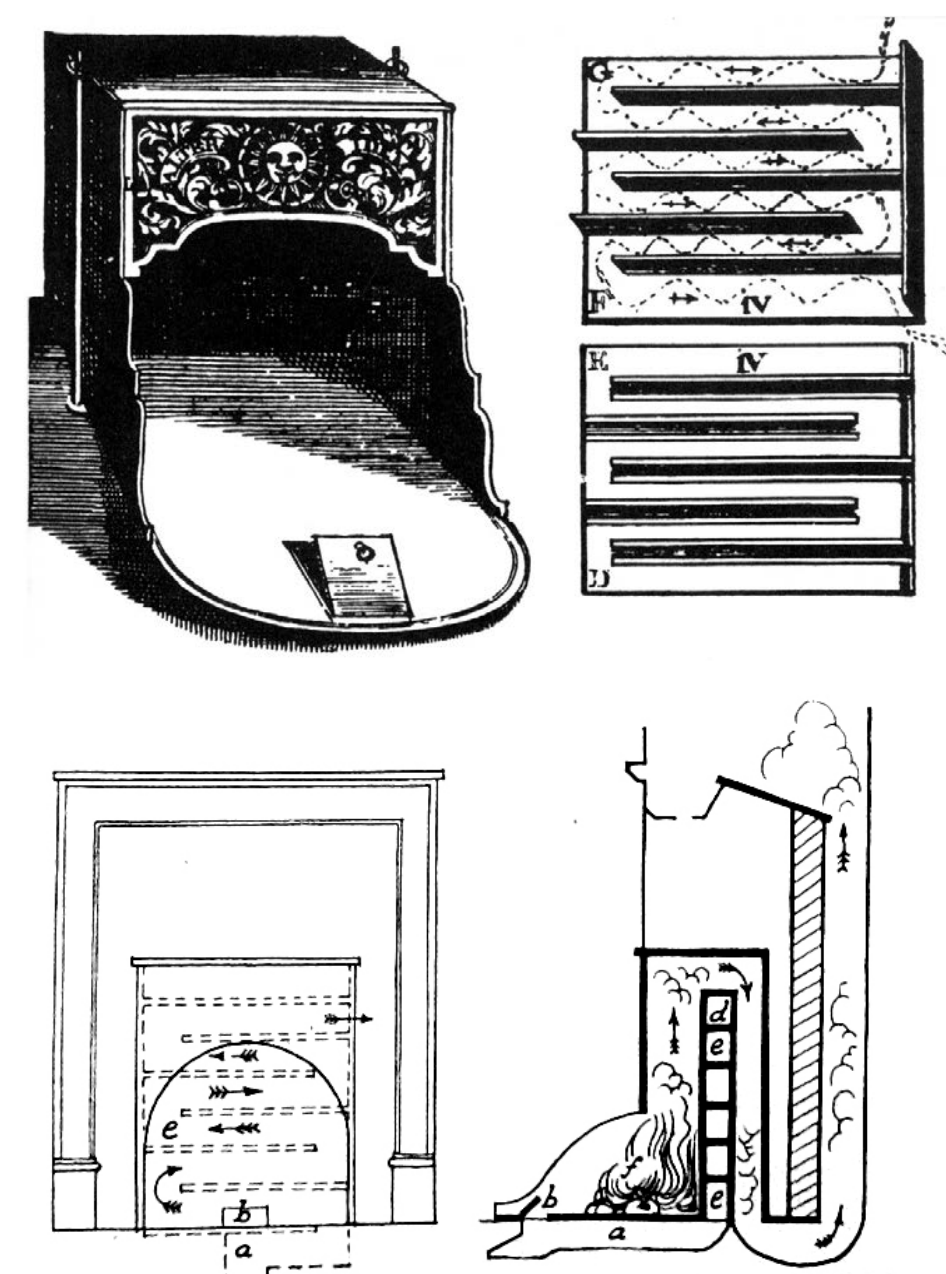

El Hogar Pensilvania de Benjamin Franklin, 1745. El aire entra por b, pasa por el conducto a, circula por los caliductos e, y sale a la habitación por d.
La estufa Franklin Destaca en particular el modelo de estufa desarrollado por Benjamin Franklin en 1772, que se coloca en el hogar o chimenea para la utilización de los gases de combustión no eliminados. Basada en modelos alemanes como la estufa holandesa de Pennsylvania106 la estufa Franklin o salamandra es el primer sistema de calefacción moderna no integrado en la construcción, que permite una mejor regulación de la combustión y un mejor control del humo que el tradicional hogar, implicando un ahorro de combustible $e^{107}$

La cocina de varios fogones

Son precisamente estos intentos de perfeccionar algunos de los aspectos del utillaje de combustión doméstica de Franklin lo que lleva al polifacético Benjamin Thomson, más conocido como Conde von Rumford, a dar en 1797 los primeros pasos para la sustitución del fuego abierto por una zona de cocción compuesta por varios fogones. Rumford busca aplicar un razonamiento científico a un aspecto de la vida doméstica, mejorando los métodos de combustión en cocinas y hogares domésticos

Dentro del marco de la Revolución Francesa y sus ideales de fraternidad, igualdad y libertad, Rumford se obsesiona con encontrar la manera de alimentar de la forma más económica posible a los soldados y a la gente más pobre. Esta reflexión le conduce a proponer un estudio sobre la economía de la preparación de los alimentos que a la vez que cocinar con precisión permite disminuir riesgos de quemaduras. Para ello divide el problema en el tipo de combustible y el tipo de hogar en el que quemar ese combustible. 


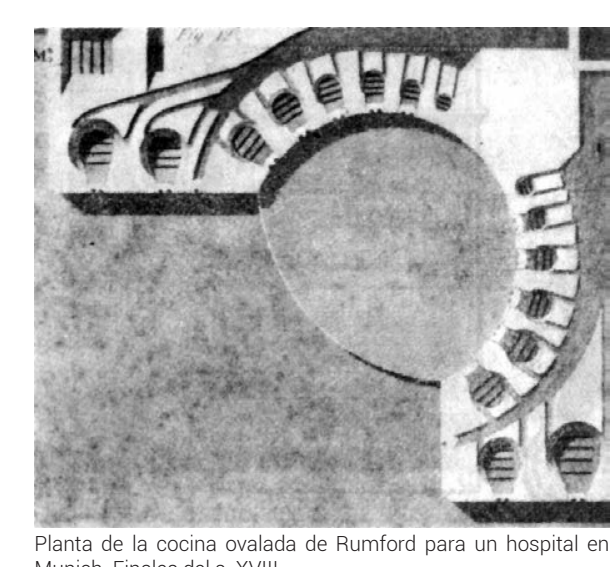

Planta de la cocina ovalada
Munich. Finales del s. XVIII.

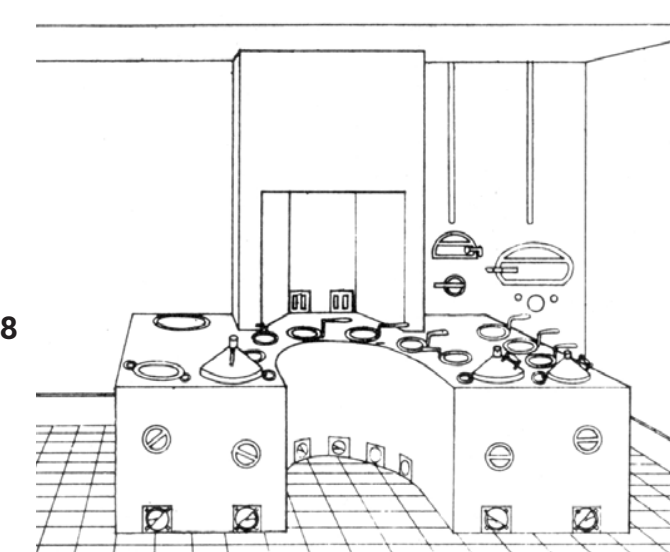

Modelo de cocina de Rumford hacia 1800

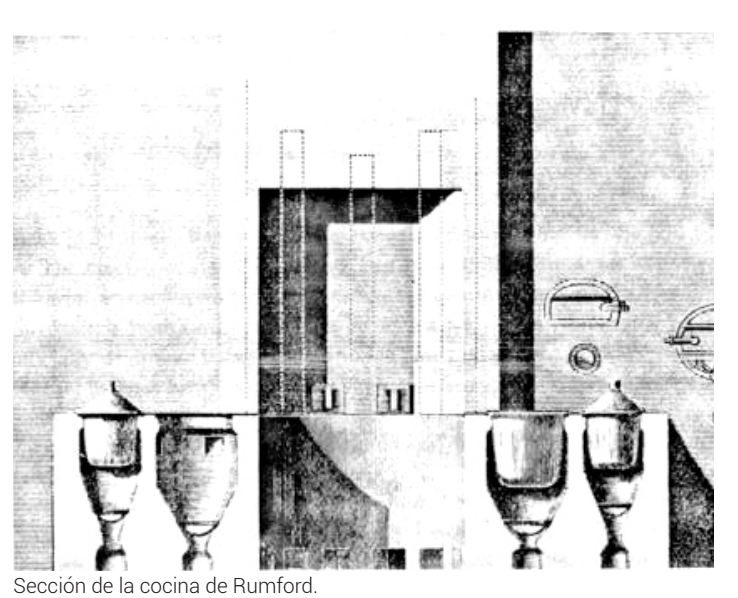

La cocina Rumford Tras diversos experimentos culinarios ${ }^{108}$ finalmente Rumford presenta la cocina económica. Muy parecida formalmente a la tabernae romana, la cocina consiste en una estructura maciza de ladrillo en forma de $U$ en cuya parte superior plana hay instaladas un gran número de diferentes cámaras de combustión cerradas que a su vez constan de una parrilla, una caja para las cenizas y un portillo para regular el tiro. Esta estructura posibilita la reducción del hogar al menor espacio posible -fuente calorífica compacta, como caja aislada que anticipa lo que es la cocina moderna.

Sin embargo, lo novedoso de la cocina de Rumford es la domesticación de la llama ${ }^{109}$. A la capacidad de producir y mantener el fuego se le une, en el siglo XVIII, la posibilidad por primera vez de controlarlo: no producir calor más que cuando éste sea necesario y en la intensidad adecuada. De una manera eficiente, esta cocina por primera vez produce el calor que se necesita para preparar los alimentos a la vez que el cocinero vigila los fuegos desde el centro, desde donde apenas se mueve ${ }^{110}$

Este adelanto no solo supone una revolución en las técnicas y en los procesos culinarios, que se vuelven más complejos, permitiendo realizar nuevas y diferentes recetas, sino también en el espacio de la cocina, que se economiza permitiendo un nuevo orden y una distribución más cómoda.

Las cocinas de Rumford nunca llegan a popularizarse. A pesar de que dan el paso definitivo al perfeccionamiento del fogón de cocina a finales del siglo XVIII, la falta de tecnología provoca que no sea hasta el periodo entre 1830 y 1880 cuando sus ideas sobre la concentración de la fuente de calor se pongan en práctica y se difundan, primero en América y más tarde en Europa, a través de la cocina de hierro calentada por madera o carbón con un cajón para las cenizas ${ }^{111}$.

108 Rumford es el responsable de modernizar el ejército de Baviera, convirtiéndolo en fuerzas de policía. Gracias a ellas, un día planea una redada en la que detiene a 2600 mendigos y vagabundos de Munich. Además de alojarl os y darles trabajo, tambien los alimenta. Interesado en la intendencia militar a gran escala, (

Este experimento no solo supone uno de los primeros trabajos en la nutrición científica, sino también en el ahorro de combustible, ya que Rumford consigue Otros inventos de Rumford son el diseño de hornos pequeños para familias pobres y un horno de cocina portátil con un hogar colgante en el que el calor es canalizado alrededor de la olla. Es el predecesor de las actuales cocinas economicas de combustible solido (WRIGHT LAWRENCE. Op. cit. 134). 

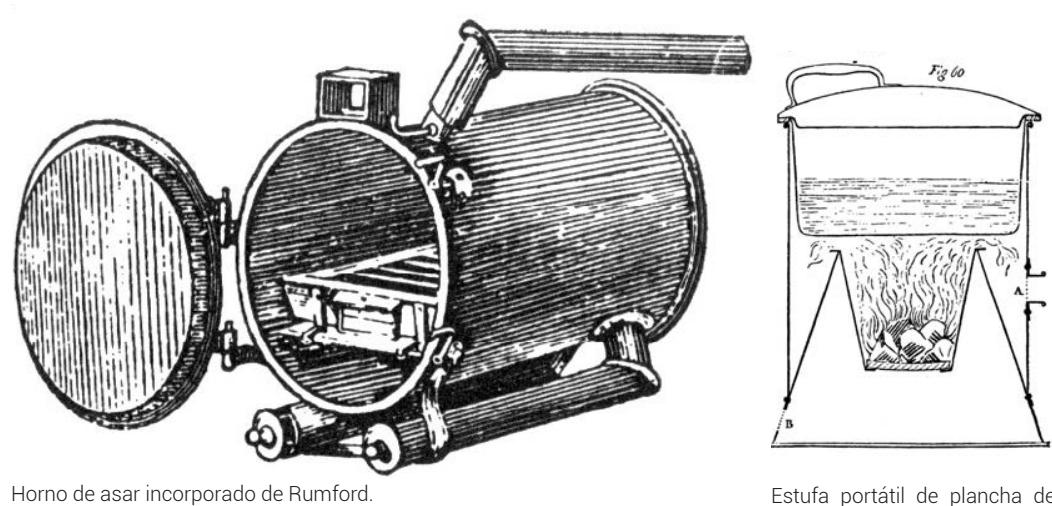

Estufa portátil de plancha de hierro con fogon phusado de hierro con fogón
Rumford, 1800 .
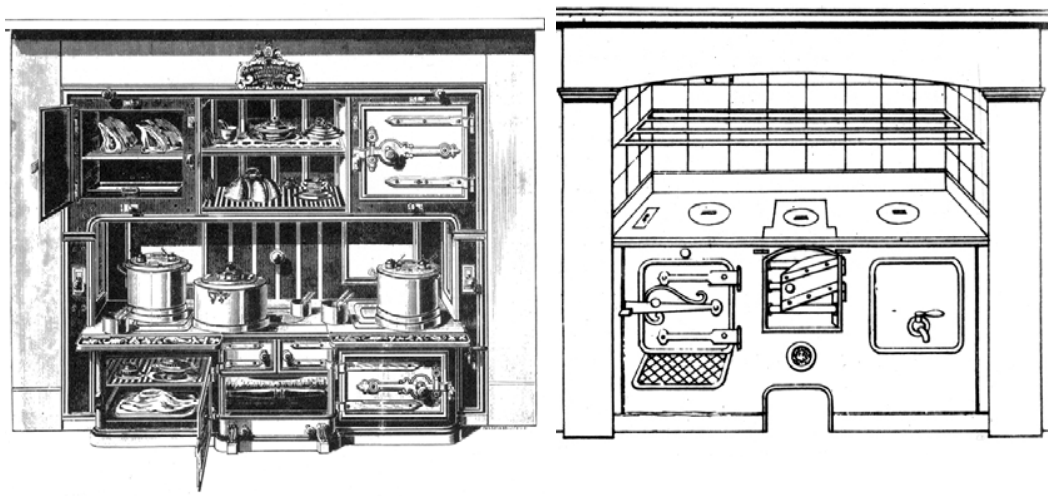

Cocina dentro de una chimena. Aunque el equipamiento de Cocina con depósito lateral, grifo para sacar agua la cocina se moderniza, el conservadurismo en el diseño la placa caliente, compartimento de platos y nichos emsigue insertando dentro de una chimenea. baldosados, hacia 1850

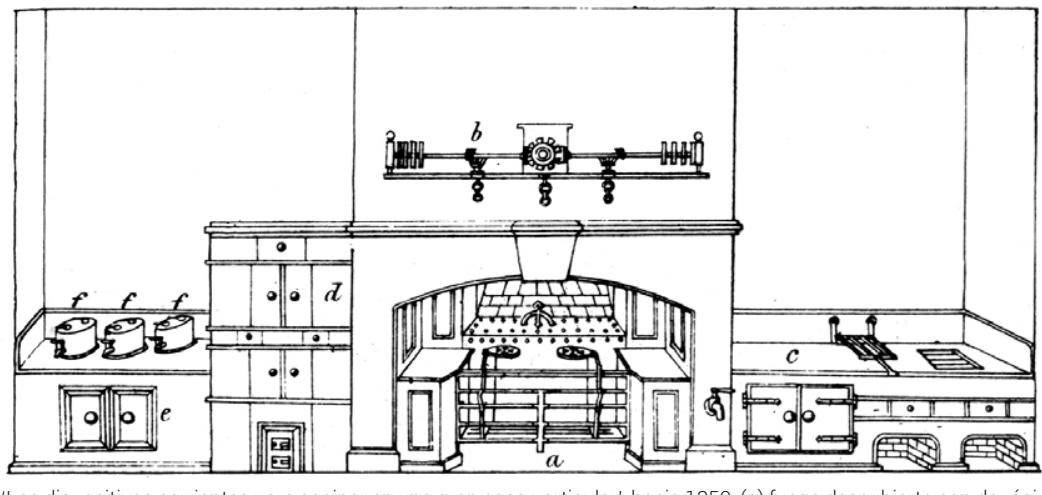

Los dispositivos corrientes para cocinar en una gran casa particular', hacia 1850: (a) fuego descubierto con depóscaliente para calentar platos (d) horno para amasar calentado por fuego separado. (e) armario calentado por vapor del depósito, (fff) ollas de vapor calentadas por el mismo procedimiento.
Con el tiempo, aparecen artefactos específicos donde el fuego queda confinado, de modo que se aproveche mejor todo su poder para cocinar. En castellano, y en otros idiomas, se adopta para estos ingenios el nombre de fogón.

La implantación de la forma y el uso de la chimenea, entendida como hogar, está tan arraigada en la sociedad que durante los primeros años del siglo XIX es frecuente que la cocina, ahora de hierro, se enmarque dentro de ese espacio. Es una cocina cerrada con forma de estufa ${ }^{112}$ que sustituye a la llama descontrolada del fuego directo por una compleja estructura metálica.

De esta manera, y durante algún tiempo, se suceden una gran cantidad de aparatos que se diferencian del periodo anterior porque el horno y la placa constituyen una unidad, dando un primer paso hacia la cocina moderna. Estas cocinas, primero de hierro fundido y más tarde de hierro forjado, y cuyo principal combustible continúa siendo el carbón, constan de al menos tres compartimentos: chimenea o cámara de combustión, caldera o depósito de agua y horno o caja de calor para asar y cocer los alimentos ${ }^{113}$

La fuegos independientes A medida que avanza la tecnología asociada al tratamiento de este material, fundido, forjado y otras aleaciones, se perfecciona también el diseño de las cocinas, así como las posibilidades de agrega accesorios. Es este aparato el más llamativo y voluminoso de las casas acomodadas, y, en un momento determinado, se convierte en una pieza de mobiliario independiente liberándose de la pesada base de piedra o ladrillo ${ }^{114}$. Sin duda esta pieza es la primera de una serie de innovaciones técnicas que se suceden durante el transcurso de los siglos XIX y XX

La escasez de árboles en el continente Europeo debido a su tala masiva para la obtención de madera115, así como las diversas intoxicaciones que con el carbón se suelen producir en el interior del espacio doméstico, son dos de los motivos que provocan que se comience a buscar un combustible alternativo para poder seguir cocinando los alimentos. 


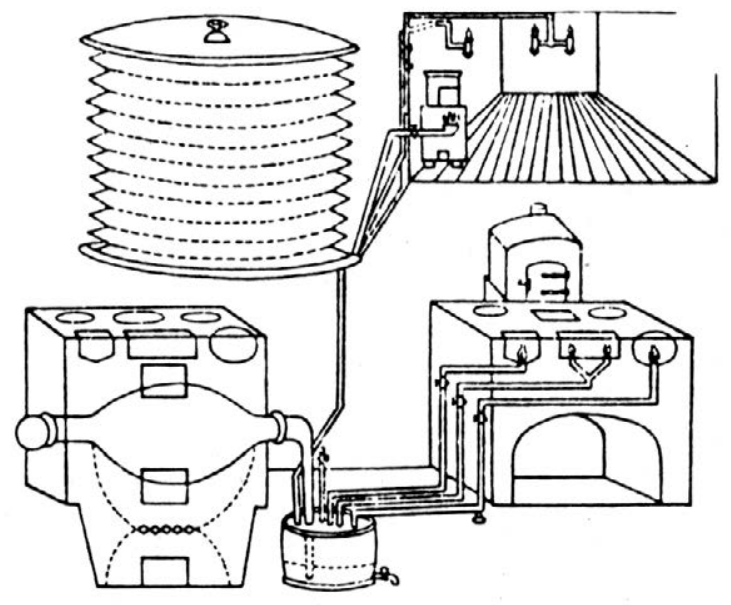

Cocina de gas de Winzler, 1802.

30

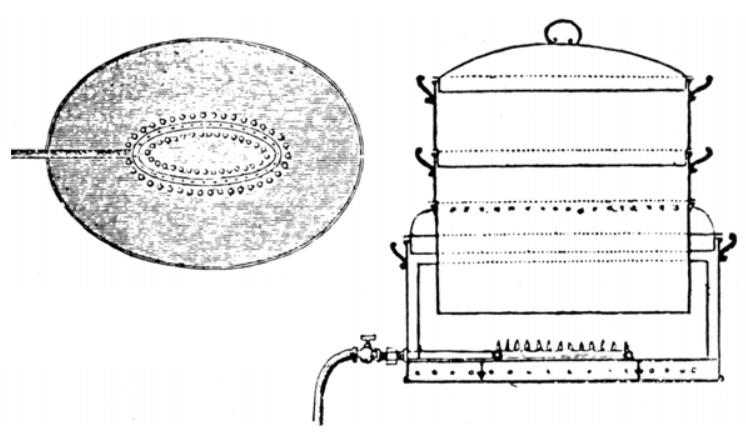

Cocina de gas de Weller, 1839
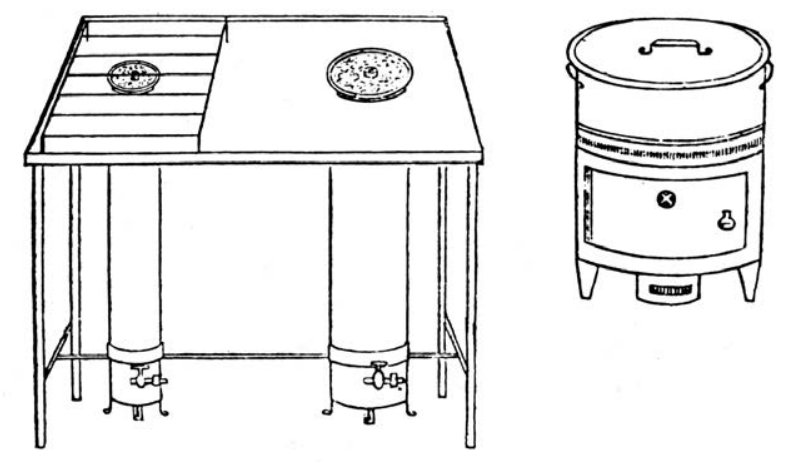

Cocina de gas de Rickett, 1840 .
El gas como nuevo Se desconoce la fecha exacta del descubrimiento del gas ${ }^{116} 117$ aunque combustible lo cierto es que la introducción y difusión de este nuevo combustible, más limpio que la madera o el carbón, se da primero en la ciudad para el alumbrado público ${ }^{118}$ a principios del siglo XIX.

No es hasta 1820, y tras cierta resistencia debido, entre otros motivos, a su precio, dificultad de instalación, falta de seguridad -peligros de explosión e intoxicación- y a cierto romanticismo ${ }^{119}{ }^{120}$, cuando tienen lugar los primeros experimentos realizados con gas en las cocinas de las viviendas ricas. Mientras las casas más pobres siguen cocinando con carbón o leña, las más pudientes cuentan con placas y hornos de gas $^{121}$.

Sin embargo, la nueva tecnología para cocinar no se detiene. Tras las primeras demostraciones públicas realizadas en 1802 por Winzler ${ }^{122}$, la historia apunta a 1832 como el año en el que aparece por primera vez una cocina segura de gas en el espacio doméstico. Sucede cuando James Sharp inventa y ensaya en su casa de Northampton este prototipo ${ }^{123}$

A este primer invento le suceden diversas patentes, como el 'asador de gas' -horno de gas- de 1931, de Hicks; la patente Weller de 1939, o, un año más tarde, la de Ricketts, que patenta un modelo de cocina consistente en una mesa metálica con patas a la que se le practican dos orificios para la ubicación, en la parte superior, de bombonas de gas $^{124}$. 118) De las velas de cera empleadas desde los fenicios antes del 400 antes de Cristo al queroseno inventado en 1858 por Abraham Gesner, la evolución de la luz artificial encuentra en Baltimore (1816), París (1819) y Berlín (1826) antes que en el espacio doméstico. (RYBCZYNSKI, Witold. 1986. 146). 119 Muchas de las cocinas construidas en hierro fundido entre 1800 y 1870 se enmarcan dentro de la forma de una chimenea con el fin de que el usuario tenga la sensación de que aún posee su entrañable y acogedora chimenea (ESPINET, Miguel. Op.cit.90).

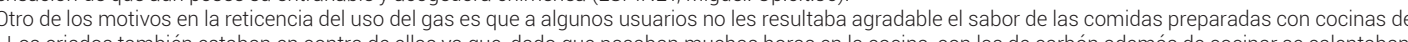
a la cocina con las de carbón además de cocinar se calentaban. mientras que con la de gas en invierno pasaban frío.
121 RYBCZYNSKI Witold 1986.149. 


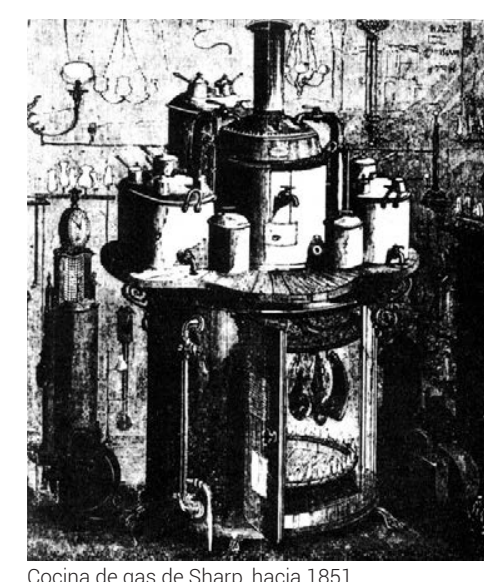

Cocina de gas de Sharp, hacia 1851.

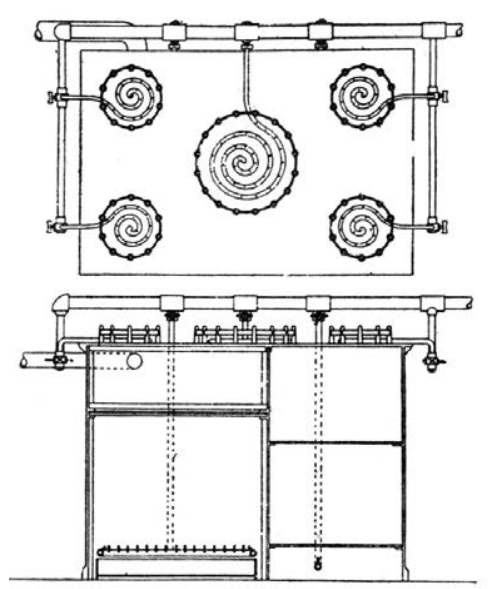

Cocina de gas Graham, 1851

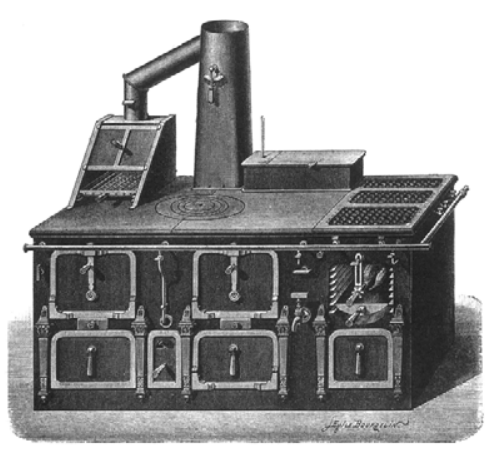

Cocina mixta de gas y coque, 1890 Dispone de varios hornos, grill, hornillos, Baño María y

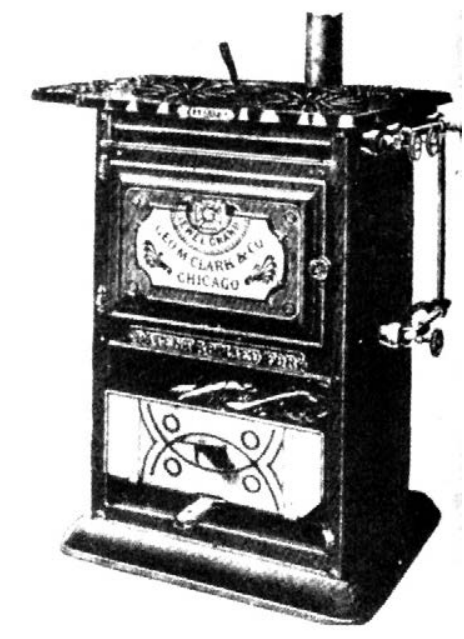

El restaurante urbano De cualquier manera, lo que da el impulso a este nuevo combustible es la figura del restaurante, que se populariza a partir de la Revolución Francesa ${ }^{125}$ en toda Europa, cuando los cocineros son expulsados de palacio y, o bien se quedan en la ciudad, o bien salen del país. Los restaurantes, cuyos primeros establecimientos se ubican en las ciudades que cuentan con fábricas de gas, son los pioneros en adoptar esta nueva tecnología, ya que, frente a la leña o el carbón, resulta más barata.

Es el caso de un restaurante en Glasgow, en 1851, que plantea una cocina metálica, la cocina de Gas de Graham, con cinco quemadores en espiral, uno central de mayor tamaño y los otros cuatro en sus respectivas esquinas, a la que se le incorpora además un horno y un armario caliente ${ }^{126}$

Gracias al impulso de los restaurantes, a partir de 1880 el público comienza a perder su desconfianza con respecto al fogón de gas. Sin embargo, no es hasta 1930, al menos en Europa, coincidiendo con una reducción drástica del servicio doméstico, cuando se perfeccione este sistema y se instala definitivamente en la vivienda.

Con el tiempo, el gas sustituye a la leña y el carbón como fuente de calor en la cocina por su eficiencia, limpieza, potencia, comodidad y control. Además, permite recuperar el tacto de la llama con los utensilios, así como la velocidad de cocción perdida, al introducir un elemento intermedio entre el fuego y las cacerolas.

A pesar de que la introducción del gas supone una mejora tanto en la seguridad como en el confort, muchas de las primeras cocinas de gas emiten una débil llama que apenas calienta ${ }^{127}$. Los primeros modelos, que se diseñan como si fueran cocinas exentas de carbón ${ }^{128}$, recurran a la solución de la cocina mixta para obtener la ventaja de los dos sistemas. Esta situación tiene un importante efecto que retrasa la aparición de la superficie continua de trabajo de la cocina. 


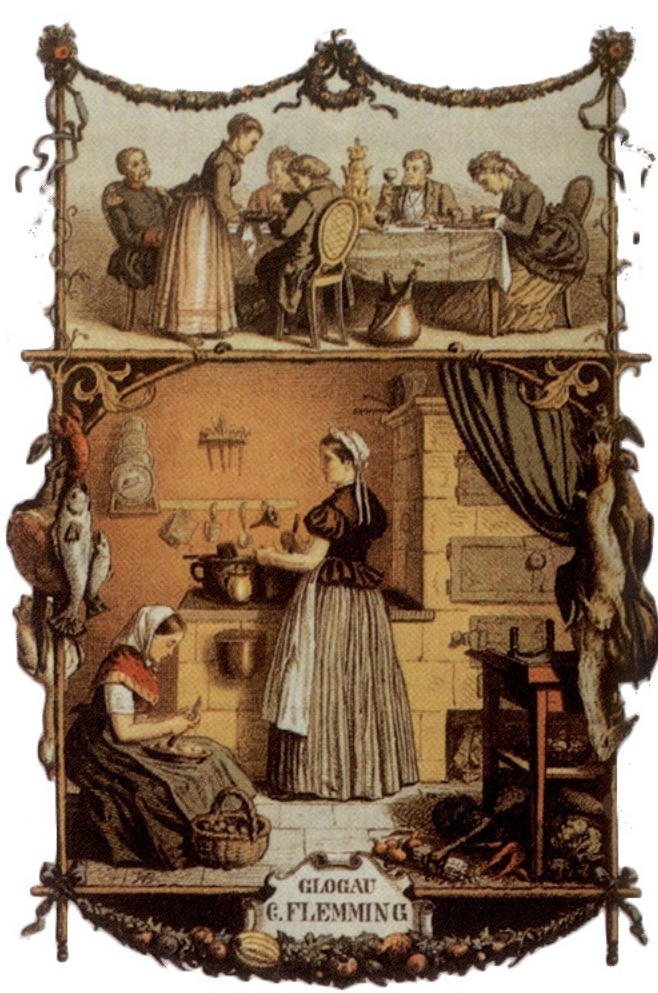

Portada de 'El libro de la cocina práctica' de Auguste Weiss y Ernst Marticke, 1875

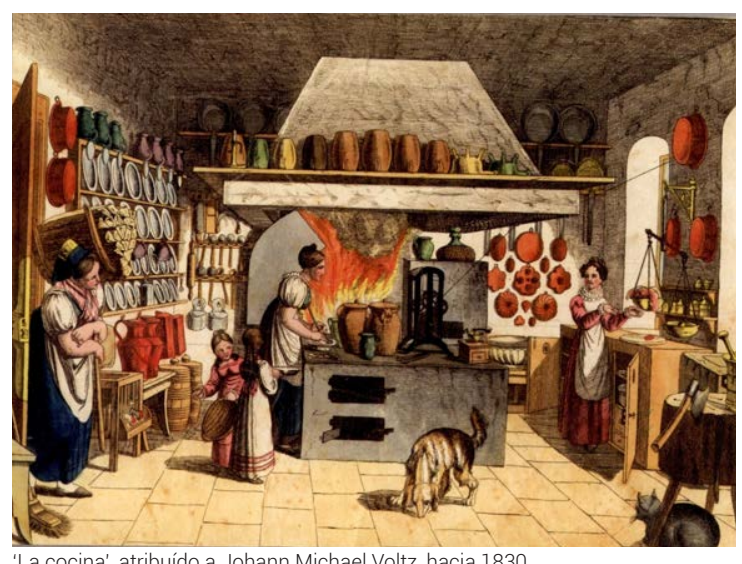

Hasta mediados del siglo XIX la cocina es una habitación oculta, relegada al final del pasillo, destinada al servicio doméstico y que despide malos olores. A partir de entonces, con la transformación de nuevas fuentes de calor, este lugar de elaboración y trabajo de los alimentos muta para hacerse más visible dentro de la vivienda.

La reorganización de la Si Rumford es el artífice de la cocina moderna a finales del siglo XIX cocina a partir de la implantación de una nueva tecnología en dicho espacio la mujer americana es la encargada de su reorganización. Después de muchos años en los que el espacio doméstico apenas varía desde el punto de vista espacial, el período entre 1870 y 1880 en Estados Unidos anticipa lo que es la planificación del hogar a partir del siglo $X X$

Por un lado, la creciente mecanización del siglo XIX y su repercusión en el hogar; y por otro lado, los cambios sociales que se avecinan en relación al status de la mujer dentro de la sociedad y el estatus de servicio doméstico ${ }^{129}$, colaboran a los cambios en la cocina.

En un país con principios democráticos de iqualdad tan poderosos como Estados Unidos resulta inadmisible que exista una clase no liberada tanto como un sexo privilegiado; además, se considera que el servicio doméstico es un convencionalismo social caro e innecesario ${ }^{130}{ }^{131}$. Oponiéndose al empleo de sirvientes, la mujer estadounidense hace ella misma todas sus tareas domésticas, o al menos buena parte de ellas.

A finales del siglo XVIII Thomas Jefferson, teórico político americano, intenta hacer una representación espacial esquemática de un ideal de democracia, favoreciendo la granja familiar frente al modelo de construcción de ciudades de Nueva Inglaterra: son los colectivos puritanos de 'las ciudades del amor fraternal'.

A lo largo del siglo XIX y principios del XX, aunque se sigue discutiendo sobre el modelo de ciudad, los asentamientos espaciales y sociales de los primeros colonos dan paso al distanciamiento entre la ciudad y el campo, el capital y el trabajo. Los hombres de negocios abandonan con sus familias el centro de la ciudad, con sus peligros e incomodidades, y se instalan en viviendas suburbanas que recuerdan los valores de las comunidades puritanas. 


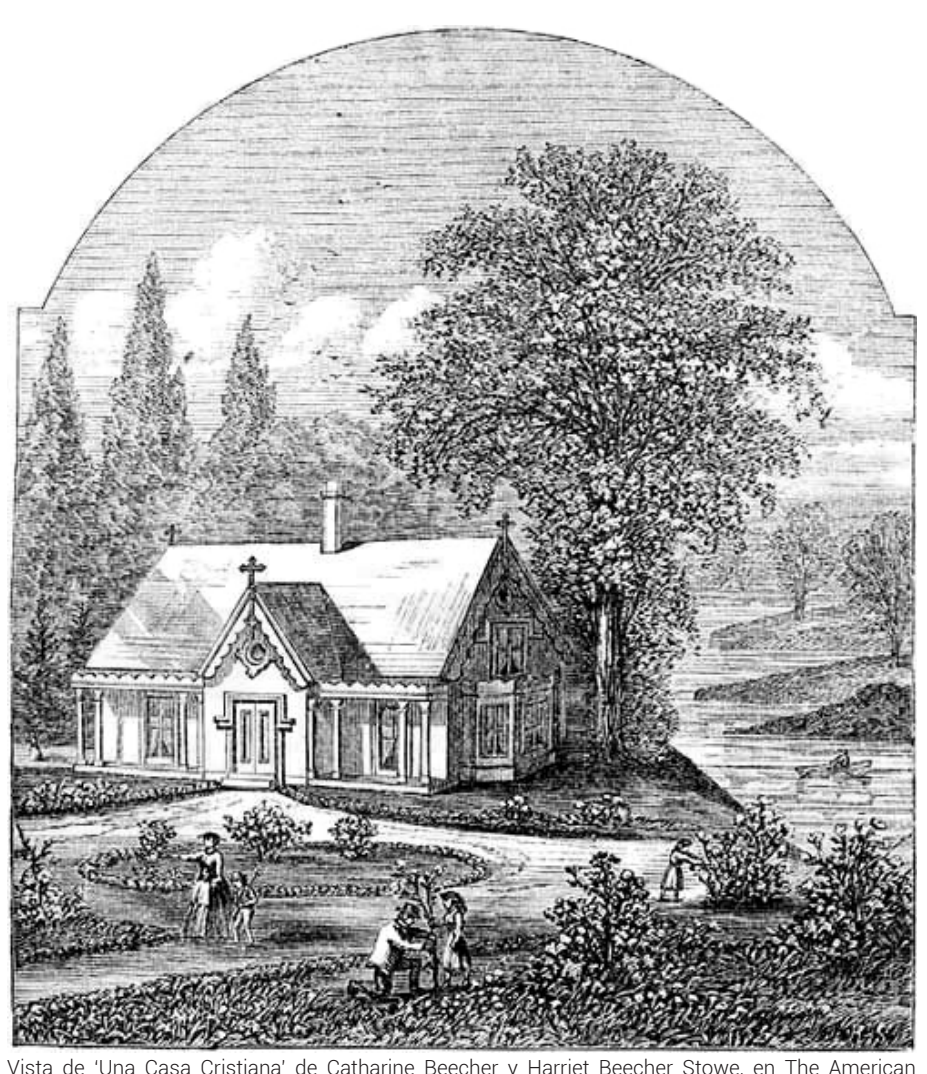

Woman's Home, Nueva York, Estados Unidos, 1869
El desarrollo de estas ideas coincide con la finalización del ferrocarril intercontinental en 1869, que conecta las dos costas -la Atlántica con la Pacífica- del vasto continente americano. De este a oeste, el nuevo medio de transporte construye la nueva unidad geográfica americana. Es un dato fundamental que permite entender no solo la dimensión tecnológica del país, sino que también marca el desarrollo de las viviendas. En este contexto, la casa suburbana para la familia americana cristiana nace como un elemento aislado inserto en el territorio americano conquistado por el ferrocarril para habitarlo ${ }^{132}$.

Los primeros prototipos de la periferia, diseñados por Catharine Beecher, un ama de casa estadounidenses, son concebidos como espacios para el trabajo doméstico de las mujeres al servicio de los hombres y los niños.

Su objetivo es equiparar la participación del hombre en la producción agrícola o industrial mediante el control del espacio doméstico, intentando mitigar el conflicto de la clase en la diferencia de género al construir una identidad común para todas las mujeres en el trabajo doméstico. Frente a los modelos de espacios domésticos privados determinados por sexo, a la granja familiar idealizada de Jefferson y a la casa suburbana de Beecher, desde 1840 hasta 1870 los movimientos abolicionistas y feministas unieron su esfuerzo y consideraron la ciudad ideal como la expresión espacial de los derechos en cuestiones de política y espacio social.

El ángel del hogar El calor de una idealización de la familia nuclear provoca que el estadounidr spacio doméstico, ahora el sagrado templo del hogar se cargue de valores morales. En él, el lugar de la mujer se idealiza hasta el punto de concebirla como la guardiana de dichos valores, siendo su representación cultural más frecuente la del 'ángel del hogar', figura etérea y abnegada ${ }^{133}$ cuya trayectoria social se circunscribe, forzosamente, a un proyecto de vida donde el eje es la familia' ${ }^{134}$ 


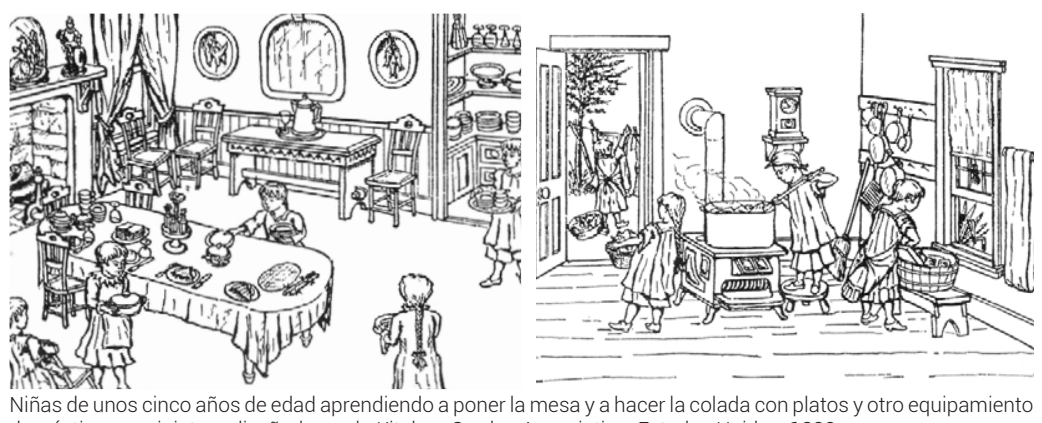

Niñas de unos cinco años de edad aprendiendo a poner la mesa y a hacer la colada con platos yo
doméstico en miniatura diseñado por la Kitchen Garden Association, Estados Unidos, 1883.
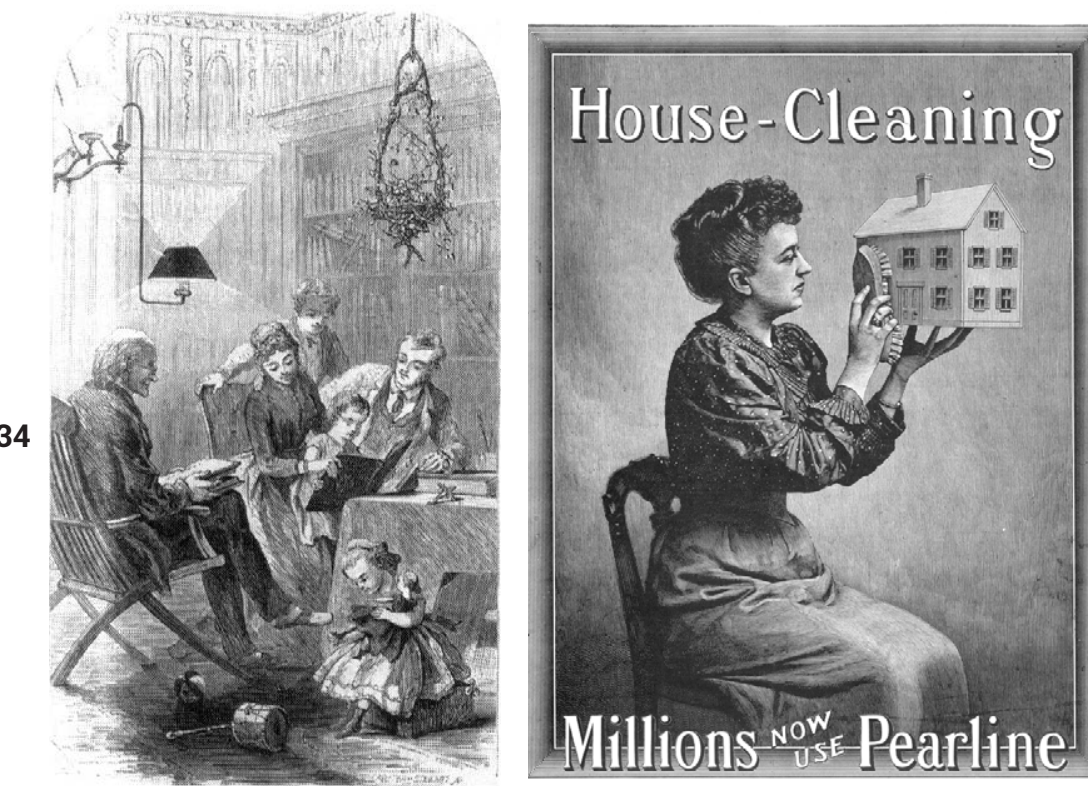

Frontispicio de 'Una Casa Cristiana' de 'The American Woman's Home', Nueva York,

Anuncio de jabón Pearline, Estados Unidos, 1892 a mujer como única responsable de las tareas domésticas
Parece que la mujer posee una sensibilidad especial, una moralidad superior, y una naturaleza sensible que la hace diferente. Existe para la reproducción y el matrimonio, que son los factores que definen el máximo horizonte de su identidad personal y realización vital, sin que exista la posibilidad de crear ningún proyecto social, cultural o labora autónomo como individuo.

Beecher no discute que el sitio de la mujer esté en casa, pero denuncia que la casa no es un lugar bien ideado para quedarse en ella. Expresa un punto de vista que no se había escuchado desde el siglo XVII en los Países Bajos: el del usuario ${ }^{135}$.

La casa sin sirvientes De la misma manera que la mujer holandesa reinventa su papel en la familia del siglo XVII como responsable de una familia más reducida -haciéndose cargo de la educación y el cuidado de todos los miembros y el espacio que compartían-, la familia americana fusiona la felicidad y la eficacia en una forma de proceder que incorpora conocimientos tanto del trabajo industrial como de los proyectos compartidos en las primeras reuniones femeninas. Así logra un hogar que funciona física y afectivamente a la perfección, sin ayuda exterior.

Las tareas domésticas, que tradicionalmente se consideran como un acto de amor de la mujer, son demandadas por Beecher como un oficio remunerado que puede ser enseñado en las escuelas bajo el concepto de economía doméstica. Por supuesto, este tipo de enseñanza va exclusivamente dirigido a las mujeres, ya que solo mujeres debidamente adiestradas podían alcanzar el estatus al que están destinadas ${ }^{136} 137$ 


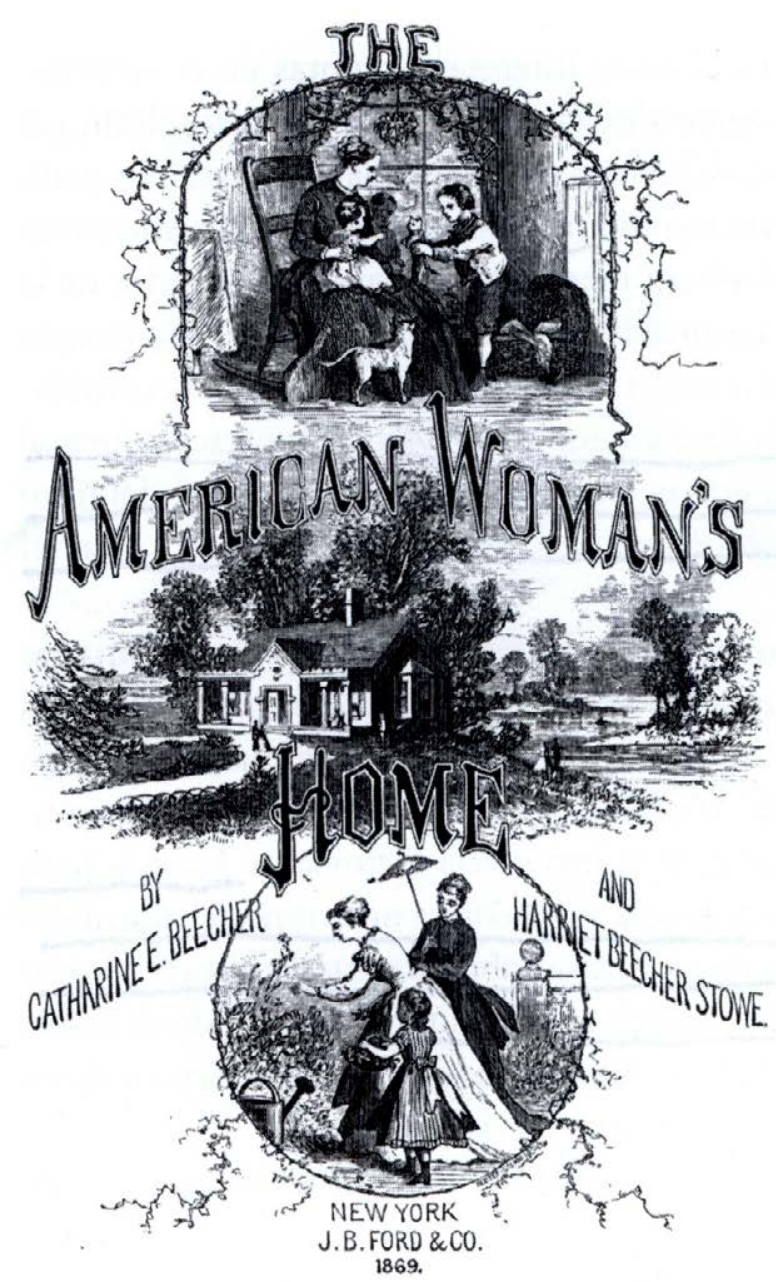

Portada de 'The American Woman's Home' de Catharine Beecher y Harriet Beecher Stowe, Nueva York, Estados
De este modo se establecen las 'Ciencias de la Economía Doméstica' como disciplina académica en la década de 1890. Se forja una 'ciencia' del consumo que enseña a las mujeres a emplear de forma eficaz su tiempo y su dinero, y, en última instancia, a proyectar sus habilidades domésticas hacia la comunidad ${ }^{138}$.

La ingenieras domésticas Consecuentemente, los 'Ángeles del Hogar' pasan a denominarse 'Ingenieras Domésticas'. Son un grupo liberal de amas de casa americanas de clase media que buscan mejorar sus condiciones laborales mediante la redefinición espacial y económica del área de trabajo de sus viviendas. Ángeles, reinas y organizadoras del hogar, las mujeres comienzan a entrar en el debate sobre los usos del espacio doméstico.

Enuncian que solo a través de la aplicación de las metodologías utilizadas en los sistemas de producción de la industria se puede conseguir la simplificación de las tareas domésticas. Su objetivo, básicamente, es la optimización del trabajo doméstico mediante la organización y la reducción de los trabajos innecesarios.

En 1869 Beecher, junto a su hermana Harriet, publican el libro The American Woman's Home (La Casa de la Mujer Americana) ${ }^{139}$. Es uno de los muchos manuales de organización doméstica que aparecen entre los siglos XIX y XX tanto en América como en Europa. Parten del esquema de vivienda aislada de la familia cristiana, planteando una reorganización en planta del proceso de trabajo antes de que la mecanización de los aparatos haga su aparición ${ }^{140}$.

Sin duda uno de los grandes logros de estas ingenieras domésticas es la ampliación del concepto de confort doméstico. Concretamente es en el ámbito de la cocina donde se presta una mayor atención; el ahorro del esfuerzo debe primar sobre cualquier otra consideración, pero además el trabajo también debe realizarse bajo condiciones de confortabilidad.

\section{5}




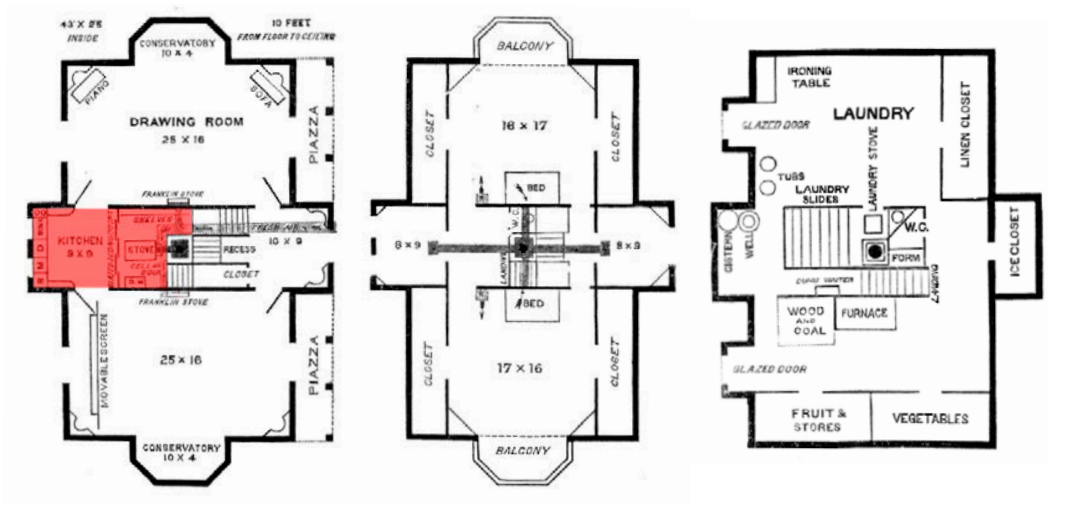
Planta principal, segunda y sótano de la vivienda en 'The American Woman's Home' de Catharine Beecher y Harriet
Beecher Stowe, Nueva York, Estados Unidos, 1869.
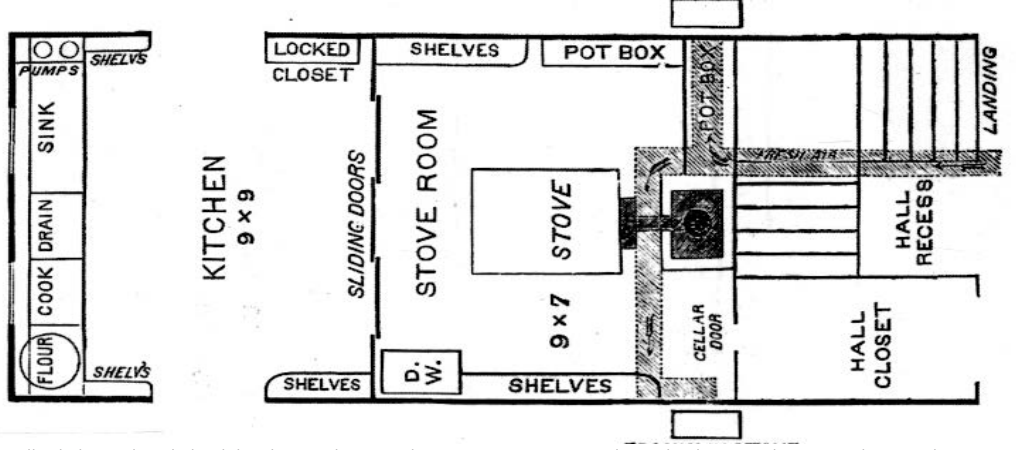

Detalle de la cocina de la vivienda en 'The American Woman's Home' de Catharine Beecher y Harriet Beecher Stowe, Nueva York, Estados Unidos, 1869.

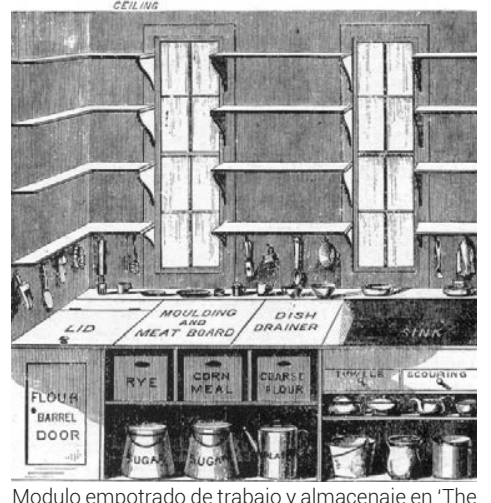

American Woman's Home' de Catharine Beecher $y$ Harriet Beecher Stowe, Nueva York, Estados Unidos, 1869
La cocina eficiente La primeras cocinas organizadas bajo estos criterios se realizan estadounidense en las construcciones navales del siglo XIX. Los barcos de vapor disponen de cocinas muy bien organizadas en las que los cocineros tienen a mano todo lo necesario. De esta manera, y basándose en la cocina de los barcos Mississippi -Mississippi streamboats- ${ }^{141}$ Beecher incorpora los planteamientos de dichas soluciones y los desarrolla, en 1869, en su libro: una 'cocina ideal' eficiente para la casa suburbana americana ${ }^{142}$

Se trata de un espacio que ocupa una posición central en la vivienda que se divide en dos zonas: la de almacenaje y la de cocinado. Con una superficie de nueve metros cuadrados, se destina a la preparación de los alimentos, el almacenamiento y la planificación, ya que la verdadera ama de casa hace de su pan el soberano de su cocina ${ }^{143}$.

Para evitar olores, humos y un exceso de temperatura ambiental en el resto de la vivienda; Beecher independiza los fogones de gas, que, conectados a la chimenea, sitúa en una habitación independiente de siete metros cuadrados separada por puertas correderas.

Precursora de la cocina moderna, lo novedoso de este modelo es que por primera vez la cocina se organiza en función de superficies de trabajo continuas apoyadas en la pared y bien iluminadas por ventanas. La gran mesa desaparece y el aparador aislado es sustituido por estantes, cajones y receptáculos bajo las superficies ${ }^{144}$ concentrando las funciones de trabajo y almacenaje en un solo mueble especializado. La cocina dispersa se vuelve compacta.

A pesar de esta nueva y revolucionaria forma de organizar la cocina, no es hasta los primeros años del siglo XX cuando esta pieza comienza sistematizarse gracias a la secuencia racional del proceso de trabajo. Hasta entonces los distintos componentes de las cocinas son dispares y sin compatibilidad, por lo que no se pueden reunir bajo una misma superficie de trabajo. 
Los primeros pasos hacia esta concepción unitaria y estandarizada de la cocina se dan inicialmente en la industria hotelera, los principales interesados en adquirir los elementos compatibles de manera conjunta.

La eficiencia en las tareas En el contexto de la mecanización de principios de siglo XX la ausencia de sirvientes en la casa americana se complementa con los nuevos aparatos eléctricos, que no solo ahorran tiempo, sino también esfuerzo, permitiendo que las tareas de la casa se realicen con más comodidad. La obsesión por reducir el tamaño de la casa por parte de las amas de casa no es solo económica, sino que lleva una ideología implícita vinculada al confort. Al ser más fácil de cuidar y utilizar una casa pequeña, esta puede ser más confortable que una mayor ${ }^{145}$

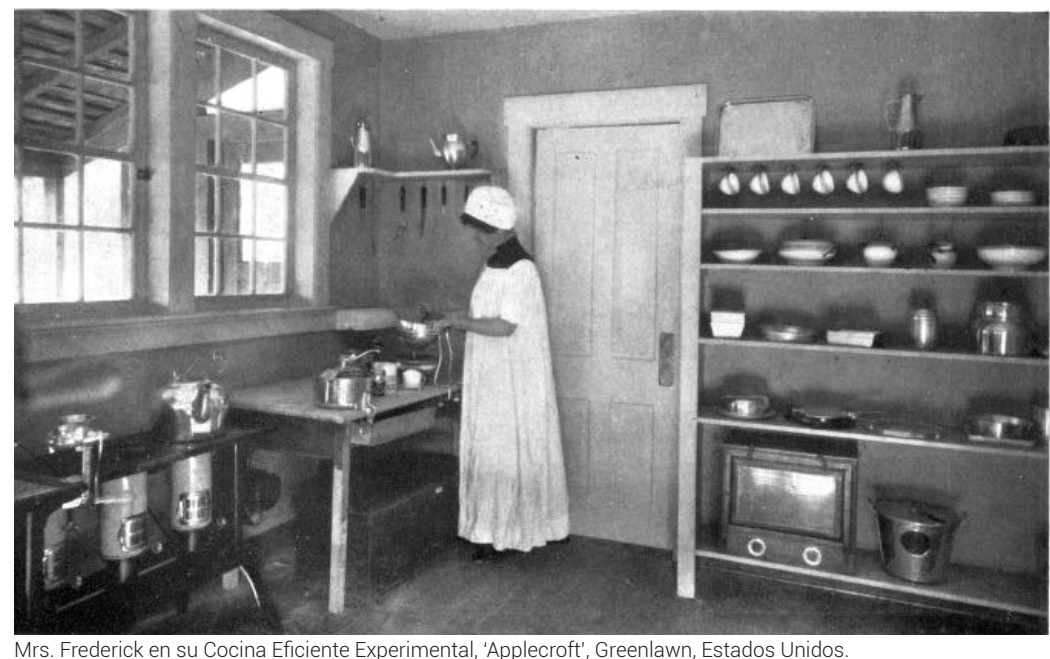

La reorganización del trabajo doméstico en Estados Unidos comienza a finales del siglo XIX con el movimiento de 'liberación' de la mujer, aunque no es hasta los principios del siglo XX cuando la organización científica de trabajo le da el impulso definitivo ${ }^{146}$.

Durante los primeros años del siglo XX es frecuente el empleo de metáforas entre la industria y la cocina privada. Probablemente la más lograda se encuentra en el Taylorismo, una técnica de gestión que divide el proceso productivo en una serie de tareas más pequeñas, reduciendo a los trabajadores a 'máquinas' de una línea de montaje que repiten una misma tarea una y otra vez ${ }^{147} 148$

En este marco, Dolores Hayden subraya la influencia que tienen en la reforma del entorno doméstico -a partir principios del siglo XXfiguras como Christine Frederick, Mary Pattison y Lilian Gilbreth ${ }^{149}$. 
The New Housekeeping Efficiency Studies in Home
Management

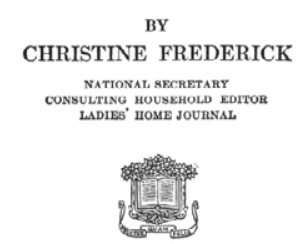

ILLUSTRATED

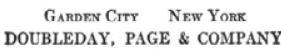

1914
STANDARDIZING CONDITIONS only stops to think. Let me state it in this

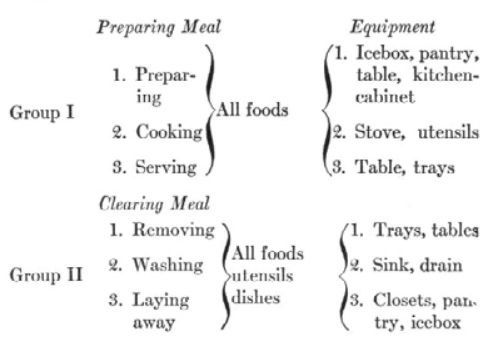

Suppose, for instance, we wish to make an omelet. We take eggs and milk from the icebox or pantry (follow diagram), beat it at a table, cook on stove, serve on platter, and take to dining-room. This is the preparing process of this dish, and is the simplest method we can follow. On the return trip, or the processes of clearing away, I take the empty platter from the dining-room to the kitchen sink, wash it, and lay it away.

\section{[49]}

División del trabajo en el libro 'The New Housekeeping' de Christine Frederick, Nueva York, Estados Unidos, 1914.
Las ciencias económicas Aprovechando el interés por las 'ciencias económicas domésticas' domésticas de final del siglo XIX, Frederick intenta racionalizar los distintos equipos de cocina existentes - fuegos/horno, fregadero, refrigerador almacenaje y mesa- a través de unos experimentos patrocinados por la revista femenina Ladies' Home Journal. La aplicación de los principios de eficacia y gestión científica del Taylorismo no solo revelan la ineficacia de las costumbres domésticas de la mayor parte de las viviendas ${ }^{150}$, sino que, al contrario que las propuestas de Beecher, determinan el desarrollo de la cocina moderna tanto en América como en Europa ${ }^{151}$.

Frederick busca aplicar los métodos del sector industrial a las tareas domésticas para aumentar la eficacia y el rendimiento en términos de tiempo, energía, espacio y dinero. Para ello visita fábricas y oficinas donde se aplican estos principios, y, con ayuda de diagramas y fotografías, expone cómo se pueden hacer tareas como cocinar lavar, limpiar o recoger de una manera más eficiente.

Hábilmente clasifica las heterogéneas actividades que tienen lugar en la cocina vinculándolas a un determinado mobiliario y a unos aparatos específicos, estableciendo lo que probablemente sea la mayor aportación a la cocina: la separación radical entre dos actividades básicas: la preparación de los alimentos -cocinar- y el lavado de la vajilla después de las comidas -recoger-152. 


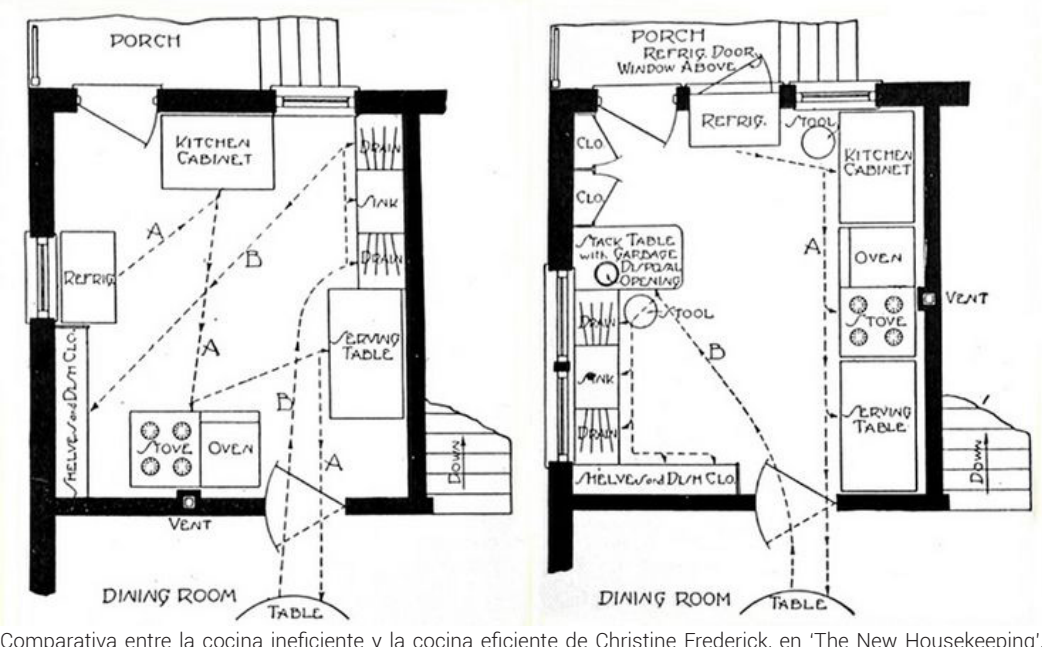

Comparativa entre la cocina ineficien
Nueva York, Estados Unidos, 1914.

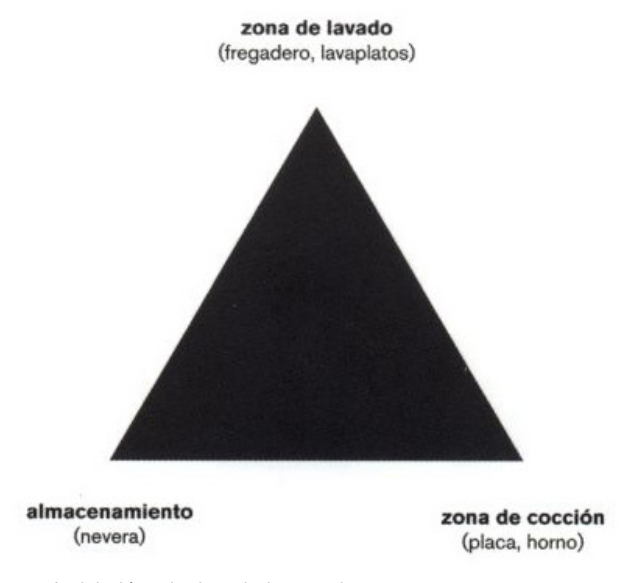

Frederick continúa con las investigaciones de Beecher al proponer una cocina con superficies de trabajo continuas, en un espacio de unos once metros cuadrados (3.05 x 3.65 metros_10 x10 pies). El factor clave del diseño está en reunir las tareas y el equipo de cocina fomentando una 'cadena de pasos'. Frederick identifica seis fases: preparar, cocinar, servir, retirar, lavar, colocar. Cada fase requiere de sus propias herramientas y estas deben estar a la altura y posición correcta para la usuaria.

La cocina evicaz vs La cocina ineficaz frente a la cocina eficaz, de Frederick, es el la cocina ineficaz resultado de estos estudios, que, en forma de diagramas, presenta en su libro de 1912 The New Housekeeping: Efficiency Studies in Home Management ${ }^{153}$. Traducido al alemán en 1921 por Irene Witte, ejerce gran influencia para los arquitectos europeos y para el desarrollo en general de la cocina ${ }^{154}$

Dicha publicación se basa en la búsqueda de la eficacia: a menor número de pasos, menor cantidad de utensilios. Los estudios de Frederick desembocan en la teoría del triángulo de trabajo, que organiza la sucesión de movimientos en la cocina, que en la actualidad siguen vigentes para su configuración.

Teoría del triángulo de trabajo actual. 


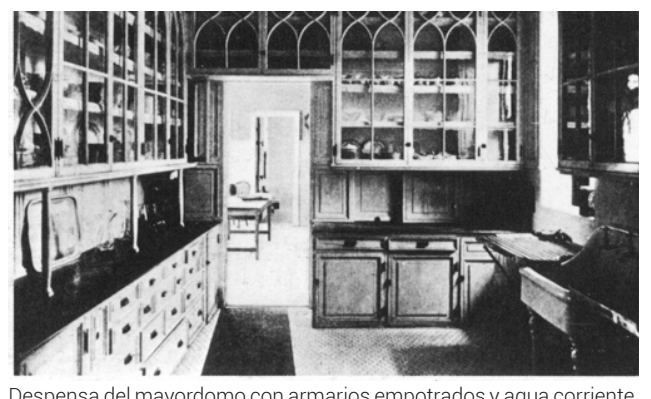

Despensac.

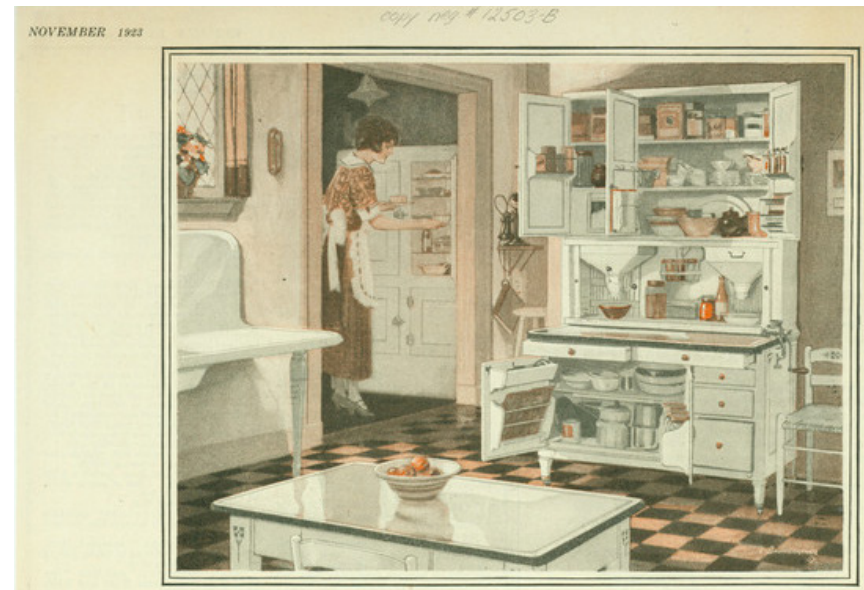

The room where you spend the most working hours make it inviting and attractive as well as convenient

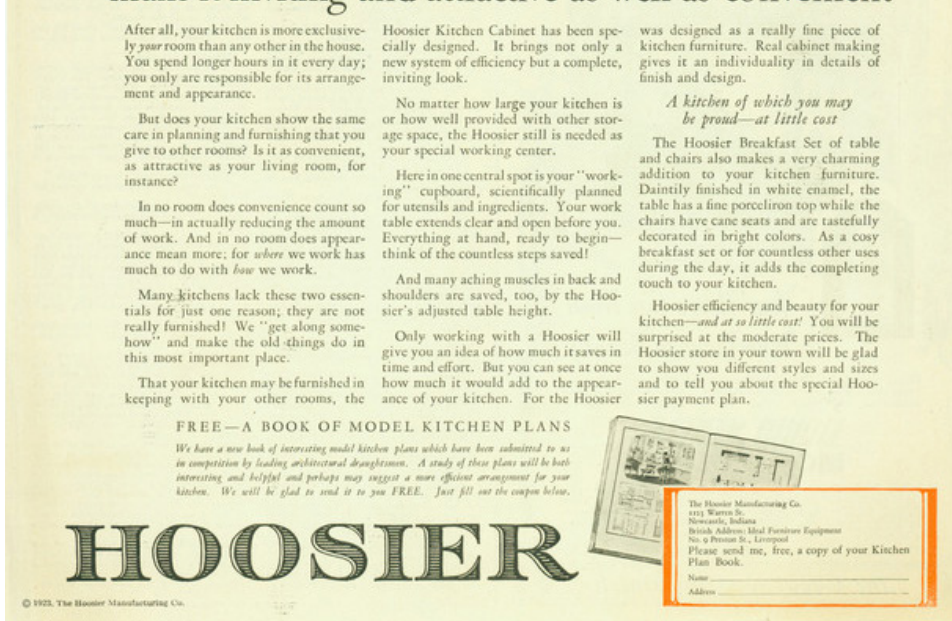

Anuncio del aparador de la marca Hoosier, Estados Unidos, 1923.
Las nuevas formas de Los grandes cambios que operan en el sector alimentario y en consumo las nuevas formas de consumo a principios del siglo XX como consecuencia de la producción industrial provocan transformaciones en la cocina. Frente a la compra a granel, que requiere de un gran almacenaje, se cambia a una compra diaria o 'comercialización frecuente', como dice Frederick ${ }^{155}$. Consecuentemente, las superficies de la cocina se reducen: la antigua despensa ${ }^{156}$ se sustituye por armarios y aparadores situados en la misma cocina.

Sin duda la consecución de la cocina continua no se debe tanto la tecnología como a la reorganización del mobiliario de almacenaje y preparación de los alimentos ${ }^{157}$. En este sentido, la evolución del aparador, presente tanto en los planos de Beecher (1869) como de Frederich (1912) y Gilbreth (1930), es un elemento clave.

La reaparición del aparador Frente al almacenamiento que muestra todos los enseres de la cocina en la cocina en estanterías alineadas a lo largo de las paredes y a la vista de todo el mundo para facilitar su accesibilidad, el aparador de cocina, heredero del aparador de la casa holandesa del siglo XVII, surge como un mueble donde se protegen del polvo, la humedad y las moscas todos los objetos del espacio dedicado a la preparación de alimentos.

Mientras que los armarios murales son propios de las casas burguesas $^{158}$, el aparador, popular desde 1890 hasta la década de los treinta ${ }^{159}$, resulta una alternativa barata fabricada en serie.

Dividido en dos cuerpos, un armario inferior y grande y una pieza superior superpuesta con puertas de cristal, el aparador es un elemento del mobiliario doméstico que consta de un módulo vertical que combina el almacenaje -tanto de alimentos como de utensilios ${ }^{160}$ con una superficie de trabajo continua. En algunos casos un mostrador corredero sirve para ampliar más la superficie de trabajo proporcionando espacio para sentarse.
155 Gracias a la revolución industrial y a la producción en serie se alteran los modos de consumo. El cambio más significativo es el abandono de la compra a
granel, en grandes cantidades, en favor de una compra más frecuente y de productos envasados (BLASCO ESQUIVIAS, Beatriz, 2006. Vol. 2. 124). granel, en grandes cantidades, en favor de una compra más frecuente y de productos envasados (BLASCO ESQUVIVAS, Beatriz, 2006. Vol. 2. 124). entre la cocina y el comedor para almacenar la vajilla y servir las comidas - despensa del mayordomo- (LUPTON, Ellen y MILLER, Abbott. Op.cit. 44). 157 LUPTON, Ellen y MILLER, Abbott. Op.cit. 43

158 Estos armarios se limitan a las casas de los que se pueden permitir realizar una carpintería a medida.
159 LUPTON Ellen $y$ MILLER, Abbott Op cit 47

160 Entre los utensilios encontramos tarros, ollas y sartenes, así como la vajilla y otros accesorios pequeños. 

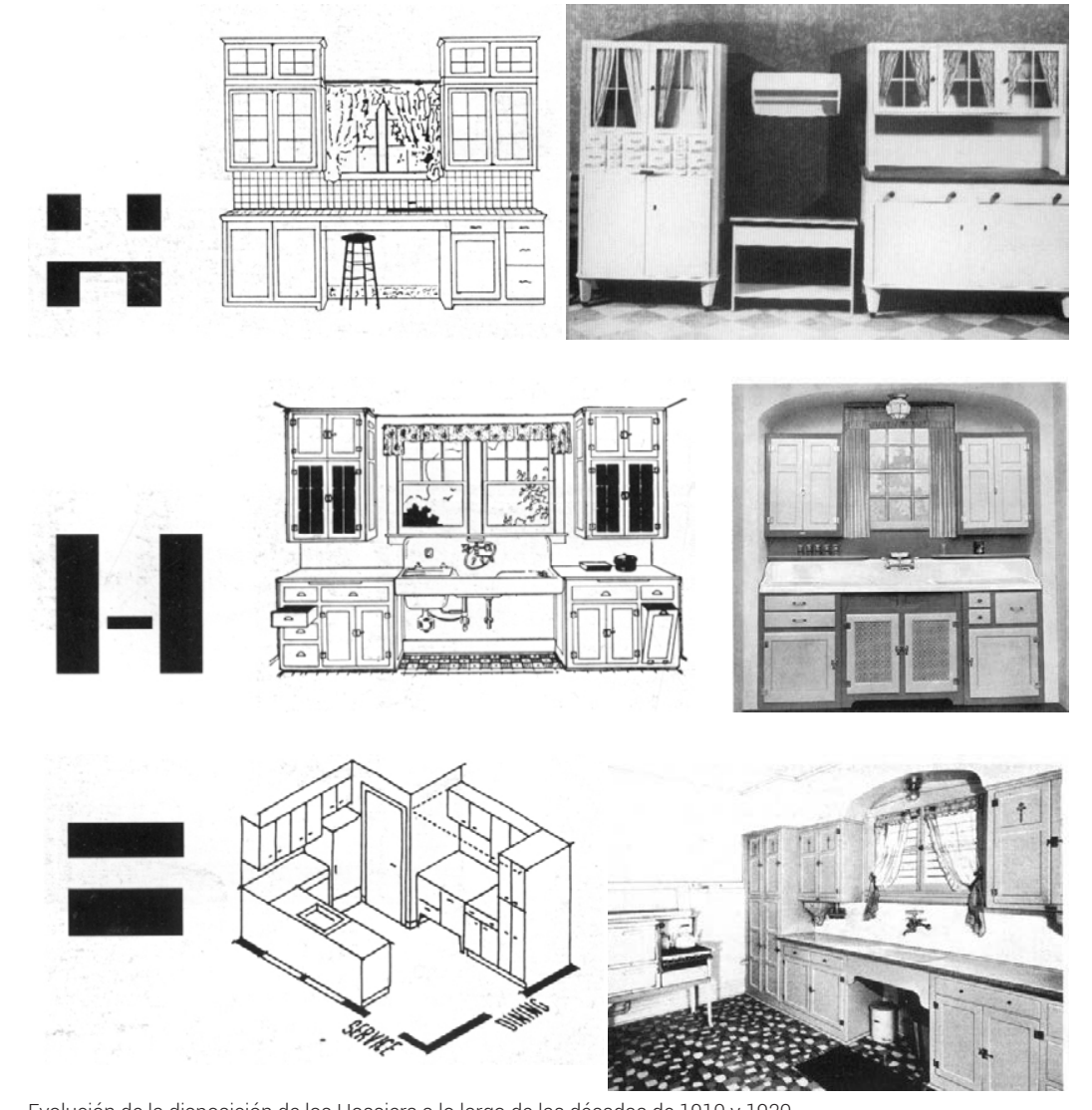

Evolución de la disposición de los Hossiers a lo largo de las décadas de 1910 y 1920.
El aparador Hoosier La Hoosier Manufacturing Company de Indiana es el fabricante más famoso de aparadores de cocina, siendo el Hoosier el nombre genérico que estos armarios altos reciben en Estados Unidos ${ }^{161}$. El Hoosier aglutina muchos de los principios de las teorías contemporáneas sobre la economía doméstica, al concentrar las funciones de preparación y almacenaje en un solo módulo ${ }^{162}$.

Progresivamente, la configuración de este elemento se complejiza, ampliándose por los laterales con dos armarios verticales más estrechos. Estos sistemas murales modulares, individuales o combinados, se consideran muebles independientes, y aunque son una respuesta eficaz a las teorías domésticas de la época, no logran convertirse en norma establecida.

El camino hacia la integración y estandarización de los muebles y electrodomésticos se produce a través de la sink combination: el frigorífico, el horno, el calentador y los armarios se integran debajo de una encimera y un fregadero, generalmente hecho de acero inoxidable.

En las décadas de 1910 y 1920 es cada vez más frecuente situar la pila debajo de una ventana y colocar a cada lado un armario alto o bien Hossiers independientes o módulos empotrados en la parte superior.

Otra variación sobre este diseño consiste en un mostrador y una pila unificados formando un puente entre los dos armarios bajos. Sin duda esta configuración horizontal abre el camino al entendimiento de la cocina en dos niveles distintos. Los armarios de la base, al fin liberados de los armarios murales, recorren libremente el perímetro de la cocina dando lugar, a partir de los años treinta, a la fabricación de los armarios de cocina como sistemas modulares y combinables. 

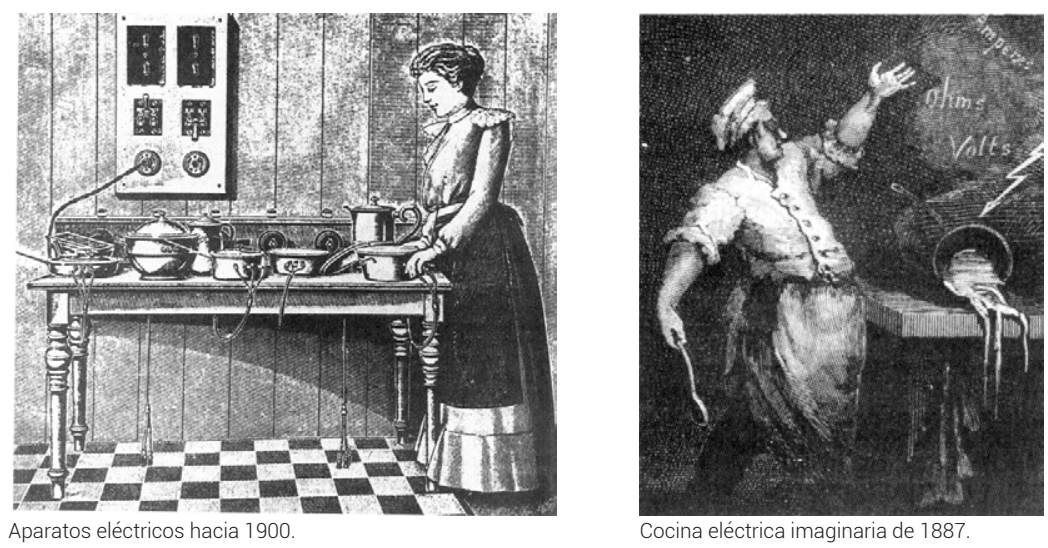

42

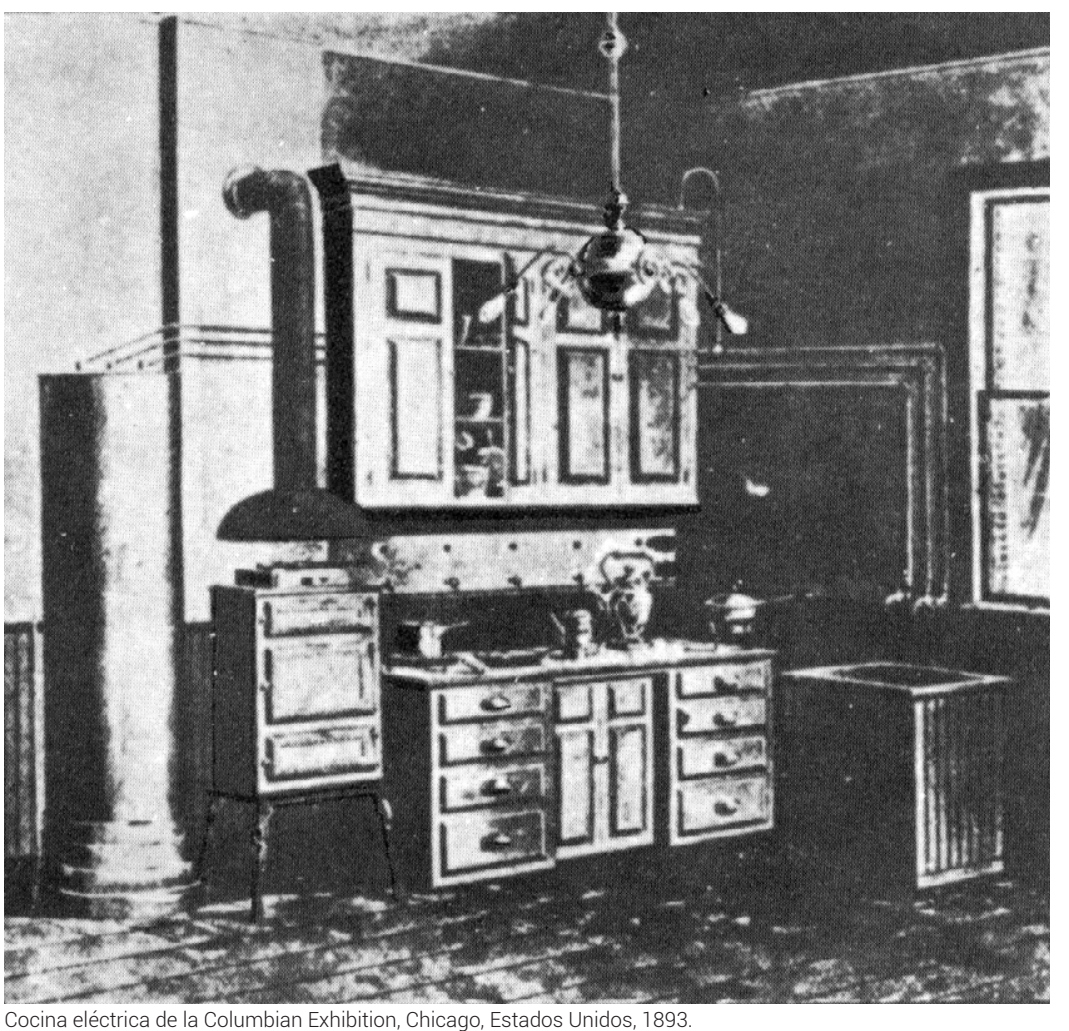

El trabajo de la mujer, como responsable del cuidado de la casa -ya sea como señora, criada o las dos cosas a la vez-, es la principal fuerza motriz de toda la diversidad de aparatos domésticos manuales del siglo XIX, desde las máquinas de coser a las batidoras de huevos, pasando por el lavaplatos, las lavadoras e incluso la aspiradora.

La electricidad y los En este sentido el descubrimiento de la electricidad a finales del siglo electrodomésticos XIX es determinante para la 'liberación física' de las mujeres en la realización de las tareas domésticas. Mientras que los primeros usos de la electricidad se emplean en el alumbrado de las ciudades -que hacia 1900 ya es algo asumido en la vida urbana-, su introducción en el espacio doméstico se realiza poco a poco y a través del pequeño electrodoméstico: la máquina de coser Singer y el ventilador Tesla eléctrico en 1889, la aspiradora en 1901, la lavadora eléctrica Thor en 1909, las neveras en 1917, y el lavaplatos Walker en 1918.

De esta manera, simultáneamente a la generalización del uso del gas y electricidad en el ámbito doméstico, aparece en el primer tercio del siglo XX un nuevo tipo de máquina que contribuye al desarrollo eficiente de los procesos de trabajo, realizados tradicionalmente a mano: los electrodomésticos ${ }^{163}$.

Respecto a la cocina, la capacidad para aportar un calor directo se advierte rápidamente ya en la década de 1880, no sin ciertas connotaciones hacia la brujería ${ }^{164}$. No es hasta 1891, primero en el Crystal Palace de la Exposición Universal de Londres en 1891 y más tarde en la Exposición Universal de Chicago de 1893, cuando se exhibe una Cocina Eléctrica Modelo con cacerola, calentador del agua, horno y depósito, todos ellos conectados con tomas individuales ${ }^{165}$.

La base sobre la que se funda la cocina eléctrica está ligada al invento de las estufas eléctricas. En 1892, una década después de que Edison diera a conocer la lámpara incandescente, los inventores británicos Crompton y Dowsing patentan la primera estufa eléctrica para uso doméstico. Tras el invento de las estufas eléctricas, que usan la electricidad por efecto Joule para el calentamiento, se aplica la técnica a los fogones mediante resistencias arrolladas helicoidalmente en una base de material cerámico, y, más adelante, mediante resistencias blindadas o embutidas en una placa metálica. 

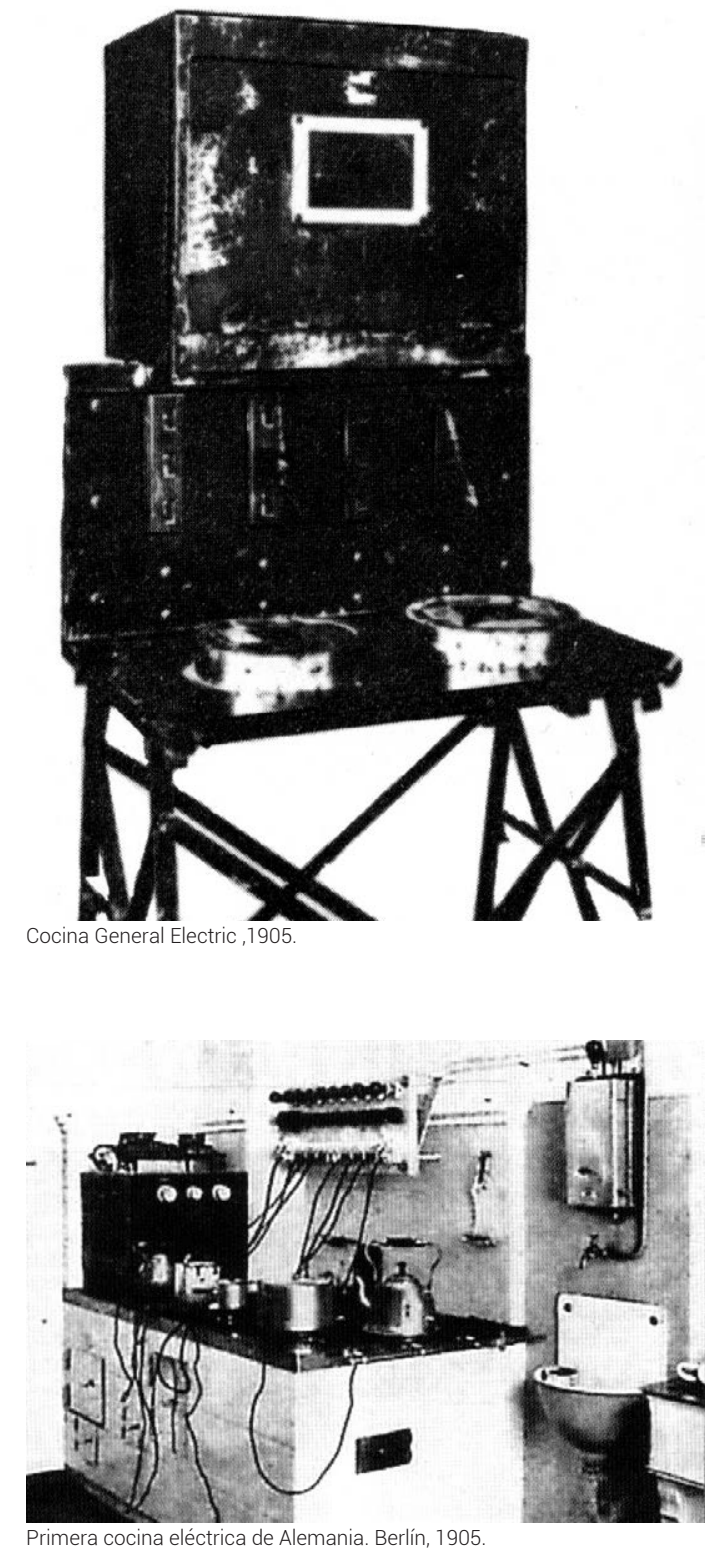

Tiene fuegos, cazuelas y sartenes que se enchufan por separado.
La cocina eléctrica A partir de entonces, los tipos eléctricos que toman como modelo de referencia la cocina de gas -una consola sobre patas, con horno y parrilla sobre superficie de cocción- se suceden, perfeccionándose modelo tras modelo.

Sin embargo, el elevado coste de los aparatos ${ }^{166}$, la precariedad de las redes de distribución eléctrica y la desconfianza que existe hacia el nuevo combustible provocan que no sea hasta 1930 cuando se popularice definitivamente la cocina eléctrica. Un indicio claro de su popularidad es la presencia de estos aparatos en los catálogos de ventas por correo, que, según Giedion, constituye todo un logro de la civilización americana ${ }^{167}$.

La modernización llega a la cocina de la mano de la electricidad. El diseñador Norman Bel Geddes es el primero en proyectar una cocina de nivel único en 1933 para la Standard Gas Equipment Company. Su sistema de paneles modulares marca la base combinatoria del horno y los fogones modernos. Uno de sus mayores logros es la estandarización del material de cocina. El diseño de su cocina modular y aerodinámica Oriole -en 1931- para la Standard Gas Equipment Company tiene un armazón de acero revestido por paneles esmaltados de vidrio blanco

Incluso a finales del siglo XX, a pesar de las cocinas vitrificadas, más fáciles de limpiar y de calor más homogéneo, no se ha roto por completo un cierto rechazo a la utilización de la energía eléctrica en las cocinas, de tal manera que el gas, siempre que esté disponible, sigue siendo la fuente energética más usada para fines culinarios. 


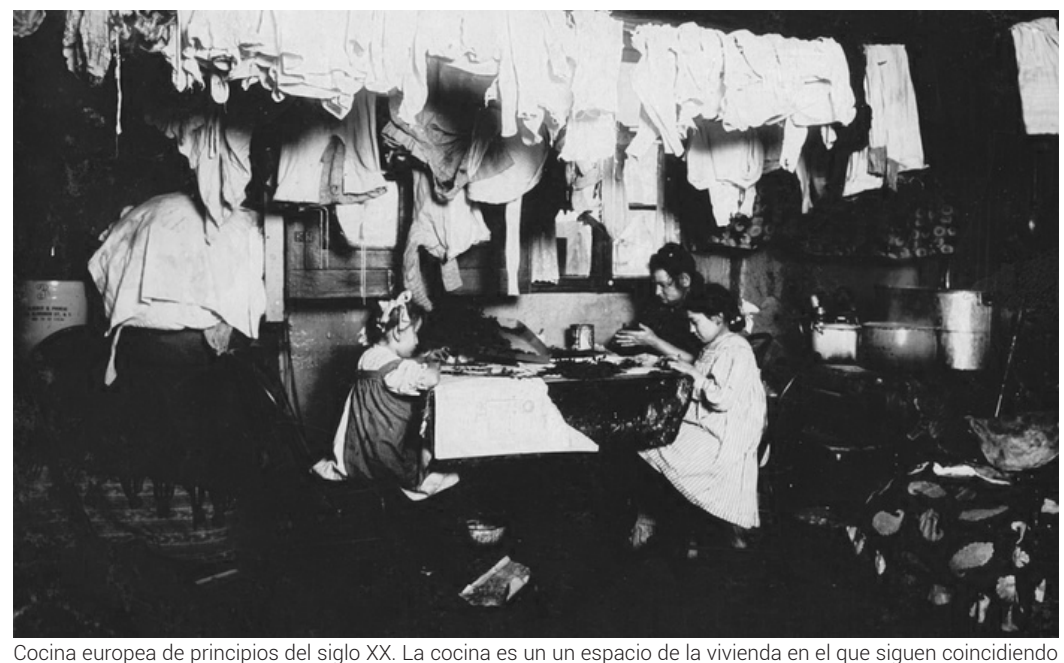

Cocina europea de principios
multitud de usos diferentes.

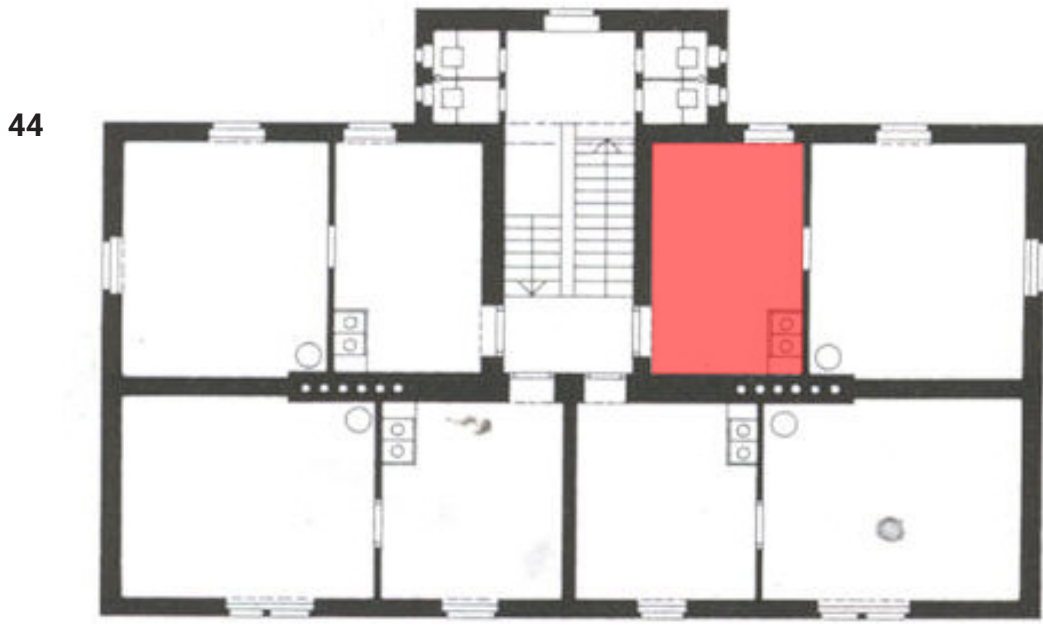

La cocina sigue compartiendo espacio en una gran estancia multifuncional en la vivienda.
En la misma época de finales del XIX, en Europa, con una cultura basada en la tradición y el paternalismo, la situación es muy diferente respecto a Estado Unidos. La lentitud con la que en este continente se desarrolla la industria, y por tanto la gestión científica del trabajo provoca que no sea hasta la década de los veinte cuando comience la organización del hogar.

Al mismo tiempo que la casa en América organiza con más eficiencia el espacio para realizar las tareas domésticas, en Europa, a comienzos del siglo XX, se mantiene el rígido modelo de vivienda burguesa donde todavía la representación y la apariencia son los principales criterios de diseño.

En el continente europeo los tapiceros o decoradores de interiores, desde mediados del siglo XIX y al margen de los arquitectos, toman las riendas de todo lo relacionado con el interior de la casa ${ }^{168}$ 169. Su falta de interés por las nuevas tecnologías y la economía doméstica provocan que el interior doméstico evolucione lentamente retrasándose varias décadas la implantación del modelo americano en la vivienda europea ${ }^{170}$

La cocina insalubre obrera Respecto al resto de las viviendas, la situación es bien distinta. La masiva inmigración de la población del campo a la ciudad como consecuencia de la revolución industrial provoca graves problemas de alojamiento que necesitan ser resueltos. De este modo, antes de la I Guerra Mundial, la mayor parte de los europeos viven en verdaderos tugurios. Como es de esperar, la cocina es un lugar oscuro, insalubre y oculto capaz de albergar cualquier actividad familiar, y que en el mejor de los casos está equipado con aparadores de distinto aspecto y dimensión.

No es hasta después de la guerra cuando, gracias al poder económico de países como Alemania, Francia y Holanda, la vivienda social se convierte en la protagonista indiscutible del discurso arquitectónico promoviéndose la construcción de nuevos proyectos domésticos orientados hacia la clase media trabajadora. Desde entonces y hasta las primeras décadas de la segunda mitad del siglo XX la vivienda es objeto de nuevos proyectos con enfoques más racionales y realistas, adecuados a las necesidades colectivas del momento: es el inicio de Movimiento Moderno. 


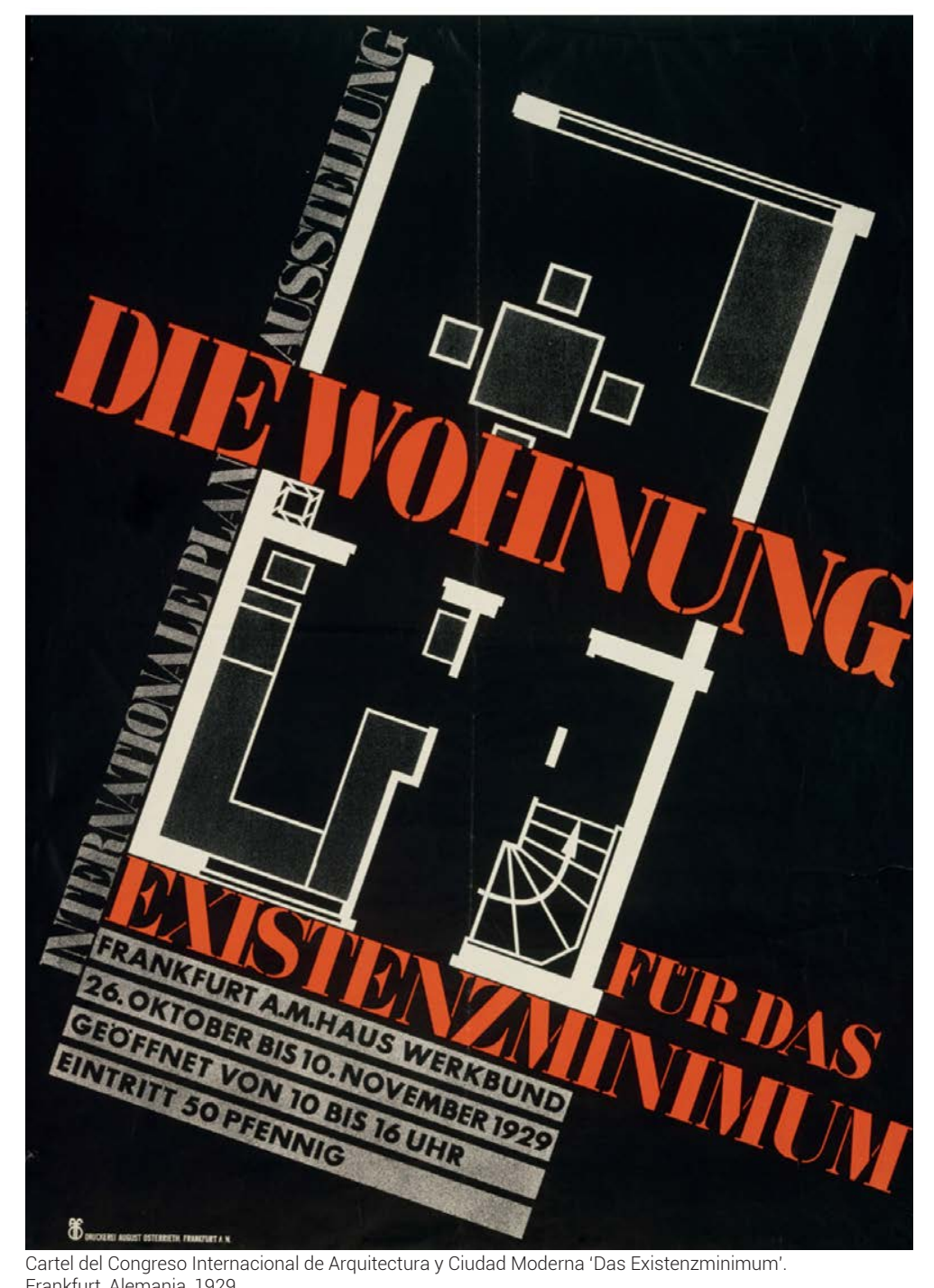

Frankfurt, Alemania, 1929.
La vivienda social Las primeras construcciones de vivienda social del Movimiento Moderno se levantan en Alemania, que aprovecha el breve alivio para su economía que supone el Plan Dawes -entre la hiperinflación de 1923 y las consecuencias de la gran depresión de 1929-. El país germano plantea que para producir viviendas económicas es necesaria una renovación tipológica. Uno de los puntos de partida de esta revisión rechaza la reproducción de los antiguos modelos burgueses y su excesiva superficie a la vez que se propone una reflexión más funcional sobre el espacio doméstico.

En 1925 el arquitecto Ernst May es nombrado director del departamento de vivienda y planeamiento urbano de la ciudad de Frankfurt. Con plenas facultades para 'combatir' la acuciante necesidad de alojamientos tras la guerra, May y su equipo construyen en cinco años cerca de 15.000 nuevas unidades de vivienda.

Lo más importante de los nuevos espacios domésticos es que están diseñados sobre la base del existenzminimun, un concepto que por primera vez considera un derecho de todo ciudadano el acceso a una vivienda de superficie mínima, pero con necesidades mínimas garantizadas adecuadas como el agua caliente, la electricidad y la calefacción ${ }^{171}$.

Entre los miembros del equipo de Ernst May se encuentra la arquitecta austriaca Margarete Schütte-Lihotzky. Educada en Viena bajo la tutela de Oskar Strnad y Adolf Loos, es la responsable de diseñar y coordinar la construcción de las cocinas de las nuevas unidades de viviendas.

La cocina de Frankfurt Una de sus primeras aproximaciones al problema del diseño de la cocina -su sistematización- consiste precisamente en la definición de qué es una buena cocina. Para ello, Schütte realiza una investigación que parte de los conocimientos de economía doméstica. A pesar de que el libro que la americana Frederick publica en 1912 le sirve como inspiración, es realmente la cocina del vagón-comedor Mitropa ${ }^{172}$ de los trenes alemanes el modelo que la arquitecta toma como referencia para su diseño ${ }^{173}$. El resultado de estas investigaciones es la conocida Frankfurter Küche de 1926

HEYNEN, Hilde. 2014.42 (del libro sqm the quantified home editado por SPACE CAVIAR 2014) era cocina y coche comedor. En una superficie de apenas 4 metros cuadrados se preparaban entre 100 y 150 comidas diarias. La comida rivaliza con la de los menús del coche eran preparados por chefs del famoso restaurante Delmonico de Nueva York. 


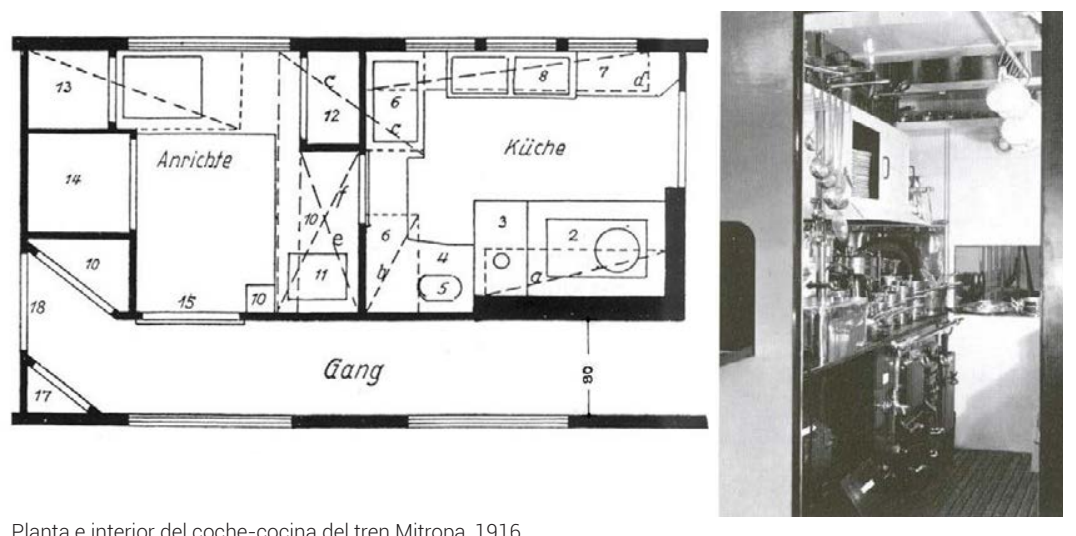

Planta e interior del coche-cocina del tren Mitropa, 1916.

46

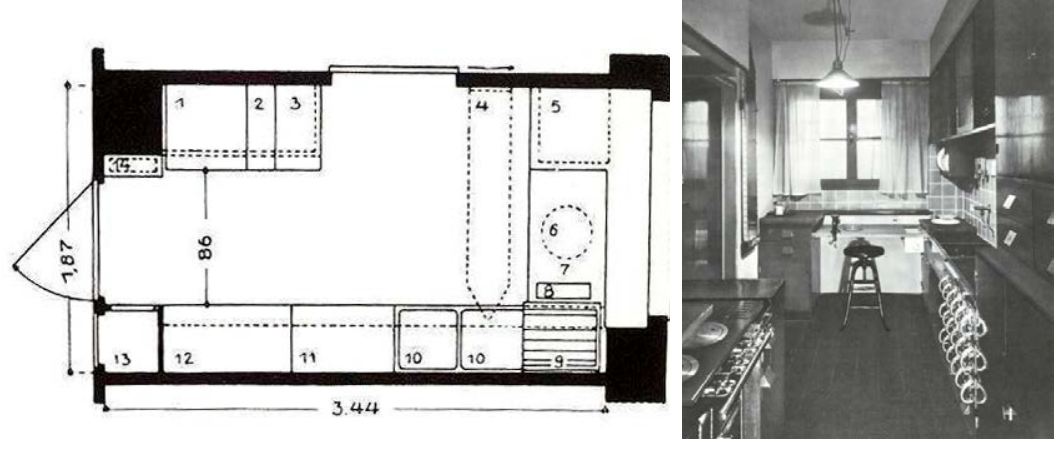

Planta de la cocina de Frankfurt, Alemania, 1927: (1) cocina de gas, (2) encimera, (3) almacenamiento, (4) tabla de

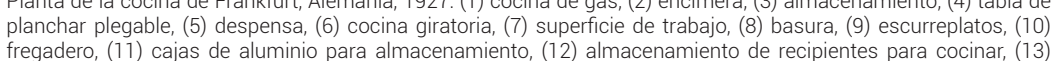
fregadero, (11) cajas de aluminio
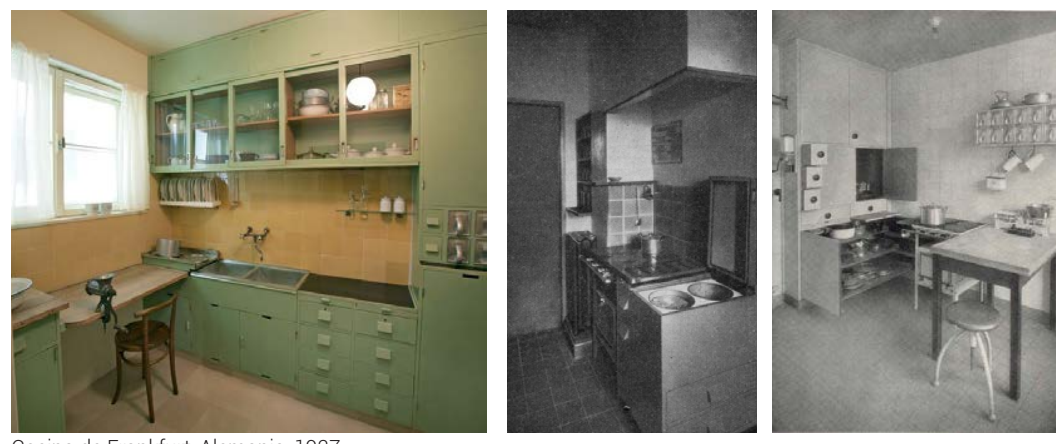

74. AICHER, Otl. 1982. 16

175 En palabras de Grette-Schütte: en primer lugar, mi trabajo consistió en considerar los principios básicos envueltos en el planteamiento y construcción de viviendas, con vistas a racionalizar la organizacion domestica. ¿Donde vivir, cocinar, comer y dormir? Esas son las cuatro funciones basicas que toda vivienda y comedor, fue rechazada bajo el argumento del coste $L$ Asi que nos decidimos por una sola unidad, compuesta de una cocina compacta e integrada, separad del salón-comedor mediante una amplia puerta corredera. Consideramos la cocina como una especie de laboratorio que, a causa del mucho tiempo que pasamos en ella, tiene que ser «hogareñam. El tiempo necesario para ejecutar las diferentes funciones fue medido usando un cronómetro, como en el sistema de (20)

177 BEE, Wilson. 2013. 43
Schütte plantea la cocina como un problema no solo técnico-labora sino también socio-cultural ${ }^{774}$. La Frankfurter Küche es la solución a un espacio que dentro de una máquina de habitar garantiza, en la mínima superficie, un funcionamiento efectivo y digno para el ama de casa. Esta cocina llega a instalarse en más de 10.000 viviendas construidas en Frankfurt entre los años 1924 y 1930

Caracterizada por la economía del gesto, este espacio de 6.5 metros cuadrados, dentro de una vivienda inferior a 90 metros cuadrados, cuenta con todo lo esencial para su óptimo funcionamiento. El tamaño reducido de esta cocina no se debe exclusivamente a motivos económicos, sino también a aspectos eficientes, ya que Schütte busca la minimización de distancias entre el armario, el mostrador, los fuegos, la mesa y el fregadero para la que sería su principal usuaria: la nueva mujer moderna ${ }^{175}$

El estudio de movimientos Frente a la desestructurada cocina tradicional, el diseño de la en la cocina Frankfurter Küche es cuidadosamente determinado a través de un estudio de los movimientos de un ama de casa que prepara la comida pone la mesa y lava los platos, como queda reflejado en un corto de que ella misma es protagonista ${ }^{176}$. Schütte se había preocupado de medir hasta el último paso necesario, de forma que se evitase cualquier recorrido que no fuera esencial.

El objetivo de estas acciones no es otro que el de facilitar el trabajo de la mujer a la vez que mejorar su posición social, ya que, supuestamente el buen diseño de la cocina de Frankfurt las 'liberaría' de su papel de amas de casa, al permitirles disponer de tiempo libre para pode desarrollar, además, una actividad fuera del hogar. Sin embargo, muchas mujeres europeas ven este cambio radical de cocina como una desventaja, ya que que el uso de la electricidad les disgusta tanto como la estética funcional moderna, prefiriendo el desorden y la confusión de sus antiguas cocinas ${ }^{177}$

\footnotetext{
Cocina de Frankfurt, Alemania, 1927
} 


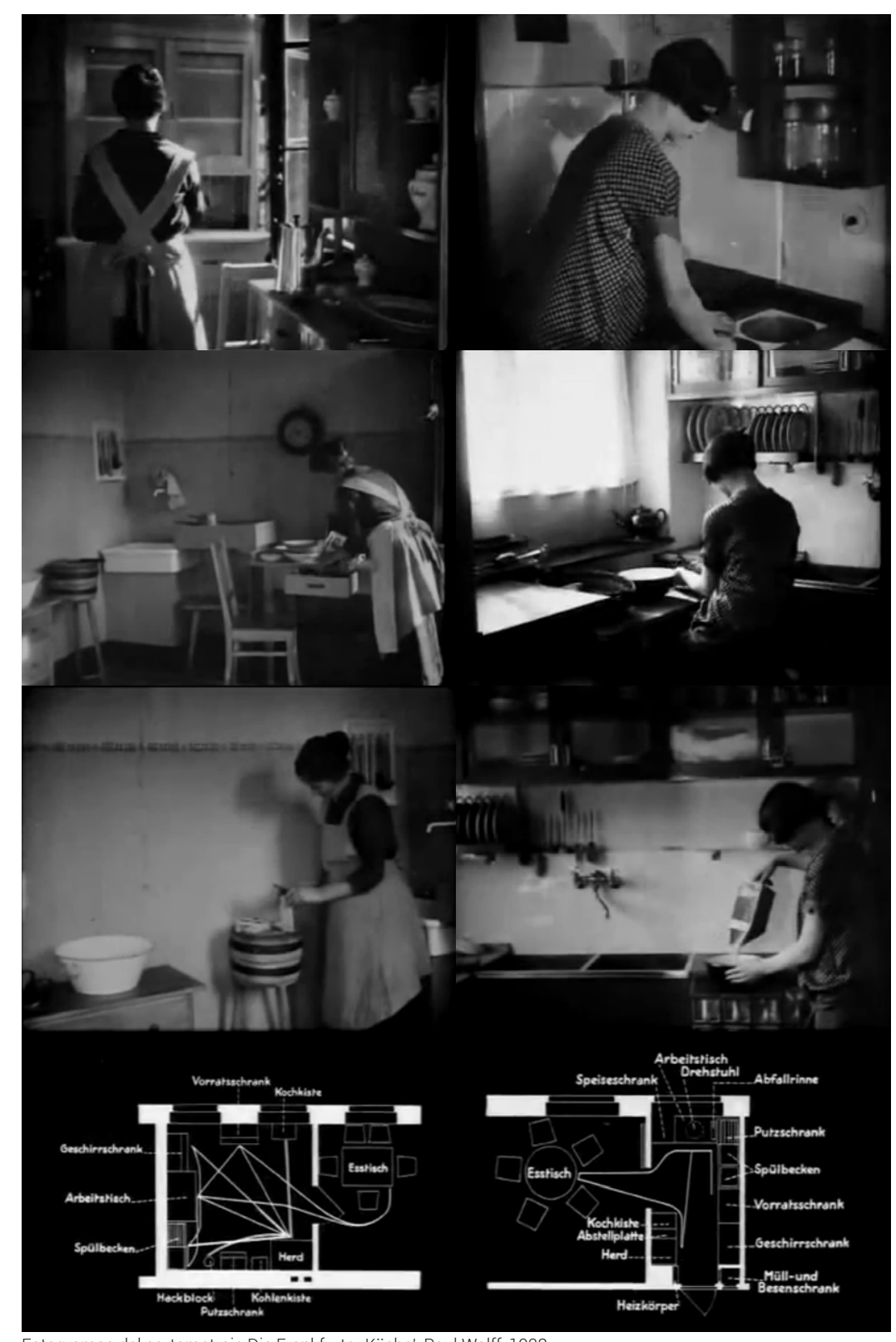

Los modos de entender la vivienda en Europa y en Estados Unidos, la forma de habitarla y el papel de la mujer quedan instaurados y representados en los espacios del cocinar; mientras la cocina de Frankfurt es coherente con la idea masculina de la casa sedentaria, como refugio y lugar de ocio, la concepción femenina de la casa americana es dinámica y basada en la comodidad.

La cocina laboratorio Frente a la cocina-taller de la antigüedad, que favorece las relaciones socio-familiares donde todos el instrumental se encuentra a la vista y se requiere de cierta pericia para su limpieza178, Schütte plantea una cocina-laboratorio dedicada exclusivamente a tareas domésticas. En ella los enseres necesarios quedan ocultos, facilitándose así la limpieza, reduciendo de esta manera el trabajo y ganando en higiene. Una solución ampliamente imitada en Europa desde entonces, y que, con ligeras modificaciones, ha llegado hasta nuestros días, especialmente en las cocinas de las viviendas sociales colectivas.

Aunque la Frankfurt Küche no es la primera cocina moderna que cuenta con muebles incorporados ${ }^{179}$, sí es la primera especialmente diseñada para ser producida en masa con un equipamiento estándar para la vivienda social. En este sentido, la simplificación espacial de la vivienda a sus necesidades básicas -dormir, cocinar, comer y lavarcoincide con una reducción funcional según el criterio de que a cada habitación una función ${ }^{180}$, conduciendo estas ideas en muchos casos a la cocina compacta. 

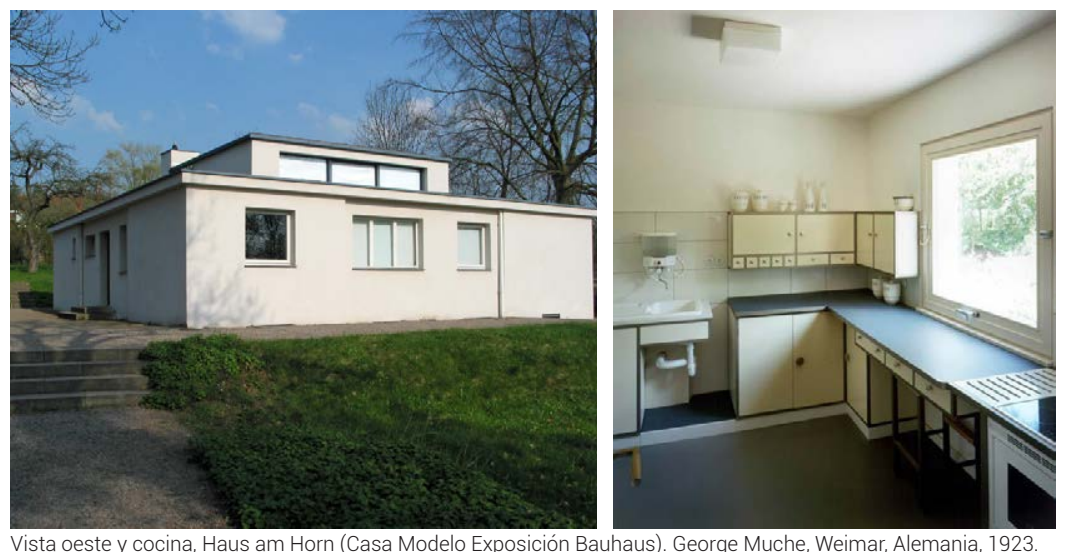

48

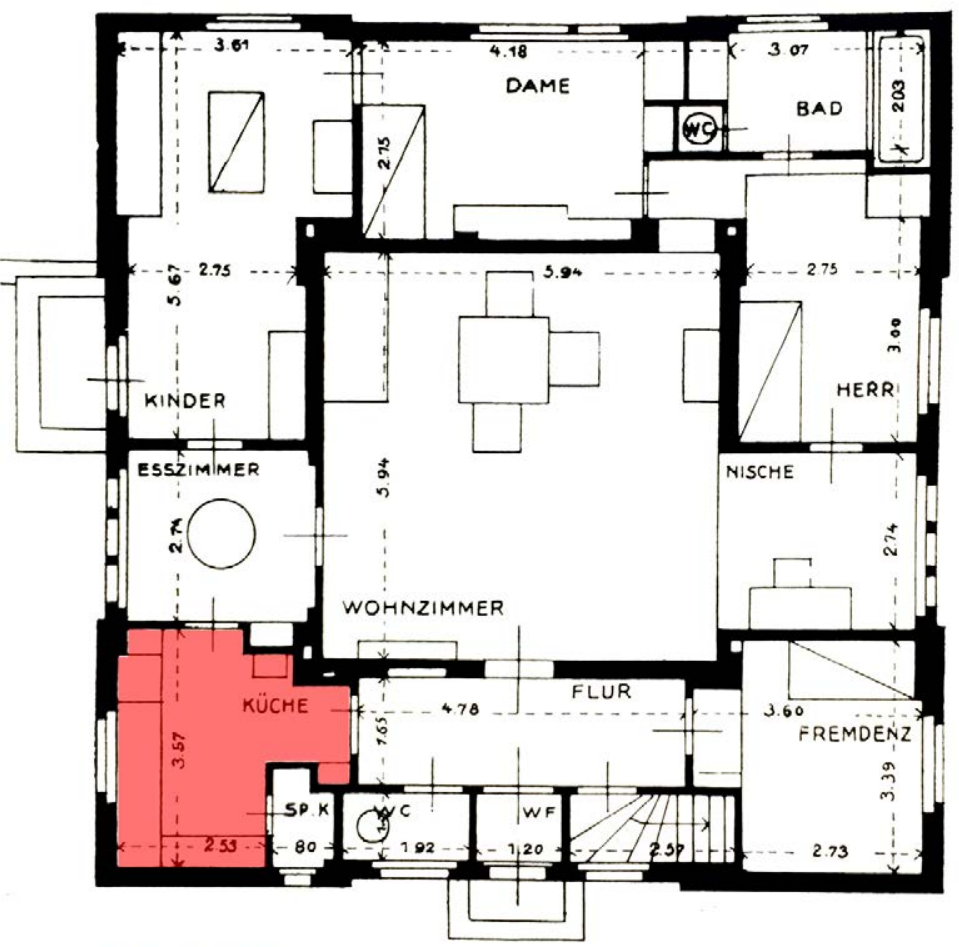

Planta general, Haus am Hom
La casa modelo Es probable que la precursora de la cocina de Frankfurt de 1926 en Haus am Horn Europa sea la de la casa modelo Dar Haus am Horn. Construida en 1923 por la Bauhaus de Weimar, esta casa, proyectada por el pintor George Muche, recoge las nuevas ideas del espacio doméstico tras la guerra. Sigue el método de trabajo en equipo propio de la Bauhaus, donde la cocina es diseñada por los estudiantes Benita Koch-Otte y Ernst Gebhardt.

La cocina tradicional de esos años en Europa viene equipada con una serie de aparadores para el almacenamiento de alimentos y menaje junto a alguna que otra mesa donde realizar las tareas de limpieza y preparación, todo ello junto a los fuegos, el fregadero y la nevera. Frente a ella, la cocina de la Casa Modelo es diseñada aplicando criterios de racionalización del espacio para facilitar el trabajo de un ama de casa que carece de servicio doméstico. En este sentido, su funcionamiento es análogo al modelo americano.

Por primera vez en Alemania, en la década de 1920 se avanza hacia una cocina compacta e integrada compuesta por distintos armarios murales de base que se disponen adosados a las paredes según una configuración de planta en L. Se define así una superficie de trabajo continua y sin juntas al mismo nivel que el fregadero y los fogones. La cocina de la Bauhaus, cuyo punto de partida es el almacenaje, es posiblemente uno de los primeros ejemplos en los que la organización va unida a la forma181.

La presencia de una ventana basculante de gran dimensión en el frente de la cocina permite entender la importancia que tanto la iluminación como la ventilación natural, principios fundamentales del higienismo de finales del siglo XIX, tienen en este espacio que durante tantos siglos permanece a oscuras y apartado ${ }^{182}$ 


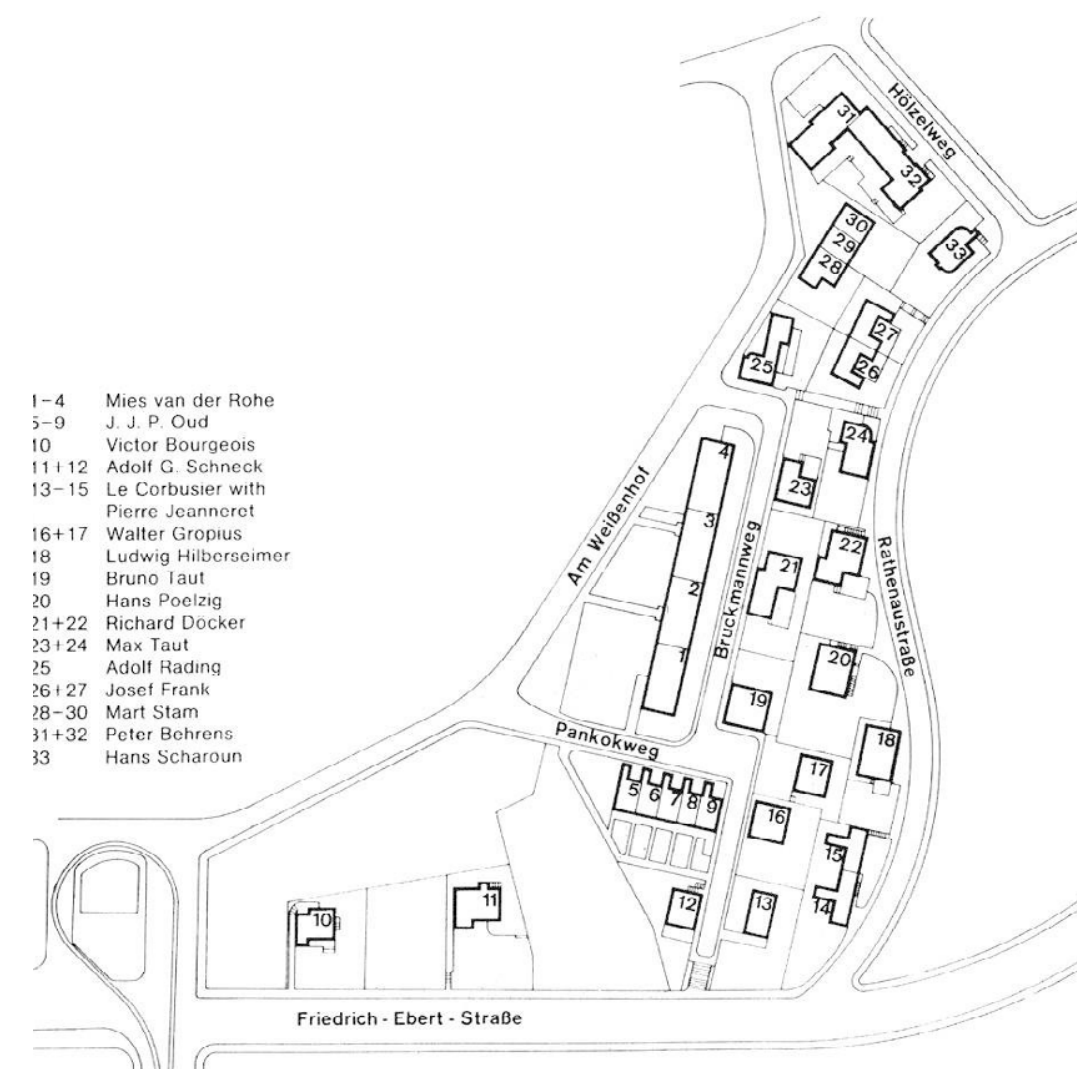

Planta del conjunto experimental de vivienda Weissenhof, Stuttgart, Alemania, 1927. (1-4) Mies van der Rohe, (5-9) J.J.P. Oud, (10) Victor Bourgeois, (11 y 12) Adolf G. Schneck, (13-15) Le Corbusier con Pierre Jeanneret, (16 y 17) Walter Gropius (18) Ludwig Hilberseimer. (19) Bruno Taut, (20) Hans Poelzig, (21 y 22) Richard Döcker (23 y 24) Max Taut, (25) Adolf Rading (26 y 27) Josef Frank, (28-30) Mart Stam. (31 y 32) Peter Behrens, (33) Hans Scharoun.

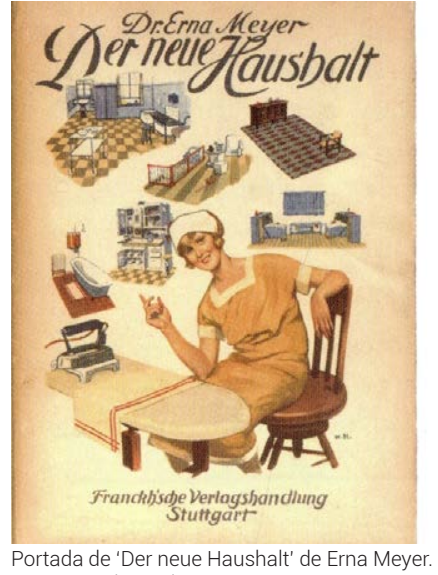

Stuttgart, Alemania, 1926

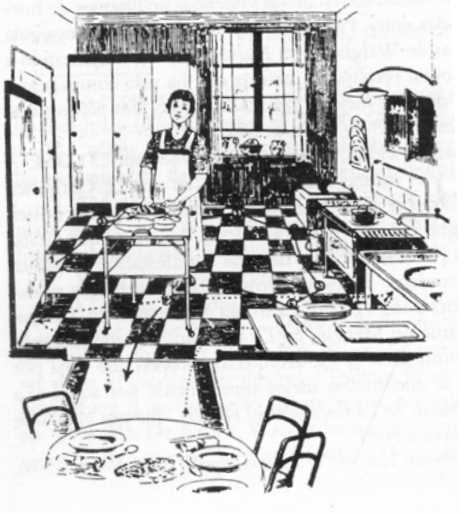

Cocina de itinerarios racion, Alemania, 1926
gar
Entre otras propuestas interesantes vinculadas al espacio doméstico que se desarrollan en el marco del Movimiento Moderno destaca la que organiza en 1927 la Deutscher Werkbund ${ }^{183}$, dedicada a la promoción de la nueva arquitectura, de la vivienda y de la industria de la construcción, con sus aplicaciones para paliar el problema de la necesidad de vivienda tras la Primera Guerra Mundial ${ }^{184}$.

La Weissenhofsiedlung La mayor aportación de esta feria es la construcción del conjunto experimental de viviendas Weissenhof -Weissenhofsiedlung- en la colonia de Killesberg a pocos kilómetros del centro de Stuttgart, siendo Mies Van der Rohe el encargado de realizar el Plan de Ordenación Urbana.

Para su realización, Mies convoca a los arquitectos jóvenes de vanguardia más relevantes del momento ${ }^{185}$ con el objetivo de obtener actuaciones singulares de viviendas, tanto unifamiliares como en bloques y viviendas pareadas o en hilera, donde promover la nueva arquitectura residencial, donde la industria de la cocina y el trabajo doméstico se convierte uno de los dos temas fundamentales.

Importante la aportación a este tema de Erna Meyer, economista alemana y teórica de la vivienda que un año antes, en 1926, publica el bestseller sobre economía doméstica The New Hosehold (Der neue Haushalt, El nuevo Hogar en castellano) ${ }^{186}$. En dicha publicación insiste en cómo las labores del hogar son un factor decisivo para la economía de un país ${ }^{187}{ }^{188}$, siendo la encargada de asesorar a los distintos arquitectos en el diseño y organización de una cocina moderna acorde con sus ideas sobre la necesidad de colaboración entre el arquitecto y el ama de casa ${ }^{189}$.
${ }_{83}$ La Deutscher Werkbund (DWB) es una asociación mixta de arquitectos, artistas e industriales, precursora de la Bauhaus, fundada en 1907 en Münich por Hermann Muthesius 184 La feria se celebra simultaneamente en dos emplazamientos distintos: por un lado, en la colonia Weissenhof; por otro, en el centro de Stuttgart, en un recinto

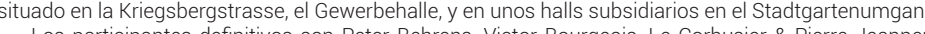

neret, Richard Döcker, Josef Frank, Walter Gropius, Ludwig Taut, Max Taut y Ferdinand Krame. doméstica y busca influencia que se publica por primera vez en 1926 y es contin 187 CORRODI, Michelle. Op. cit. 29 (dentro del libro SPECHTENHAUSER, Klaus. 2006).

En sus escritos, s importante para el todo- 'the household economy which, 189 CORRODI, Michelle. Op. cit. 29 (dentro del libro SPECHTENHAUSER, Klaus. 2006). 


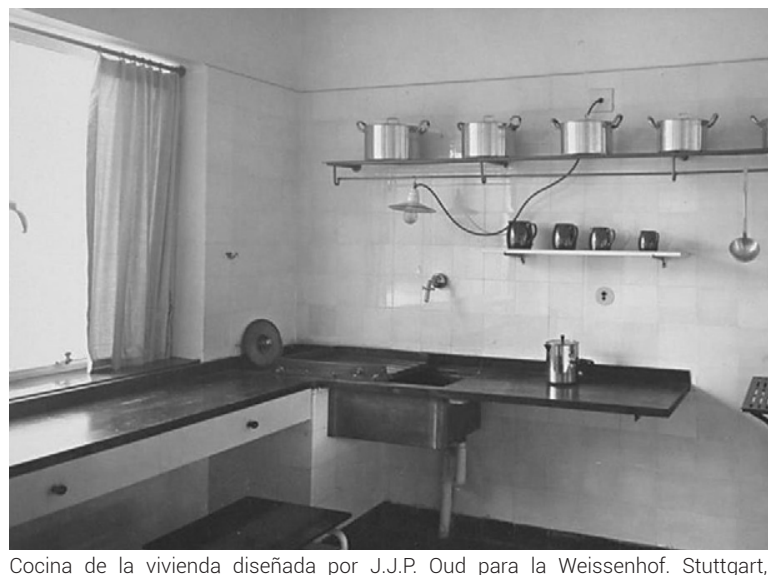
Alemania, 1923.

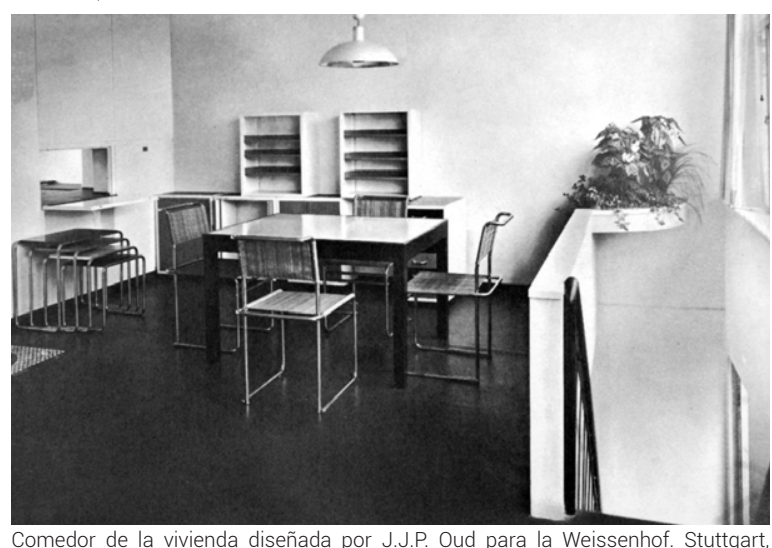
Alemania, 1923

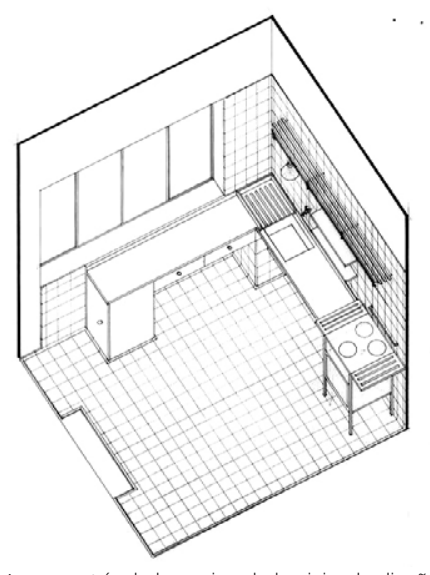
Oud para la Weissenhof. Stuttgart, Alemania, 192
Entre todas las propuestas presentadas, Erna Meyer destaca la cocina proyectada por el arquitecto holandés J.P.P. Oud. Su propuesta consiste en una configuración en $L$ donde existe una estrecha coordinación en la disposición del almacenaje, la preparaciónlimpieza y los centros de cocción, favorecido todo ello por superficies continuas bien iluminadas que bajo una amplia ventana se disponen a una misma altura. El espacio inferior de la encimera queda liberado para poder meter las piernas, lo que permite sentarse para poder trabajar con más comodidad. Esta posibilidad, sorprendentemente, no es desarrollada, permaneciendo hasta el presente la obligación de realizar las tareas de pie.

Es importante señalar la existencia de una conexión visual y auditiva con el salón a través de una ventana interior con carpintería corredera que comunica la cocina con el salón-comedor contiguo, a fin de que la madre pueda vigilar a sus hijos mientras trabaja en la cocina, pero colateralmente favoreciendo la liberación de la mujer de la cocina como recinto aislado, al margen de la vida familiar.

El Existenzminimum Dos años después de la celebración de la Weissenhof tiene lugar en Frankfurt, la ciudad donde más número de viviendas se construyen ${ }^{190}$ el II Congreso Internacional de Arquitectura Moderna (CIAM). Bajo el título Die Wohnung für das Existenzminimum, la vivienda para el mínimo existencial, el tema principal es la vivienda y la reflexión sobre la célula, su organización y su distribución ${ }^{191}$

El anfitrión del Congreso, el arquitecto jefe de la ciudad de Frankfurt Ernst May, reclama de los congresistas propuestas dibujadas para nuevos tipos de alojamiento. Es un intento por conseguir el confort máximo con parámetros económicos mínimos. En este sentido, las investigaciones en torno a la cocina de Frankfurt, proyectada tres años antes, son explicadas y aceptadas unánimemente, transformando definitivamente la manera de concebir la casa y el modo de habitar de los europeos con un modelo que se implanta prácticamente en todo el continente desde entonces. 

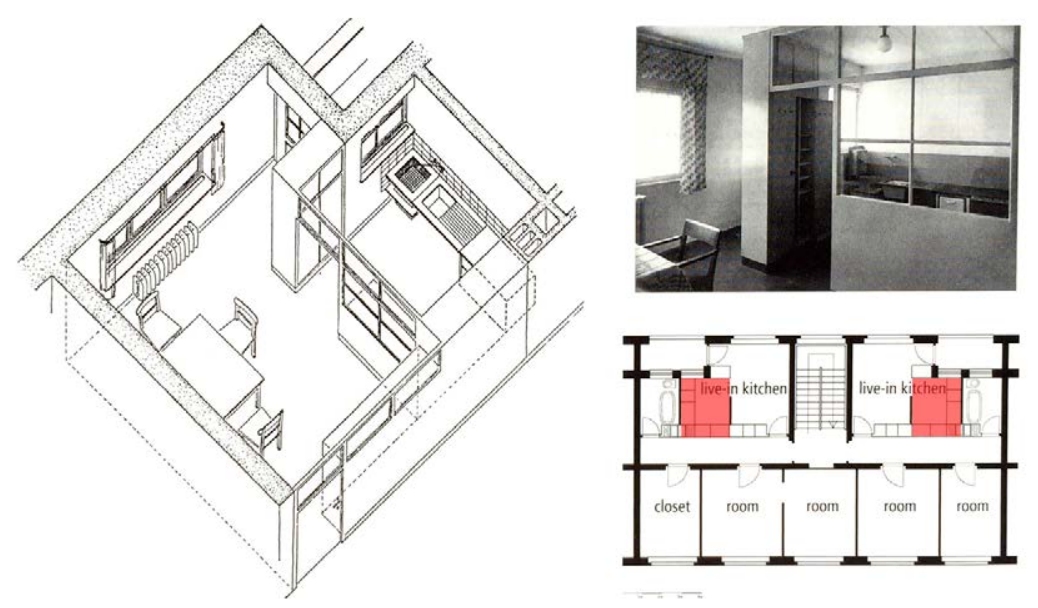

La cocina se indica en ron

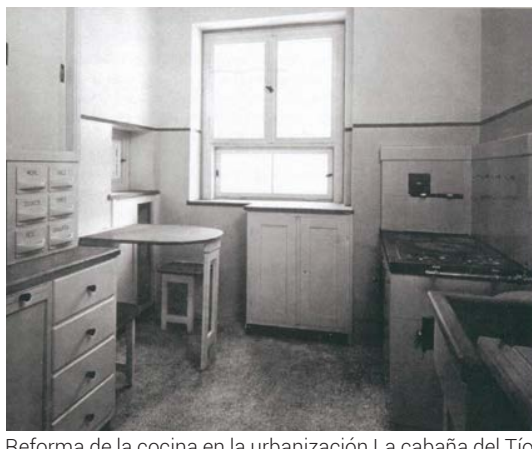

Reforma de la cocina en la urbanización
Tom. Bruno Taut, Berlín, Alemania, 1927.
Mesa de comedor y comanicado con la cocina.

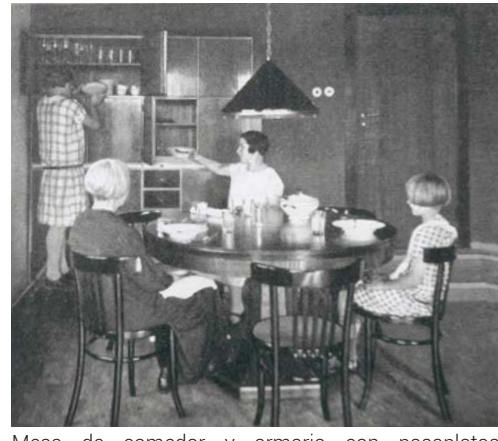

La cocina de Munich Aunquela solución de Frankfurt se impone principalmente por motivos económicos, en esta época es posible encontrar otras propuestas interesantes que ensayan diferentes grados de permeabilidad entre el modelo de cocina especializada en las tareas domésticas y comedor adjunto donde tienen muchas actividades familiares colectivas. Este es el caso de la cocina de Múnich desarrollada en 1928 por Robert Vorhoelzer y Walther Schmidt con el asesoramiento de la arquitecta Hanna Löw, en el que la cocina forma ya parte de la sala de estar. Se crea un vínculo visual entre ambos espacios mediante una puerta abierta y una gran vidriera situada a la altura de la mesa.

Otro caso interesante es el de las cocinas instaladas en las viviendas de Onkel Toms Hütte, realizadas en Berlín por Bruno Taut en 1927. Taut ensaya también diferentes soluciones para comunicar cocina y comedor tanto para facilitar el servicio de comedor como para comunicar acústica y visualmente ambos espacios. Al tiempo incorpora -aunque sea plegable o de mínimas dimensiones- una mesa o una barra donde realizar pequeñas colaciones, o bien donde mantener la atención sobre las tareas infantiles sin abandonar las ocupaciones domésticas ${ }^{192}$.

Todos estos tipos de cocinas ponen de manifiesto cómo el Movimiento Moderno supone un cambio radical en el concepto y en la calidad del espacio doméstico, siendo clave sus estudios en la evolución estructural y funcional del espacio culinario ${ }^{193}$. Por primera vez se aplican en el espacio de la cocina unos principios de organización y ergonomía que permiten un funcionamiento más racional y económico, en el que en muchos de los casos el asesoramiento y la colaboración de mujeres que introducen el punto de vista y la experiencia de la usuaria resulta fundamental, tal y como ocurre en EE. UU. años antes.

Esta desincronización aparente del progreso del espacio doméstico entre ambos continentes hace que mientras que la cocina pionera europea de los años veinte es muy sencilla, con poco mobiliario y apenas equipamiento, en la misma época la cocina americana se va complejizando y, sobre todo, diversificando. 


\section{DE STANDARDISATIE E UBE}

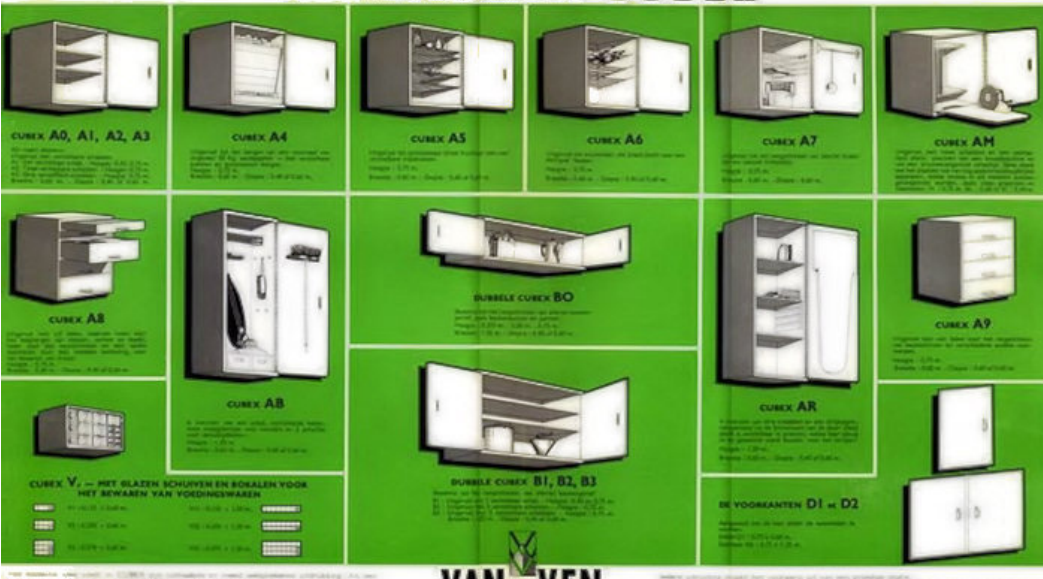

VANDEVEN

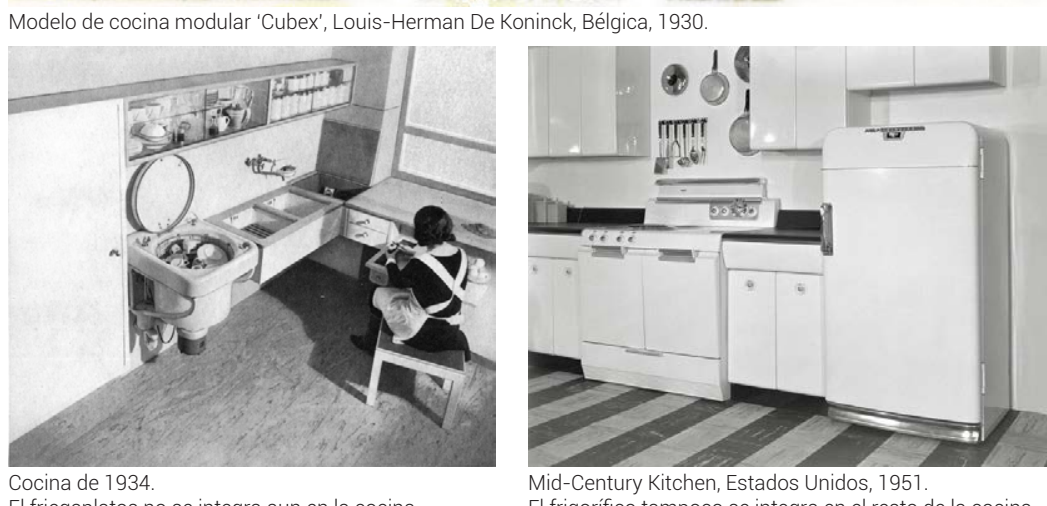

El friegaplatos no se integra aun en la cocina.
La estandarización del mobiliario de cocina de alimentos como una acumulación de piezas individuales. Desde entonces el armario-alacena organizado se va sustituyendo, poco a poco, por unidades de almacenaje estandarizadas que en un primer momento son vendidas por las firmas de ventas de correo ${ }^{194} 195$ Gracias a este sistema, y por primera vez, el mobiliario de cocina se adapta a las opciones espaciales y económicas más diversas de cada hipotético cliente.

Además, junto a los fabricantes de muebles, en la misma época la industria de los aparatos eléctricos se manifiesta tan deseosa como la primera de introducirse en la cocina.

La mecanización de la Al notable avance técnico de cocinas eléctricas y de gas se unen cocina para la total mecanización de los trabajos de la cocina, otros aparatos que en cierto modo proponen soluciones más novedosas que las de las propias fuentes de calor. Se trata de las labores anexas y complementarias a todo proceso culinario que incluyen el almacenamiento de alimentos perecederos, la manufactura y elaboración de productos, el lavado y secado de los útiles, platos y cubiertos que se utilizan, y el lavado y planchado de la ropa de la casa $^{196}$.

El frigorífico Sin duda los aparatos frigoríficos son, posiblemente, una de las aportaciones más importantes y definitivas que transforman por completo la organización culinaria. Trastocan los hábitos de abastecimiento, alimentación y preparación y, en consecuencia permite estructurar el espacio de una manera compacta y racionalmente funcional.

Sin embargo, entre los fabricantes de mobiliario y las compañías de gas y electricidad no existe coordinación alguna. De esta manera cada elemento de la cocina tiene una dimensión distinta, dando como resultado un espacio culinario con un equipo heterogéneo, funcional y estilísticamente, que plantea un claro problema de organización.
New Kitchen

Built to Fit

Your Wife

Gardner SOULE. New kitchen built to fit your wife en Popular Science. Septiembre 1953. El desarrollo de la cocina
194 GIEDION, Sigfried. Op. cit. 605-606 

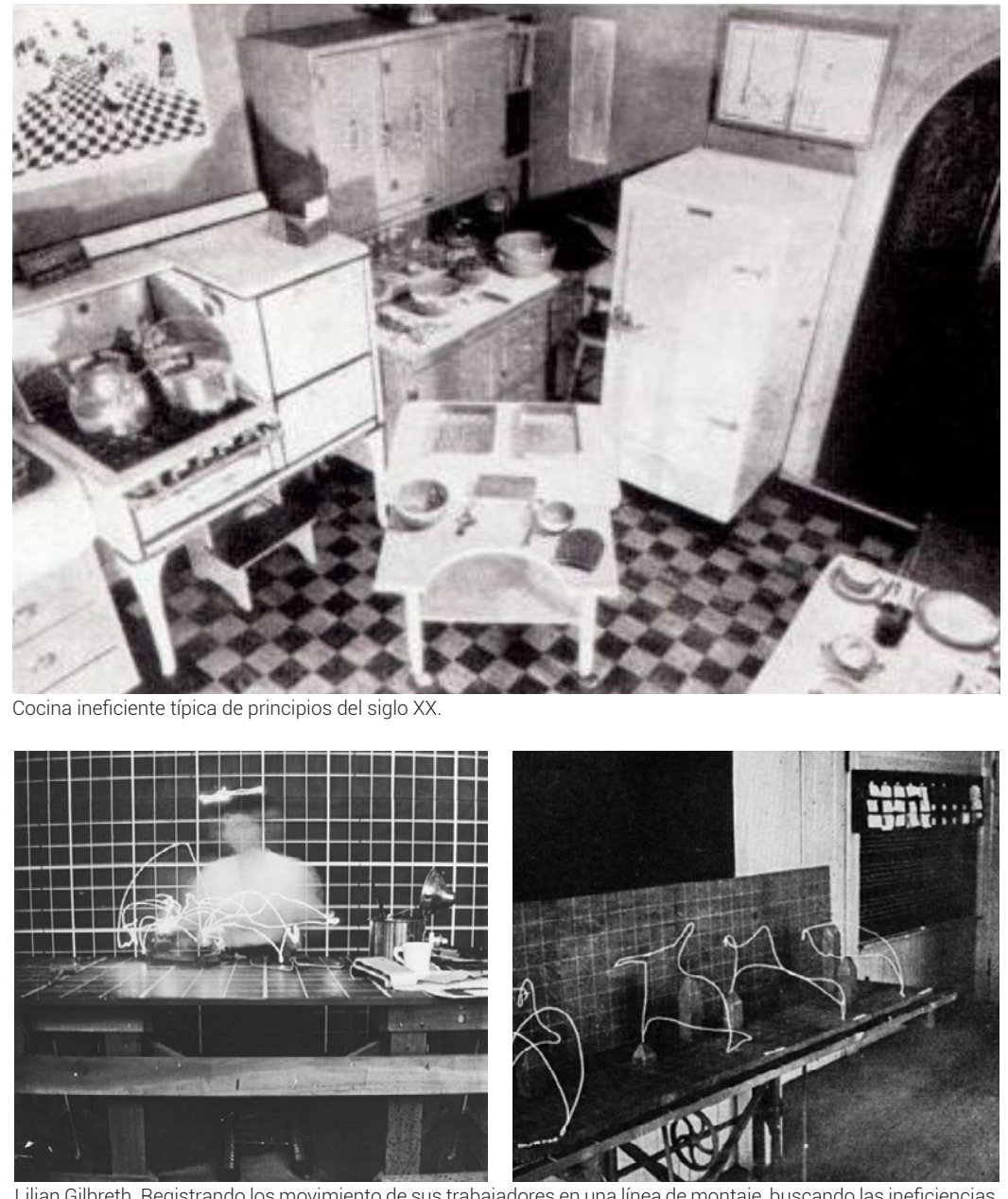

Ante este caos morfosintáctico dentro de la cocina, los primeros intentos de la industria americana para disponer la miscelánea del equipo y el mobiliario en una forma unitaria y coherente y racionalizar el trabajo de cocina aparece en 1930'97. Sucede cuando la compañía de Gas de Brooklyn contrata a la ingeniera de producción Lilian Gilbreth para realizar un estudio de movimientos en una cocina de 3 x 3.65 metros mediante la reducción del espacio entre los distintos elementos del equipamiento de la cocina ${ }^{198}$.

Sin duda Gilbreith, influida por su marido, el ingeniero padre del eficientismo Frank Gilbreith, aporta en este estudio nociones sobre los tiempos, movimientos y programación de etapas, como análisis de flujo y micro movimientos en las tareas domésticas, mejorando enormemente la productividad, la racionalización y la organización de la cocina.

Los estudios de Gilbreth se ven reforzados por firmas americanas como General Electric o Westinghouse, cuando entre 1932 y 1934 abren instituciones de cocina que reúnen a ingenieros, químicos, arquitectos nutricionistas y cocineros profesionales que aplican una aproximación multidisciplinar de carácter científico a la problemática de la cocina y la integración de los electrodomésticos.

La Streamlined Kitchen Como resultado, a finales de la década de 1930, se presenta un modelo de cocina de proceso de trabajo organizado que fusiona la arquitectura, el equipamiento y el mobiliario, hasta entonces concebidos como unidades distintas. Es la denominada Streamlined Kitchen ${ }^{199}$, la cocina modular que integra muebles altos y bajos y electrodomésticos integrados y estandarizados que pueden combinarse de muchas maneras y que entiende, por primera vez, la organización de la cocina como un todo. La cocina modular no es otra cosa que la traducción del pensamiento de ciertas mujeres norteamericanas en términos de producción industrial. 


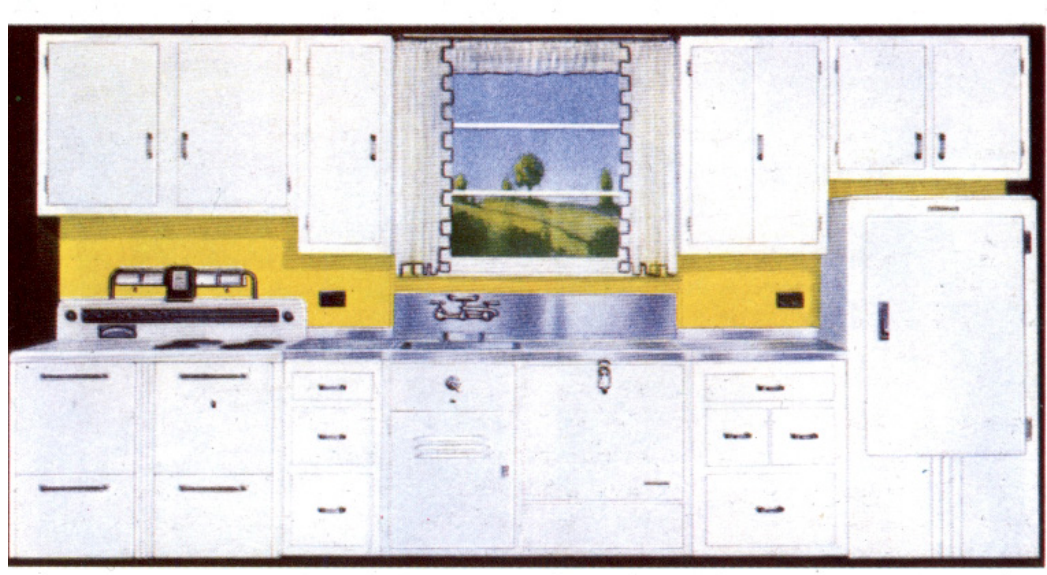

Cocina modelo Westinghouse . Colección Baltimore Gas and Electric Company. Estados Unidos, 1930.

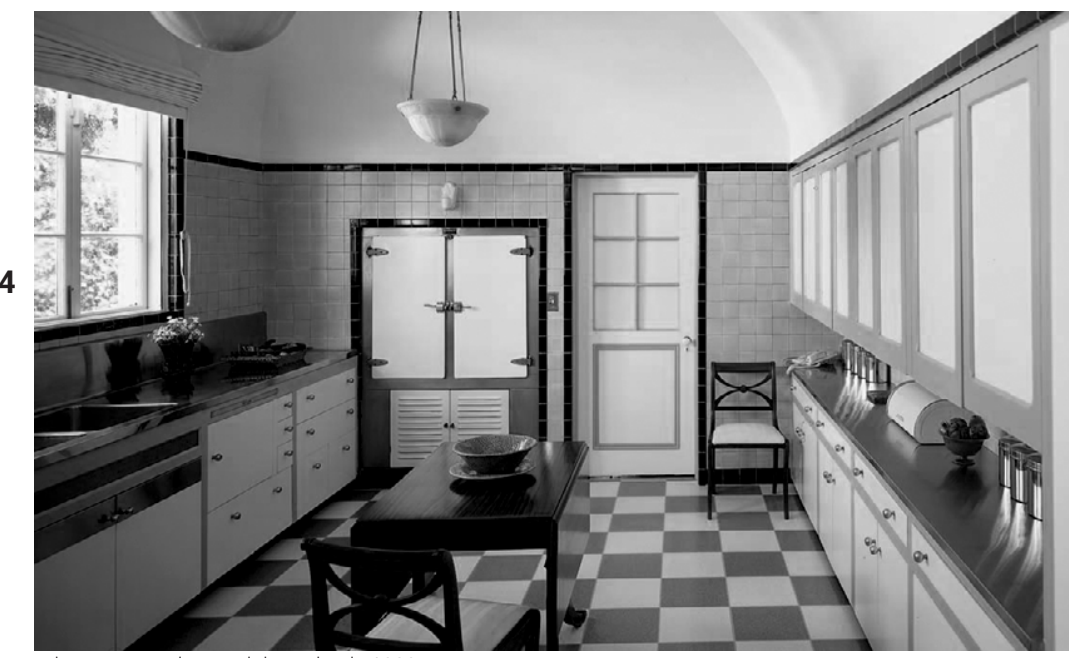

La Streamlined Kitchen es una nueva instalación fija que aspira a integrar los armarios y equipos en un organismo coordinado y continuo sin fisuras: pila, cocina y mostradores forman una superficie de trabajo de una sola altura mientras los armarios de pared se establecen en un plano paralelo pero independiente.

El esquema de diseño es el mismo para todos los fabricantes: una superficie continua y al mismo nivel une todos y cada uno de los procesos de trabajo. El frigorífico y los fuegos son los únicos aparatos que no se integran de manera total en el conjunto de la cocina continua, puesto que su altura y profundidad no coinciden con la de los otros aparatos. Hace falta esperar hasta 1945 para llegar a un acuerdo como el que se produce en Estados Unidos entre veinticinco fabricantes de aparatos a gas y ocho industriales de armarios de cocina para establecer las dimensiones finales de la cocina 200.

Como en una fábrica moderna, el objetivo de la cocina continua es permitir la realización de una serie ininterrumpida de tareas a través de una secuencia de puestos de trabajo especializados. Sin embargo, como señala Lupton, la labor realizada en esta fábrica se centra en e consumo y no en la producción ${ }^{201}$.

La normalización de la El cuerpo del ama de la casa americana es el modelo que se toma como referencia para establecer las dimensiones de los muebles de cocina y electrodomésticos, para su estandarización, normalización y regularización. La profundidad de las superficies de trabajo queda fijada en 62.5 centímetros, con el fin de acomodar esta medida a las lavadoras automáticas, el lavavajillas o las cocines-compact; la altura de trabajo de la encimera desde el pavimento hasta la superficie de trabajo es de 90 centímetros ${ }^{202}$ 

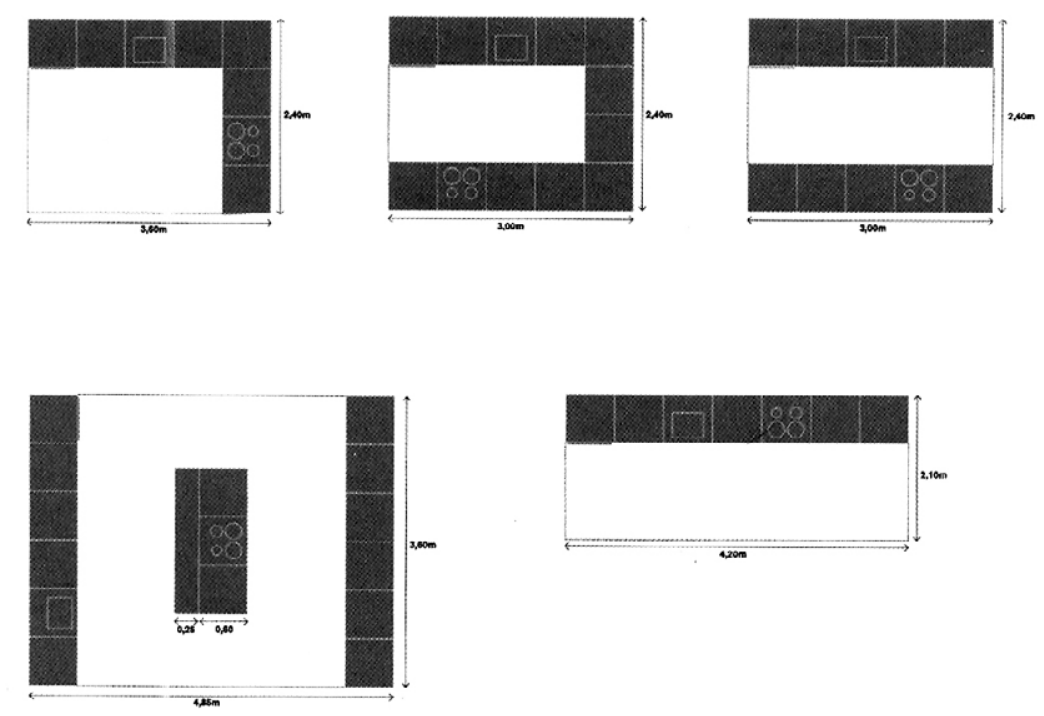

Distribuciones del modelo de cocina europea normalizado: en L, en U, en paralelos, cocina con isla y en línea.

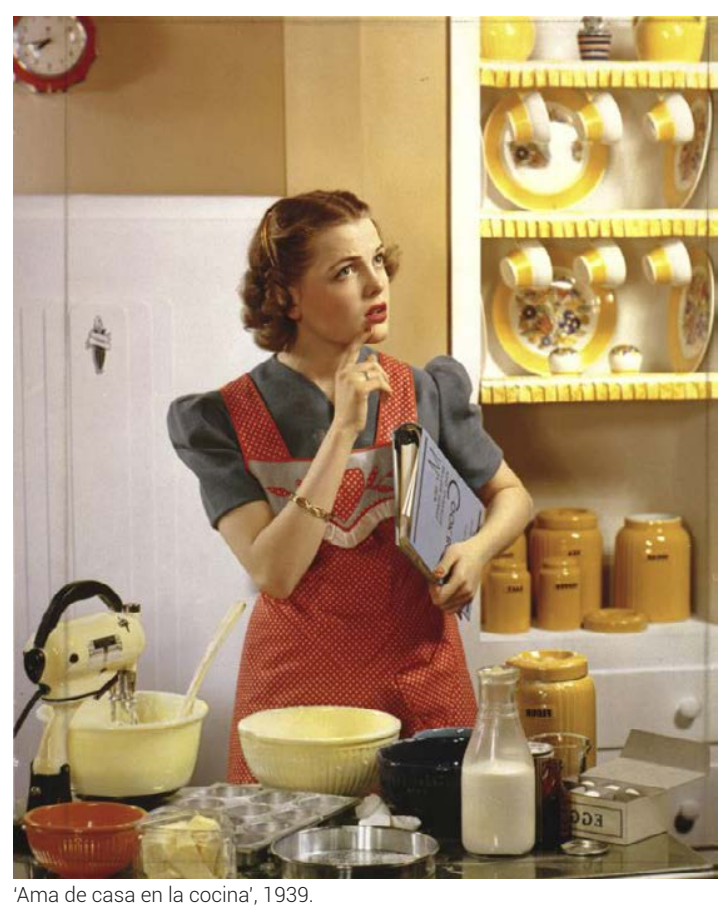

Mientras, en Europa, la mayor parte de las cocinas todavía están configuradas con muebles y electrodomésticos independientes. El espacio de preparación de alimentos está compuesto por superficies de trabajo parcialmente continuas, hechas a base de piezas aisladas de mobiliario de cocina. Además, los fogones no encajan en las unidades circundantes ni están integrados en el proceso de trabajo.

No es hasta después de la Segunda Guerra Mundial cuando las propuestas y soluciones de la cocina modulada americana llegan al otro lado del Atlántico, a través de revistas y exposiciones que las adaptan a los diseños europeos.

La cocina modular Una vez que la cocina europea se normaliza, las opciones de y sus tipos configuración de los fogones, el fregadero y los armarios reducen a seis los tipos de este espacio: a lo largo de una pared (de forma lineal), distribuidos en dos paredes (en pasillo), en forma de $L, U, G, y$ concentrados en una isla. Una situación que sin duda será criticada por algunos arquitectos, que señalan cómo estos tipos de cocina definidos limitan el campo de elección y disminuyen aún más la posibilidad de control del arquitecto ${ }^{203}$.

La expansión de la cocina integrada - vinculada a la estandarizaciónes el inicio de la democratización del espacio culinario en un proceso que triunfa precisamente porque su diseño está ligado a conceptos como nuevo, moderno y avanzado, donde una de las grandes ventajas se basa en la reducción de las tareas domésticas gracias a un equipamiento negociado en base a directrices ergonómicas y principios de gestión del trabajo racional.

Sin embargo, la realidad es que antes de la Segunda Guerra Mundial, y a pesar de la mecanización, la mujer en el hogar sigue siendo la principal responsable tanto de las tareas domésticas como del cuidado de los habitantes. Hay que esperar hasta después de las revoluciones de género, en la década de 1960, cuando esta situación cambie. 



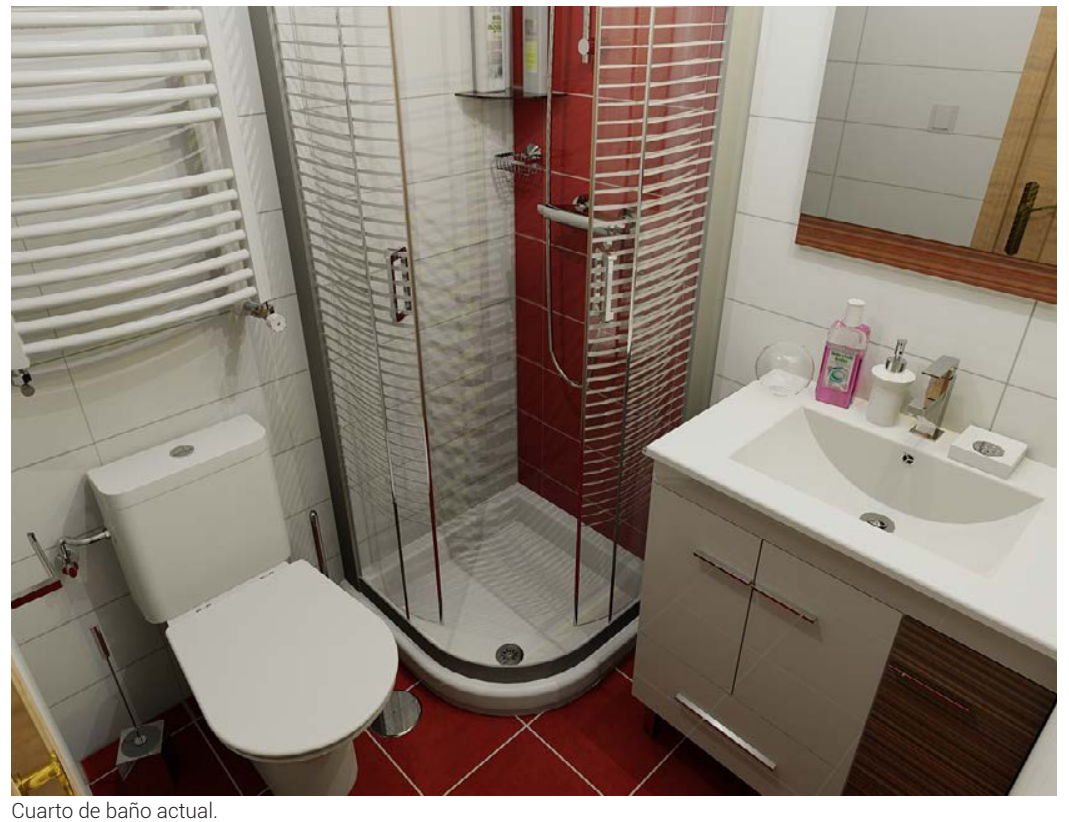

58

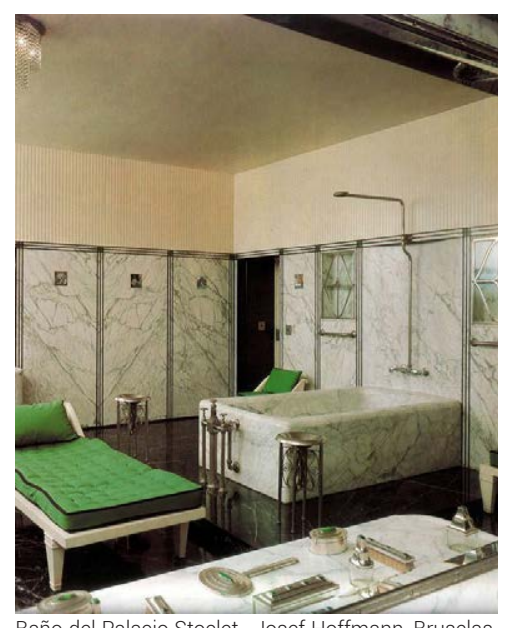

Bélgica, 1905-1911.

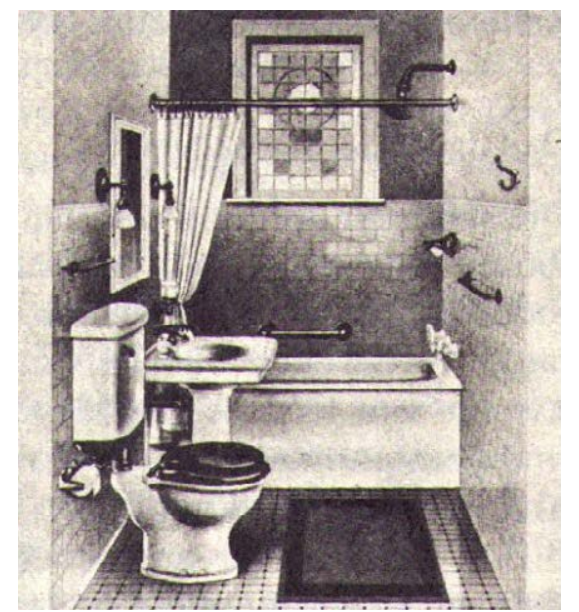

Baño de 1915 .
¿Cuarto de baño? ¿A qué nos referimos cuando hablamos del cuarto de baño? Sin lugar a dudas, este conjunto de tres términos, tan cotidiano como asumido por las sociedades desarrolladas, nombra un espacio confuso, ambiguo y lleno de eufemismos en torno al mantenimiento del cuerpo que resulta difícil de definir. El cuarto de baño, tal y como lo conocemos en España en la segunda mitad del siglo XX y todavía vigente en muchas viviendas actualmente, es un ámbito lleno de significados, aunque fijado en el imaginario colectivo como una habitación generalmente utilizada para el aseo personal, el baño y la evacuación de los desechos humanos donde los elementos más habituales son una bañera y/o ducha, un inodoro, un lavabo, un bidé -dependiendo del país- y un espejo?

Esta definición bien puede coincidir con la descripción del primer cuarto de baño doméstico que aparece en Europa, en torno a 1880 en la vivienda burguesa de Inglaterra² , si no fuera porque este nuevo espacio, de grandes dimensiones y ostentosamente amueblado como cualquier otra habitación de la casa ${ }^{3}$, se identifica más con un artículo de lujo que con una necesidad, en un momento en el que el hábito de la limpieza diaria es algo inimaginable.

Simultáneamente a este cuarto de baño burgués, la célula-baño doméstica americana, que recibe su impulso de los hoteles de finales del siglo XIX, también se puede reconocer en esta primera definición. Más pragmática, eficiente y reducida que la versión europea, en parte debido a una ausencia de carga cultural e ideológica del país ${ }^{4}$, el modelo americano lidera, desde su democratización en la segunda década del siglo XX, el desarrollo del cuarto de baño 5 .

Sin embargo, hasta convertirse en el espacio común de protegida intimidad, tal y como lo conocemos hoy en día, el cuarto de baño, si es que puede llamarse así, recorre un largo camino que en cierta medida es un tránsito de lo público, colectivo y visible a lo privado, individual y oculto. En su formación están implicados, además de factores sociales, culturales, morales y económicos, tanto la ideología respecto al cuerpo de cada época como la tecnología disponible del momento. 


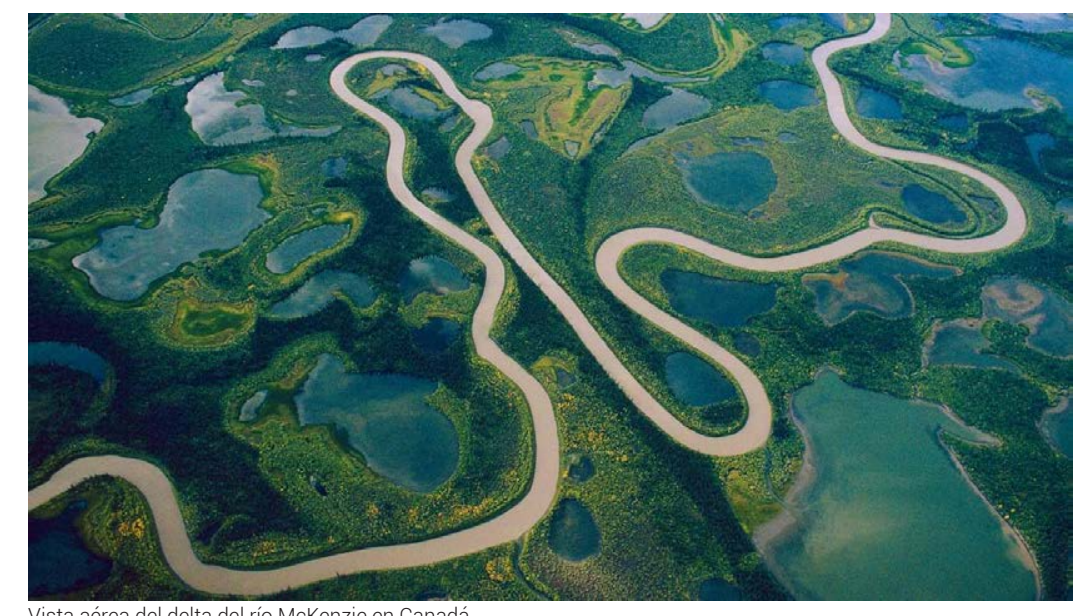

El río como primer planteamiento sanitario de la historia.

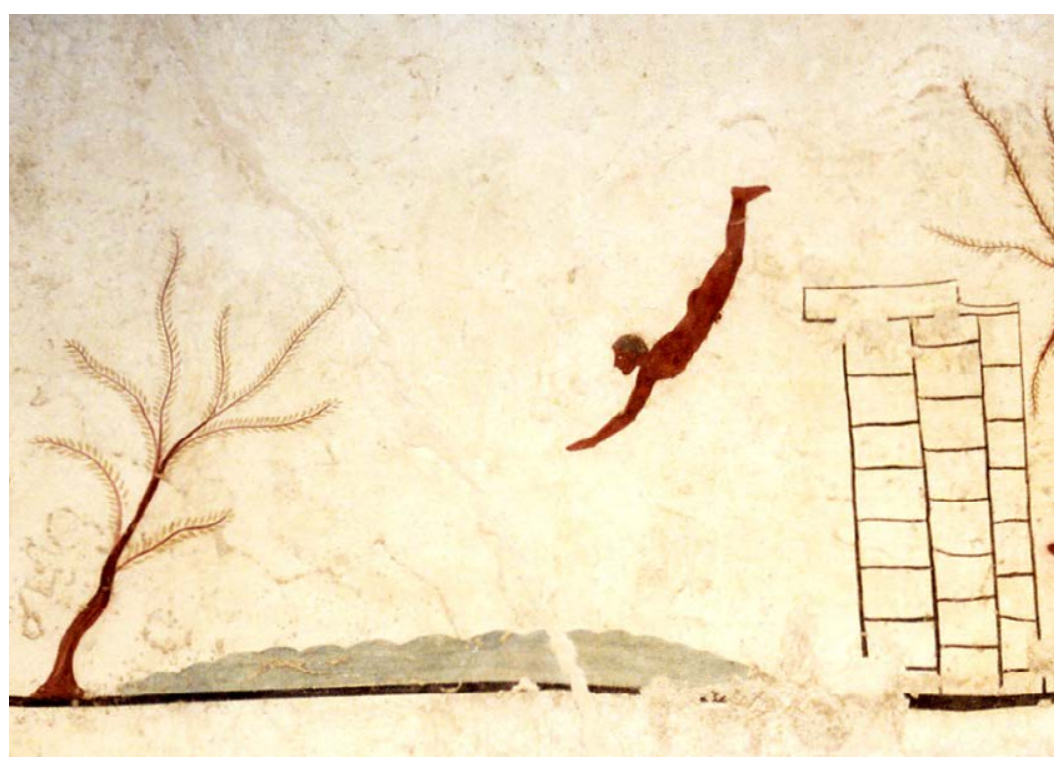

Pintura de la losa del frente de la tumba del Nadador, Paestum, Italia, hacia el 480 a.C.
Desde los orígenes, el instinto de supervivencia, inherente tanto a los animales como a los seres humanos, les impulsa a alimentar y a cuidar el cuerpo con el fin de mantenerlo en las mejores condiciones durante el mayor tiempo posible. Para este cuidado, el agua, un bien tan preciado como necesario para la vida, se convierte en el medio fundamenta

El baño natural De este modo, parece razonable pensar que, ante la ausencia de medios para transportar el agua, las primeras moradas paleolíticas se construyan al borde de los ríos y los arroyos, que constituyen el lugar donde se unen, por primera vez, el lavado del cuerpo, la eliminación de materias orgánicas ${ }^{6}$ y el suministro de agua para beber ${ }^{7}$.

La corriente del río pronto organiza y jerarquiza topológicamente estas actividades a lo largo de su recorrido: mientras que la parte superior se reserva para beber agua y 'lavarse', en la inferior se realizan las funciones de eliminación, iniciando el planeamiento sanitario.

De nómadas a sedentarios Miles de años después, cuando el ser humano abandona la orilla del río por falta de espacio, en busca de combustible y caza, haciéndose sedentario, la eliminación de los desechos orgánicos se convierte en un problema.

Dependiendo de los hábitos alimenticios de cada cultura y la salud de las personas, cada veinticuatro horas expulsamos de nuestro cuerpo una media de 1.3 litros de orina, 475 litros al año, y entre 130 y 160 gramos de materias fecales, lo que representan de 47 a 58 kilos al año, respectivamente.

Es precisamente esta producción natural, imposible de reducir, que crece regularmente a medida que aumenta una población, lo que conduce a cada civilización a proponer distintas estrategias para su eliminación o su aprovechamiento. En todas ellas, tanto el sentido de la vista como del olfato juegan un papel decisivo a lo largo de la historia. 
El transporte del agua Por otro lado, lejos de los ríos, uno de los mayores problemas a los que se enfrenta el ser humano es el transporte de agua. Esta se convierte en un bien escaso y valioso que se prefiere administrar para beber y cocinar antes que para el baño, haciéndose esta práctica cada vez menos frecuente ${ }^{10}$.

El agujero en la tierra como Ya en el Antiguo Testamento, el libro del Deuteronomio (Dt. 23, 13primer inodoro 15) ordena en el capítulo de las leyes sanitarias que las necesidades naturales no solo deben realizarse fuera del campamento de guerra, sino que también hay que enterrarlas ${ }^{11}$. De este modo, la doctrina cristiana, que ve la materia fecal como algo impuro -y que paradójicamente se genera en el interior de nuestro cuerpo-, es posiblemente la responsable de la aparición del primer inodoro.

La ocultación del residuo Si bien en un principio la principal preocupación, más que la presencia del desecho orgánico, es su olor ${ }^{12}$, con la llegada de las primeras civilizaciones la situación se invierte. Desde entonces, y durante mucho tiempo, la expulsión de esta materia se realiza en el exterior en un lugar alejado del espacio vital, de los sitios donde se come, se duerme y se reza, con el fin de mantenerlo limpio, puro e inodoro.

No es hasta que una civilización está lo suficientemente desarrollada bien porque dispone de esclavos o porque cuenta, en el mejor de los casos, con la tecnología necesaria para conducir el agua, que aparece un incipiente baño doméstico para que las funciones de eliminación se realicen en un espacio protegido -templo, edificio o vivienda-.

Exceptuando a los egipcios, sumerios y tartesos, las primeras civilizaciones social y tecnológicamente avanzadas son las grecorromanas. Además de contar con numerosos servidores que entran en la categoría de instrumentos para la acción ${ }^{13}$, son los primeros pueblos que disponen tanto de conducciones subterráneas como de acueductos repartidos por todo el territorio que facilitan los hábitos de limpieza corporal y evacuación. han tenido que buscar y transportar agua ha fomentado el bañarse en ella. (WRIGHT, Lawrence. Op.cit. 26).

政 desto porque el Señor tu Dios anda en medio de tu campamento para protegerte y darte la victoria sobre tus enemigos. Por eso tu campamento debe ser un lugar sagrado, y si él ve alguna cosa que

le desagrada dejará de acompañarte.
12 Aunque a lo largo de la historia se ha demostrado ampliamente que los sentidos de la vista y el olfato han sido los que han determinado gran parte de nuestros patas, situándose en el mismo plano la nariz y el ano el sentido del ol fato adquiere una gran importancia No es hasta que los humanos se yerguen y consiguen 13 ARISTÓTELES. Ética Nicomáquea. 213. 

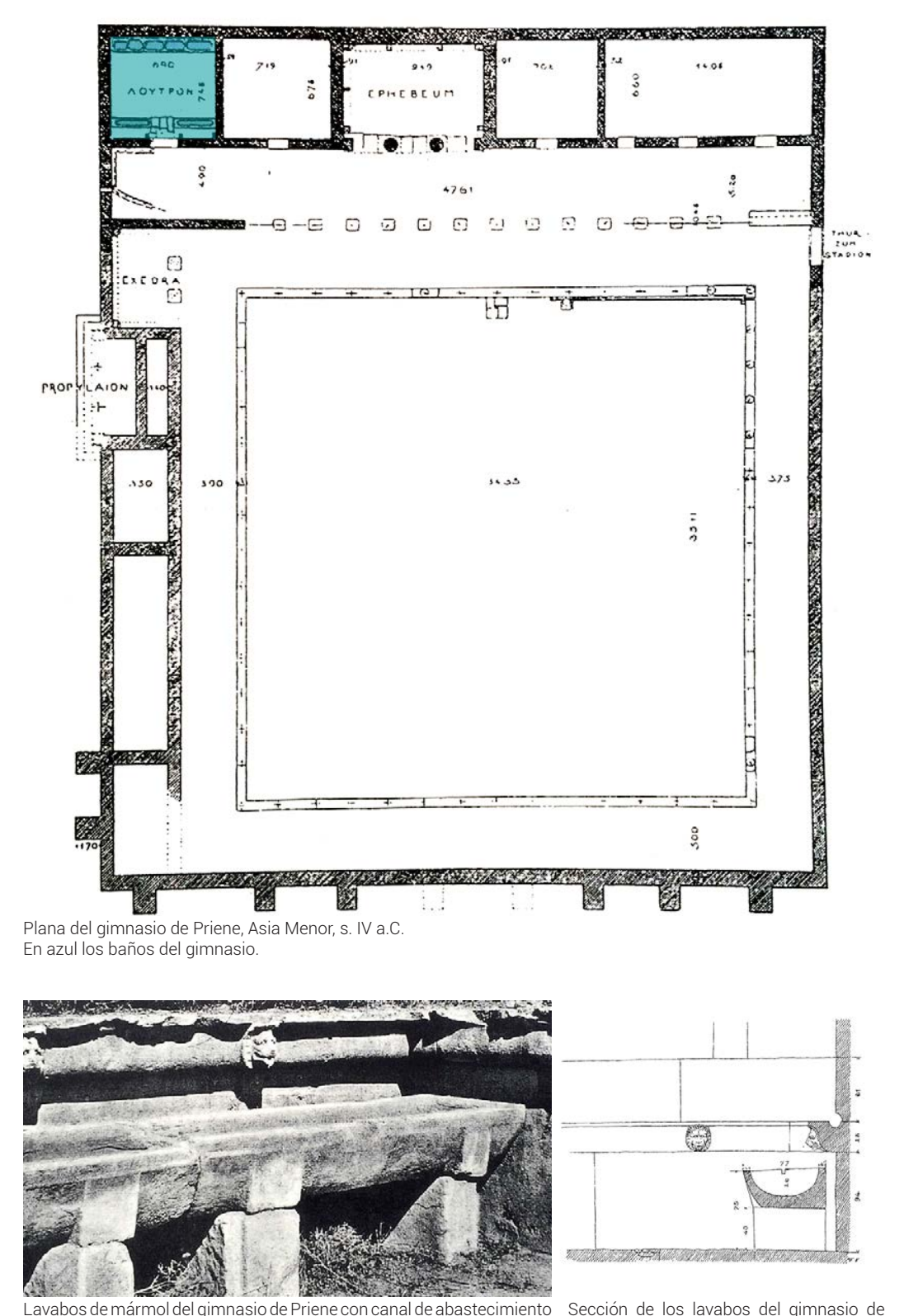

Lavabos de má
visto, s. IV a.C.

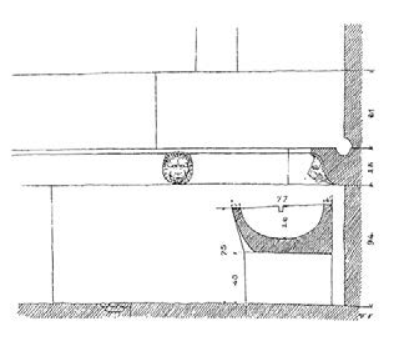

Sección de los
Priene, s. IV a.C.
La configuración de las ciudades-polis grecorromanas, frente a las de las ciudades-estado de las civilizaciones antiguas, influye en as costumbres de sus habitantes y favorece que, por primera vez, tanto la limpieza corporal como la evacuación adquieran un carácter público y social.

Los grandes núcleos urbanos ejercen un creciente poder político y socioeconómico sobre la ciudad y sus alrededores, que llega a formalizarse en una serie de edificios públicos. De esta manera, acrópolis, ágoras, circos o teatros se convierten en los principales componentes de toda ciudad grecorromana, que visibilizan el alto sentido de lo social.

Los baños públicos En este contexto, tanto el aspecto cultural de la limpieza corporal como comunitarios el material son una responsabilidad totalmente pública. Los baños se ubican en una edificación de uso comunitario alejando cualquier posibilidad, salvo excepciones ${ }^{14}$, de su inclusión en la vivienda.

Los baños públicos en Grecia son tan solo una dependencia del gimnasio, una instalación en donde se practican ejercicios corporales, además de ser la célula donde germina el desarrollo intelectual y físico bajo el lema mens sana in corpore sano. La operación del bañarse, que se concibe como medio para reparar fuerzas, se efectúa por procedimientos elementales: son simples inmersiones y duchas, cortas y frías ${ }^{15}$, que, centradas en la educación física y espiritual de la época, están más destinadas a los atletas que a la población. 


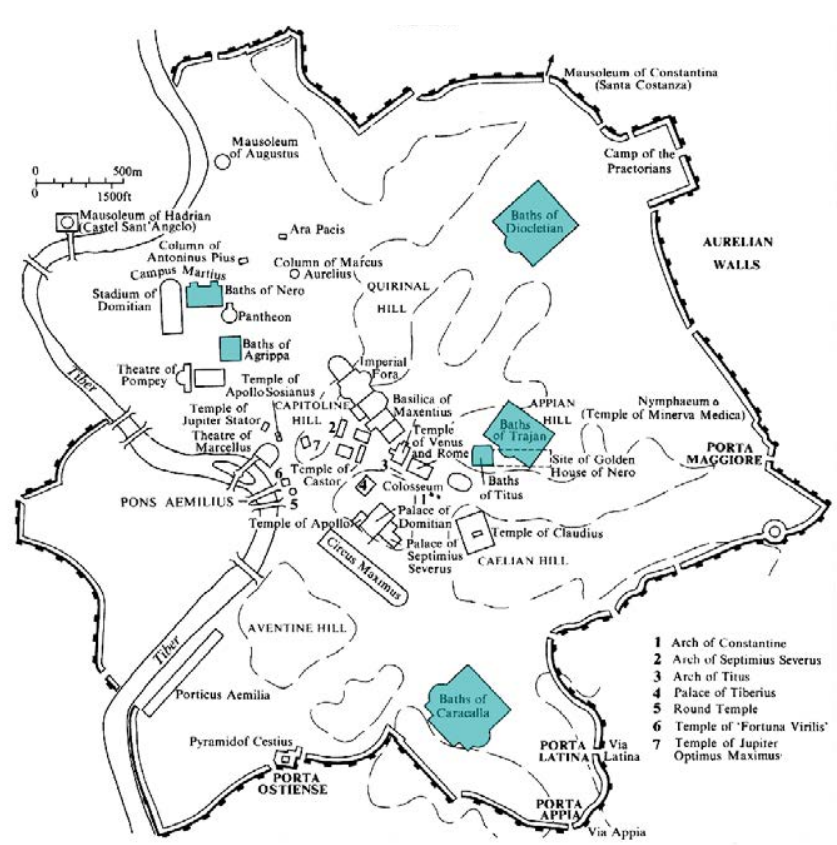

Localización de los principales baños públicos de la antigua ciudad de Roma

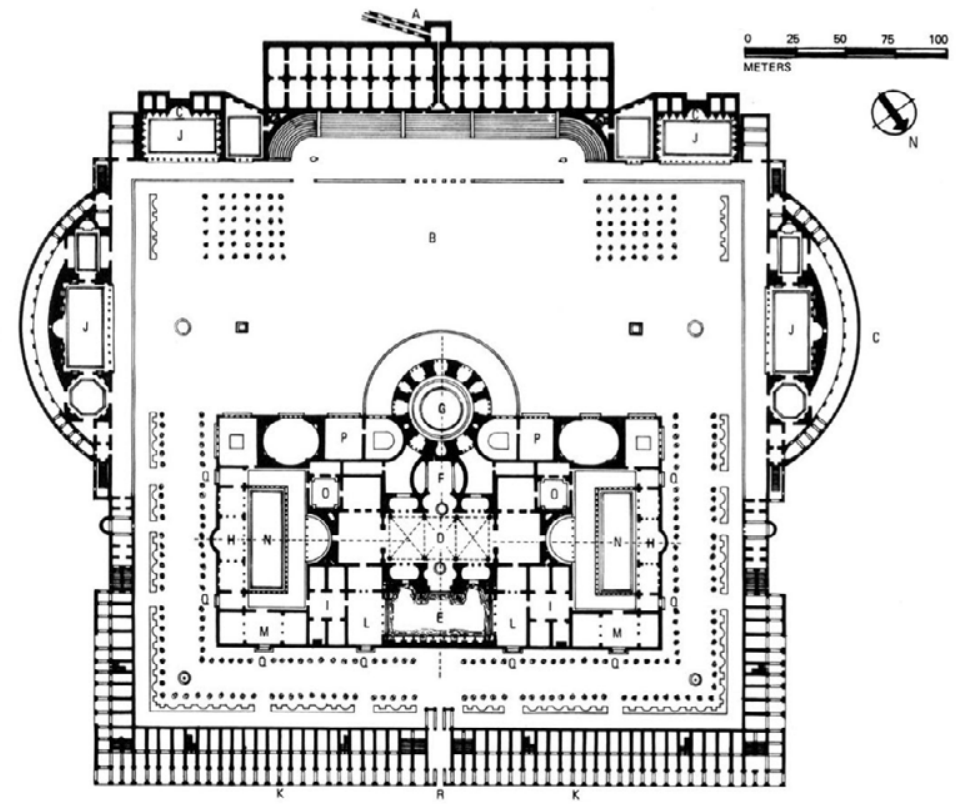

Planta baja de las Termas de Caracalla, Roma, Italia, 217-212 a.C. (A) Acueducto y cisternas, (B) campos de deporte, de exectura, (K) naños pequeños tiendasy (O) sauna, (P) habitaciones de baños, (Q) accesos, (R) acceso principa
Sin embargo, no es hasta la época romana, momento en que se produce un importante desarrollo tecnológico gracias en parte a la disposición de muchos esclavos, cuando las instalaciones del baño se popularizan a la vez que se hacen receptoras de la cada vez más prominente vida social urbana.

Al igual que en Grecia, esto no quiere decir que no exista baño en las casas romanas. Este espacio como tal no se encuentra más que en as casas de los grandes señores. De hecho el baño o balnea es uno de los elementos más característicos de estas domus romanas, en estrecha relación con la cocina. El baño parece ser más una estancia donde se realizan ostentosos rituales de limpieza corporal que un lugar de excusada misión fisiológica ${ }^{16}$. Por este motivo, el baño debe estar cerca de la lumbre; necesita por un lado de agua caliente - caldarium- y, por el otro, del conveniente confort térmico para que el ambiente sea agradable ${ }^{17}$. En ocasiones, junto a la cocina, se sitúa una letrina que aprovecha la distribución del agua a la vez que facilita la eliminación de residuos.

La cultura de la El siglo I antes de Cristo representa un periodo clave, en el que los regeneración edificios destinados al baño se multiplican por todo el imperio romano -hasta ciento setenta se llegan a contar en tiempos de Augusto en Roma-18. La sofisticación de sus instalaciones, a partir de la introducción de elementos como el vapor y el agua en una sucesión ritual de temperaturas distintas ${ }^{19}$, favorece que, desde entonces, el baño se identifique con el concepto de regeneración ${ }^{20} 21$.
16 ESPINET, Miguel. 1985. 20.

el Palatino, o en la de Fauno, en Pompeya, el balnea consiste en dos estancias adosadas y comunicadas con la cocina, en la cual se 政 otra manera, es la cocina la que actúa como distribuidor de las diferentes estancias dedicadas a la sofisticada limpieza corporal.

ro necesita, para que esta recuperación tenga lugar, un aumento de la circulación de la sangre y de la actividad de las glándulas, explicándose así la introducción

19 Después de unos ejercicios en el patio, herencia de la palestra griega, que estimulan la circulación, se pasa al tepidarium, sala con un calor moderado. Al cabo se acerca a los $100^{\circ}$. Excepto la ultima, cada una de estas salas está provista de piscinas o bañeras con agua caldeada a temperatura adecuada. Finalmente se procede a una unción de aceite acompañada de fricciones - unctio- y una zambullida en la piscina de agua fría o frigidarium (GARCÍA, Justo y DE LA PEÑA Eduardo.

saneamiento subterráneas que desembocan en los ríos cercanos (MÜLLER y VOGELL. 1989. 234-237). 

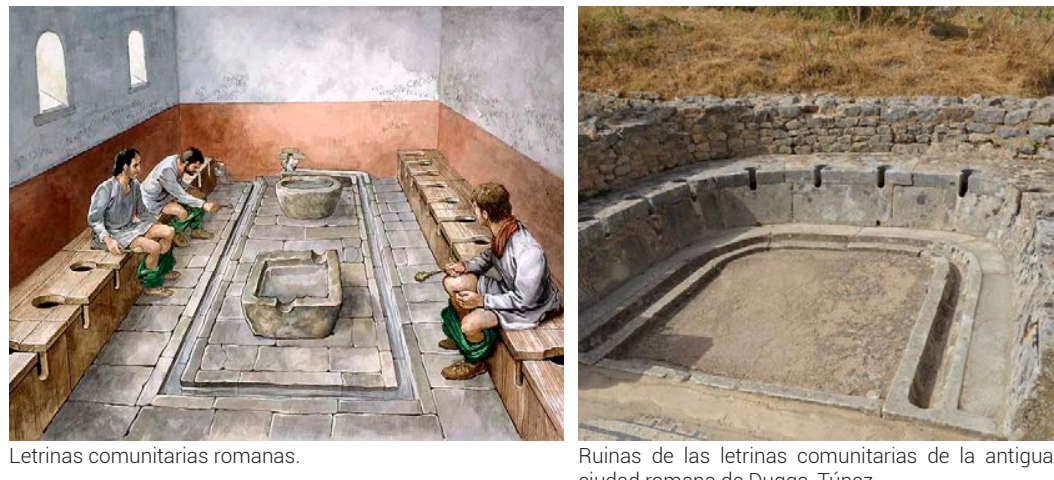
Ruinas de las letrinas comunitarias de la antigua
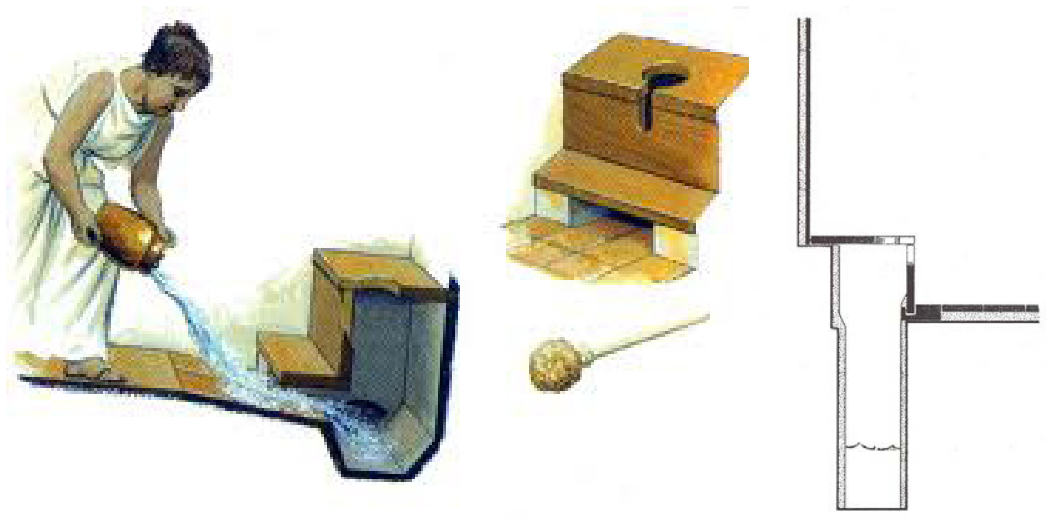

Letrina romana, (izda) funcionamiento y (dcha) sección.
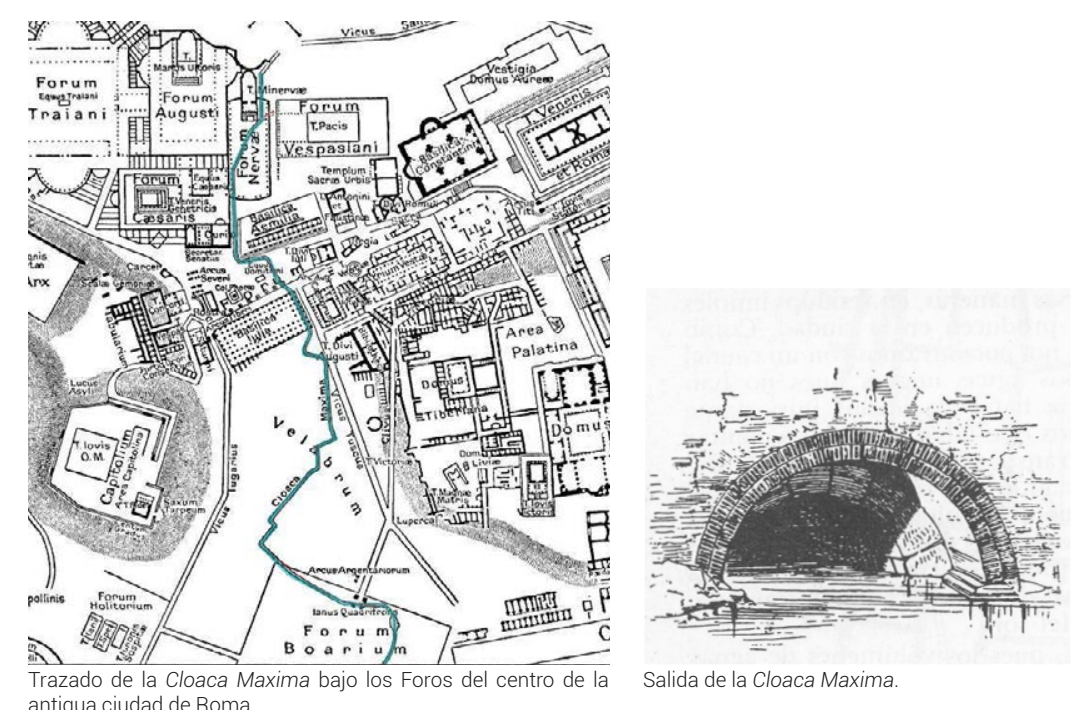

antigua ciudad de Roma.

Salida de la Cloaca Maxima.
Frente al concepto de higiene, que no aparece hasta finales del siglo XIX, a consecuencia de los descubrimientos en la ciencia médica, la regeneración es la resultante de un acto de limpieza corporal que, basado en rituales, entiende la función del agua como un elemento simbólico de purificación. Más allá de la higiene, que es un aspecto secundario, el baño romano es una forma de relajación que se realiza al menos dos veces al día: a la salida del trabajo y antes del almuerzo; da bienestar y dignifica el cuerpo, invitando al placer y al hedonismo 22 mientras, por ejemplo, se hacen negocios o se charla.

El baño romano es un deber social ${ }^{23}$ al que toda la población, separada por sexos y previo pago, tiene acceso: hombres libres, esclavos, mujeres y niños, incluidos los extranjeros ${ }^{24}$, participan de una experiencia cívica donde se diluye la enorme diversidad de la ciudad en una desnudez común²5.

Las letrinas comunitarias Junto a los baños públicos, y también dentro de otros edificios públicos de las polis, tanto en Grecia como en Roma, se encuentran las letrinas comunitarias, donde el acto de defecación es un acto público y social, compartido pero separado por sexos. Formadas por hileras de asientos perforados en una sala bien iluminada y ventilada, su posición coincide en planta con los ramales más importantes de la avanzada red de alcantarillado.

Con la caída de Roma, a finales del siglo IV después de Cristo, la población huye de la ciudad al campo por el miedo a las invasiones bárbaras, lo que provoca un decrecimiento de las antiguas civitas romanas, de las cuales muchas llegan a desaparecer por completo. Desde entonces, solo una mínima parte de la población vive con residencia fija y sedentaria ${ }^{26}$. Tanto la vida en la ciudad como la vivienda pierden, en el sentido hispanorromano, gran parte de la urbanidad.

22 El placer es el motivo principal por lo que la frecuencia de los baños tanto de los cristianos como de los filósofos no sea más que una o dos veces por mes. 23 WRIGHT, Lawrence. Op.cit. 24

4 ARESS, Philippe y DUBY, Georges. 1987/vol 1. 196 


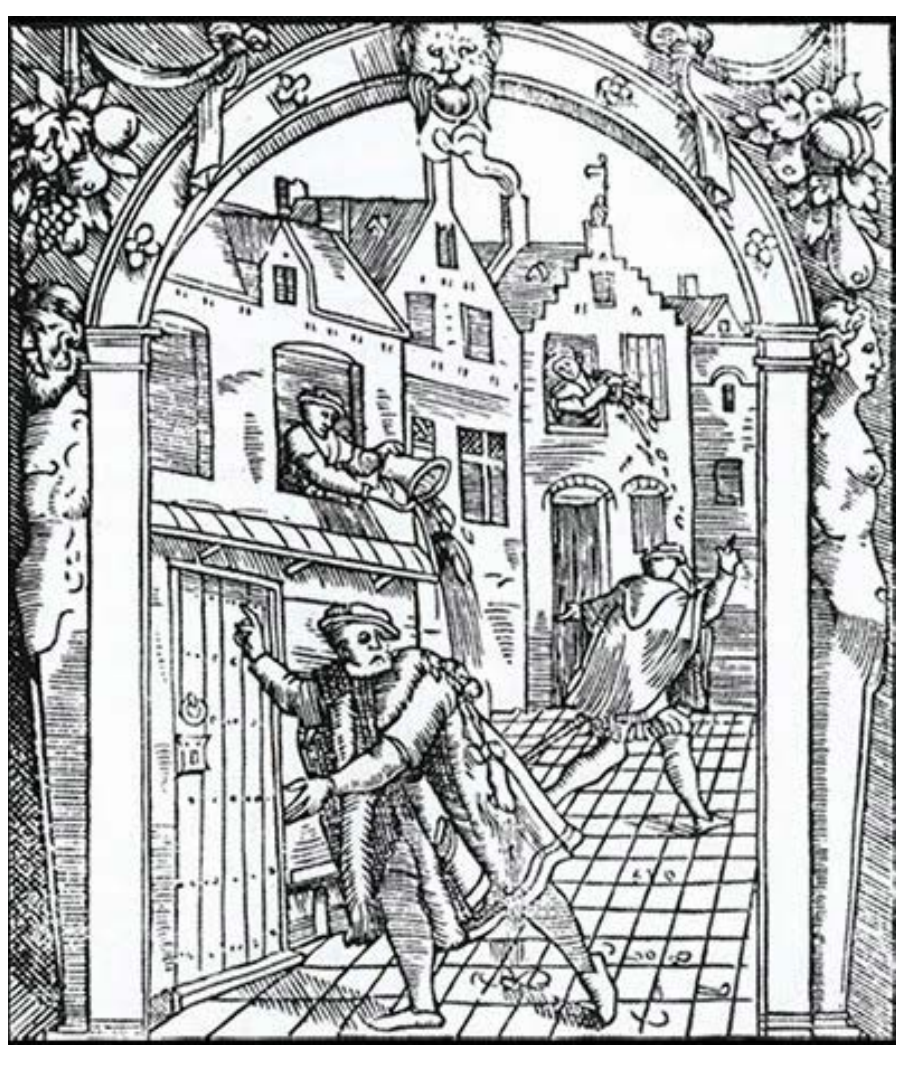

Vaciando los bacines, grabado de 'Praxis rerum criminalium' de Joose de Damhouder, los Países Bajos, 1554
A la vez que los grandes teatros, las termas, los circos y los foros desaparecen, en la vivienda se extingue un potencial social que ya no hay que formalizar, siendo víctima de una simplificación análoga a la de la ciudad. Mientras que en el período grecorromano todo núcleo poblacional participa de cierta dimensión urbana gracias a la presencia de los grandes edificios públicos, la ausencia de estos durante los primeros siglos del medievo favorece que hasta las poblaciones más importantes desarrollen en su interior un sistema de convivencia meramente rural. Esto motiva, en lo que respecta a las funciones de evacuación y limpieza corporal, que se busquen sistemas alternativos, más asequibles y acordes a esta nueva forma de vida frente al costoso establecimiento público de la Antigüedad ${ }^{27}$.

La casa urbana medieval La pobreza de la casa urbana medieval y de la vida que en ella tiene lugar es similar a la ruralidad de los núcleos de población. Como ya se ha visto en el capítulo de la cocina, la vivienda urbana de la Alta Edad Media está constituida por un solo piso de altura y se reduce a una habitación de madera hasta cierto punto privada y muy poco articulada. Esa misma habitación sirve para todos los usos: allí las gentes duermen sobre arcones, bancos o en suelo sobre camas de trapos $^{28}$ a la vez que cocinan, comen y hacen negocios.

En este contexto, y a pesar de la existencia de letrinas públicas -escasas y heredadas de la tradición romana-, las funciones de eliminación son realizadas por una gran parte de la población en el exterior, al aire libre: en un establo, un patio, un parque o un descampado.

Garde à l'eau! Por el contrario, las casas más ricas cuentan con un bacín, un elemento portátil parecido al orinal que cumple la función de letrina. Una vez que los amos los llenan con sus necesidades, con mucha frecuencia los siervos vacían tanto las heces como la orina por la ventana a la calle al grito de ¡Agua va! o Garde à l'eau! ${ }^{29}$, una práctica que se mantiene en Europa hasta bien entrado el siglo XVII, e incluso en algunas ciudades como Edimburgo hasta el siglo XVIII0 


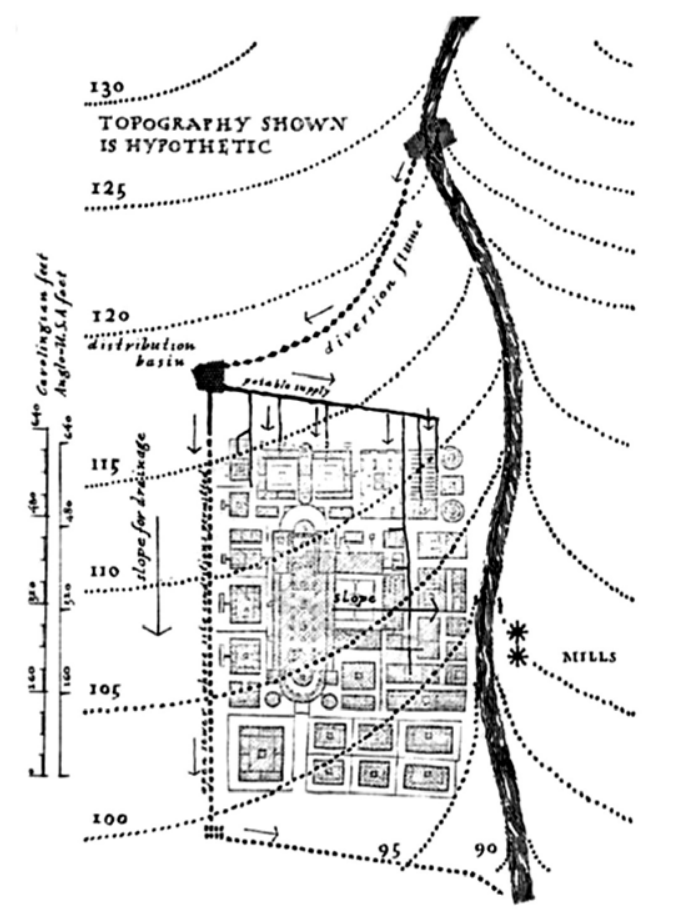

Esquema sobre el abastecimiento de agua potable y saneamiento de la

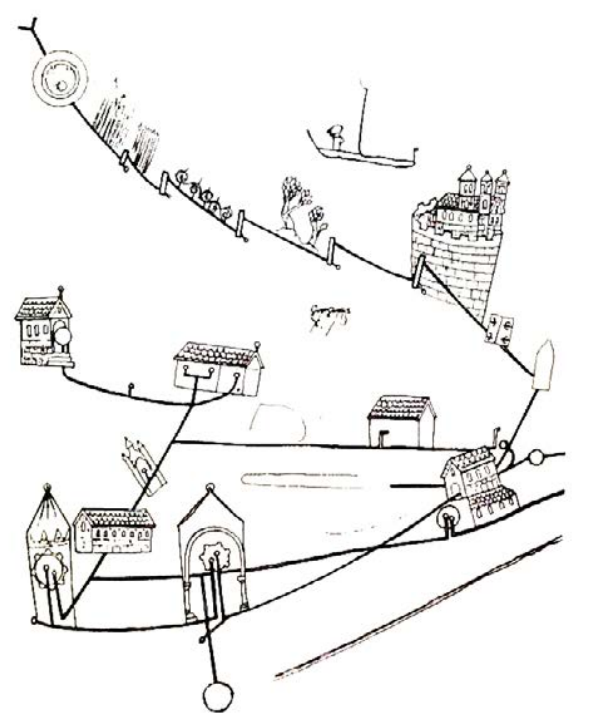

Plano del abastecimiento de aguas y del alcantarillado de la catedral del aterra, terminado en 1167
La limpieza del cuerpo también sufre un importante retroceso durante los primeros siglos de la Edad Media. La cultura de la regeneración de la Antigüedad, que no puede surgir en un clima de aislamiento ${ }^{31}$, se va desintegrando en una serie de actos que siguen caminos independientes. Mientras unos se realizan en los pocos establecimientos públicos que quedan de los tiempos romanos en la ciudad ${ }^{32}$, otros ocurren en la vivienda, donde se desarrollan unas formas caseras protohigiénicas de limpieza corporal mediante elementos portátiles como la jofaina, una bandeja o una palangana.

El ideal de la cultura de la regeneración pasa a ser un mero acto externo desvinculado del contenido ideológico inicial que lo justica. El ciudadano medieval no se lava porque esté impuro o sucio -la limpieza corporal no es todavía un valor en sí-, sino por mera costumbre social, por enfermedad o, en menor medida, por superstición ${ }^{33}$

La frecuencia de esta práctica no está, por tanto, tan asumida y organizada como en la Antigüedad, sino más bien sujeta a las posibilidades materiales de cada ciudad o a inestables modas locales.

Los centros de limpieza Parece ser que durante los primeros siglos de la Edad Media tan medievales solo las primeras comunidades conventuales continúan las antiguas costumbres regeneradoras, desprovistas de las comodidades que las caracterizan, pero con los logros técnicos intactos. Los monasterios no solo son centros de piedad, sino también de limpieza 3435. 

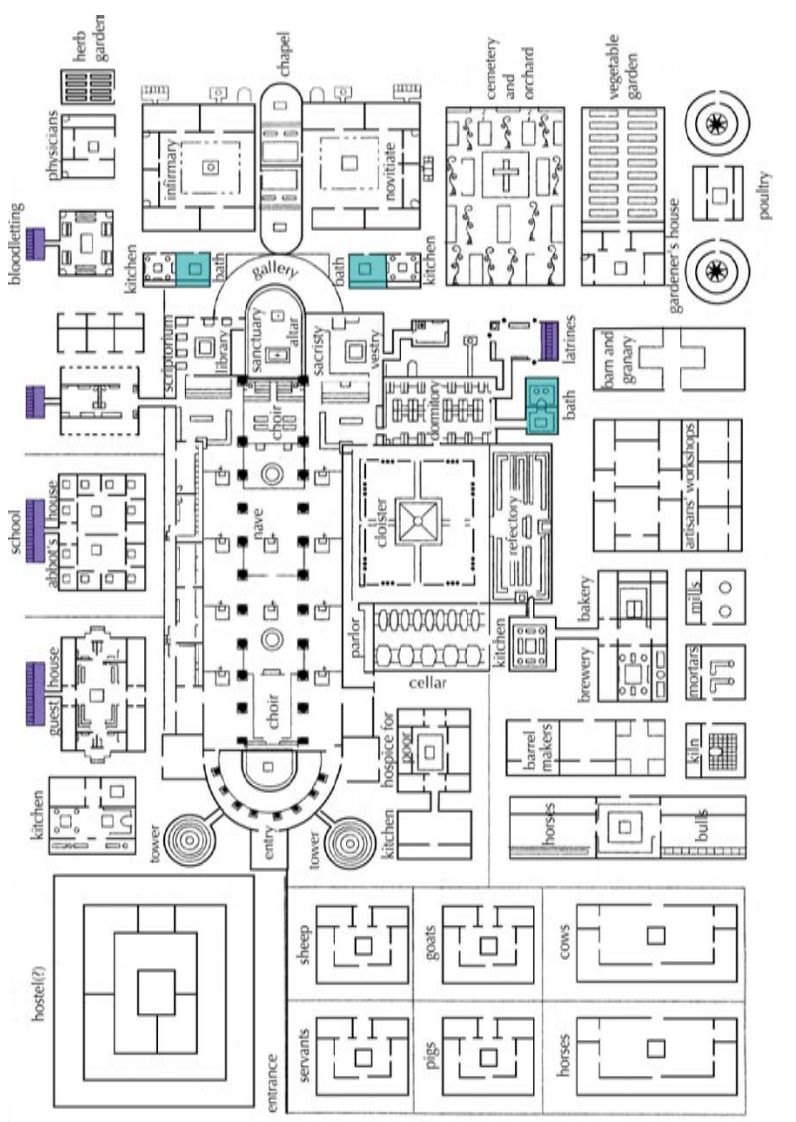

Plano esquematico de la abadía de San Galo, actual Suiza. Hacia el 820. Se observan en azul claro los baños asociados a los dormitorios y a las cocinas (abastecimiento (ver plano en pásina anterior con la hipotética red de saneamiento del complejo)
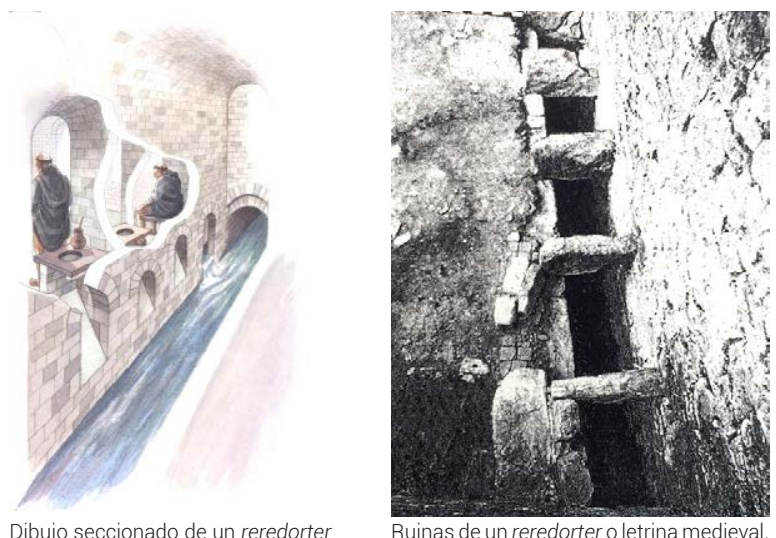

El misericord Todo monasterio incluye un lavatorium o sala de baños, con bañeras y el necessarium de madera y un sistema para calentar el agua; junto al refectorio o comedor, hay pequeños lavabos con agua fría corriente para lavarse las manos antes y después de las comidas. El misericord donde se bañan ritualmente los monjes moribundos, está junto a la enfermería, mientras que el reredorter o necessarium, el ala que contiene las letrinas ${ }^{36}$, se sitúa junto al dormitorio o dorter. Las letrinas se encuentran en el punto más bajo del edificio, en el lugar donde discurre un arroyo cuya corriente arrastra los desperdicios y los excrementos ${ }^{37}$ 38: una especie de instalaciones de conductos cubiertos que de hecho son alcantarillas subterráneas ${ }^{39}$.

A partir de la regla de San Benito ${ }^{40}$, en el siglo VI, se deja a discreción de los superiores el permitir tomar baños, y en el siglo VIII, en la misma orden, se ensaya legislar la costumbre, fijando los días de los baños conventuales. Gregorio Magno, el primer monje que llega a ser Papa, aconseja el baño dominical. Además, en el plano de monasterio de Saint Gall en Suiza, se observa un departamento para el baño, separado de otro para letrinas, situados ambos junto a la sala de monjes en la esquina del claustro. 


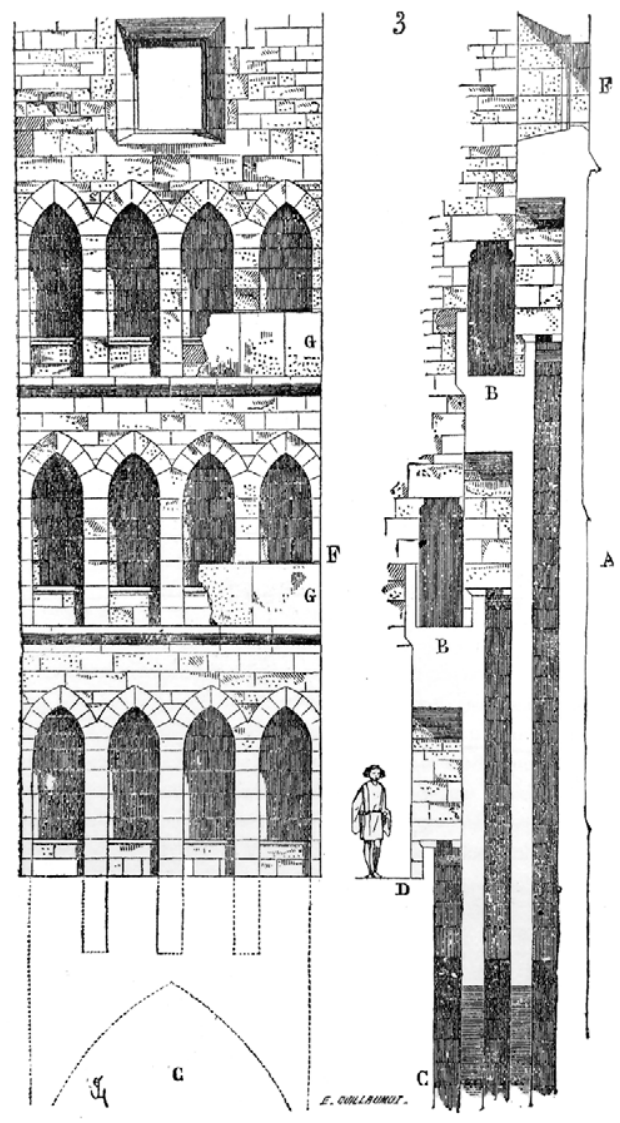
Alzado y sección de las letrinas según Violle-le-Duc del castillo de Langley,

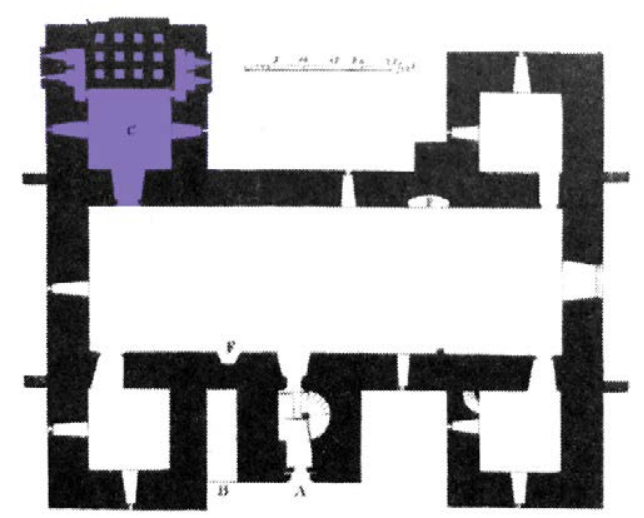

Localización de las letrinas en la planta del castillo de Langley, Inglatería, S. XIV
El garderobe medieval Junto a los monasterios, los castillos y las grandes mansiones, habitualmente desligados de la ciudad aunque inmersos en ella, también se adelantan a su tiempo en cuanto a la adecuación de los ugares más idóneos para instalar sus comunes ${ }^{41}$. Se trata de simples huecos abiertos en los muros junto a las grandes salas, generalmente cultos por tapices y paramentos, con un asiento o garderobe ${ }^{42}{ }^{43}$, de madera o piedra, sobre una especie de cañón de chimenea vertiendo las materias orgánicas directamente al exterior. En ocasiones se agrupan formando salas o torres exentas que desembocan sobre un foso o bien en un barril, con limpieza periódica, como las del castillo de Coucy, en Francia, una de las más importantes fortalezas de la Edad Media. 
La letrina volada En muchos castillos hay un garderobe para cada estancia importante, incluyendo uno situado convenientemente cerca de la sala de banquetes, generalmente ocultos por tapices y paramentos, como en la Torre de Londres. Allí se encuentra una pequeña cámara abovedada de unos 92 centímetros de ancho y una ventana estrecha. Sobre una piedra levantada y puesta de un lado a otro del habitáculo, lleva un asiento de madera con un corto tubo dirigido afuera a través de un orificio para desaguar por dentro del muro, en el foso de debajo.

Otro ejemplo parecido es el castillo de Coucy, en Francia, una de las más importantes fortalezas de la Edad Media, donde el garderobe se sitúa en una garita volada que vierte directamente sobre el foso. Cuando no se dispone de foso o riachuelo que corra por debajo para esta función, todos los conductos de bajantes terminan en un patio donde se amontonan los excrementos como ocurre en el castillo de Suffolk, en Oxford
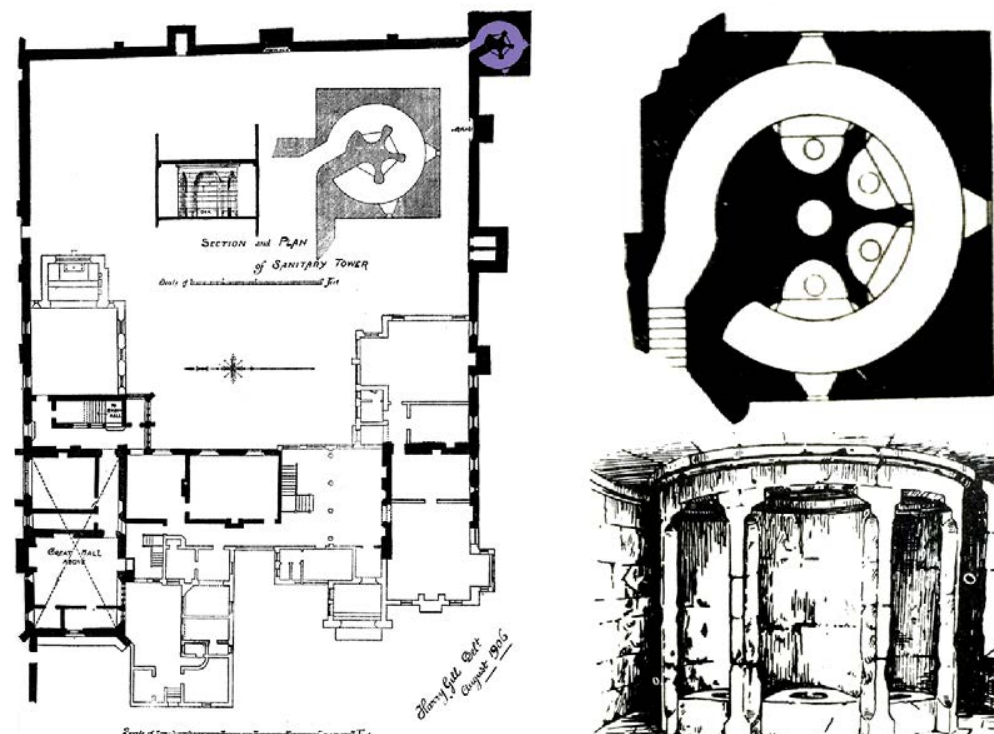

s posible que la solución espacial más radical para disponer de los retretes, sea aquella en la que las letrinas ocupan la posición más alejada de las zonas vivideras. Esto sucede en el castillo de Langley, en Northumberland -Inglaterra-, que dispone de un bloque de tres pisos con cuatro letrinas por planta con múltiples tubos agrupados pulcramente en conductos.

Un caso similar es el castillo de Southwell en Inglaterra, donde los garderobes ocupan un edificio aislado, la torre del homenaje, donde se disponen varias letrinas semi-comunales en cada planta. Colocados alrededor de un desagüe central que vierte a un foso lleno de agua, los asientos son bancos agujereados de piedra.

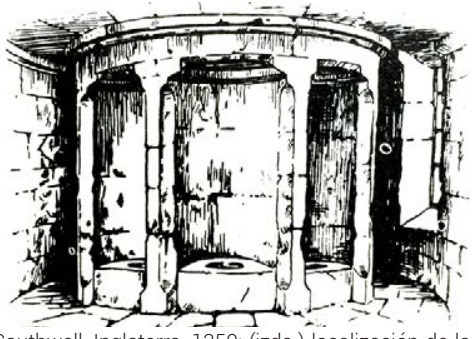

Semicomunal de cuatro letrinas comunales en el palacio de Southwell, Inglaterra, 1350: (izda.) localización de I torre sanitaria alejada del área vividera en el palacio de Southwell, (dcha.) planta detalle de la torre sanitaria imagen del interior. 

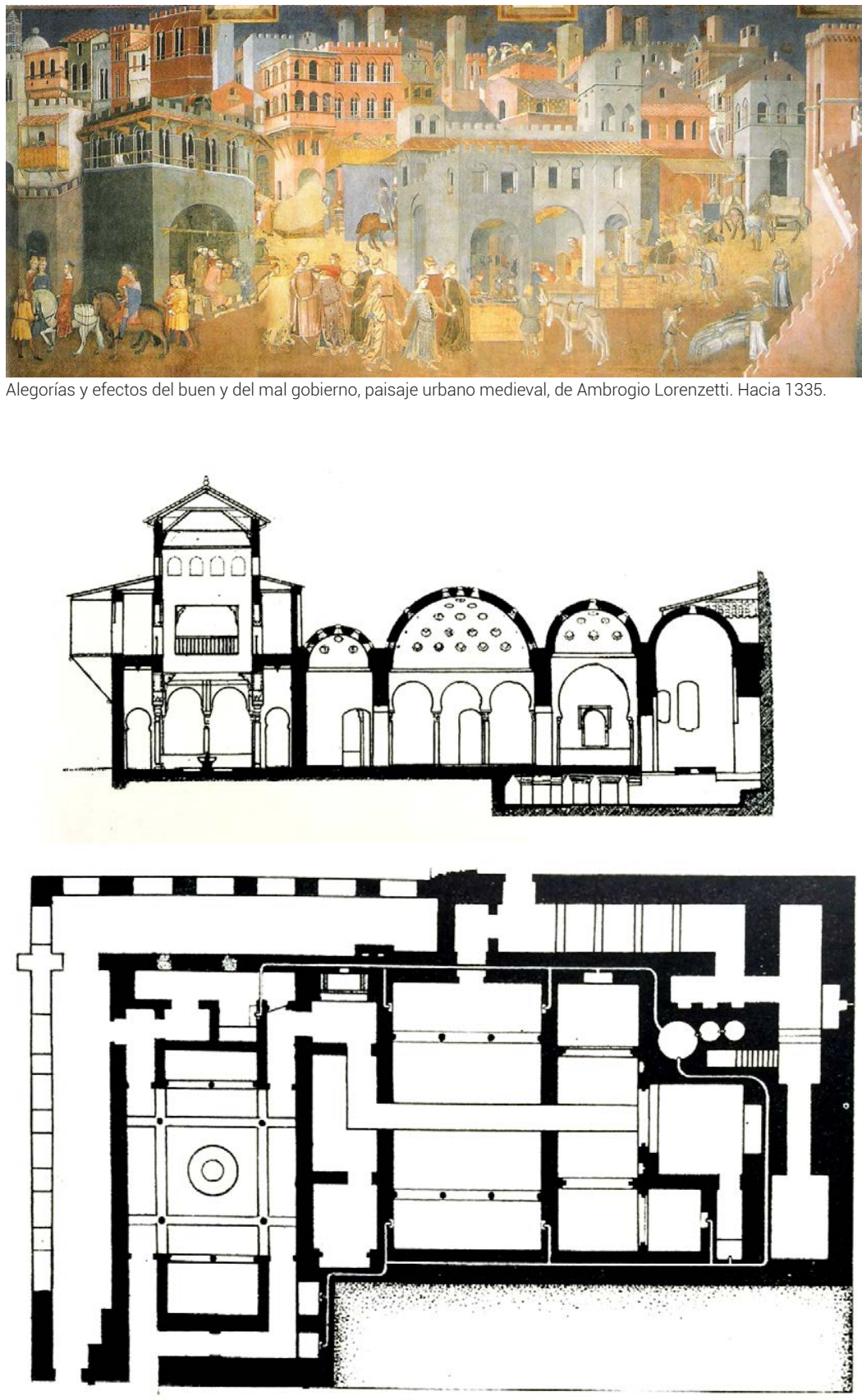

Sección longitudinal y planta de los baños del palacio de Comares. La Alhambra, Granada, España, s. XIV.
El nacimiento de la ciudad Hacia el siglo XII, la reorganización feudal agraria de la sociedad da como resultado el nacimiento de un grupo poblacional específico de tipo mercantil y artesano, la burguesía ${ }^{44}$. La práctica del comercio, el empleo cada vez más frecuente del derecho y de sus aplicaciones, termina por conseguir una alfabetización de una parte de la sociedad que es la principal responsable del desarrollo económico y de crecimiento de los núcleos urbanos ${ }^{45}{ }^{46}$. Mientras que el ciudadano antiguo es un ser político, la ciudad medieval lo convierte en un ser económico.

La recuperación del baño Desde entonces, la mayoría de las ciudades comienzan a demandar una mínima infraestructura, siendo objeto de distintas mejoras. Entre ellas destaca la construcción de una gran cantidad de baños públicos ${ }^{47}$, tanto de agua como de vapor -a través de estufas-48 a imitación, al igual que los hospitales, de la cultura islámica gracias a la vuelta de los cruzados en el siglo XII ${ }^{49}$.

El hammanmusulmán Puede ser que la construcción de los grandes hammanes musulmanes ${ }^{50}$, presentes en España desde la invasión mora en el año 711, influyeran en la recuperación y el refuerzo a partir del siglo XII de un hábito como es el del baño, que poco a poco se debilita. Sin embargo, teniendo en cuenta la sofisticación que alcanzan los baños árabes en comparación con los primitivos métodos de inmersión del medievo, todo apunta a que el baño islámico como tal es rechazado; aceptarlo significa asumir los hábitos de los musulmanes y, por tanto, su sometimiento ${ }^{51}$ 52. Paradójicamente, durante esta época, otros aspectos de la cultura musulmana son absorbidos por la cultura cristina, produciéndose una sociedad mucho más avanzada en todos los sentidos. Esta situación pone de manifiesto cómo la ideología respecto al cuerpo, tanto como la tecnología disponible, juegan un papel fundamental en la definición de la cultura de la regeneración y por tanto, de la limpieza del cuerpo. 

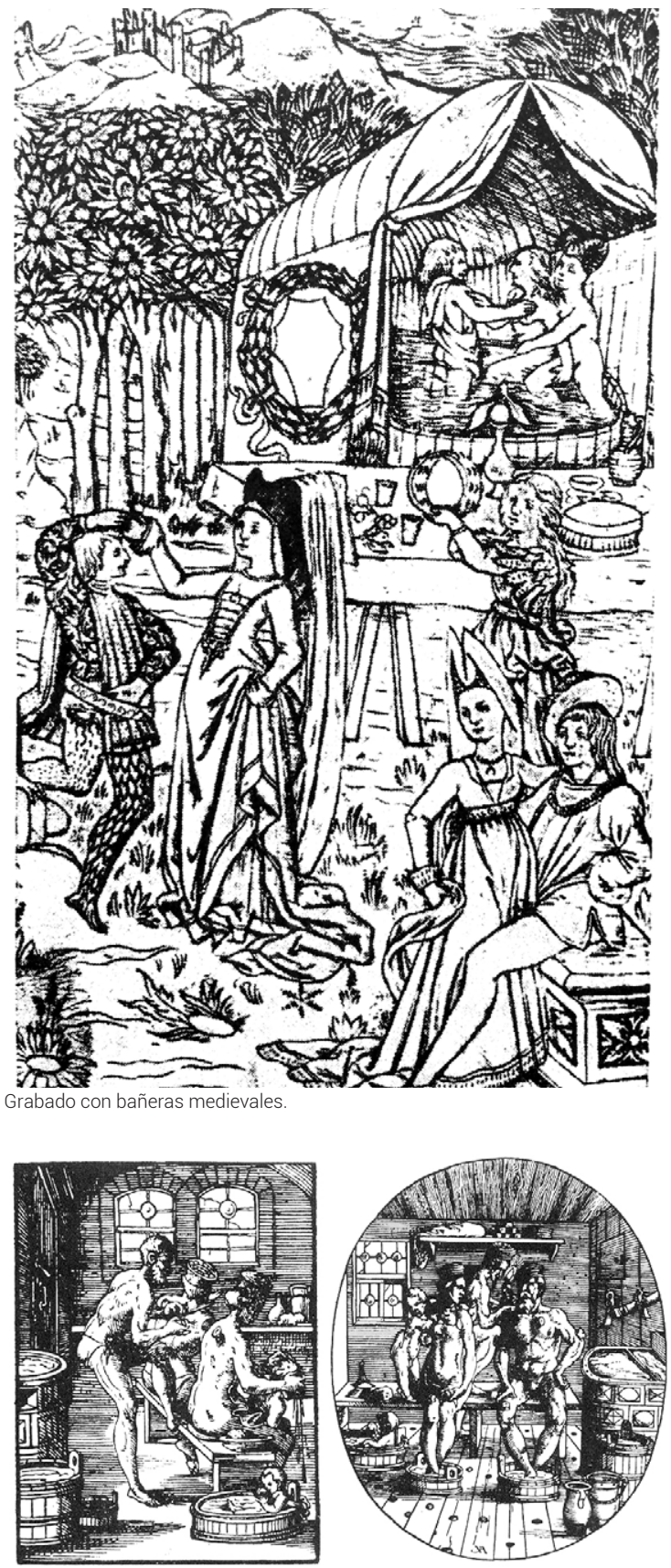

El baño público medieval En cualquier caso, a partir del siglo XII la práctica del baño público regresa a las ciudades después de muchos siglos de ausencia generalizándose entre la población; mientras, los baños privados se reservan exclusivamente a los monasterios, a las viviendas importantes, a los castillos y a los grandes palacios.

Las grandes bañeras Tanto en la ciudad como en la vivienda, el lavado del cuerpo se comunitaria realiza bien en el agua del baño o bien al vapor de la estufa -stew- ${ }^{53}$ 54 . Los grabados medievales muestran con frecuencia que el baño de inmersión tiene lugar en grandes bañeras portátiles, generalmente de madera, aunque a veces son de cobre o de plata ${ }^{55}$, de planta redonda u ovalada, con una capacidad aproximada de 135 litros de agua, y un diámetro cercano a un metro, aunque a veces puede llegar hasta los tres metros, donde se alcanza una intimidad muchas veces compartida.

Antes del siglo XIV, la exhibición del cuerpo desnudo es algo natural. La falta de pudor y vergüenza es una constante durante los primeros siglos de la Edad Media, lo que se refuerza a través de la práctica del baño, entendido, al igual que en la Antigüedad y en el Islam, como un lugar de relación social ${ }^{56}$. Es frecuente la presencia de grupos de personas del mismo o distinto sexo compartiendo bañera a la vez que hablan, comen, beben y escuchan música ${ }^{57}{ }^{58}$. En otras palabras, el baño medieval es una mezcla de sexos, edades y desnudeces que parecen fundirse en una misma tina de agua y vapor mientras comensales y criados circulan a su alrededor ${ }^{59}$. En muchas ocasiones el baño se combina con otras actividades como el corte de pelo, el afeitado de la barba o la práctica de la medicina a través de la aplicación de ventosas, la sangría y la ejecución de operaciones menores realizadas todas ellas por los cirujanos-barberos, también conocidos como los caballeros de la orden del baño60.
53. ARIES, Philippe y DUBY, Georges. Op.cit/vol 4.290. 54 En las ricas mansiones burguesas de finales de la
Philippe y DUBY Georges 1987 (vol 4 . 290). ${ }_{55}$ GARCIA, Justo y DE LA PENA, Eduardo. Op.cit. 67. ${ }_{56}$ G GIEDION, Siegfried. OP.cit. 657 . ${ }_{58}^{5}$ En las casas ricas, la familia entera y sus invitados se bañan mientras el agua está caliente. 59 En las casas ricas, la familia
60 WRARELLO, Georges. 1991.45. 

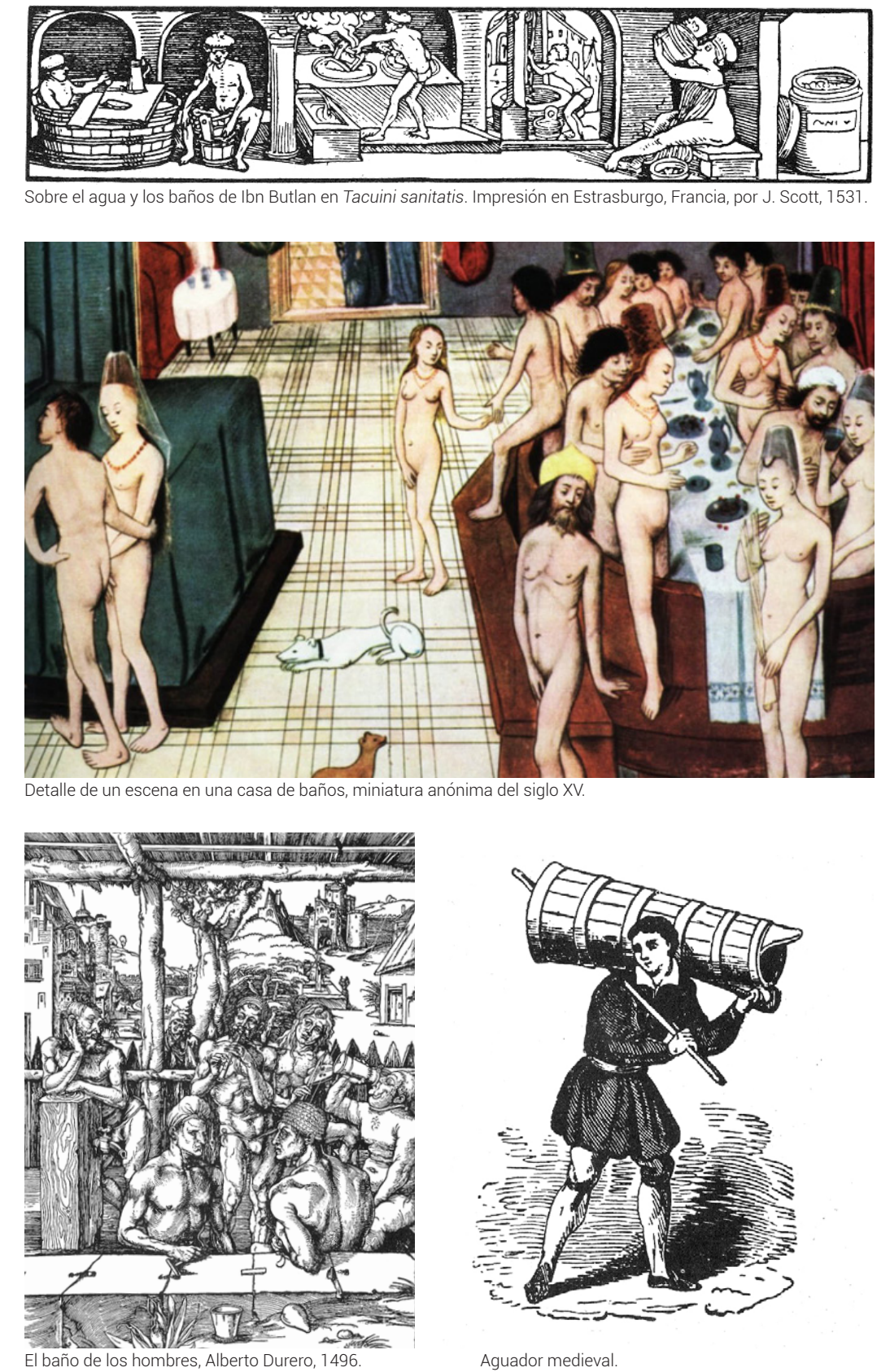

Aguador medieval.
El placer y el juego En cualquier caso, y a pesar de las distintas actividades que en él concurren, la finalidad última de los baños y las estufas públicas medievales es el placer y el juego. Si el agua en un principio juega un papel simbólico-purificador en las sociedades cristianas a través de prácticas como por ejemplo el bautismo, en la Edad Media, sobre todo en los baños públicos, se presenta como un medio ideal para erotizar, en el que se sienten emociones físicas ${ }^{61}$.

Las miniaturas medievales muestran con frecuencia las bañeras en los escenarios más variopintos, interiores o exteriores, como dormitorios, grandes salones o en medio del campo ${ }^{62}$, pero también muchas veces forman parte de celebraciones como bodas y banquetes $^{63}$. No tienen una ubicación determinada en el espacio. El agua se calienta aparte y se transporta hasta la bañera, que después hay que vaciar manualmente. Para ello existen pequeños achicadores de madera que son como bañeras en miniatura, con una sola asa, aunque en algunos grabados también constan de tuberías de desagüe. No es hasta la popularización de la chimenea doméstica, en el siglo XV, cuando estas bañeras adquieren una posición fija dentro de la vivienda, generalmente cerca de la cocina, junto al fuego, lo que facilita no solo el calentamiento del agua, sino también su transporte hasta la tina ${ }^{64}$. 


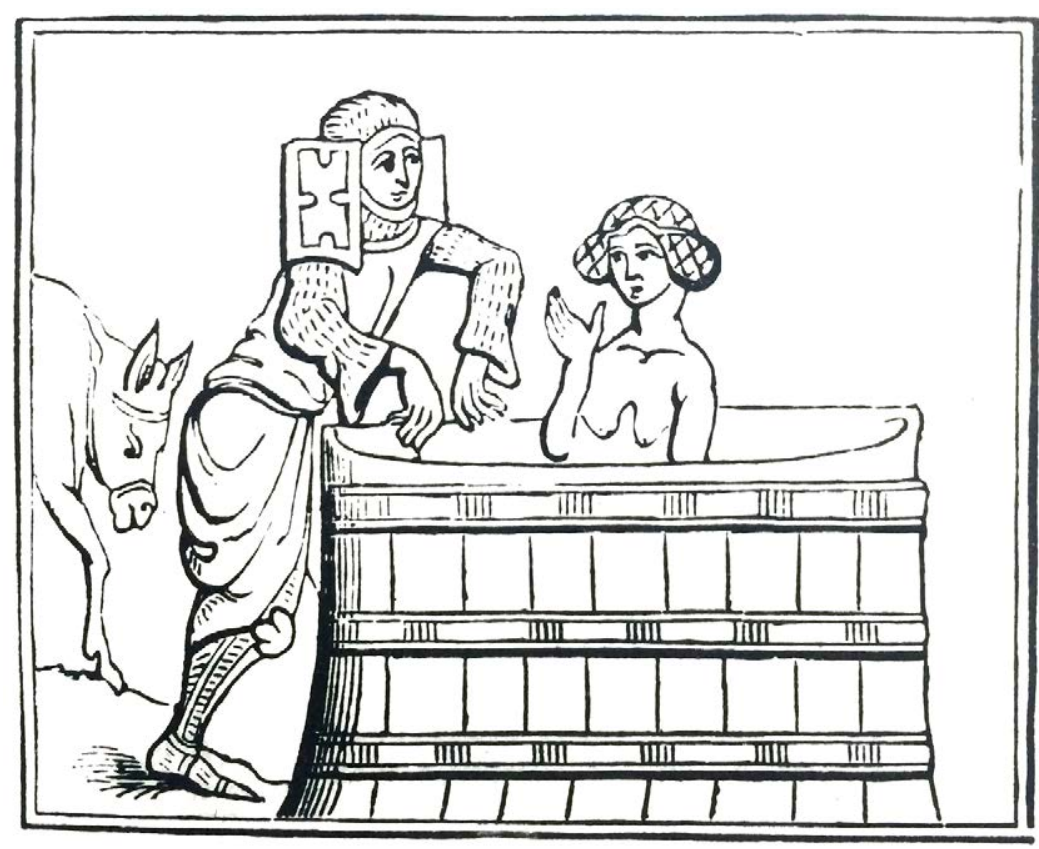

Grabado en un manuscrito donde una dama ofrece el baño a un caballero, s. XIII
Los tratados de cortesía de Entre los nuevos modelos culturales surgidos durante la Edad Media la Edad Media destaca el de la cortesía ${ }^{65}$, un acontecimiento esencial en el proceso de la civilización, rasgo que desde entonces distingue a Europa ${ }^{66}$. Por primera vez se elabora y aplica de forma general un código de buenas costumbres que, a través de la literatura, de los libros de consejos y los manuales de courtoisie, y desde la educación infantilib regulan conductas cotidianas tan diversas como los modales en la mesa, la vestimenta o el comportamiento ante otras personas ${ }^{68}$. Estas reglas además de establecer un código de buenas costumbres, buscan la diferenciación de las clases altas de los grupos inferiores de la sociedad campesina 6970

Es el primer ideal de un civismo que, unido a la urbanidad (las buenas costumbres formadas en la urbe), constituyen hasta el día de hoy para los europeos un código de valores sociales y de comportamientos distinguidos

Curiosamente, estos libros de etiqueta no hacen referencia a la práctica del baño, aunque sí parece de buena educación ofrecérselo a los visitantes recién llegados ${ }^{71}$. En cualquier caso, esta ausencia de normas coincide con la imprecisión acerca de su frecuencia. Los pueblos del norte, que poseen grandes bosques, por ejemplo tienen la costumbre de bañarse todos los sábados por la noche ${ }^{72}$, bien en el patio o bien en la cocina, junto al fuego ${ }^{73}$. Los más creyentes pueden bañarse incluso tres o cuatro veces al dia ${ }^{74}$, lo que conduce a relacionar el ritual del baño con las prácticas de la confesión ${ }^{75}$ y e papel purificador del agua. Los reyes se dan un baño, en el mejor de os casos, una vez al mes, y es probable que sus súbditos lo tomaran aun con menos frecuencia ${ }^{76}$

65 La cortesía deriva su nombre, sin duda, de la corte y la vida cortesana. Las cortes de los grandes señores son como escenarios en los que cada uno trata de labrar su fortuna. Esto no puede conseguirse más que alcanzando el favor del principe y de los nobles más importantes en la corte, por lo que hay que esforzarse todo lo posible por hacerse bienquisto. Lo mejor para ello es hacer creer al otro que se está dispuesto a servirle en todo momento y con todas las fuerzas, aunque muchas veces no tengamos tal inclinacion ono queramos por muy buenas razones. Para esto esta la cortesia, que nos hace refiejar tal determinacion en nuestra nosotros por el cual se siente inclinado a concedernos sus favores. Este es el resultado más habitual del ejercicio de la cortesía lo que concede una gran ventaja a quien la práctica Citado en ELIAS, Norbert. 1987. 62.

66 LE GOFF, Jacques. 1995. 30 .

${ }_{67}$ Aunque es ya del siglo XVI, este es el caso del tratado de buenas maneras de 1537 De Civilitate Morum Puerilium (De la urbanidad en la manera de los niños), de Erasmo de Rotterdam

6a. a su alrededor los comportamientos refinados de la corte (LE GOFF, Jacarse
rascarse la cabeza ostensiblemente (VIGARELLO, Georges. Op cit 14)

69 ELIAS, Norbert. Op.cit. 132

70 La psicogénesis del proceso civilizatorio implica para Elias el análisis de procesos de largo plazo de las conductas cotidianas particulares, como la compostura tarde no lo son debido al paulatino avance de los "umbrales de la vergüenza" como parte de ese proceso civilizatorio.

71. WRIGHT, Lawrence. Op.cit. 67 .

${ }_{73}$ GIEDION, Siegfried. OP.cit. 65

74 ARIES, Philippe y DUBY, Georges. 1987/vol 4. 294

75 ARIES, Philippe y DUBY, Geor 

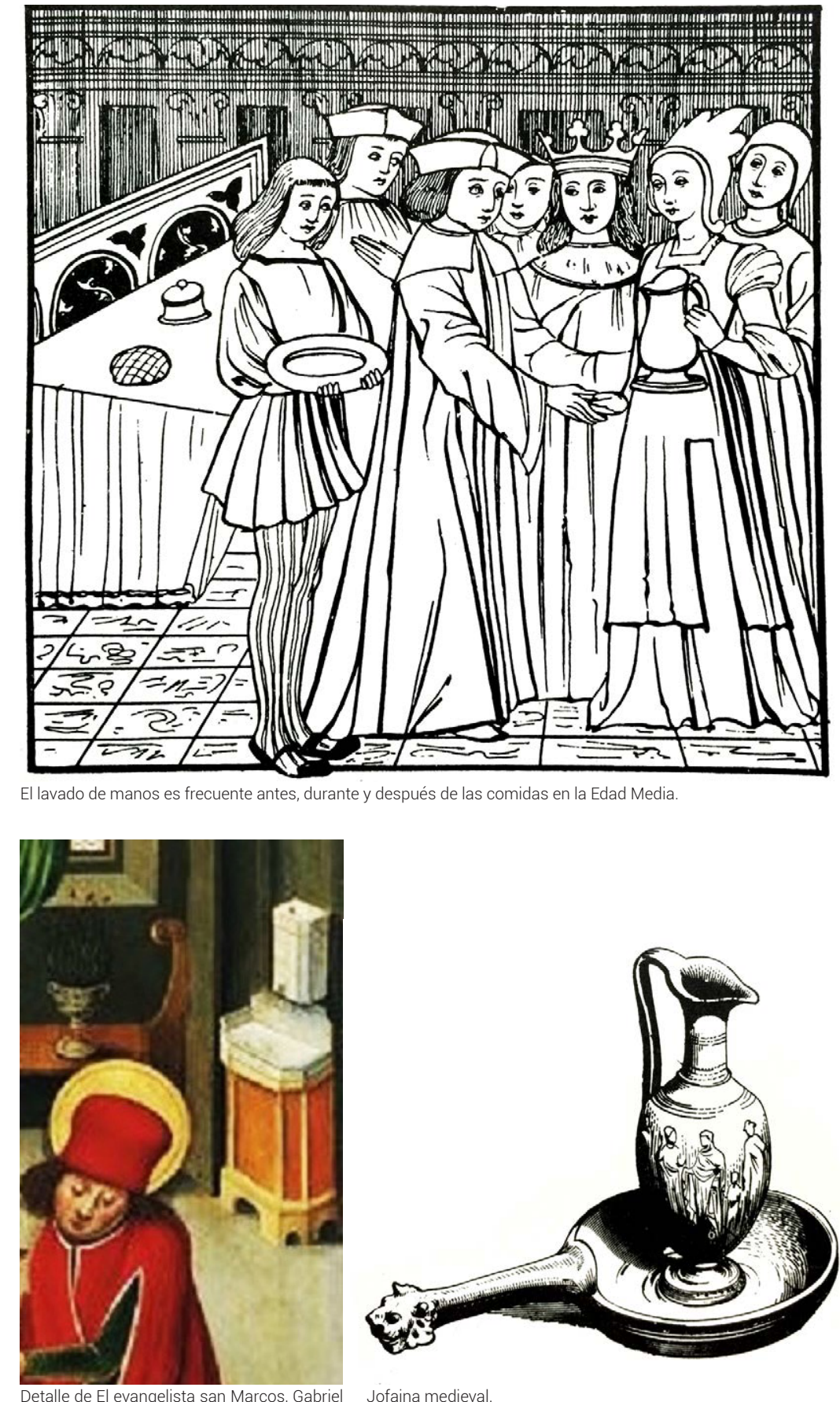

Mälesskircher, 1478

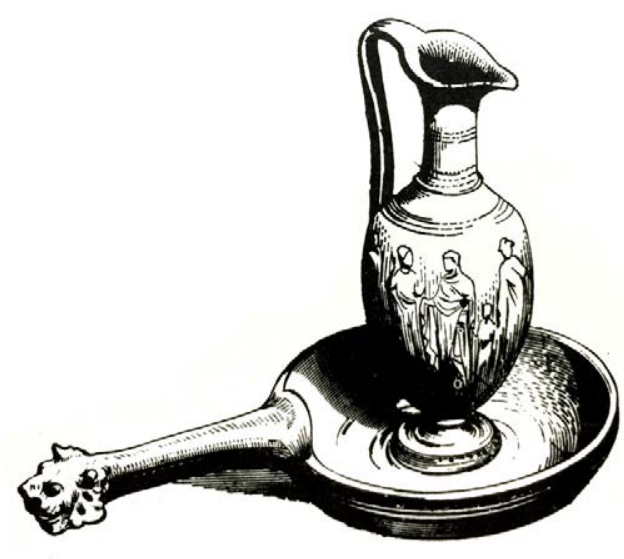

Jofaina medieval.
El aguamanil Al contrario que el baño de inmersión, los libros medievales referentes a la etiqueta insisten en el lavado de manos, cara y dientes todas las mañanas ${ }^{77}$, unas prácticas que han llegado hasta nuestros días. Estas nuevas reglas de limpieza parcial tienen lugar en el espacio doméstico gracias a elementos portátiles ya presentes en la Antigüedad, como, por ejemplo, el aguamanil, un conjunto de jofaina y jarra. Se trata de prácticas deslocalizadas que no exigen de una estancia especializada, por lo que su contexto sigue siendo la habitación multifuncional, y que en el caso de las viviendas más ricas son ofrecidas por el servicio doméstico, que vierten el agua del jarro mientras se mantienen las manos sobre la jofaina. Después se ofrece una toalla de lino. El agua puede estar perfumada o cubierta de pétalos de rosa, pero el jabón, fabricado por primera vez en Inglaterra en el siglo XIV, no se trae a la mesa $^{78}$

La fuente fija En las habitaciones multifuncionales de las viviendas más ricas el sencillo aguamanil se sustituye por formas fijas de fuentecillas o lavabos. Se trata de una pila fija adosada a la pared junto a un depósito de agua, metálico o de piedra, con mayor capacidad que un simple jarro y con un grifo y una toalla al lado que parece suprimir la necesidad de sirvientes ${ }^{79}$. En cualquier caso, parece que este tipo de lavabo no es muy común, ya que en los sucesivos siglos las transformaciones de este elemento parecen partir del popular y accesible aguamanil.

Las abluciones parciales adquieren mucha importancia en el contexto de la mesa, donde la etiqueta y los modales se toman en serio. El lavarse las manos antes, durante y después de la comida, es necesario ya que aunque utilizan cucharas para la sopa, no hay tenedores, y la gente come en buena medida con los dedos ${ }^{80}$ 


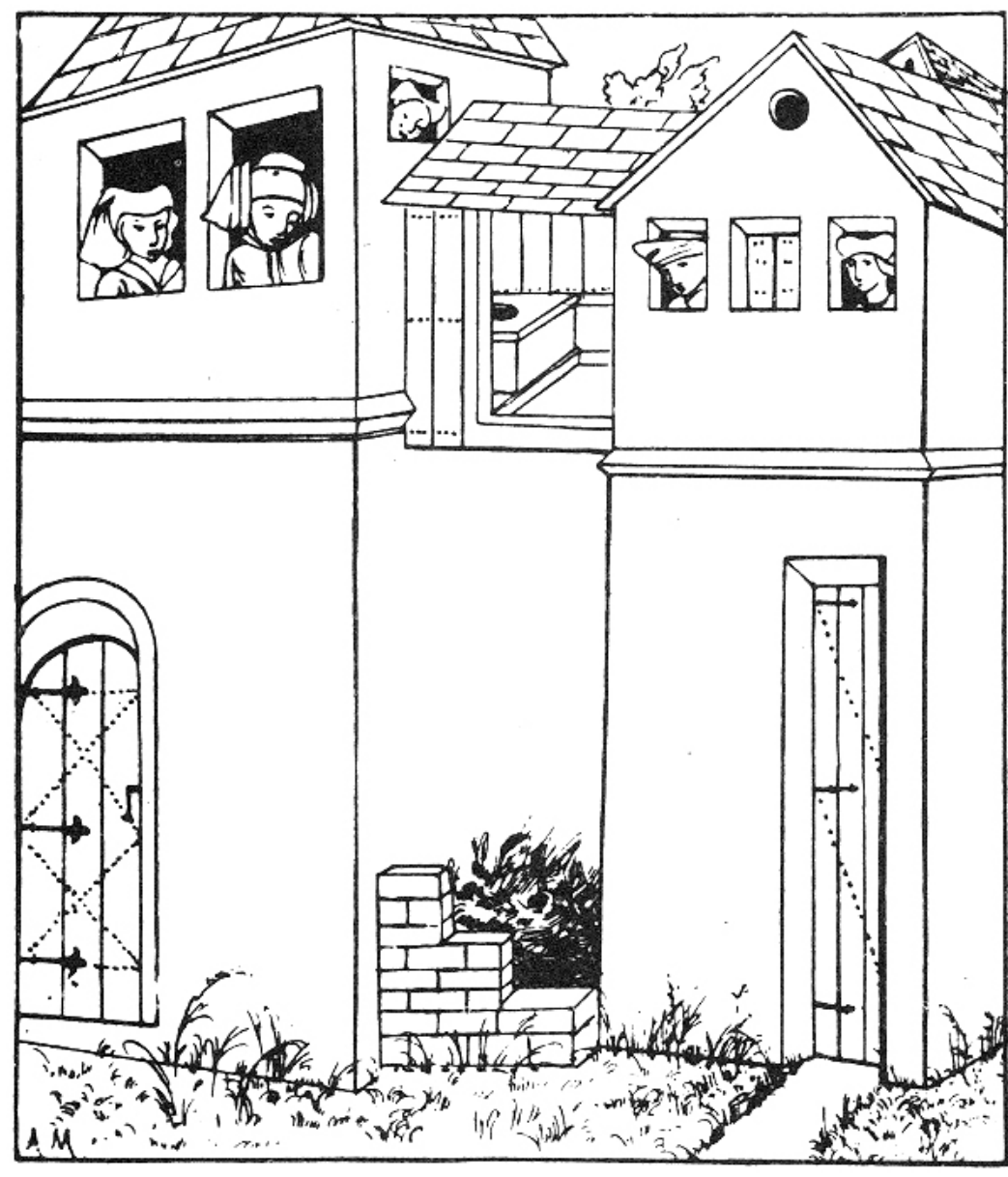

Letrina en vivienda acomodada, s. XV.
Las letrinas domésticas En la psicogénesis del proceso civilizatorio, junto a las prácticas de ablución parcial las actitudes vinculadas a la realización de las necesidades fisiológicas también son objeto de regulación en los nuevos manuales de cortesía. De esta manera, y a partir del siglo XII, comienzan a instalarse en las viviendas privadas más ricas letrinas particulares, un modelo que ya existe en las grandes mansiones, castillos y monasterios medievales.

Estas letrinas, semejantes a las cámaras privadas de los castillos, son modestas garitas de madera con un simple banco agujereado, voladas sobre un patio o un espacio vallado que funciona como estercolero. Sin embargo, y a medida que avanza la Edad Media y la ciudad se colmata de edificaciones, las mismas garitas que antes vuelan sobre solares vacíos vierten desde entonces sobre las vías públicas. En los casos en los que discurre una especie de acequia de caudal muy lento bordeando la ciudad, esta se aprovecha para verter ahí las materias orgánicas, recibiendo el nombre de merderon, merderet o merderau ${ }^{81}$. Todas ellas apelaciones derivadas de la palabra mierda, como se aprecia.

En las casas urbanas más modestas, la construcción de letrinas y su adecentamiento es una batalla habitual entre los particulares y la autoridad, que desde el siglo XII intentan, sin éxito, a través de las primeras ordenanzas, regular su número, situación y lugar de desagüe ${ }^{82}$. En estos casos la letrina es un descuidado cubículo que vierte a un pozo ciego cavado en el patinejo y que, con bastante frecuencia, es blanco de quejas por parte de los vecinos debido a su mala conservación.

En todos los casos, ya se trate de barrios céntricos o periféricos, ricos - pobres, durante esta época la urbanidad no sobrepasa los límites de cada vivienda, y la infraestructura necesaria en concentraciones demográficas de esa escala, con la que sí cuentan las ciudades de la Antigüedad, brilla por su ausencia ${ }^{83}$. 


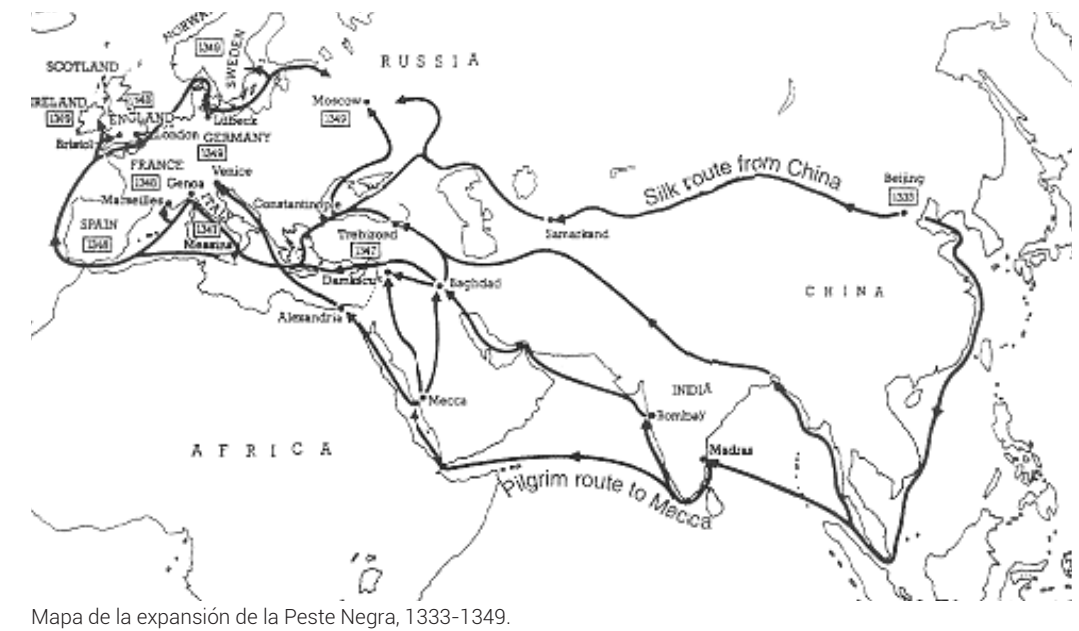

Mapa de la expansión de la Peste Negra, 1333-1349
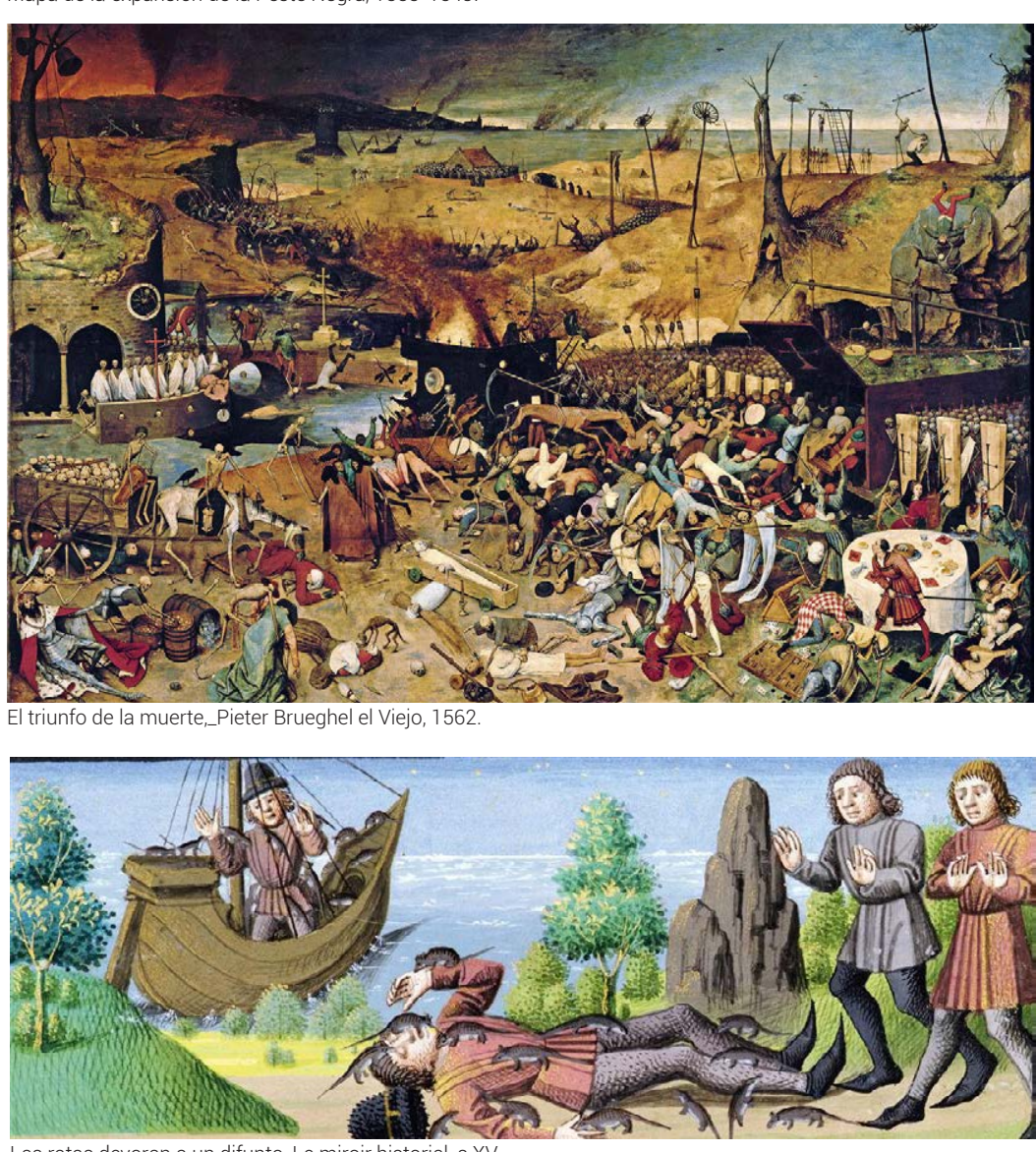

Las ratas devoran a un difunto, Le miroir historial s.XV -
El orignal El orinal o bacín, generalmente de cristal o de loza, continúa siendo el medio doméstico más corriente y popular para la evacuación durante este período, gracias a su comodidad de uso y a la posibilidad que ofrece de hacer el examen médico ante una posible enfermedad. La gestión de su limpieza se realiza a través de los pozos y patios mientras es posible, y la vía pública, a cualquier hora y no siempre previo aviso, cuando no hay más remedio ${ }^{84}$

La aparición peste negra Entre los acontecimientos de finales de la Edad Media, la aparición de la peste negra en 1346 es el que más transforma la vida de la sociedad tal y como se conoce. Procedente de Asia, esta enfermedad que acaba con un tercio de la población europea, afectando sobre todo a la fracción más desnutrida ${ }^{85}$, es identificada pero no explicada.

Mientras unos creen que el contagio se produce a través de la mirada, el aliento o la tos, las autoridades señalan que la plaga se extiende por la basura de las calles. La ignorancia acerca del origen de la peste durante esta época es total. No es hasta mediados del siglo XIX, a partir del descubrimiento de la teoría microbiana de Pasteur, cuando las causas biológicas de la plaga y la complejidad de su transmisión a través de la propagación de los roedores y de las pulgas portadoras de la enfermedad son descifradas 8687.

34 En las crónicas de la época se leen multitud de quejas y lamentos hacia esta práctica. Muy significativo es el ejemplo del cronista del primer viaje de Carlos V a España que dice cuando habla de Valladolid. No es or de Guinea lo que cae sobre la cabeza. Y si el paciente se quejaba, recibía otra rociada de insultos de vecino, muy extrañado de tanta pulcritud. (LAMPEREZ, Vicente. Op. cit. II. 32).

85 El crecimiento demografico que experimenta el mundo feudal en plena Edad Media empobrece los cultivos y reduce el suministro de alimentos a la población Consecuentemente, el sistema in
${ }_{86}$ DE LANDA, Manuel. 2012. 157 .

. pulgas que se alimentan de la sangre de las ratas infectadas y que luego muerden a los humanos produciendo los famosos bubones. Los brotes de peste negra continuaron hasta el siglo XVIII (DELANDA, Manuel. Op. cit.156). 


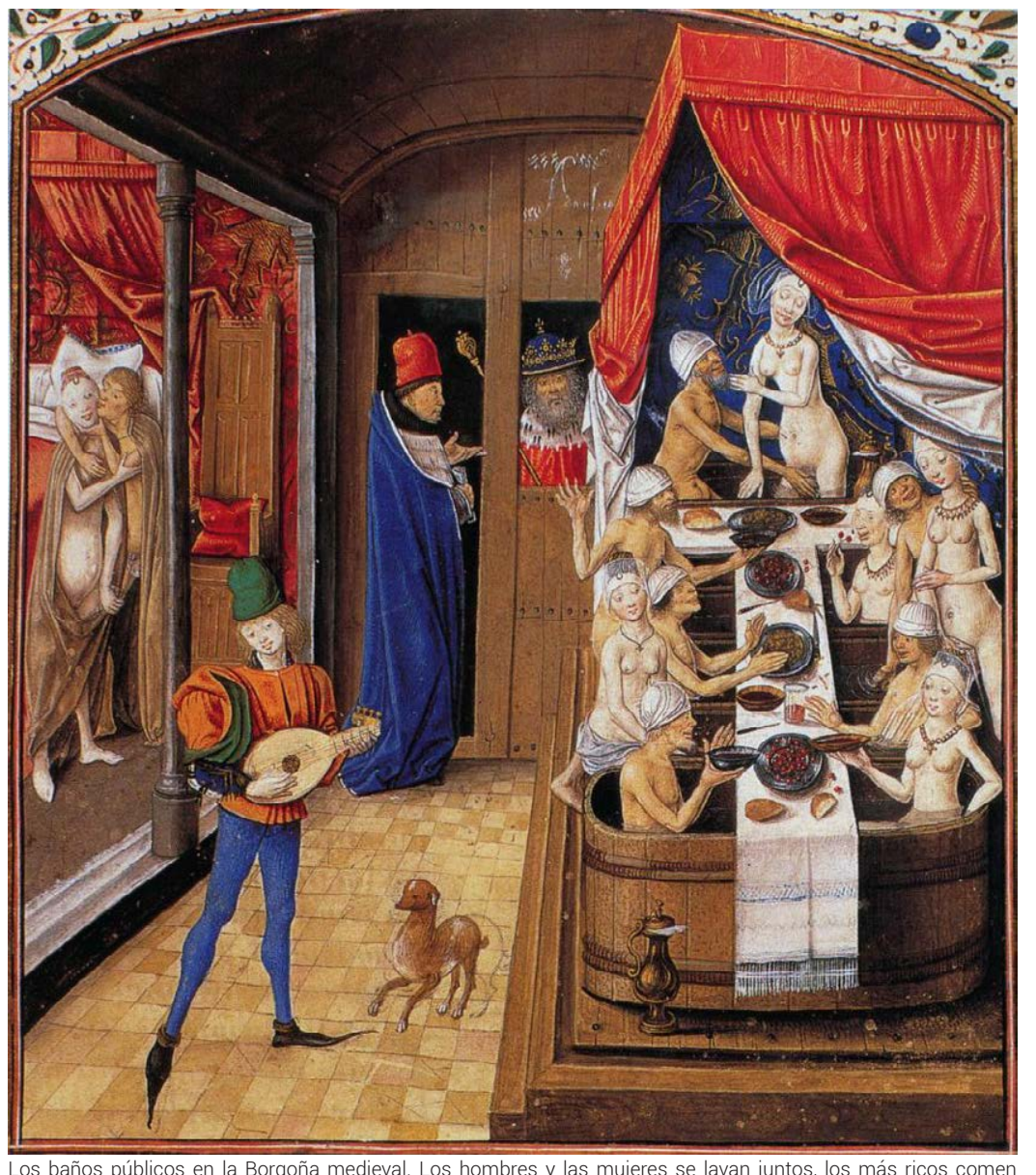

mientras se baña.
El baño público convertido Ante esta situación de profundo desconocimiento y desconcierto, en burdel que la iglesia justifica con la llegada del Juicio Final por los pecados cometidos, la población adopta dos posturas vitales radicalmente opuestas; por un lado, los que se martirizan y rezan pidiendo piedad por otro, aquellos que deciden hacer caso omiso a la iglesia y disfrutar al máximo de lo que les queda de vida. Los últimos comen, beben y fornican sin parar, y lo hacen en los baños públicos, muchos de los cuales acaban convertidos en burdeles, siendo objeto de regulación y de una vigilancia constante.

La incapacidad de la Iglesia para explicar el mal de la peste provoca una pérdida de credibilidad de la institución y fomenta la búsqueda de otro tipo de explicaciones más 'científicas' capaces de justificar el origen y la causa de las muertes. Es el principio del fin de la práctica del baño de inmersión. 


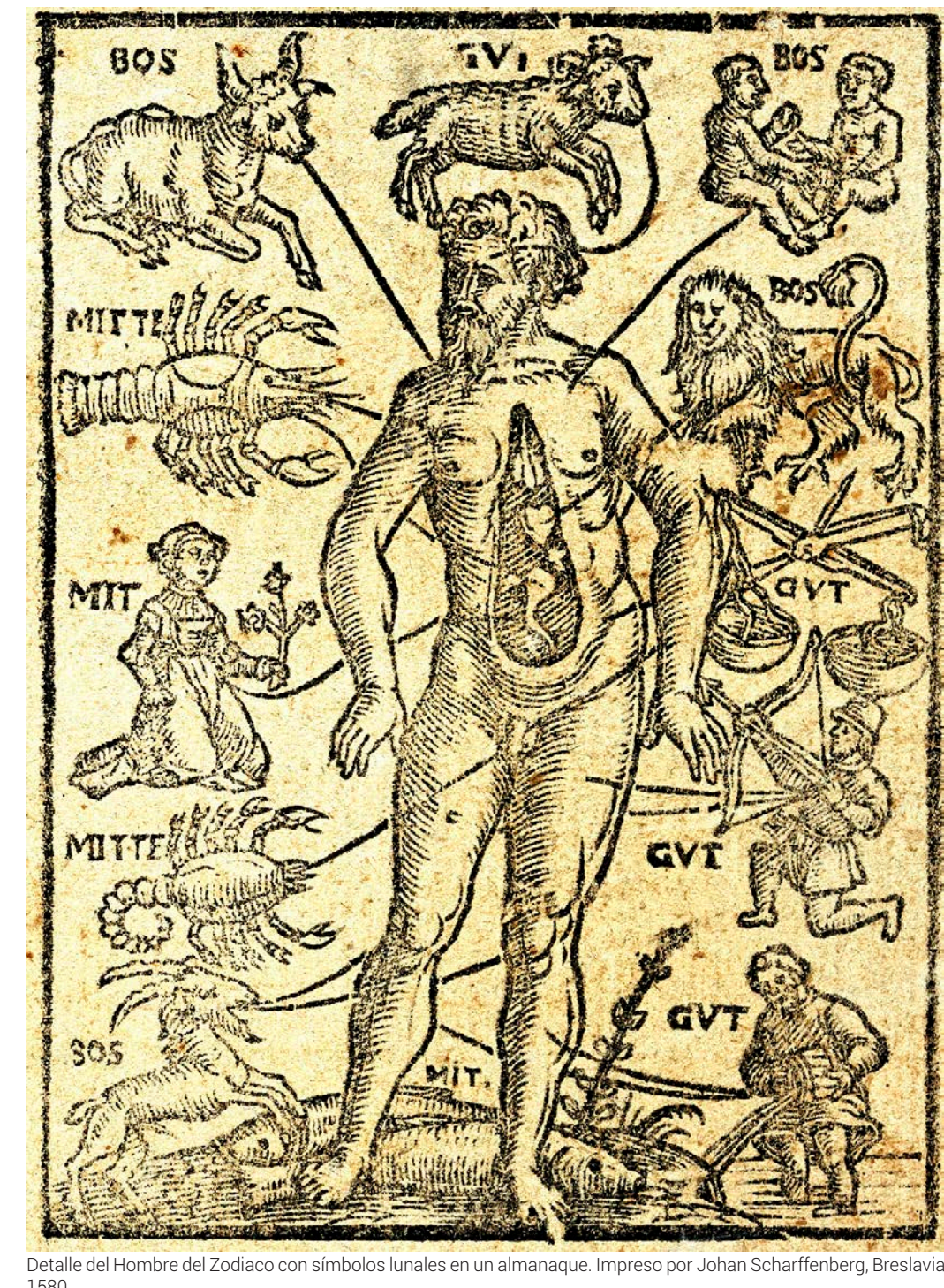

Detalle 1 i 1580.
150.
El cuerpo permeable La concepción que se tiene del cuerpo durante la Edad Media resulta medieval fundamental para entender su razonamiento. El cuerpo medieval es totalmente dependiente de las fuerzas cósmicas, habitado por los signos del zodiaco e inmerso en el ciclo de los planetas y de las estaciones $^{88}$. No es un ente separado y aislado de su entorno, sino un ser más o menos 'permeable': un organismo poroso que está en continua comunicación con el medio ambiente; es decir, con las miasmas, los fluidos y otras materias ${ }^{89}$ que constituyen el principio del desorden ${ }^{90}$

El concepto que se tiene del espacio doméstico durante el siglo XIV en Europa, donde no existe una clara diferencia entre el interior y el exterior, se traslada al cuerpo reforzando la idea de la penetración ${ }^{91}$ 92: se cree que la superficie de la epidermis es permeable, pudiendo el agua y el aire corrupto traspasar sus débiles capas hacia el interior.

Las epidemias dela pestevan exacerbando una imagen delas fronteras corporales penetrables del cuerpo permeable, abierto al veneno, en la que el desconocimiento profundo sobre la piel y su funcionamiento hasta finales del siglo XVIII juega un papel fundamental.

La desaparición del baño de La preocupación, en consecuencia, es evitar cualquier situación inmersión de riesgo que pueda propagar la enfermedad Para ello se aísla a la población infectada en salas de hospitales; se busca limitar os intercambios y suprimir toda práctica que amenace con abrir los cuerpos al aire infeccioso. En este sentido, y a pesar de que lugares de reunión como las iglesias y las escuelas, cada vez menos frecuentados, generan desconfianza, sin duda son los baños públicos los grandes afectados. La creencia generalizada, legitimada por los médicos de la época ${ }^{93}$, de que la presión y calor del agua abre los poros y ablanda el cuerpo exponiendo a los órganos a la enfermedad provoca, entre los siglos XVI y XVIII, la demonización y el cierre de los baños. 


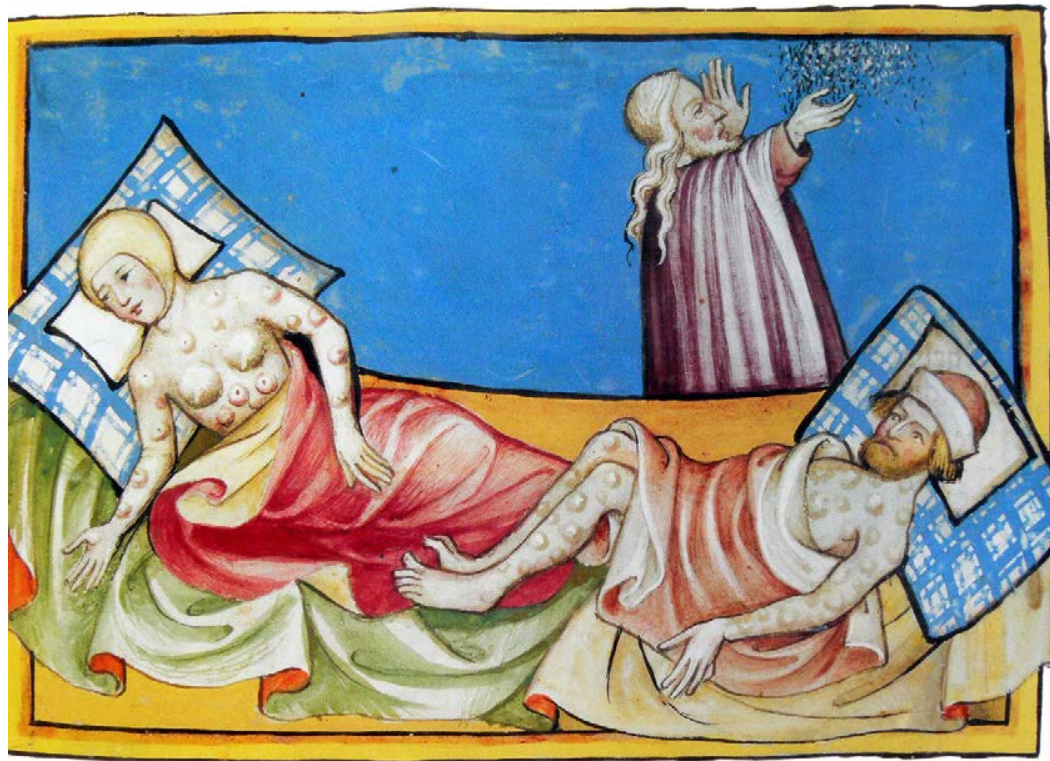

Ilustración mostrando a enfermos con bubones de la Peste Negra de la Biblia de Toggenburg, 1411.
La escasez de madera Junto a este principio de abertura ${ }^{94}$ de la piel, es decir, el de los cuerpos como combustible porosos y la propagación de la peste, surgen, alrededor de 1500, otros factores que resultan decisivos para el cierre definitivo de los baños y, por tanto, para el abandono de la limpieza corporal. Uno de ellos es la aparición de la primera crisis ecológica del continente ${ }^{95}$, cuando la urbanización intensiva debido al aumento de la población previa a la extensión de la peste provoca una paulatina deforestación y alejamiento de los bosques. De esta manera se dificulta la obtención de la leña, el combustible necesario para calentar el agua de los baños.

La importación de la sífilis Desde otro punto de vista, el descubrimiento del Nuevo Continente en 1492 trae consigo la importación de la sífilis ${ }^{96}$, una enfermedad de transmisión sexual que encuentra en la degeneración de los baños públicos en los burdeles una vía de propagación entre la población.

Finalmente, el establecimiento de un nuevo orden moral en el siglo XVI, bajo la influencia de la Reforma y la Contrarreforma ${ }^{97}$, donde el alma y el cuerpo son el centro de su mirada y la desnudez se considera un pecado ${ }^{98}$, es el responsable de la desaparición definitiva del baño de inmersión en el paisaje urbano. Desde entonces, y hasta el siglo XVIII, se pierde el sentido más elemental de la limpieza99 100.

La Contrarreforma En apenas cien años, la ideología con respecto al agua, vinculada a la representación del cuerpo medieval, se transforma. El mismo líquido que hasta el siglo XIV es el símbolo del juego, del placer, de exceso y la transgresión en los baños públicos, ahora es exorcizado y considerado culpable de causar el contagio entre los cuerpos, despertando un temor inédito debido a una concepción que, desde la ignorancia, imagina al organismo como un medio poroso capaz de ser atravesado por flujos peligrosos. Desde finales de la Edad Media y hasta la mitad del siglo XVIII la limpieza corporal, tal y como nosotros la conocemos, prescinde del agua e ignora el cuerpo ${ }^{101}$. 
El antropocentrismo El conjunto de acontecimientos religiosos, morales, políticos y económicos que suceden al final de la Edad Media se corresponden con un cambio de paradigma en la conducta humana, que tiende, por vez primera, hacia un pensamiento individualista. La emergencia moderna del individuo se traduce en unas nuevas formas de vida que, como ya se ha explicado en el capitulo anterior, por encima de todo se centran en la voluntad de cada persona de distinguirse de los demás.

De esta manera, el proceso civilizatorio, iniciado en el medievo y difundido a través de los primeros tratados de cortesía, encuentra su continuidad en el siglo XVI, dando lugar a un complejo movimiento de transformación de las pautas de comportamiento que se extienden hasta los siglos XVIII y XIX. La desnudez, por ejemplo, algo cotidiano entre la aristocracia, desaparece coincidiendo con la aparición de un sentimiento de vergüenza que se refleja en el uso, a partir del siglo $\mathrm{XVI}$, de la vestimenta nocturna o el pañuelo para la nariz ${ }^{102}$.

La invención del tenedor Entre las nuevas costumbres individualizadoras que aparecen en el siglo XVI, y que afectan a la limpieza personal, destacan aquellas que están vinculadas a los hábitos de la mesa. Si hasta finales del periodo medieval lo frecuente es que el grupo de comensales se lleve el alimento directamente a la boca con la mano, mientras comparten tazones y copas, a partir de la popularización del tenedor de tres puntas, en 1500,103, se produce una individualización de los modos de comer ${ }^{104}$ 105. Esta situación separa al individuo de lo colectivo, a la vez que implica un cambio en la regulación de los impulsos, las emociones y los escrúpulos ${ }^{106}$

Desde entonces, la costumbre de lavarse las manos tres veces a lo largo de una comida, impuesta por los libros de etiqueta medievales, desaparece, puesto que el comensal ya no se ensucia tanto como antes. De este modo, y como consecuencia de la transformación de la técnica en la mesa, durante el siglo XVI se produce un desplazamiento de la posición del aguamanil, que pasa de estar en la sala multifuncional a ocupar un lugar próximo a la cama, marcando de ahí en adelante una evolución hacia el lavabo y también hacia la limpieza corporal real.

102 ELIAS, Norbert. Op.cit. 205

103 A partir del siglo XVI el tenedor viene de Italia y llega a Francia, y luego a Inglaterra y a Alemania, y comienza a utilizarse como instrumento de mesa, al menos por la clase alta, tras haber servido 
El lavado de las partes Una vez que desaparece la práctica del baño de inmersión del paisaje visibles del cuerpo de la ciudad y del espacio doméstico, por temor al agua que se infiltra y corrompe los humores internos, el aguamanil se convierte, hasta el siglo XVIII, en uno de los medios de limpieza del cuerpo que a partir de entonces se limita a las partes visibles que deja descubierta la indumentaria: el rostro y las manos ${ }^{107}$.

Si bien tener las manos limpias y el rostro liso es un código socia frecuente durante la Edad Media, que se realiza más por obligación moral y decencia que por estar limpio, paradójicamente este hábito se mantiene a partir del rechazo del agua, aunque con ligeras modificaciones.

La ausencia del agua no significa que no exista una preocupación por la limpieza. Por contradictorio que pueda parecer, a la vez que desaparece este líquido de las prácticas de limpieza aumentan las normas de aseo y esmero ${ }^{108}$ que son ampliamente difundidas a través de los libros de salubridad, de las normas de cortesía y de los tratados de urbanidad, que hablan precisamente de ciertos olores de cuerpo y de su necesidad de hacerlos desaparecer.

El aseo seco A partir del siglo XVI, el aseo debe ser, al mismo tiempo, 'seco' y activo $^{109}$, ejecutado preferentemente por las mañanas, nada más despertar. Mientras que la limpieza del rostro, que es una parte 'frágil' de la anatomía, se realiza enjugando y frotando con un trapo blanco perfumado para quitar la mugre ${ }^{110}$, el agua, que tiene un uso limitado y preciso, se reserva para el lavado de las manos y la boca ${ }^{111}$. Con frecuencia el agua se mezcla con otros líquidos, como el vinagre en el caso del enjuague bucal y el vino para el lavado de las manos, con el objetivo de rebajar su composición química y alterar su pureza.

La importancia de estas prácticas de ablución parcial radica en que, por primera vez, significan una sistematización de las normas de limpieza, y, por tanto, un primer paso hacia una 'higiene' regular, pudiéndose considerar como antecedente de las actuales, a pesar de que funcionan de manera muy diferente ${ }^{112}$. 


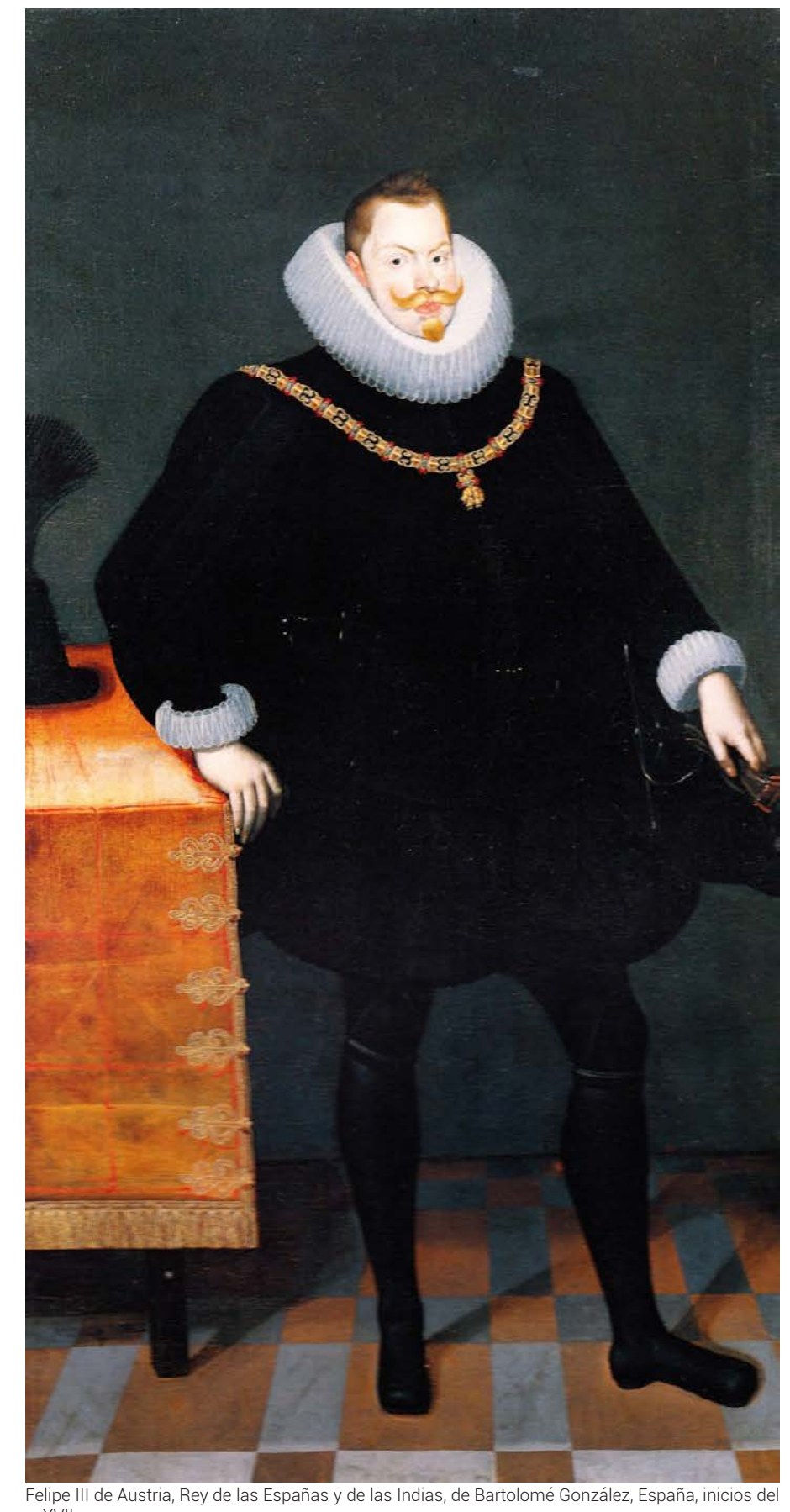

s. XVII.
La vestimenta como medida Junto al lavado de las partes visibles del cuerpo aparece durante los de limpieza siglos XVI y XVII otro mecanismo de limpieza seca, la vestimenta113 Esta práctica, cuyo origen se encuentra en la Edad Media, cuando la indumentaria comienza a componerse de distintas prendas y capas que se oponen al simple paño del hábito, cumple una doble función. Por un lado protege al cuerpo poroso de los ataques de aire pútrido ${ }^{114}$ 115, pero también lo 'limpia' gracias a su renovación periódica.

De este modo, la muda periódica de la ropa -interior, traje o vestido- sustituye, entre los siglos XVI y XVIII, al lavado corporal estableciéndose como una regla de limpieza ${ }^{116}$. Lo que lava ahora es la ropa: el enjugado, la limpieza del sudor, equivale a una ablución, siendo incluso menos 'peligroso'117. La frecuencia de su muda, que no se especifica en los libros de cortesía118 pero que aumenta desde la segunda mitad del siglo XVII, hace desaparecer la mugre, consiguiendo una intimidad aceptable del cuerpo.

El cuello y los puños como La forma y calidad del vestido, pero sobre todo la ropa blanca, enjuga indicadores del 'aseo' y hace destacar en público la limpieza de la persona; distingue un interior y un exterior, separa lo de encima de lo de debajo, consiguiendo que la intimidad corporal se cargue de significados autónomos a través de distintos tipos de tejidos. En el caso de los vestidos, que desde el siglo XVI adquieren, entre la clase alta, más voluptuosidad, el cuello y los puños ${ }^{119}$ visibilizan el grado de limpieza de la persona a través de su blancura.

Finalmente, estas prácticas secas, que no son otra cosa que un enmascaramiento de la limpieza, se refuerzan, desde el siglo XVII, con la aparición de otros dispositivos corporales de 'camuflaje' como el uso de fuertes perfumes, polvos y pelucas cuyo objetivo es tanto hacer desaparecer el olor que el cuerpo desprende como aparentar ${ }^{120}$

113 VIGARELLO, Georges. Op.cit. 13

14 VIGARELLO, Georges. Op.cit. 23 .
15 Con el fin de que el aire corrupto no entre en el cuerpo se usan tejidos lisos, tramas compactas, y todo ceñido firmemente al cuerpo. La vestimenta más
adical la portan los llamados Doctores de la Peste que son especialistas que tratan a aquellos que tienen la enfermedad y para elllo no solo cubren su cuerpo por completo, sino también su rostro con unas máscaras que parecen picos de ave y a las que impregnan con un líquido aromático supuestamente para mantener alejada a la peste.

116 VIGARELLO, Georges. Op.cit. 82

118 Aunque en siglos anteriores las reglas de las comunidades son explíitas en relación a la frecuencia de ciertos aseos, como el lavado del pelo o de dientes no se especifica, sin embargo, nada sobre la muda de la ropa interior. Posiblemente el aspecto más positivo que encontramos en la desaparición del baño de inmersión en el siglo XVI es el impulso que la muda de la ropa interior y del vestido, actualmente vigente en nuestras sociedades, recibe, al convertirse en una regla de limpieza.

ARIES, Philippe y DUBY, Georges. 1987/vol 5. 190

120 Los perfumes de las mujeres y los tónicos de los hombres se elaboran en los siglos XVI y XVII con aceites que frecuentemente causan erupciones cutáneas el pulverizador todavia no se ha inventado se elige a una criada con potentes pulmones a la que se le enseña a llenar la boca de buches de agua perfumada para que luego lance a través de sus dientes una lluvia finísima de agua, babas y perfume en dirección al rostro de la señora de la casa. 


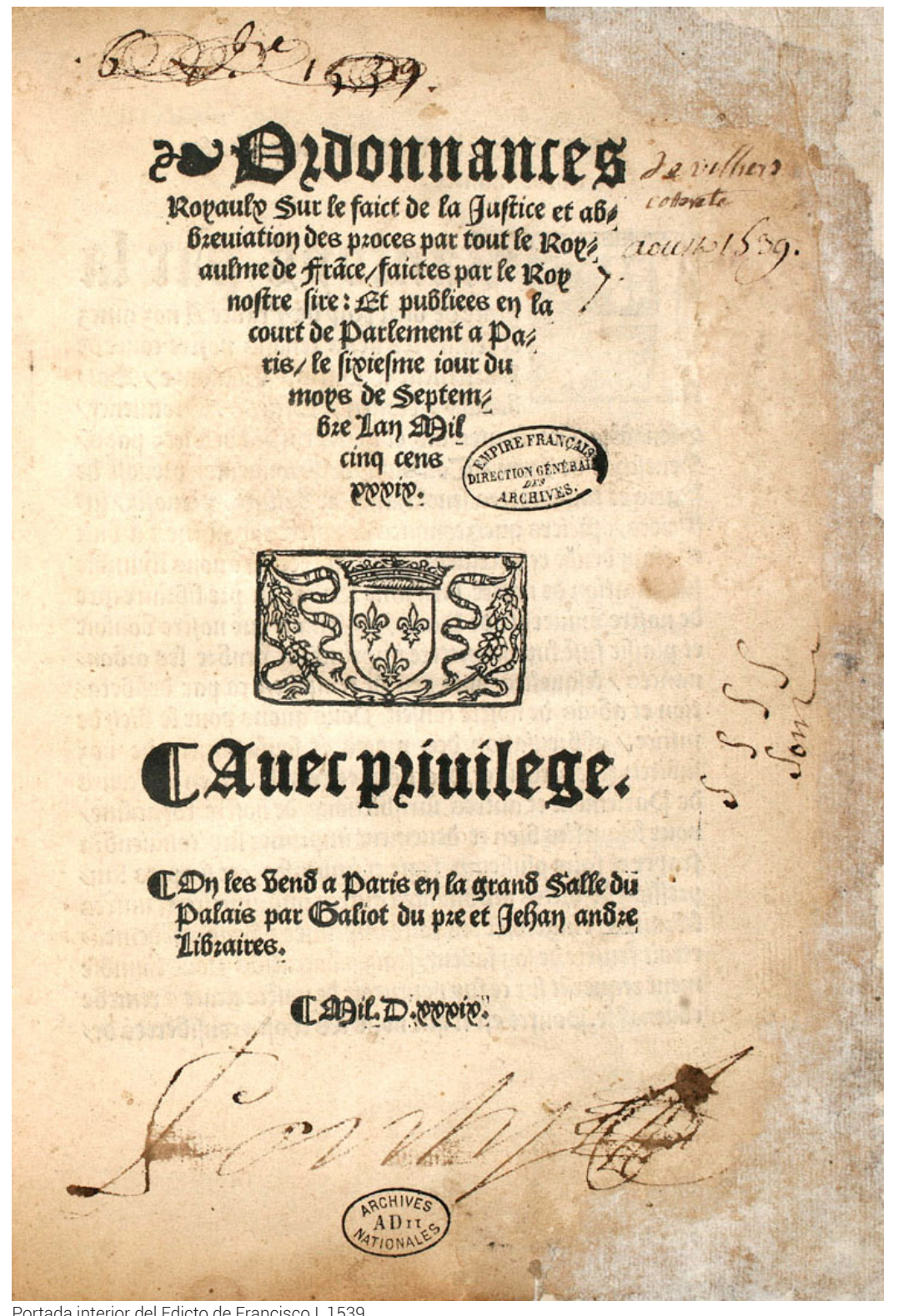

Portada interior del Edicto de Francisco I, 1539
La apariencia Sin duda todos estos mecanismos de limpieza seca no son acciones y el espectáculo dirigidas al bienestar y al confort personal, sino hacia los demás Estas prácticas de apariencia constituyen un dispositivo material de ocultación que, disimulando la superficie/forma del cuerpo, cumplen con los nuevos ideales religiosos tras la Reforma, donde la carne es pecado; a la vez dan lugar a un nuevo concepto de intimidad.

Independientemente de la salud, durante casi doscientos años ser limpio es mostrarse limpio, ya que lo importante es lo inmediatamente visible, la apariencia. Son precisamente la creciente importancia que adquiere el sentido de la vista, el indicio más intuitivo -el que convence de un modo más natural-, en el siglo XVI, junto con la transformación de la actitud frente a las necesidades naturales ${ }^{121}$ dos de las principales causas del comienzo de la transformación de las ciudades.

El aumento del tamaño y densidad demográfica que experimentan núcleos urbanos como París y Londres en el siglo XVI, junto al abandono de la construcción de las letrinas en las viviendas urbanas ${ }^{122}$ provocan un empeoramiento aún mayor de las condiciones de salubridad de las calles, donde desde hace tiempo todo rincón, plaza o portal se considera apropiado para evacuar.

Esta situación de suciedad comienza a preocupar a las autoridades sanitarias. Si bien es cierto que desde la consolidación de la ciudad occidental, en el siglo XII, existen diversas ordenanzas que, sin apenas éxito, buscan regular las materias fecales en la ciudad, no es hasta el siglo XVI cuando estas adquieran importancia. 
Edicto de noviembre de 1539.

Francisco, rey de Francia por la gracia de Dios, hago saber a los presentes y venideros que villa y ciudad de París y sus alrededores están en muy mal estado y arruinados $y$ abandonados hasta tal punto que en muchos lugares no $s$ puede circular tranquilamente, ni a caballo ni en coche, sin gran peligro $e$ inconveniente $y$ de que a tal odos, besures, que cada uno va dejando y abandonando diaria mente ante su puerta contra todo buen juicio y contra las ordenanzas de nuestros predecesores de modo que causa gran horror y disgusto toda persona de bien $y$ de honor y provocan ns de los habitantes $y$ transeúntes de nuestra dicha villa y alrededores, los cuales, por la infección y la fetidez de los dichos lodos, excrementos y otros desperdicios, están expuestos con el paso del tiempo, sin razón alguna; consideramos, por todas las cosas arriba citadas, y expuestas tam-
bién por varias gentes de nuestro consejo y otras personalidades notables, que es necesario e imperioso poner en breve plazo provision y remedio conveniente para el buen gobierno de nuestra dicha villa y alrededores, a la cual profesamo especial afecto, pues es la principal y más notable de nuestro reino; hemos establecido $y$ orde mos por edicto perpetuo, estable e irrevocable. las cosas que aquí se siguen:

Art. 4. Prohibimos vaciar o arrojar a las calles y plazas de la citada villa $y$ sus alrede. dores, basuras, agua de colada, agua infectada o de cualquier otro tipo, así como retener en las
casas durante tiempo orines y aguas corrompidas casas durante tiempo orines y aguas corrompidas
0 infectas; así, les instamos a acarrearlas $y$ vaciarlas de inmediato al arroyo y echar luego un cubo de agua limpia para darles curso.

Art. 15. Prohibimos a toda persona, sea quien fuere, vaciar $y$ arrojar a la calle pajas, dicias, quemar estas en la calle, hacer mata cerdos $\mathrm{u}$ otras bestias $\mathrm{y}$ les instamos, muy al contrario, a que estas basuras e inmundicias sean cerradas y puestas en sus casas en cestos de

Art. 21. Ordenamos a todos los propietarios de casas, hostales y pensiones donde no haya ninguna fosa de retrete que, inmediatamente, ra y con toda diligencia, la manden

Algunos artículos del Edicto de Francisco I, 1539. Dominique Laporte.
El Edicto de 1539 En este sentido, la ordenanza más importante y tardía que existe es la del Edicto de Francisco I, en el año 1539. En él se recoge la preocupación del rey por la ruina y el abandono de la ciudad de París, expuesta a la infección y fetidez de lodos, excrementos y otros depósitos, contra todo buen juicio y contra las ordenanzas precedentes ${ }^{123}$.

De este modo, en los artículos 4 y 25 del Edicto se indica la obligación a todos los propietarios de casas, hostales y pensiones de disponer de una fosa de retrete en su interior, además de prohibir vaciar o arrojar cualquier materia por la ventana bajo pena de desahucio ${ }^{124}$ La mierda, que es un asunto privado de cada individuo, a partir de estas regulaciones se convierte por primera vez en una preocupación pública que el Estado asume, ordena y que hay que resolver en el interior del perímetro de la vivienda propia.

La imposición de introducir el retrete en el dominio doméstico, aunque sea exterior, pone de manifiesto un cambio de paradigma respecto a los desperdicios que tiene su origen no tanto en el sentido del olor como en la importancia del sentido de la vista. A través de estas políticas visuales implícitas en el Edicto, que busca mantener la ciudad de París aseada y bien ordenada ${ }^{125}$, se impone una evidente domesticación y privatización del excremento.

Por primera vez la ideología de lo limpio no se separa de la ideología de la propiedad ${ }^{126}$. La individualización del desperdicio y su instauración en la esfera de lo privado convierte el acto de la defecación en algo más íntimo respecto al siglo anterior, donde la equivalencia de los términos retretes y privados sirve para designar los lugares en los que, de ahora en adelante, se realizan las necesidades y por tanto se acumulan los desperdicios.

Desde entonces, la imagen de la ciudad, hasta ahora abandonada al paisaje de los excrementos y el orín, es devuelta a la mirada dando una imagen de un orden en el que la higiene, de momento, parece ser algo secundario. Desgraciadamente, y a pesar de esta normativa, la costumbre de defecar al aire libre continúa, incluso en la aristocracia, hasta el siglo XVIII, momento en que se comienzan a poner en práctica estas ordenanzas, a partir del progresivo descubrimiento de las características de la piel. como retener durante tiempo en las casas orines y aguas corrompidas o infectas;' 'asi, les instamos a acarrearlas y vaciarlas de inmediato al arroyo y a echar ninguna foso de retrete que inmediatamente, 


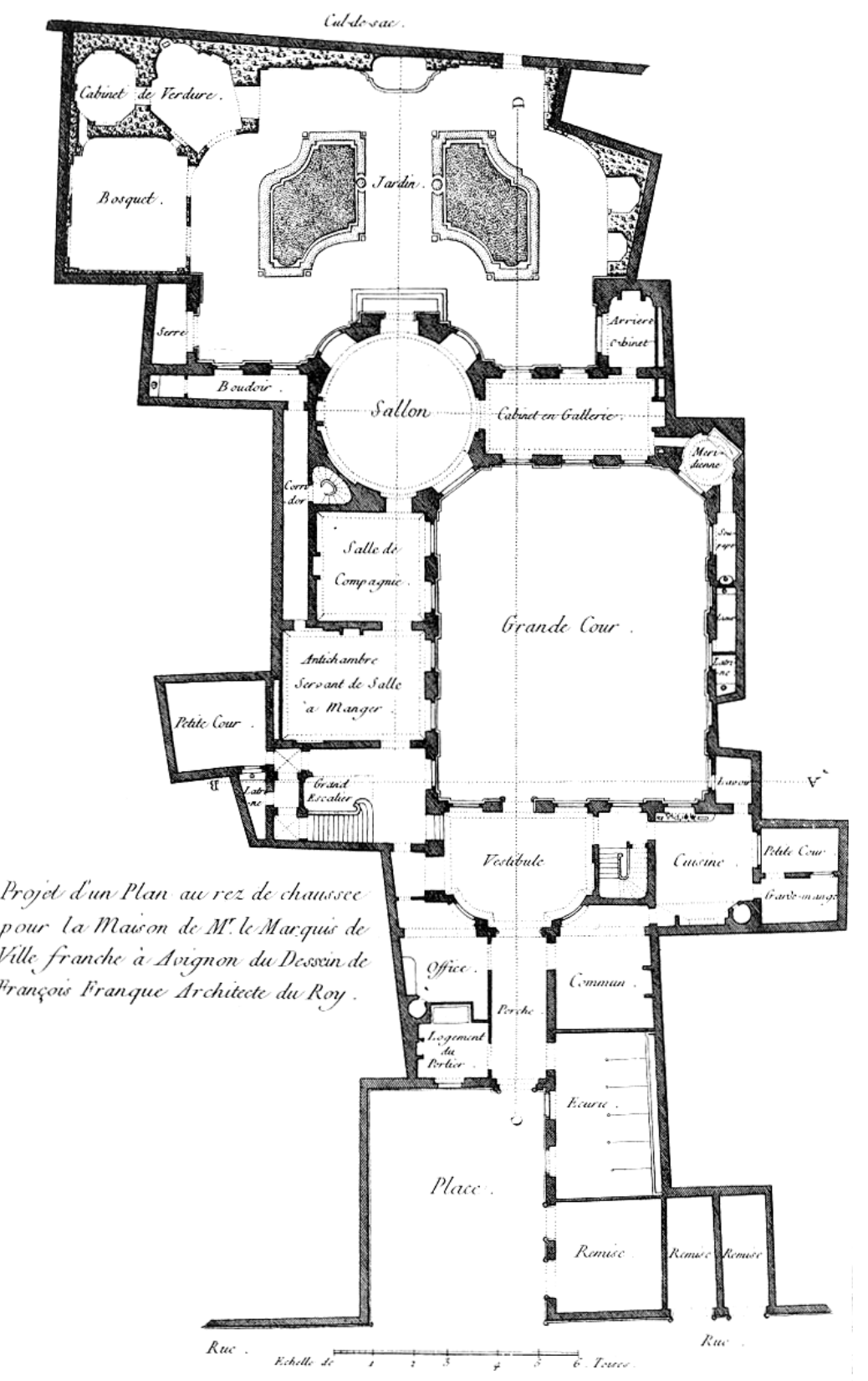

Planta del hôtel del marqués de Villefranche, Aviñón, Francia, publicada en la Enciclopedia de Diderot en '́r.m. 1792. En azul el boudoir.
La especialización espacial A la vez que las ciudades comienzan su embellecimiento con la de la casa retirada de los desperdicios de sus calles, los interiores domésticos se transforman como consecuencia del proceso de individualización. Si hasta el siglo XVII la vivienda está constituida por una serie de espacios polivalentes y la intimidad es algo desconocido, a partir de entonces aparecen en París, la principal ciudad de la Europa de 1600, los tipos de casas que recogen estas transformaciones que buscan preservar la existencia privada ${ }^{127}$. Así, mientras que los únicos reductos de intimidad durante la Edad Media se reducen a los huertos, los bosques y los marcos de las ventanas donde tienen lugar tantas historias de amor protagonizadas por damas y caballeros ${ }^{128}$, a partir del siglo XVII, con la especialización de la casa, los espacios de intimidad no solo quedan dentro de la casa, sino que se multiplican.

Como se ha visto en el capítulo uno, la casa burguesa típica de París se organiza en torno a un patio interior y continúa ocupando la parcela medieval, solo que ahora con cuatro o cinco piso de altura en vez de dos. Los pisos bajos contienen un espacio comercial y establos, además de la residencia del propietario y su familia, sus sirvientes y sus empleados ${ }^{129}$.

Aunque el número elevado de sus residentes y la diversidad de sus actividades continúa siendo claramente medieval -allí se aloja más de una familia-, durante esta época comienza una definición del programa de la vivienda en el que las distintas habitaciones reciben un nombre y un uso relacionado con el acto que en ella se realiza; evidentemente, el baño solo está presente por excepción.

A la habitación principal se le llama salle; es un espacio grande parecido al hall inglés, que se utiliza para comer, pasar el rato y recibir visitas. La cocina, explicada en el capítulo anterior, se dispone como espacio independiente separado del resto de la casa, al otro lado del patio. A pesar de que en el siglo XVII todavía existe gente que duerme en la sala, en camas abatibles, aparece una nueva habitación para realizar en exclusividad esta actividad, la chambre. También hay cuartos secundarios conectados con el dormitorio, como el garderobe, que no debe confundirse con el retrete medieval, ya que en este caso se trata de un guardarropa, y el cabinet o despensa. Ambos espacios, que comienzan siendo apéndices de las habitaciones, en el siglo XVIII adquieren autonomía y se define su amplitud. 


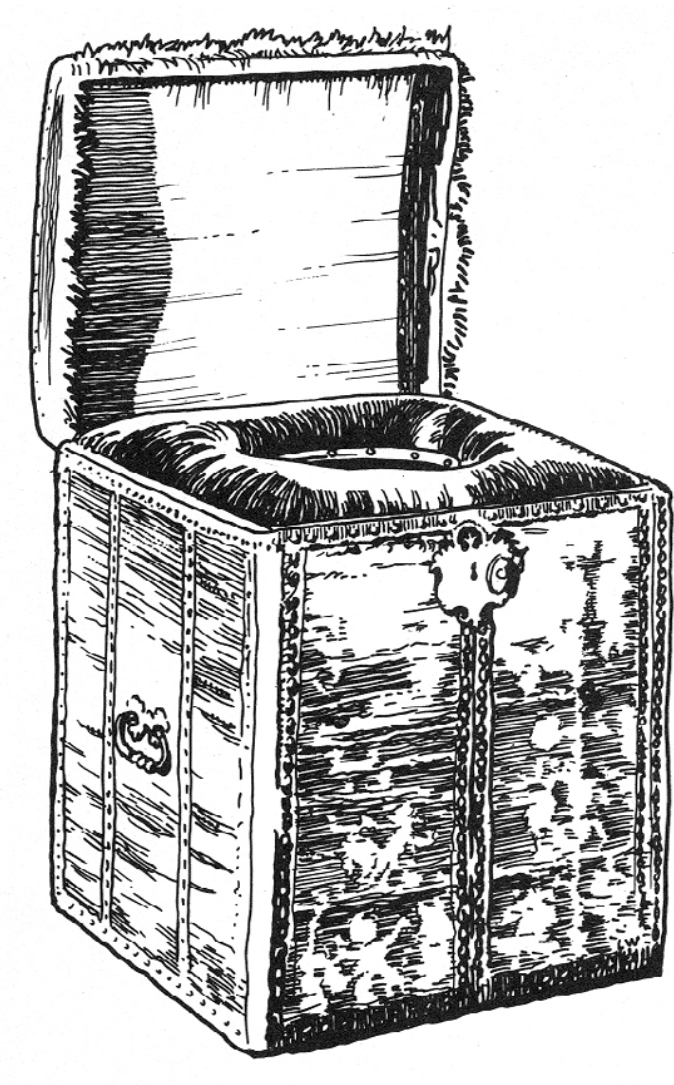

Sillico real en el palacio de Hampton Court, Inglaterra, 1600
En el siglo XVII, la casa típica parisina se empieza a asemejar a un edificio de apartamentos. La existencia de viviendas de alquiler en los pisos altos supone la separación de la vivienda y el trabajo, al haber mucha gente para la que la vivienda es exclusivamente una residencia ${ }^{130}$

Paralelamente a la privatización de la casa, intimidad precaria ligada al concepto de familia, la consideración del mobiliario de la casa como equipamiento de la Edad Media se transforma en el siglo XVII en posesión fundamental para abigarrar el espacio, transformado por primera vez en un escenario de teatro social ${ }^{131}$.

Los muebles parecen destinados a la presencia aparente en espacios sucesivos, ya que como todavía no existe el pasillo cada habitación da directamente a la siguiente, de modo que se goza de una visión continua desde un extremo de la casa hasta el otro.

El sillico móvil Entre la multitud de muebles domésticos que se pueden encontrar en la casa del siglo XVII de las clases dominantes está el que facilita la realización de las necesidades fisiológicas naturales; el sillico o la silla retrete ${ }^{132} 133$ aparece como consecuencia del notable avance de los límites de vergüenza que favorece la individualización, que no privatización, del acto de la defecación.

Este antecesor del retrete actual, del que no se sabe con exactitud su origen ${ }^{134}$, es un elemento portátil cuyo aspecto es una caja de madera forrada o un armazón de hierro con una tapa acolchada que oculta en su interior un bacín extraíble que los sirvientes -mozos del bacín o portasillas- traen a la habitación cuando los aristócratas la necesitan. Una vez que se ha usado, tras limpiarse el ano con estopa de lino, precursora del papel higiénico, el contenido, en el caso de la alta nobleza, suele ser inspeccionado por un médico ante de ser desechado con el fin de cuidar a los futuros posibles reyes ${ }^{135}$. 


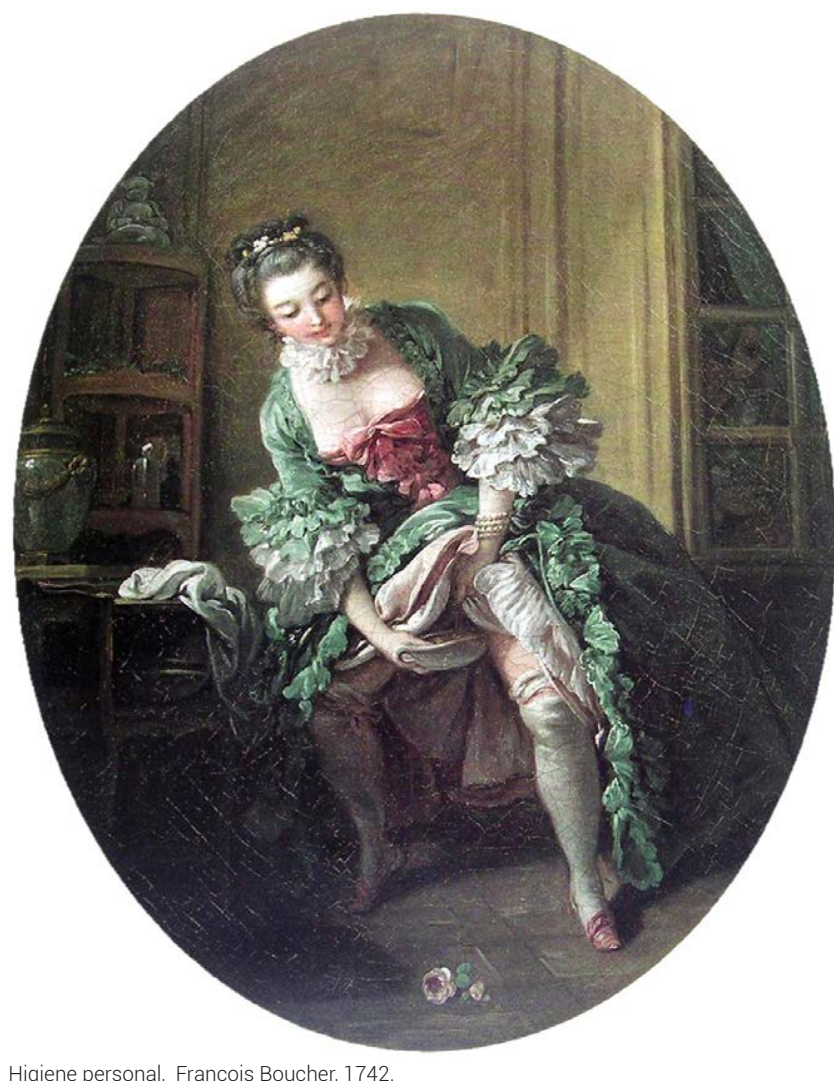

Higiene personal, François Boucher, 1742

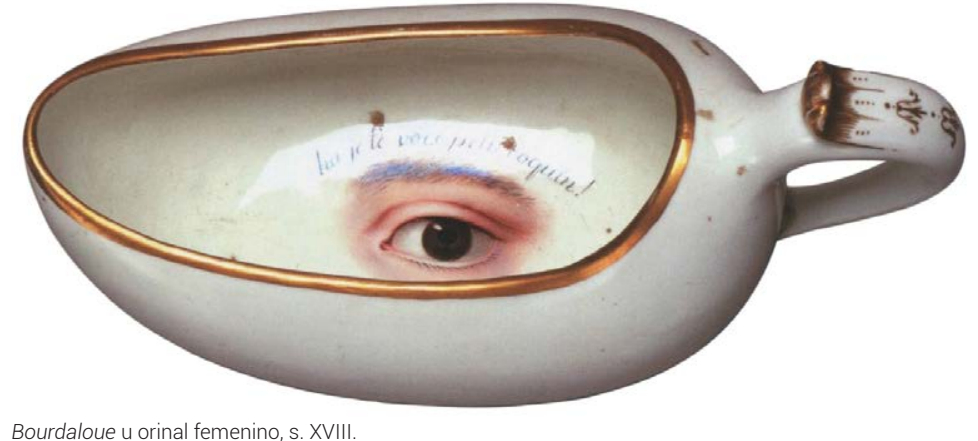

Bourdaloue u orinal femenino, s. XVIII. sillico es una solución que reúne en un mismo objeto las ventajas del orinal, que no requiere de conductos de alcantarillado y puede ser transportado a cualquier habitación, con las comodidades del asientoletrina. Revestidas con terciopelo orlado con cenefas, bordadas con franjas, estas obras de ebanistería contienen un bacinillo de loza o de plata, y a veces hasta cuentan con un velador que permite leer y escribir ${ }^{136}$.

El bourdaloues En la habitación contigua al dormitorio generalmente se dispone el garde-robe ${ }^{137}$, que en el siglo XVIII pasa a llamarse retiro-retrete ${ }^{138}$ 139. En la misma habitación del dormitorio también es frecuente la presencia de otros elementos portátiles para orinar como el bourdaloues, u orinal adaptado a la fisiología femenina, de forma ovalada con un ojo pintado en su fondo ${ }^{140}$, y el perico ${ }^{141}$, una vasija de vidrio, barro cocido o metal -latón, peltre, cobre, plata y oro- con un cuello estrecho y una boca ancha que tiene las ventajas de poderse utilizar cuando el usuario está metido en la cama y servir para analizar el pis visualmente.

En cualquier caso, todos estos dispositivos son exclusivos de las clases altas. No es hasta el siglo XVIII cuando el sillico en particular alcanza a todas clases sociales, quienes durante el siglo XVII continúan haciendo uso del ya clásico bacín para realizar sus funciones de evacuación. 
La casa íntima del s. XVIII Si bien a lo largo del siglo XVII la casa occidental se convierte poco a poco en un lugar cada vez más privado, lo cierto es que esta situación alcanza su máximo exponente en la vivienda holandesa de ese mismo siglo, explicada en el capítulo anterior, gracias a la reducción de la esfera de lo privado a la célula familiar como ámbito principal de afectividad e intimidad. Una vez separadas las funciones públicas de las privadas, el trabajo de la familia, la intimidad y la domesticidad, a lo largo del siglo XVIII el modelo de vivienda holandés, explicado en el capítulo de la cocina, se difunde en Europa occidental.

Es cuando la casa pierde su carácter público para transformarse en contexto de una nueva unidad social compacta pero también aislada como la familia, y se reduce al dejar de ser un lugar de trabajo para convertirse en el lugar para el tiempo de ocio, tanto las cuestiones relacionadas con el diseño arquitectónico como con la decoración de interiores, e incluso el trazado de jardines, ${ }^{142}$ empiezan a reflejar la búsqueda de la idea de confortt ${ }^{143}$

El nuevo mobiliario burgués Dentro de este marco evolutivo de la elegancia a la comodidad, a lo largo de la centuria de 1700 el mobiliario de las casa más ricas adquiere una gran importancia. Son precisamente las mujeres burguesas y aristócratas francesas quienes, influidas por la nueva domesticidad introducida por la mujer holandesa, exigen muebles menos ceremoniosos y más cómodos ${ }^{144}$. Esto supone un paso importante en la evolución de la casa.

La producción de estos muebles corre a cargo de ebanistas ${ }^{145}$ europeos, sobre todo franceses e ingleses, como Charle Cressent, Thomas Sheraton, George Hepplewhite o Thomas Chippendale. Aunando criterios decorativos y por primera vez ergonómicos, estos ebanistas comienzan a diseñar y a vender muebles por catálogo y para todas las clases sociales ${ }^{146}$, una diversidad de tipos de muebles que reflejan la especialización que se está produciendo en la casa. Las diferentes habitaciones van adquiriendo funciones diferentes. La gente ya no come en la antesala, sino en un comedor adecuadamente amueblado. Y tampoco recibe a los visitantes en sus dormitorios, sino en un salón. Todas estas habitaciones son más pequeñas, menos grandiosas y más íntimas que en el pasado ${ }^{147}$.
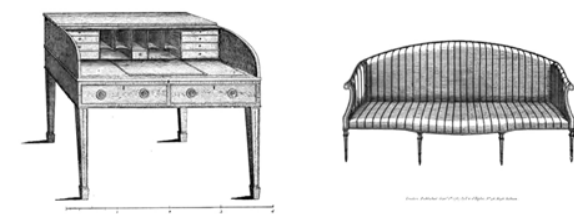

Páginas del catálogo del ebanista Thomas Chippendale, Reino Páginas del car 1987/vol 7.72.

143 La segunda mitad del siglo XVIII es calificada como la Era de la Elegancia debido a la influencia del 'gusto francés' en la sociedad (WRIGHT, Lawrence. Op.cit. 146). 144 RYBCZYNSKI, Witold. Op. cit. 103.

${ }_{45}$ La palabra ebanistería aparece por primera vez en el siglo XVIII para diferenciarla del término carpintería, ya que los artesanos ebanistas, además de las WRIGHT carpinteria, recurren a la marquetería, al chapeado y a la tabletterie.

147 RYBCZYNSKI, Witold. Op.cit. 95 


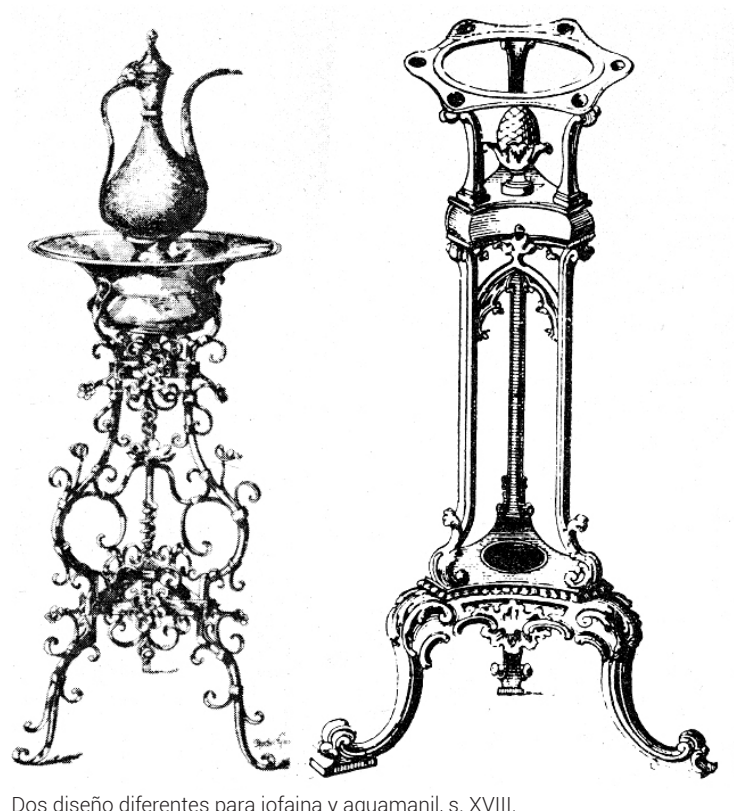

88

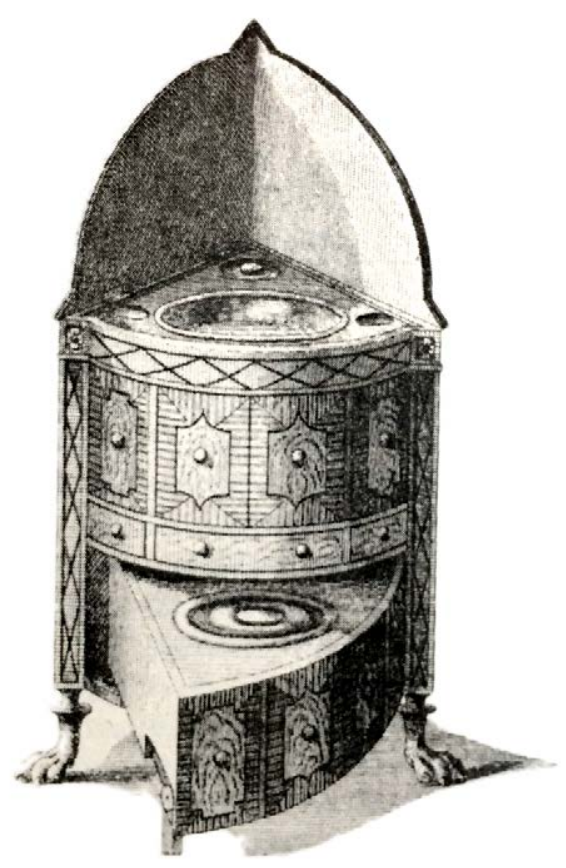

La popularización del pasillo, explicada en el capítulo anterior, hace que las distintas estancias se organicen no en largas filas comunicadas, sino de forma menos ceremoniosa, de tal manera que se puede llegar a una habitación sin pasar por otra.

El lávabo trípode Además de mesas para comer, sillas, cómodas y escritorios, entre los nuevos muebles del espacio doméstico se encuentran aquellos que trazan la evolución de las actividades de limpieza del cuerpo. El aguamanil portátil medieval, que desde el siglo XVI permanece cerca de la cama, a partir de 1740 sufre una primera transformación cuando se estabiliza, convirtiéndose en un frágil trípode con una pequeña jofaina o bandeja de porcelana encajada en un hueco ${ }^{148}$ significándose como claro precursor del lavabo actual. En su parte inferior, a veces cuenta además con un estante para disponer un minúsculo jarro para el agua.

El lavabo de rincón Hacia 1770, el mueble del lavabo se traslada a un rincón del dormitorio mediante el rediseño de los ebanistas. La parte superior se transforma en un cuadrante con un pedestal, que se agranda para que la jofaina sea mayor, y a esta se le practican unos orificios para las jaboneras. Esta transformación no es solo un indicio del aumento del grado de intimidad, sino que formalmente provoca un cambio funcional respecto a los lavabos de pared del siglo XVI, ya que permite, además del lavado de manos, también el del pecho. 


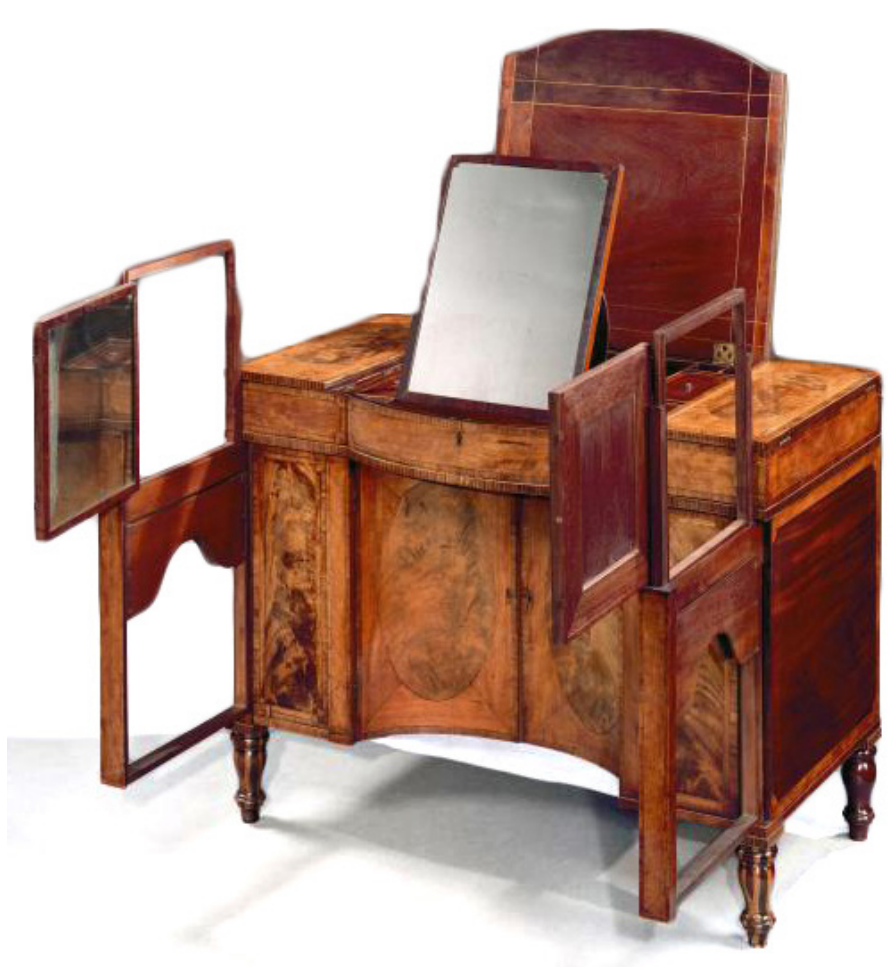

Original tocador de caoba y palo satinado con espejo escamoteable, s. XVIII.

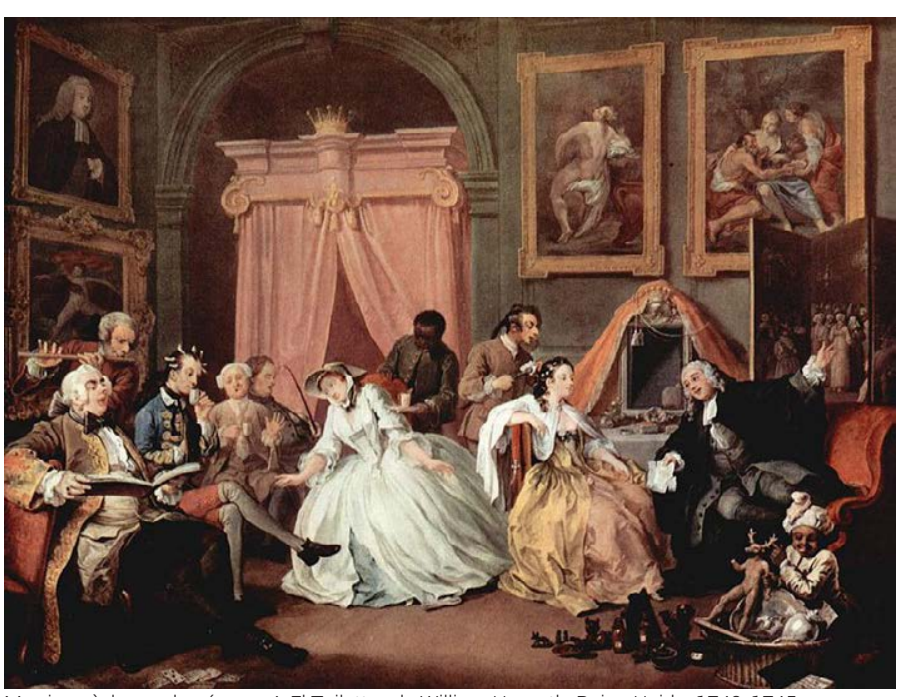

Marriage à-la-mode número 4: El Toilette, de William Hogarth, Reino Unido, 1743-1745.
El boudoir femenino Cerca del lavabo, en la habitación del tocador, una nueva estancia en la vivienda del siglo XVIII, aparece un mueble relacionado con un espacio-tiempo estrictamente femenino, el boudoir ${ }^{49}$. Como reflejo del aumento general del deseo de privacidad y la importancia que se le da al aspecto físico, sobre todo al de la mujer, los ebanistas diseñan un mueble de madera que aglutina muchos de los elementos que van a configurar, ya a finales del siglo XIX, el cuarto de baño: el retrete, el lavabo y el espejo ${ }^{150}$.

El toilette diaria Además de servir de escritorio y costurero, el boudoir cuenta con un espejo de cara para que la mujer se acicale. Entre las funciones que contiene esta morada del deleite sensual151 se encuentran las destinadas a limpieza corporal, ya que dispone de una pequeña escupidera roja que se utiliza después del enjuague bucal y una jofaina que permite realizar la toilette diaria, como ceremonia social de preparación para el día, que realiza la mujer nada más levantarse en presencia de visitantes eventuales. En realidad este acto es una materialización sofisticada evolucionada, a través del dispositivo mueble-bodouir, de una práctica que se viene haciendo desde la Edad Media cuando los manuales de cortesía insisten en el lavado de manos, cara y dientes todas las mañanas.

La presencia de una silla en el bodouir, en coherencia con la preocupación ergonómica del diseño de mobiliario, hace pensar que por primera vez muchas de estas funciones se tienen lugar sentados, deduciéndose que para su realización se va a invertir un tiempo de cierta duración y con cierto placer. 


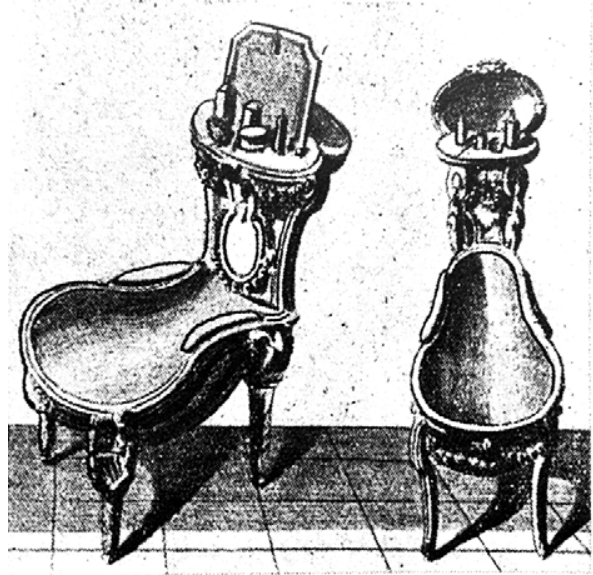

Bidé con espejo y tocador, s. XVIII.

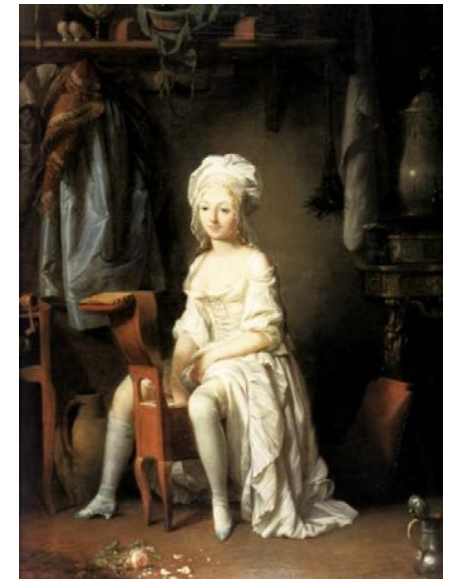

Mujer
1790.
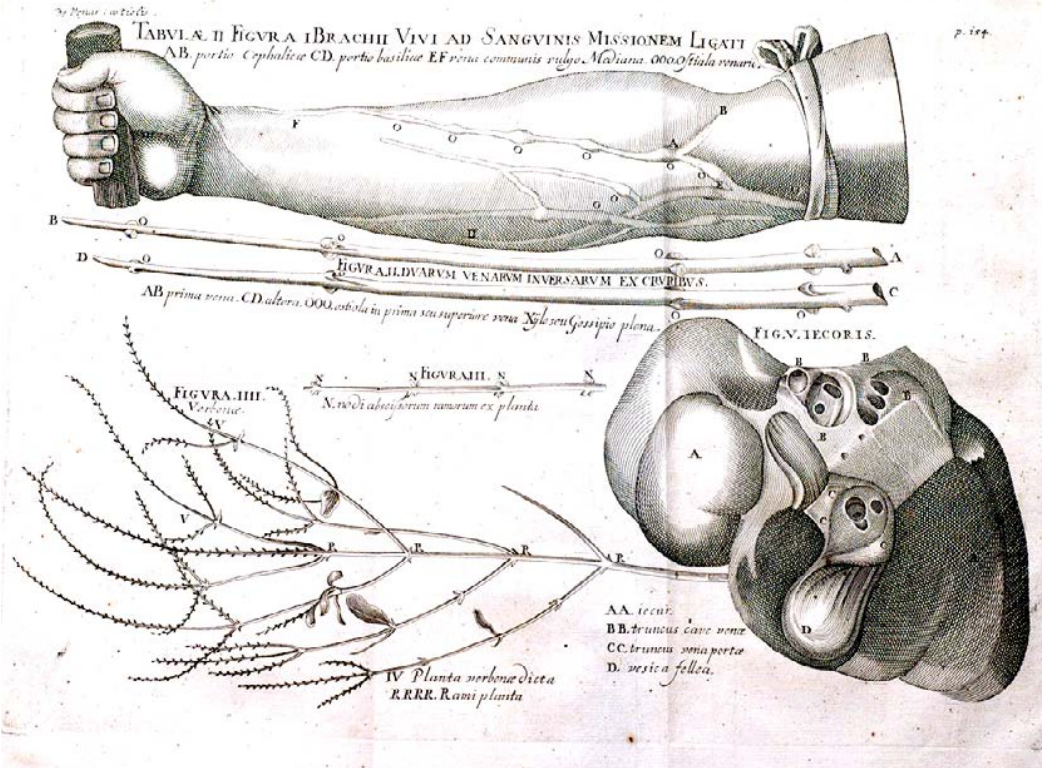

Dibujo realizado por William Harvey del sistema sanguineo del brazo en Exercitatio Anatomica de Motu Cordis et Sanguinis in Animalibus, 1628

El bidé Después de 1740, aparece un objeto inédito que se localiza en los inventarios nobles y en las cuentas de los grandes ebanistas. Es la 'caja de limpieza' o bidé ${ }^{52}$. Frente a otro tipo de muebles populares, el bidé es un instrumento que, durante mucho tiempo, denota una distinción social que se encuentra exclusivamente en el universo burgués, limitándose su presencia a la alcoba o al guardarropa; su función es la ablución local de las zonas 'secretas' del cuerpo ${ }^{153}$ con una periodicidad diaria.

Las nuevas teorías médicas

Es posible que tanto a la aparición del ritual de la toilette femenina, a través del boudoir -entendido como un mueble de aseo-, como a la presencia del bidé entre las clases altas, le precedan las nuevas teorías médicas que establecen, en el siglo XVIII, una revolucionaria comprensión del cuerpo, basada en la nueva relación entre el aire y la piel.

Destacan en esta cuestión los estudios del médico y filósofo alemán Ernst Platner. Según Platner, que en el siglo XVIII enumera los peligros teóricos de la suciedad corporal ${ }^{154}$, el aire es como la sangre y debe circular a través del cuerpo, donde la piel es la membrana que le permite respirar ese aire ${ }^{155}$, siendo la suciedad que la bloquea su principal enemigo. La mugre obstruye los poros, retiene los humores excrementosos, favorece la fermentación y la putrefacción de la materia ${ }^{156}$

Esta teoría de Paltner tiene su origen un siglo antes, cuando otro médico, el inglés William Harvey, cuestiona los antiguos principios del calor corporal. Frente a la idea de que la sangre fluye por el cuerpo a consecuencia de su calor, Harvey determina que la circulación producida de manera mecánica por el latido del corazón es la que calienta la sangre ${ }^{157} 158$. La nueva ciencia de la circulación subraya además la independencia de las partes del cuerpo, y, respecto a sistema neurológico, afirma que el cuerpo no necesita 'espíritu' para sentir; el alma puede estar en cualquier parte, pero la observación empírica no la localiza en ningún punto en particular. 152 VIGARELLO, Georges. Op.cit. 138.
153 VIGARELLO, Georges. Op.cit. 140. 154 CORBIN, Alain. 1987. 85. 155 SENETT, Richard. Op.cit. 280 156 CORBIN, Alain. Op. it. 85.
157 SENETT, Richard

158 Estas nuevas ideas sobre el cuerno coinciden con el nacimiento del capitalismo moderno y contribuyen a la gran transformación social que denominamos 'individualismo'. El individuo moderno es, por encima de todo, un ser humano móvil. (SENETT, Richard. Op.cit. 274). Los descubrimientos de la circulación de la sangre y la respiración en el cuerpo conducen a nuevas ideas acerca de la salud que por un lado guardan relación con la planificación urbana del siglo XVIIII y.

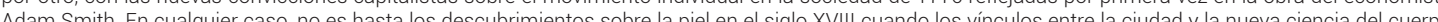



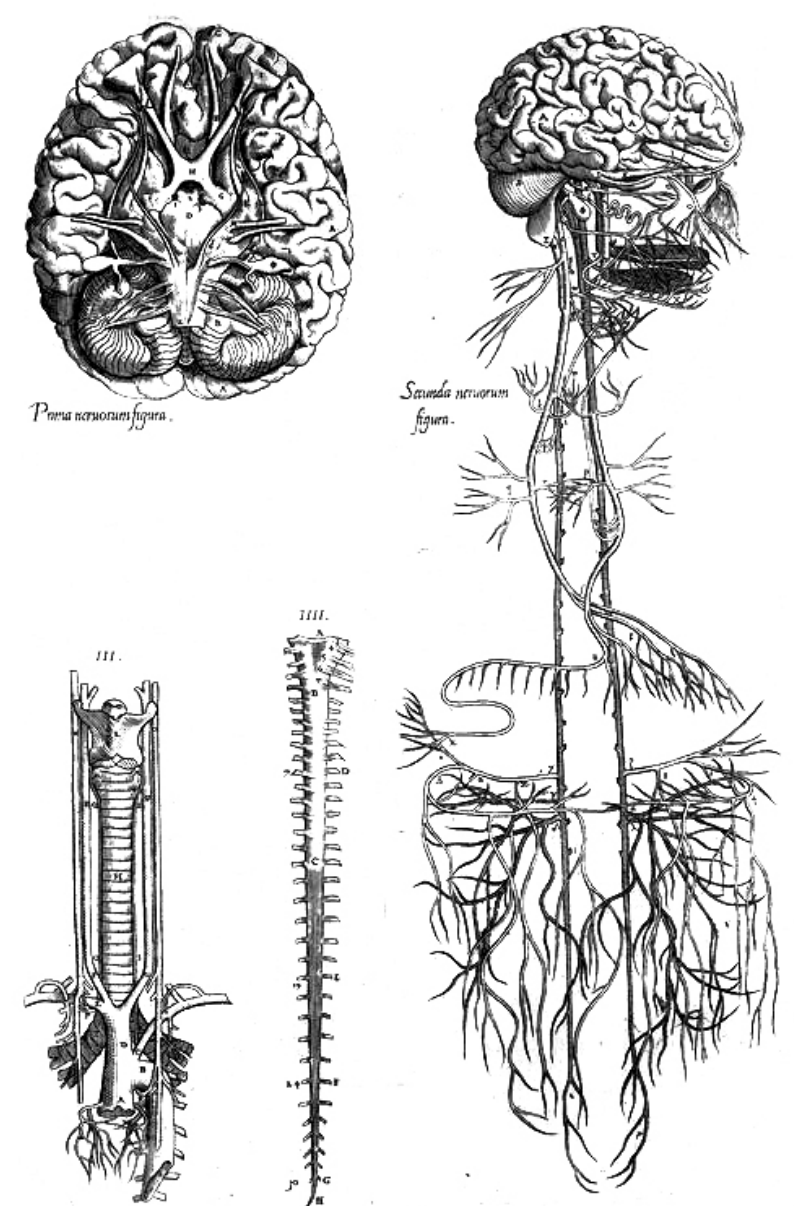

Dibujos del sistema nervioso, Thomas Willis, s. XVIII.

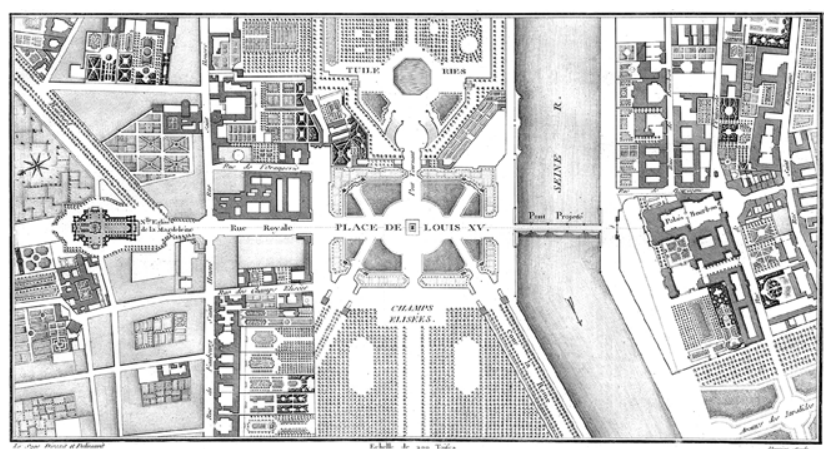

Plano de la place de Louis XV, París, Francia. Grabado de Perrier según Le Sage, s. XVIII.
A las investigaciones de Harvey le suceden, a lo largo del siglo XVII, otros estudios que desvelan el funcionamiento de la mecánica del cuerpo, tales como el descubrimiento del sistema nervioso por parte del médico Thomas Willis.

Los estudios de Harvey, Willis y Platner suponen una revolución médica sin precedentes que transforman por completo la compresión del cuerpo humano y su funcionamiento, conduciendo a nuevas ideas acerca de la salud pública. Desde entonces la moralidad parece ser sustituida por la salud, ahora definida por la circulación y el movimiento como modelo de felicidad humana ${ }^{159}$. Es precisamente este paradigma de flujo, salud e individualidad lo que finalmente transforma la relación entre el cuerpo y la sociedad.

La ciudad como el cuerpo Análogamente al cuerpo, la ciudad, que toma forma en el siglo XVIII, contribuye a traducir el paradigma interno en una imagen de un organismo sano en una sociedad sana ${ }^{160}$. Los mismos mecanismos de circulación y respiración que desde el siglo XVII se aplican al cuerpo comienzan a ponerse en práctica en las ciudades europeas, transformándose su aspecto entre otras cosas porque desde mediados del siglo XVIII se retira la basura de las calles y se conduce la suciedad hacia las cloacas.

Frente al trazado medieval urbano sin forma, el deseo de los planificadores ilustrados es que la ciudad, que ahora opera de una manera muy parecida a la circulación de la sangre por el organismo, con unas consecuencias revitalizadoras semejantes, funcione como un cuerpo ${ }^{161}$. La justificación del trazado de las ciudades del siglo XVIII se basa en el sistema circulatorio del cuerpo, donde las venas y arterias ahora son las calles y tanto el pulmón como el corazón son referencias importantes. El objetivo principal de las nuevas ciudades es, análogamente al modelo de la circulación de Harvey y Platner, que el aire, el agua y los productos de desecho también se mantengan en movimiento. 


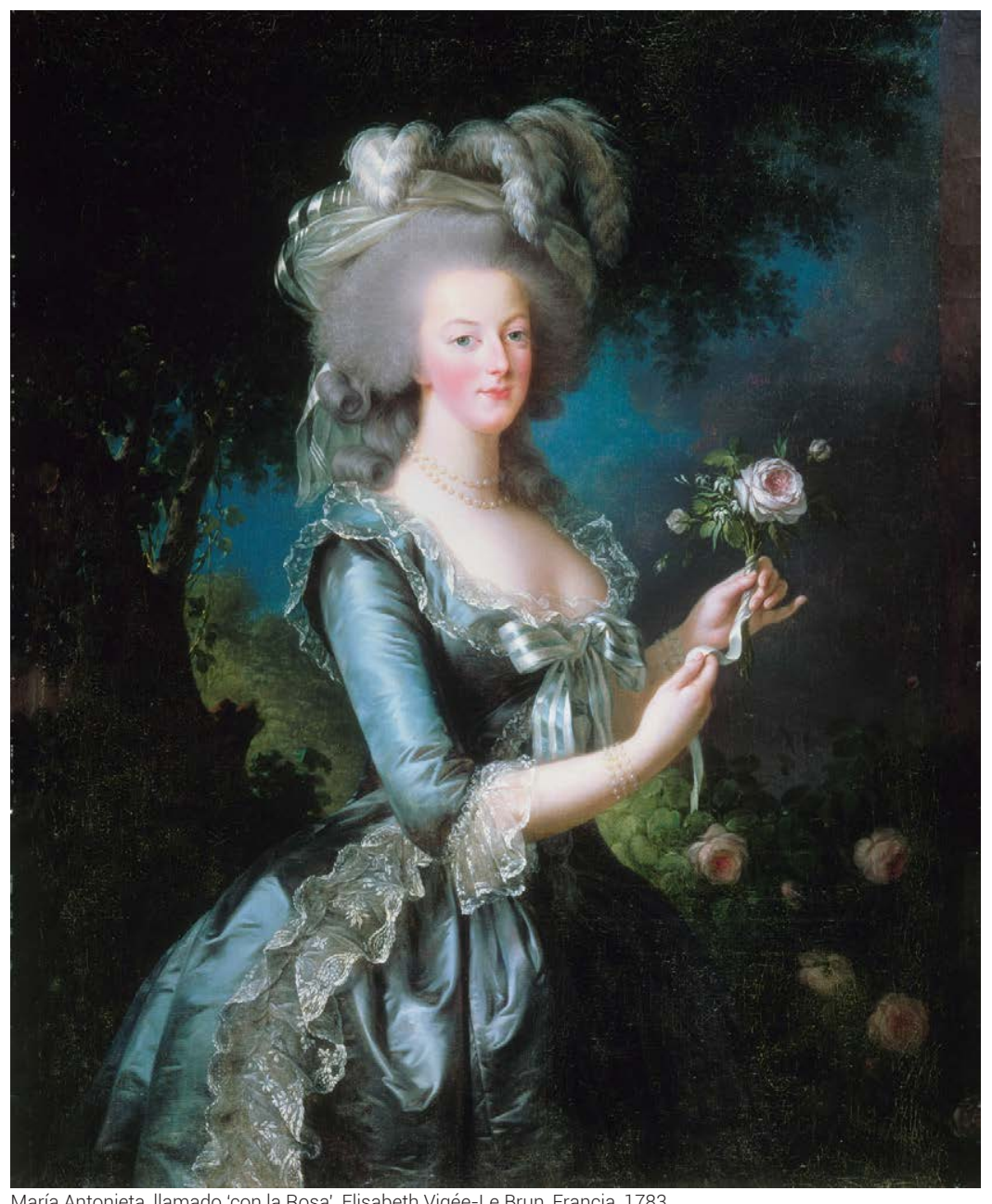

En el cuerpo humano, la película de suciedad sobre la piel que se puede apreciar en los siglos XVI y XVIII como un barniz protector supone en realidad un estorbo que impide los intercambios naturales entre el organismo y el medio ambiente. Desde mediados del siglo XVIII los médicos recomiendan lavarse con frecuencia el rostro, las manos y los pies, y aun 'de vez en cuando'162 el cuerpo entero.

Sin duda estas afirmaciones promueven, todavía, una limpieza corporal muy prudente. Si en el siglo XVI la ocultación del cuerpo sirve para evitar que el agua penetre a la vez que cumple con las normas de civilidad que dicta la iglesia, a partir del siglo XVIII la creencia sobre la importancia de dejar respirar a la piel también implica una transformación respecto a la percepción que se tiene del cuerpo física y moralmente. Desde el punto de vista físico se modifica la manera de vestir, que ahora es más ligera respecto al período anterior, como indicio de la necesidad que existe de mostrar cada vez más el cuerpo. Desde el punto de vista moral la limpieza de la piel a través de la circulación del aire da un nuevo significado a la palabra 'impuro', que pasa de tener un sentido moral -tacha en el alma- a convertirse en una característica del ser social -piel sucia-.

La aparición de la higiene En cualquier caso, esta nueva relación científica entre salud y limpieza que de alguna manera tiene sus antecedentes en los tratados medievales, favorece la aparición de un concepto hasta ahora inédito y que se desarrolla como fenómeno social en el siglo XIX, la higiene ${ }^{163}$

Los olores del Yo A la vez que se conoce la función protectora de la epidermis y el cuerpo se entiende como un organismo cerrado en sí mismo, con sus propios límites corporales, crece la intolerancia contra las excreciones y los aromas del otro ${ }^{164}$. En la misma medida en que los olores de Yo ${ }^{165}$ empiezan a definirse y a percibirse, los olores del No-Yo son sentidos como una amenaza y algo repulsivo. 


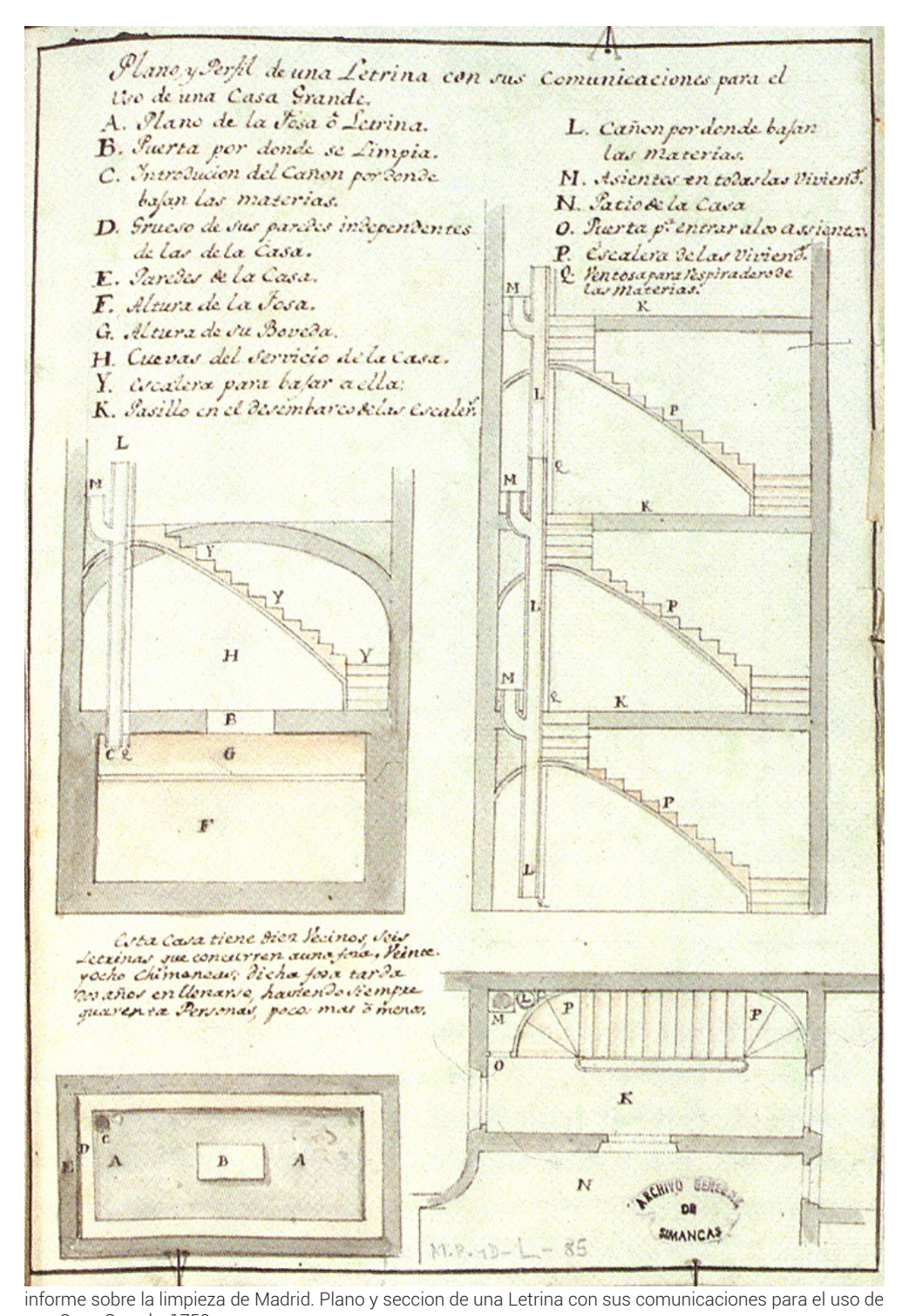

informe sobre la limpieza de
La nueva sensibilidad El ser humano medieval y el de la temprana Edad Moderna flota olfativa aún como un cuerpo más en un mar de miasmas conectado con el universo, y no puede olerse a sí mismo, conociendo tan solo el olor de pocilga colectivo. Sin embargo, a partir del desarrollo de una conciencia de su propia autonomía e individualidad, se hace más sensible y deja de soportar el olor de otras personas. Desde entonces los olores ajenos se perciben como una intrusión corporal, como una penetración en una esfera individual y cerrada que antes no existía ${ }^{166}$. No es que aumenten las molestias olfativas objetivas, sino que los niveles de tolerancia disminuyen.

Es precisamente la creciente sensibilidad contra el olor de la mierda el resultado del desarrollo del sujeto moderno ${ }^{167}$. Si entre los siglos XVI y XVII la eliminación del desperdicio participa en el lenguaje y en la ciudad de la gran experiencia de la vista168 169, desde mediados del siglo XVIII, y hasta finales del XIX, es el turno de la revolución de la percepción olfativa, que dirige su atención contra las heces ${ }^{170}$ : lo bello no huele ${ }^{171}$.

Mientras que el aspecto visual de las ciudades queda 'resuelto' con la domesticación del desperdicio tras el Edicto de 1539, respecto a la percepción olfativa el dispositivo de retrete conectado a una fosa séptica o pozo negro deja mucho que desear debido a las emanaciones fétidas que este sistema provoca.

La prohibición de arrojar por las ventanas, repetida insistentemente desde el siglo XII, y más seriamente desde el Edicto de 1539, para resolver el aspecto visual de las ciudades, es constantemente violada.

Teóricamente todo inmueble construido durante el siglo XVIII está dotado al menos de dos retretes: uno en la planta baja o cerca de la escalera y el otro en el último piso habitable ${ }^{172}$. Los asientos, a menudo, no tienen tapas. Se fabrican de hierro colado y de loza, comunicándose con una cañería de plomo conectada a una fosa séptica o a un pozo negro, con unas emanaciones fétidas insoportables en la sensibilidad del siglo XVIII. 

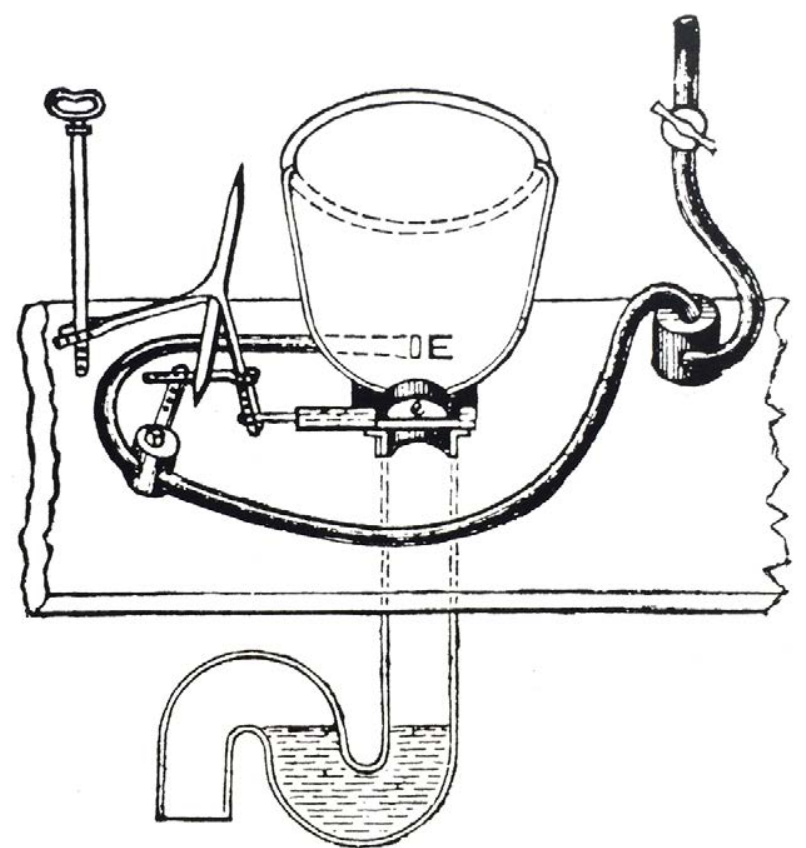

Retrete de cummings, 1775.
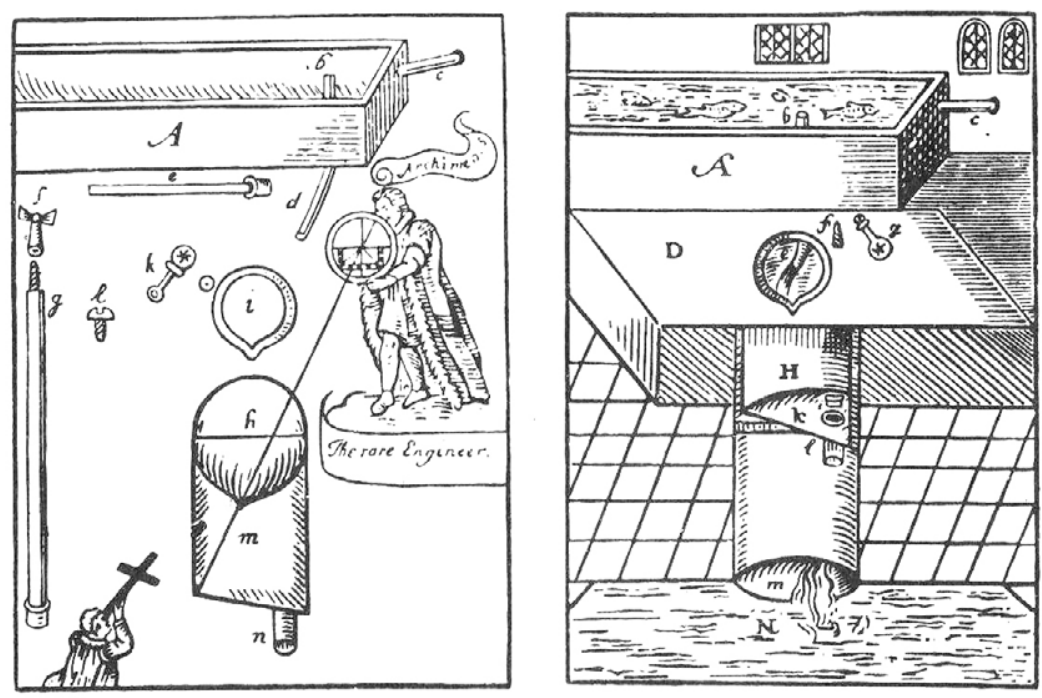

Retrete de Don Ajax: (izda) Este es el retrete de Don Ayax, todo por separado, para que el obrero vea lo que tiene que hacer. (Dcha.)... el mismo, en conjunto, para que el obrero vea si está bien.
El primer retrete moderno Tiene que aparecer en Inglaterra un invento como el ideado por el relojero Alexander Cummings en $1775^{173}$, el primer retrete moderno de válvula- valve-closet- con sifón hidráulico ${ }^{174}$, para que la tecnología se introduzca en el espacio doméstico ${ }^{175}$ e inicie un camino que permita realizar las funciones de eliminación en el interior del hogar con comodidad y, sobre todo, sin olor.

Ciento setenta y nueve años antes, el poeta y escritor Sir John Harrington describe en $1596^{176}$ un retrete de agua corriente para su obra La Metamorfosis de Ajax, una sátira contra las cloacas. El invento, a pesar de tener todas las características del retrete de válvula, cae en el olvido por la falta de tecnología para construirlo.

Gracias a Cummings el problema de la emanaciones mefíticas procedentes de los desagües comienza a estar resuelto con la incorporación del cierre hidráulico, un codo en el que siempre queda retenida una pequeña cantidad de agua que se renueva en cada uso y que incomunica la alcantarilla, aunque la válvula que él propone todavía es muy mejorable, ya que se ensucia constantemente. 

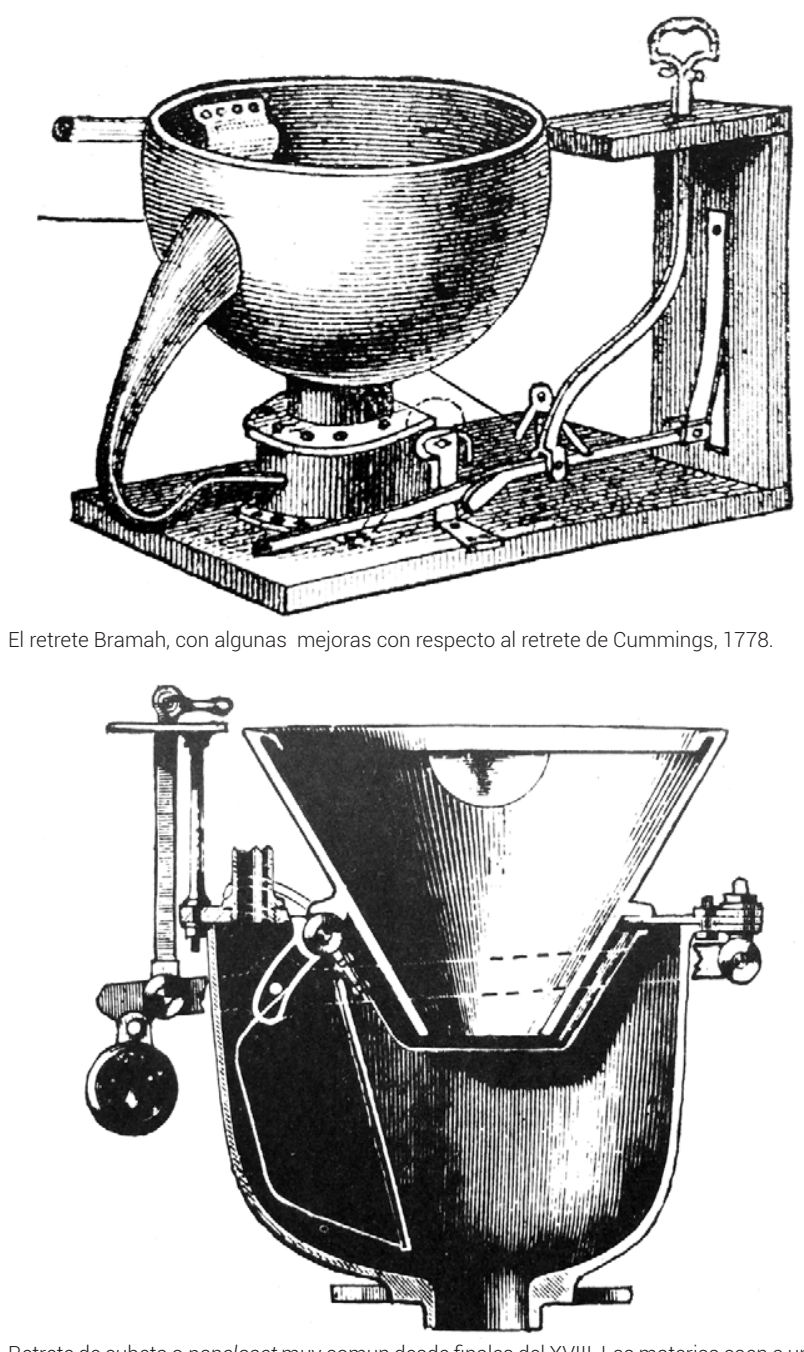

Retrete de cubeta o pancloset muy comun desde finales del XVIII. Las matere.
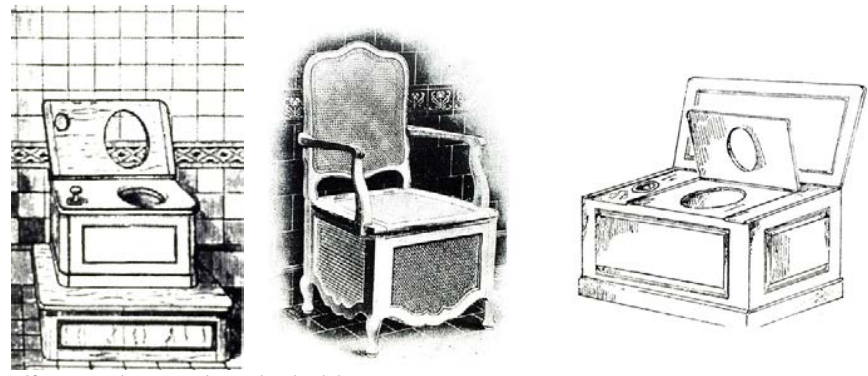

Tres años más tarde el ebanista y cerrajero Joseph Bramah perfecciona el modelo de Cummings incorporándole una válvula a manivela -cadena- y en 1778 patenta y comercializa el primer retrete con cierre hidráulico que impide que los olores del pozo negro invadan la habitación y que se convertiría en el retrete estándar de los siguientes cien años. Un tercer inventor, Thomas Crapper, mejora los componentes del inodoro ${ }^{177}$.

Desde el punto de vista de la tecnología, la mejor invención es el sifón. Se puede decir que gracias a él los retretes, ahora en teoría sin escapes de malos olores, hasta entonces situados en el exterior de la vivienda, empiezan a disponerse cerca de las habitaciones, como ocurre con la sala del tocador. A pesar de ello, muchas veces el conservadurismo de los ricos y la disponibilidad de servicio doméstico impide adoptar nuevas tecnologías como la fontanería, optándose por el orinal como medio para realizar las funciones de eliminación ${ }^{178}$.

En cualquier caso, inventos tecnológicos como el de Cummings ponen de manifiesto cómo el olor no solo se convierte en algo innombrable sino que también tiene que ser eliminado, relacionándose todo ello con el proceso de individualización del desperdicio y su incorporación a la esfera de lo privado ${ }^{179}$.

El hôtel francés como La primeratipología residencial que recoge estos adelantos técnicos es ámbito de innovación el lujoso Hotel de la aristocracia de París, la capital pionera en materia de higiene en el siglo XVIII. Parecidos a los grandes hoteles del siglo anterior, los hoteles del segundo tercio del siglo XVIII se caracterizan porque en ellos se encuentran muchas de las transformaciones de las relaciones individuales de la época. La verdadera novedad consiste en permitir una mayor intimidad personal que permite por primera vez, en relación con los nuevos ideales de individualidad y sensibilidad olfativa, la privatización del acto de defecar. 


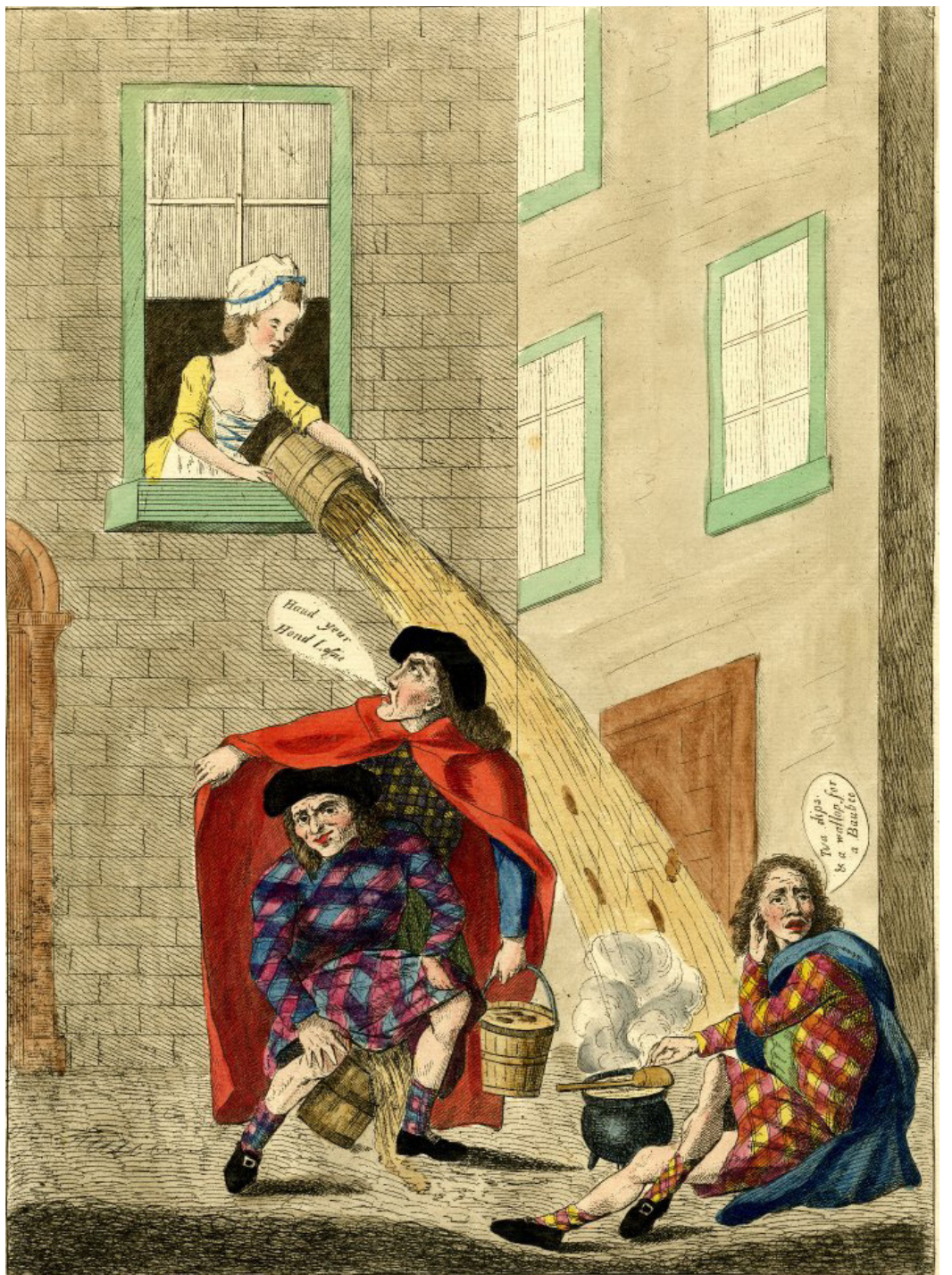

THEE FLOWERS of EIDINBURGH,

Ii dunna hen what Ican de

Gardy Loo, 1781

The flowers of Edinburg, Gardy Loo, 1781.

Than set ye doen so cure ye ter
El cuarto excusado De tal privatización parece que nace el 'cuarto excusado'180. Los lugares a la inglesa o lieux à l'anglaise, como llaman los franceses a estos nuevos espacios privados, transforman la utilización de la silla agujereada o sillico, instalándose un lugar fijo y cerrado para las funciones fisiológicas naturales que gracias a la nueva tecnología está exento de olores.

A consecuencia de las nuevas ideas médicas acerca de las impurezas que bloquean la piel, limpiar de manera escrupulosa los excrementos del cuerpo se convierte en una práctica que es específica de la ciudad y en particular de la clase alta que desde el siglo XVIII utiliza papel desechable para limpiarse el ano ${ }^{181}$.

El cuarto de aseo anuncia una nueva limpieza local, sin duda, pero escapa a la mirada y hace insuficiente el cuidado de la ropa. Se esboza un aseo íntimo, cuya aparición favorece la creación de un espacio más retirado.

La reaparición del baño La presencia en estos lugares de ciertos objetos precisos como e pero de agua fría bidé o las palanganas, y los jarros de estaño o de loza, conduce a pensar que las nuevas aportaciones teóricas que hace la medicina sobre la piel comienzan a surtir efecto, al menos entre la clase alta de la sociedad. Este hecho, junto a la progresiva desaparición de los temores a las pestes y a otras enfermedades, produce, desde mediados del siglo XVIII'182, un cambio de paradigma respecto a la noción del agua, a la que se deja de tener miedo.

Para algunos, la muda de ropa puede no ser ya el único acto relativo a los cuidados de la piel. Las nuevas investigaciones científicas durante este periodo revelan las propiedades químicas del agua, provocando un cambio de estatuto del baño de inmersión, que reaparece, cas después de doscientos años, aunque frío y exclusivamente con fines terapeuticos. 

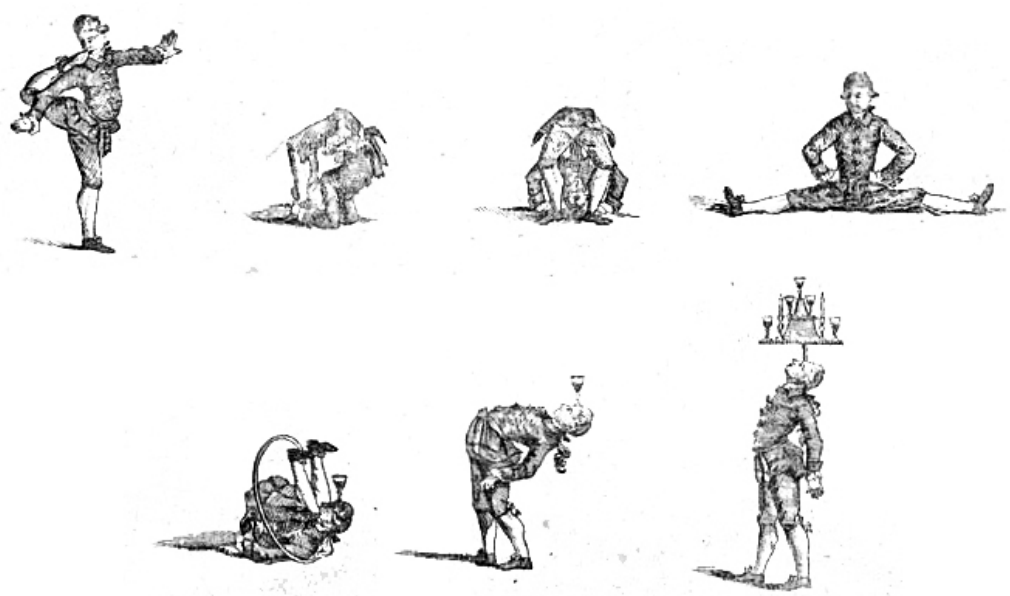

Acróbatas, J. B. Basedow, 1774 En 1770 no
corporal.

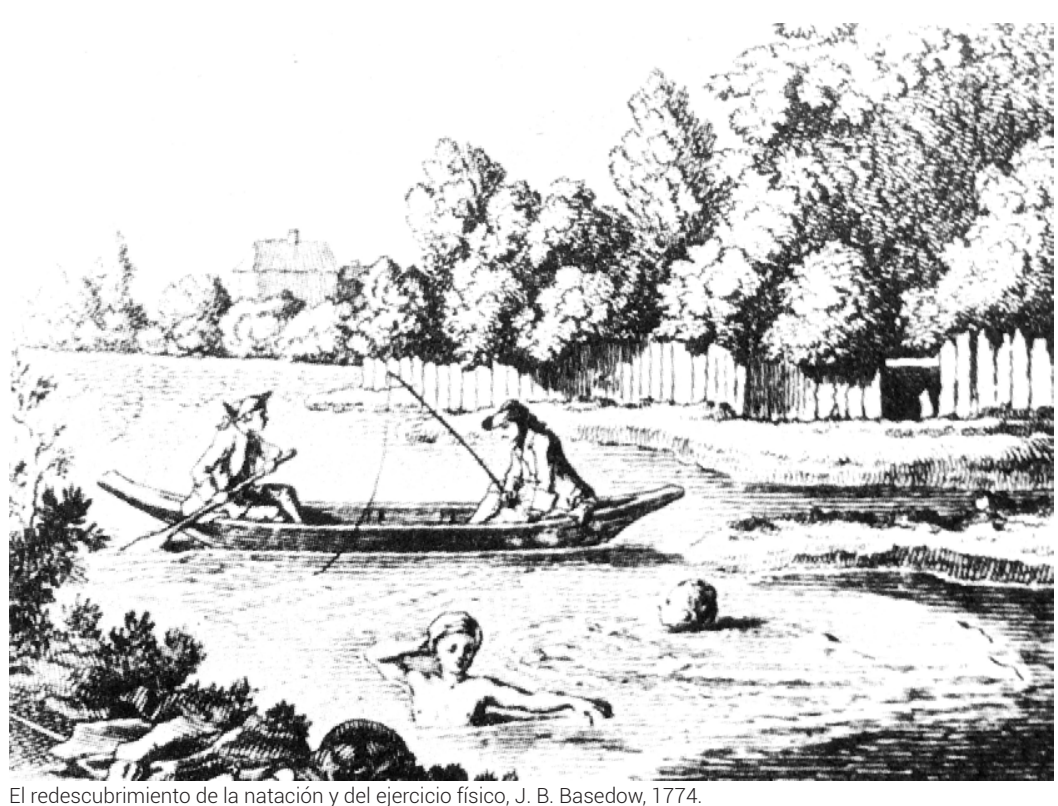

Algunos médicos, como el escocés James Currie, recomiendan abluciones y baños con agua fría para tratar las fiebres y las enfermedades contagiosas. La temperatura del líquido se vuelve determinante: el baño frío, en oposición al baño de calor por la condensación de los sólidos, da energía y fortalece ${ }^{183}$. La referencia al baño frío comienza a tener, por primera vez, una calidad explícitamente higiénica, menos porque deja limpio que porque pone fuerte: una nueva moralidad que se relaciona con lo físico desplazando los valores respecto a la época anterior ${ }^{184}$

Mientras que tradicionalmente el mantenimiento de la salud se entiende como la conservación de un bien amenazado, desde finales del siglo XVIII, con la aparición de la ciencia médica, se introduce la posibilidad de mejorar ese bien con la promesa de un futuro capaz de cambiar el cuerpo.

El retorno a la naturaleza La reaparición del agua, que coincide con la revolución médica, se refuerza cuando a finales del siglo XVIII aparece un movimiento de vital importancia que afecta a la recuperación del cuerpo humano. Es la proclamación del retorno a la naturaleza del filósofo y pensador francés Rousseau la que determina, en gran parte, los comportamientos de la época. Desde entonces los instintos primarios buscan ser reconquistados, pues precisamente en esta época el ser humano primitivo, el noble salvaje, es descubierto y convertido en tema de filiación romántica ${ }^{185}$.

No solo hay que conseguir una relación de armonioso equilibrio entre los seres humanos, sino que también hay que mantener en cada individuo el equilibrio entre mente y cuerpo. Así, los primeros esfuerzos pedagógicos prácticos para conseguir este objetivo aparecen en las últimas décadas del siglo XVIII cuando la gimnasia, las carreras, el salto y la natación se convierten en elementos necesarios en la educación ${ }^{186}$. En este contexto, reaparece el agua como medio fundamental de limpieza. El retorno a la naturaleza de Rousseau aparece en las vigorizantes abluciones con agua fría. 


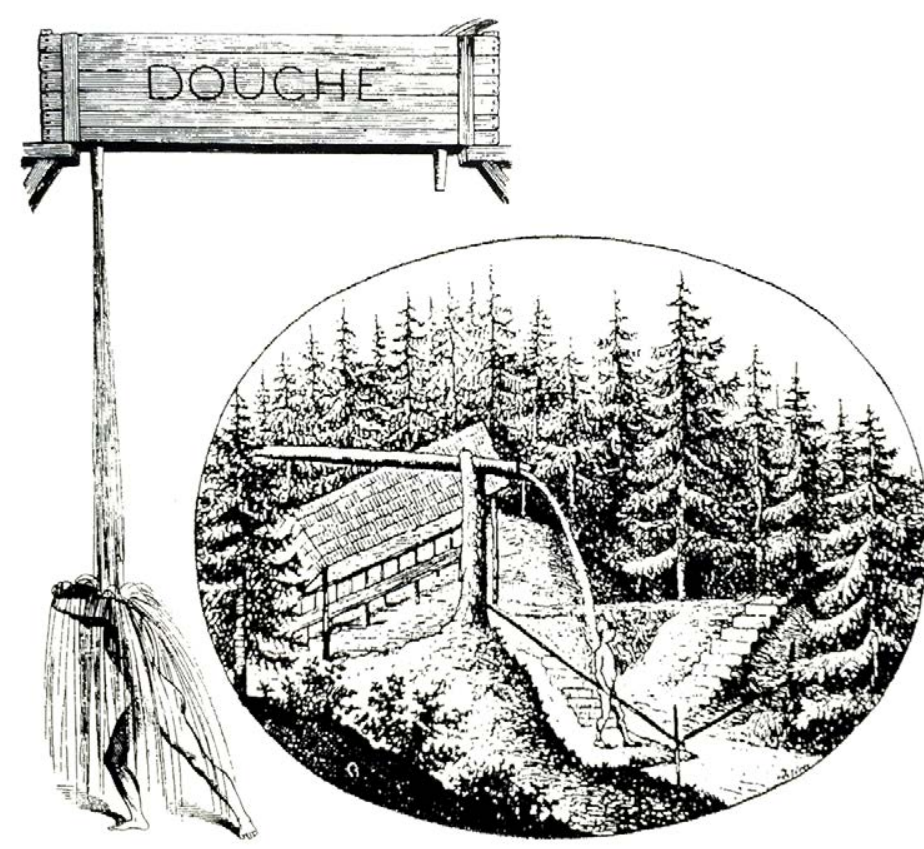

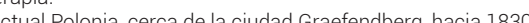
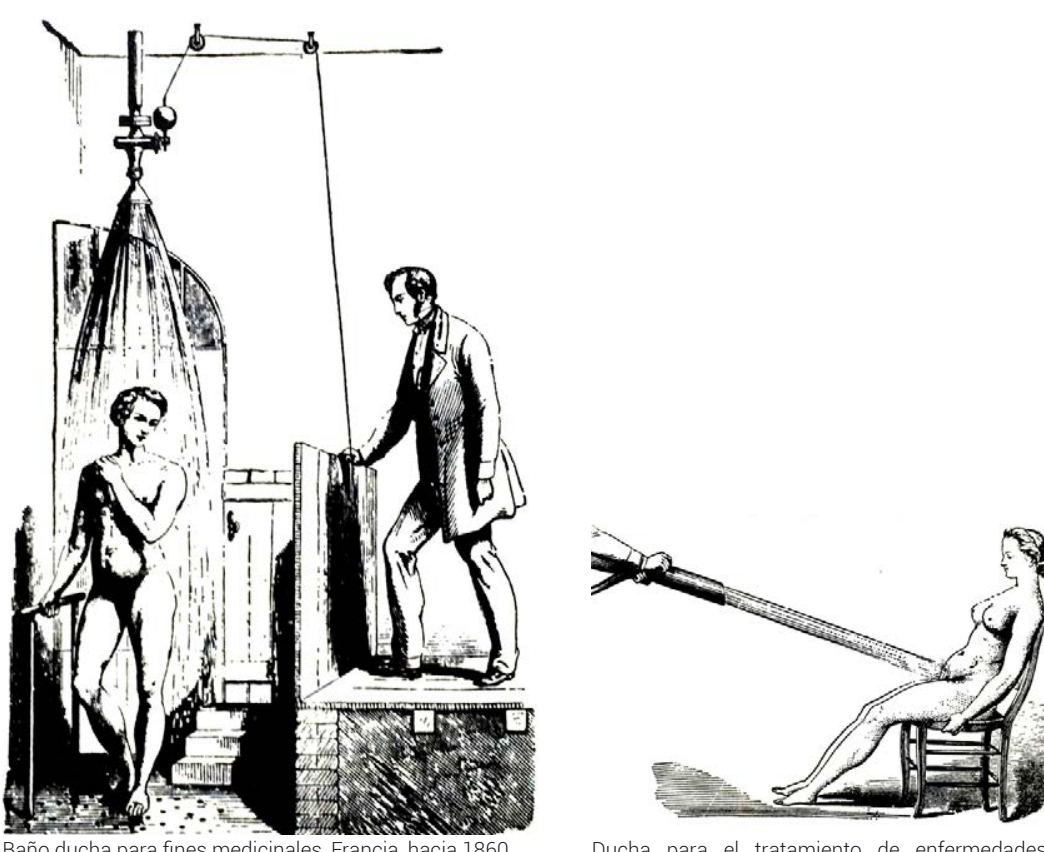

Ducha para el tratamiento de
abdominales, Francia, hacia 1870 .
En cualquier caso, y a pesar de los avances tanto médicos como filosóficos respecto al cuerpo, parece que la utilización del agua en la limpieza corporal a finales del siglo XVIII todavía es un tema algo confuso y reservado a un público extremadamente limitado. No es hasta las primeras décadas del siglo XIX cuando este ideal se difunde entre la población, convirtiéndose en una práctica común.

Las terapias hídricas como Es posible que las exclusivas terapias hídricas que aparecen en el medio para fortalecer el este de Europa ${ }^{187}$, alejadas de las ciudades, entre los años 1830 y

cuerpo 1850, y en los establecimientos públicos de algunas ciudades ${ }^{188}$, sean los primeros lugares donde se hace un uso del agua fría con fines exclusivamente terapéuticos. Consisten en tratamientos corporales que utilizan el chorro de agua a presión, generalmente fría, que aplicados al cuerpo, aspiran a su robustecimiento ${ }^{189}$. Estas terapias combinan de un modo severo los principios de la medicina como ciencia terapéutica con la vida en contacto con lo natural, abarcando, después de mucho tiempo, al organismo en su totalidad ${ }^{190}$

En este marco primitivo, la educación natural recupera las vigorizantes abluciones con agua fría y, junto al control del movimiento corporal a través de la gimnasia, la danza, la esgrima y la natación, busca un equilibro entre la mente y el cuerpo parecido a la máxima griega mens sana in corpore sano

Frente al cuidado de la apariencia y el espectáculo de la aristocracia en los siglos XVII y XVIII, los establecimientos hidropáticos impulsan y promueven una transformación que, legitimada por la ciencia y en su relación con la naturaleza, se fundamenta en la salud y en la fortaleza del cuerpo. Desde entonces estar limpio es proteger y fortalecer el cuerpo, y la limpieza es precisamente la que garantiza la buena marcha de las funciones.

Para que la piel respire es imprescindible el lavado frecuente: ya no basta con mudarse de ropa interior, hay que liberar los poros, mediante agua fría, de la misma manera que lo hace la cultura griega para dar un mayor vigor y firmeza al cuerpo evitando disfrazar con perfumes fuertes el olor del sudor. 

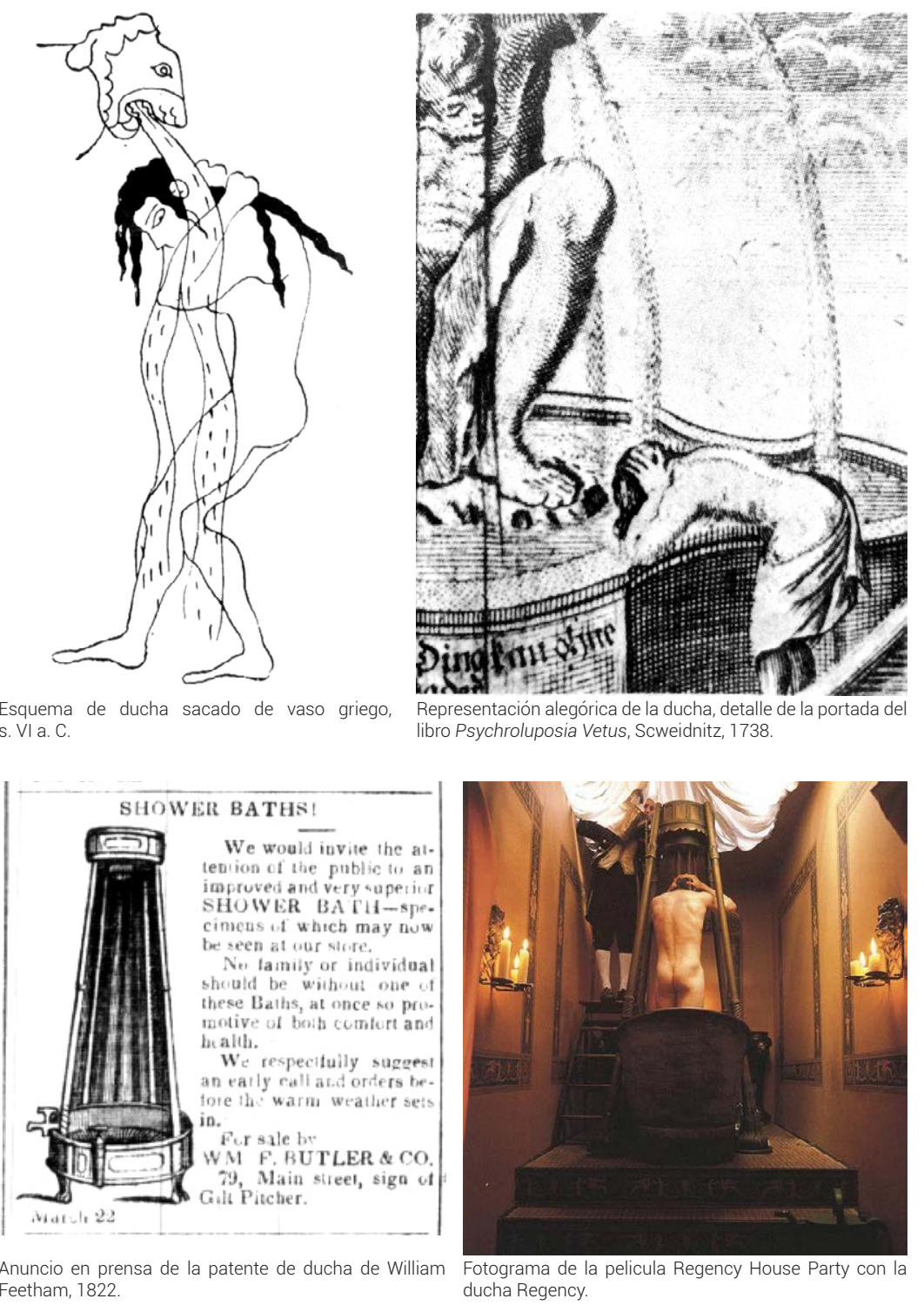

La ducha terapéutica A mediados del XIX el movimiento de retorno a la naturaleza acelera la recuperación e introducción de un elemento de las primeras civilizaciones que, hasta la actualidad, va a constituir la expresión más genuina de la higiene: la ducha.

Sin embargo, durante estos primeros años del siglo XIX, la ducha, lejos de ser una práctica higiénica cotidiana, prioriza su uso terapéutico ${ }^{191}$ Así lo demuestra la Gran Enciclopedia Francesa, que desde 1755 define a la ducha o douche como terme de chirurgie, un término quirúrgico/término de cirugía ${ }^{192}$. Hasta los trabajos del químico Louis Pasteur, en la segunda mitad del siglo XIX, el agua no cobra su verdadero valor 'limpiador'.

Lejos de las montañas, en las ciudades, en el espacio doméstico de las clases altas se busca reproducir la misma idea rousseauniana de contacto con la naturaleza a través de la instalación de artefactos que simulan una ducha al aire libre. Antes de que exista un suministro regular de agua al que puedan estar conectados los aparatos permanentemente, los primeros modelos son portátiles y toman como referencia la bañera tipo, a la que añaden un depósito en la parte superior que se llena generalmente o bien a mano o bien mediante una compacta bomba manual y que descarga el agua cuando se tira de una cadena o se acciona una llave, obteniéndose así la presión necesaria. Son los casos de la primera ducha de este tipo, inventada por William Feetham en el año 1767, y su sucesora del año 1810, la Regency Shower. 

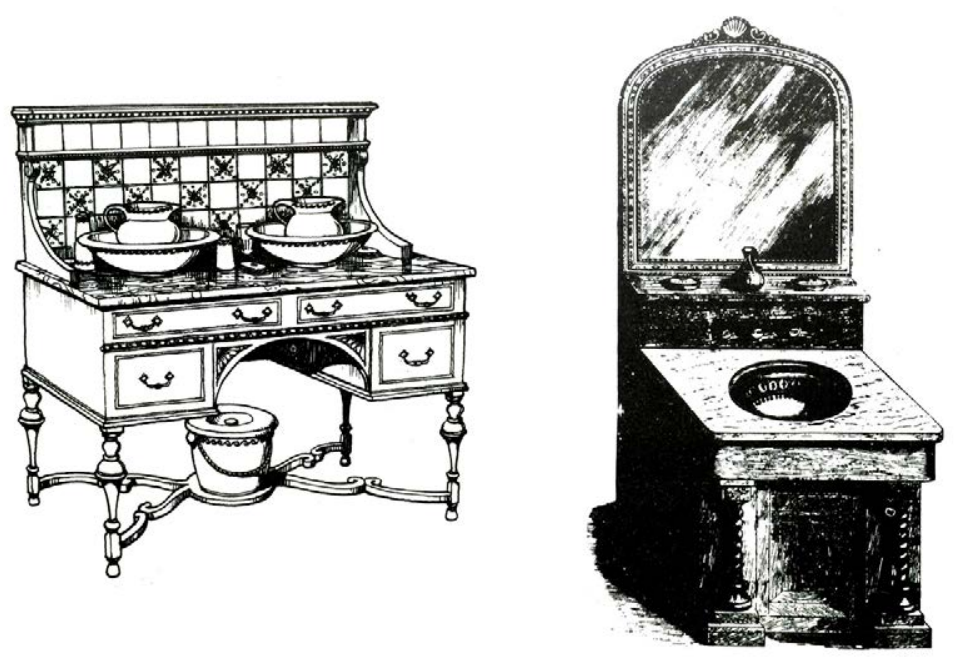

Distintos modelos de lavabo: (izda.) hacia 1880 y (dcha.) 1882.

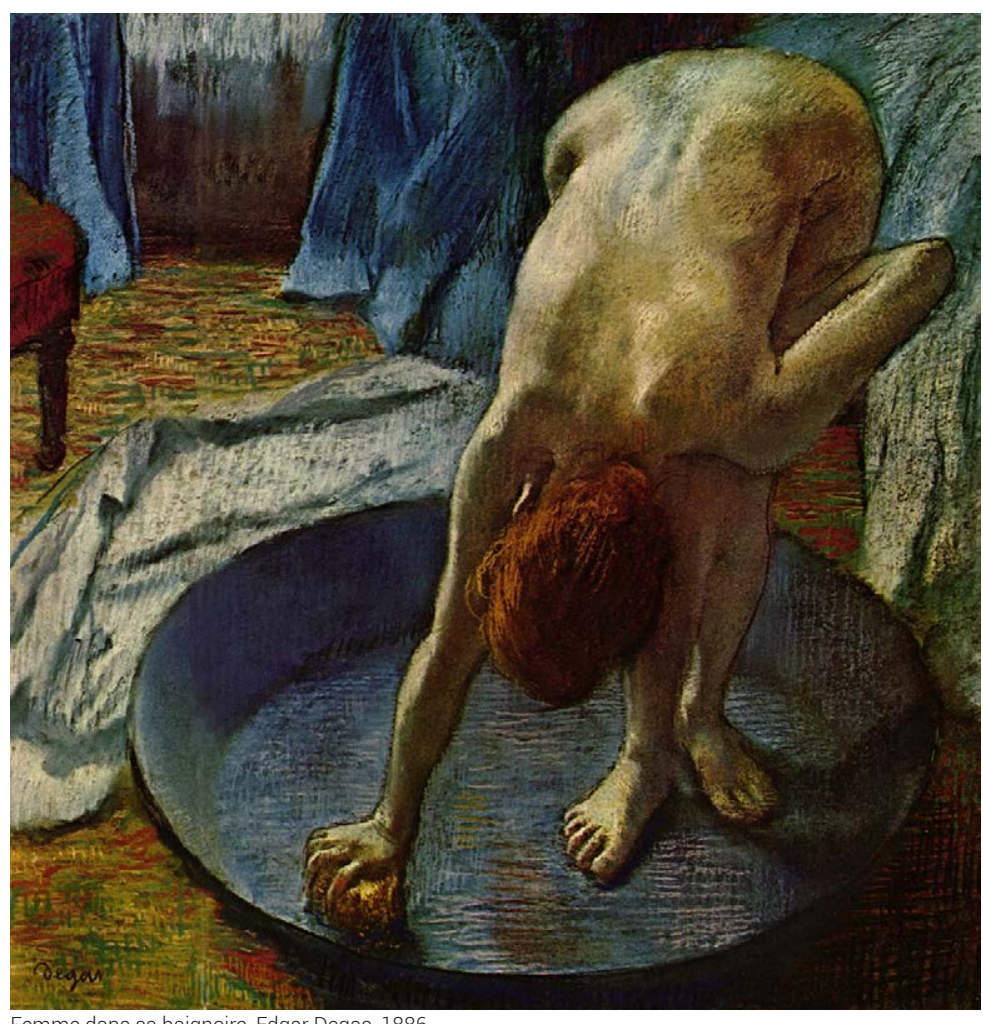

Femme dans sa baignoire, Edgar Degas, 1886
Junto a la ducha, en la vivienda burguesa de principios del siglo XIX también se disponen, de una manera deslocalizada, otros elementos para la realización de abluciones eventuales, como bañeras, palanganas y jarros de loza ${ }^{193}$. Estas actividades ocurren generalmente en la cocina, junto al fuego, aunque, de modo general puede decirse que no hay destinado un lugar fijo ${ }^{194}$, salvo si se cuenta con servicio doméstico, en cuyo caso se realizan siempre en el dormitorio y frente a la chimenea, hasta donde se hacen trasladar las bañeras portátiles.

La evolución del lavabo Un caso diferente es el del lavabo, el otro elemento 'sanitario' que facilita una limpieza parcial y que ya desde finales del siglo XVIII se encuentra instalado en el rincón o contra una pared del dormitorio, sin conexiones a una red. Como respuesta a los requisitos de la nueva higiene, en el siglo XIX se produce un aumento de este aparato para incorporar el cuenco y las jarras. Después de transformarse en un pequeño armario de forma circular según la moda, en la década de 1830 aparecen los aguamaniles en forma de cómodas o mesas.

La divulgación de los ideales higiénicos, que exigen una limpieza total del cuerpo, es responsable de que, durante estos primeros años del siglo XIX, se busque cada vez más la intimidad al realizar estas prácticas; la habitación privada se configura como el lugar idóneo para ellas, incluso para las viviendas más modestas.

Sin duda, los utensilios portátiles para la limpieza corporal se convierten lentamente en los receptores de las nuevas exigencias higiénicas. La revolución industrial aporta, de momento, un mero respaldo comercial a su creciente demanda, con mejores materiales y una producción, aunque todavía artesanal, más organizada y de mayor volumen que posibilita poner al alcance de mucha más gente este menaje. La incipiente higiene comienza a tener presencia aunque todavía un poco limitada, allí donde quizás apenas se conoce la limpieza corporal. 

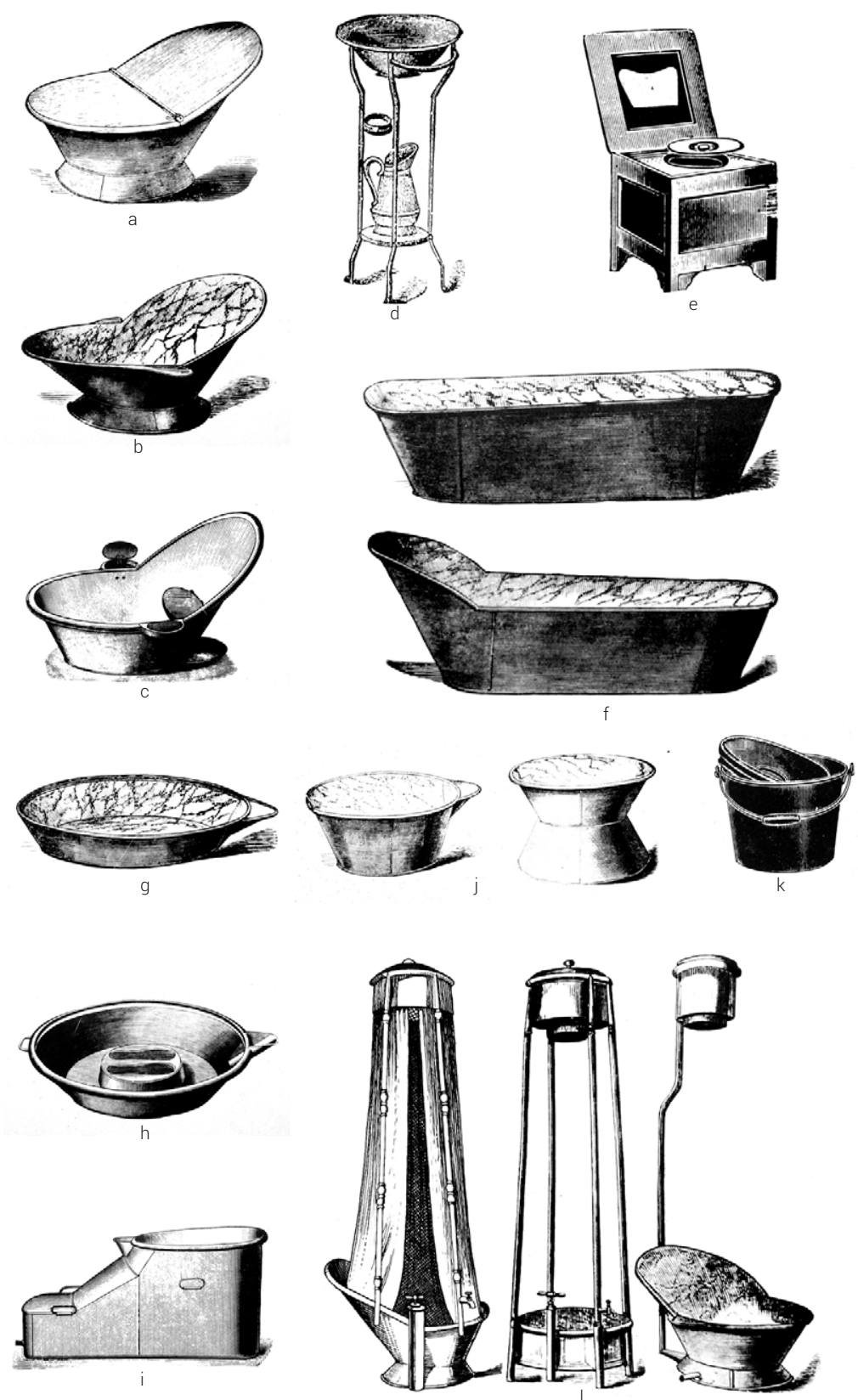
asiento, (d) tripode para jofaina y aguamanili, (e) retrete, (f) baños de cadera, (g) baño de esponja, (h) baño de pies.
No solo es la predicación del médico la impulsora de la higiene sino también, en muchos casos y sobre todo, la publicidad de las patentes, que se pone en marcha a través de guías y catálogos donde se muestran muchos de los productos. Por ejemplo, la edición de 1794 de la Guía de Hepplewhite, además de ofrecer varios modelos de mesillas de 'aparadores para orinal', también da varios ejemplos de 'mesillas de noche' que esconden un asiento con un receptáculo en su interior ${ }^{195}$.

Los nuevos aparatos para la La Gran Exposición de 1851 celebrada en Londres en el Hyde Park es higiene el gran escaparate de soluciones de la amplia variedad de aparatos individuales que se llegan a fabricar ante la creciente demanda de higiene en una civilización industrial. Desde las formas más tradicionales, como el Baño de Esponja' ${ }^{196}$, el Baño Completo ${ }^{197}$, el Baño de Asiento ${ }^{198}$, el Baño de Cadera ${ }^{199}$, hasta las propuestas más sofisticados, como el Baño de Fuente ${ }^{200}$, el Baño de Zapatilla ${ }^{201}$ o incluso el Baño Portáti ${ }^{202}$, todas tienen cabida en un espacio, aunque muchos de estos aparatos se quedaron en prototipos por su falta de viabilidad económica y de demanda popular. 


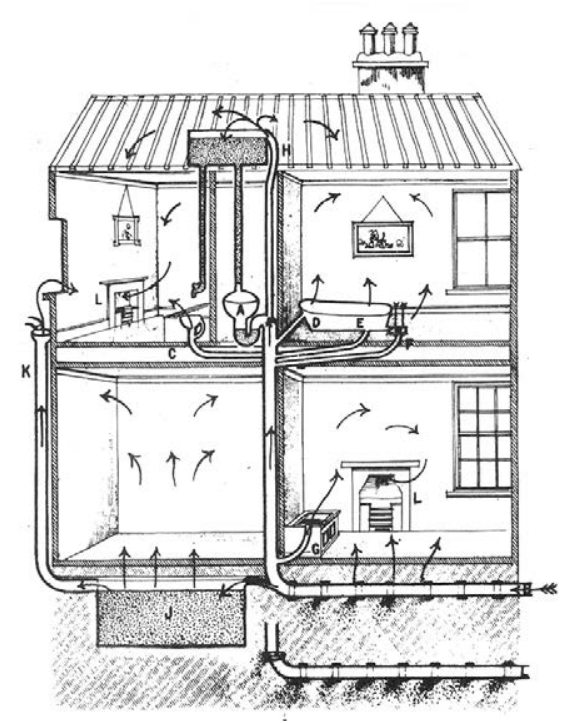

Sección de unavivienda, 1878: (A) W.C. enel centro dela casa, (B) saneamiento de la casa por debajo del suelo de una habitación, (C) tubo de desagüe de canal directo para los gases del sumidero. (D) tubería de desagüe del baño sin trampa y encajada en la tubería de aquas residuales, (E) tubo de desagüe del baño, sin trampa, encajado en la tubería de aguas residuales, (F) bandeja que lo recoge todo debajo de las llaves sin trampa, encajada en la tubería de aguas residuales, (G) fregadero de la cocina, sin trampa, encajado en la luberia de aguas resíduales, (H) cisterna o depósito del W.C. con desagüe en desagüe a la alcantarilla, (K) tubo de bajada que conduce el aire viciado del depósito contaminado por el gas del sumidero y que desemboca justamente debajo de una ventaja, (L) alcantarilla por debajo de la casa con las juntas cin del retrete con la alcantarilla horizontal: alcantarilla instaso de lubo vertical inclinación. (Dr. T. Pridgin Teale).
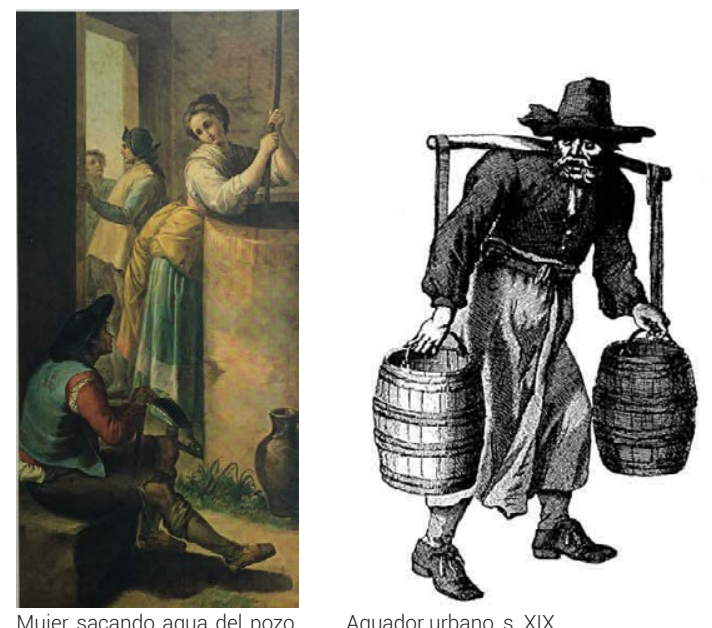

Mujer sacando agua del pozo,
Erancisco Bayeu, España, Aguador urbano, s. XIX Francisco
hacia 1876
La disponibilidad de agua A pesar de las transformaciones de la superficie de la ciudad en el en el espacio doméstico: el siglo XVIII, la realidad es que hacia 1800 las grandes urbes carecen tanque depósito todavía de suministro regular de agua. La disponibilidad de agua fría en el espacio doméstico, hasta la segunda mitad del siglo XIX, se realiza por distintos medios. Mientras que las clases menos pudientes transportan el agua a mano desde el pozo o la fuente pública hasta la vivienda, los más ricos disponen de un suministro irregular semanal a las casas por medio de tubos de plomo203 204 o bien mediante un depósito-tanque ${ }^{205}$, que previamente rellenan los sirvientes, situado bajo la cubierta y que luego, mediante una bomba de mano colocada en la cocina, distribuye el agua por toda la casa a través de un circuito interno de tuberías.

Los baños a domicilio Además de estas opciones, y hasta 1846, también es frecuente la existencia de aguadores ambulantes, una figura que tiene su origen al final de la Edad Media ${ }^{206}$. Circulan por las calles transportando los famosos 'baños a domicilio' a todas aquellas familias privilegiadas que solicitan sus servicios ${ }^{207}$

Sin embargo, estos aguadores no solo transportan agua sino que se encargan de llevar las bañeras de zinc a las casas que lo requieren. Se les llama 'baños a domicilio', frente a los baños fijos de los establecimientos públicos. La frecuencia del baño en la primera mitad del siglo XIX, y entre las clases más ricas, es una media de tres veces al año por cada parisino 208

203 WRIGHT, Lawrence. Op. cit. 188

A pesados facilite que pertirdad de disponer de este circuito doméstico cerrado a presión la que, junto a la existencia en el mercado de muebles cada vez más

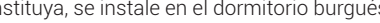
sus carros cargados de tinas de agua caliente, indicio de las instalaciones de suministro de aqua que están por venir. Los estuferos o bañeros de agua caliente constituyen un gremio con reglas muy claras por parte del monarca, entre las que destaca no anunciar por las calles que el baño esta listo antes de la salida de 


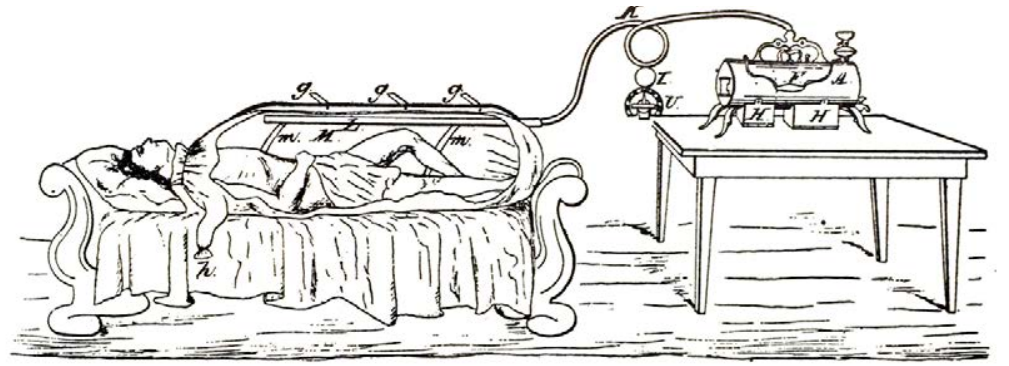

Aparato para baño de vapor, Estados Unidos, 1855

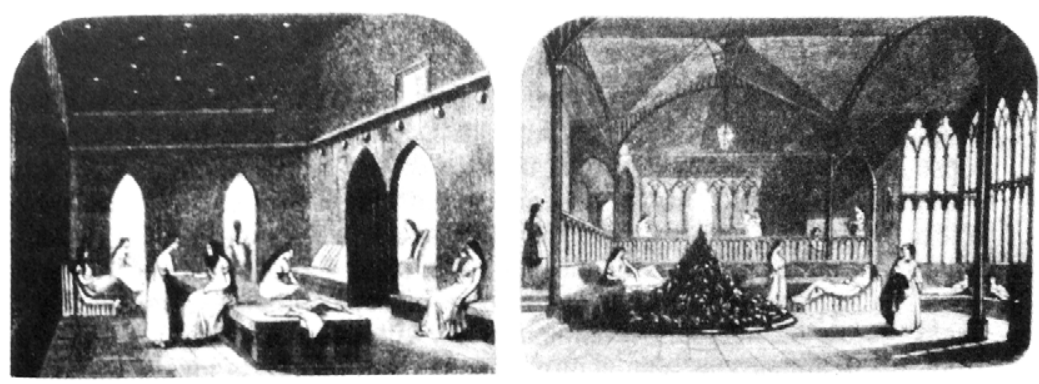

Primer baño turco en Irlanda: St. Ann's Hill Hydropathy Establishment, Cork, década de 1850.

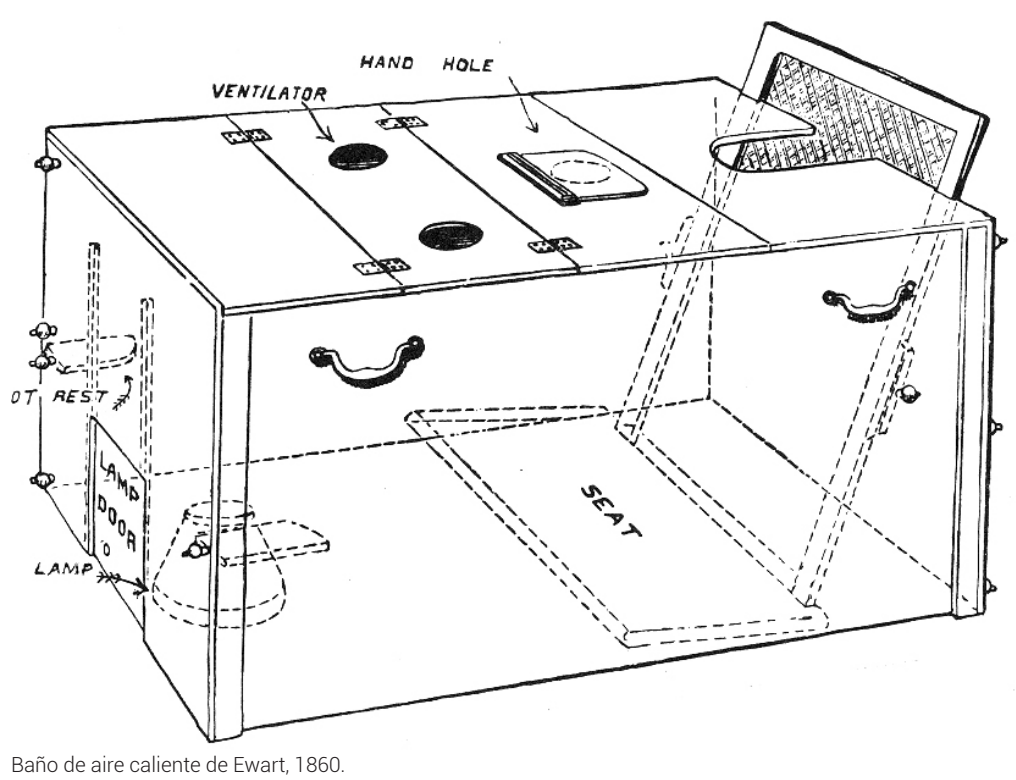

Los baños de vapor caseros La creciente importancia de la apariencia del cuerpo y su cuidado provoca que se busquen mecanismos alternativos de limpieza corporal previos a que la mecanización entre en el espacio doméstico. De esta manera, en los primeros años del siglo XIX, además de los baños de agua fría domésticos aparecen formas alternativas de limpieza en la vivienda que no requieren de la presencia del agua y que coexisten con ellas, como es el baño de vapor casero en cubículo, que desde 1832 busca recuperar las formas de regeneración clásica por excelencia ${ }^{209}$, el baño turco o Hamman en 1855, procedente de Oriente 210 , y el baño atmosférico de sol y aire en $1870^{211}$. Todas ellas son formas que lo que hacen es retrasar la implantación de las verdaderas formas higiénicas poco antes de 1880.

A través de todos estos mecanismos domésticos, el siglo XIX define gradualmente el concepto de la higiene. Sin embargo, es imposible que esta se popularice hasta que no aparezcan las redes de distribución de agua y de saneamiento. 


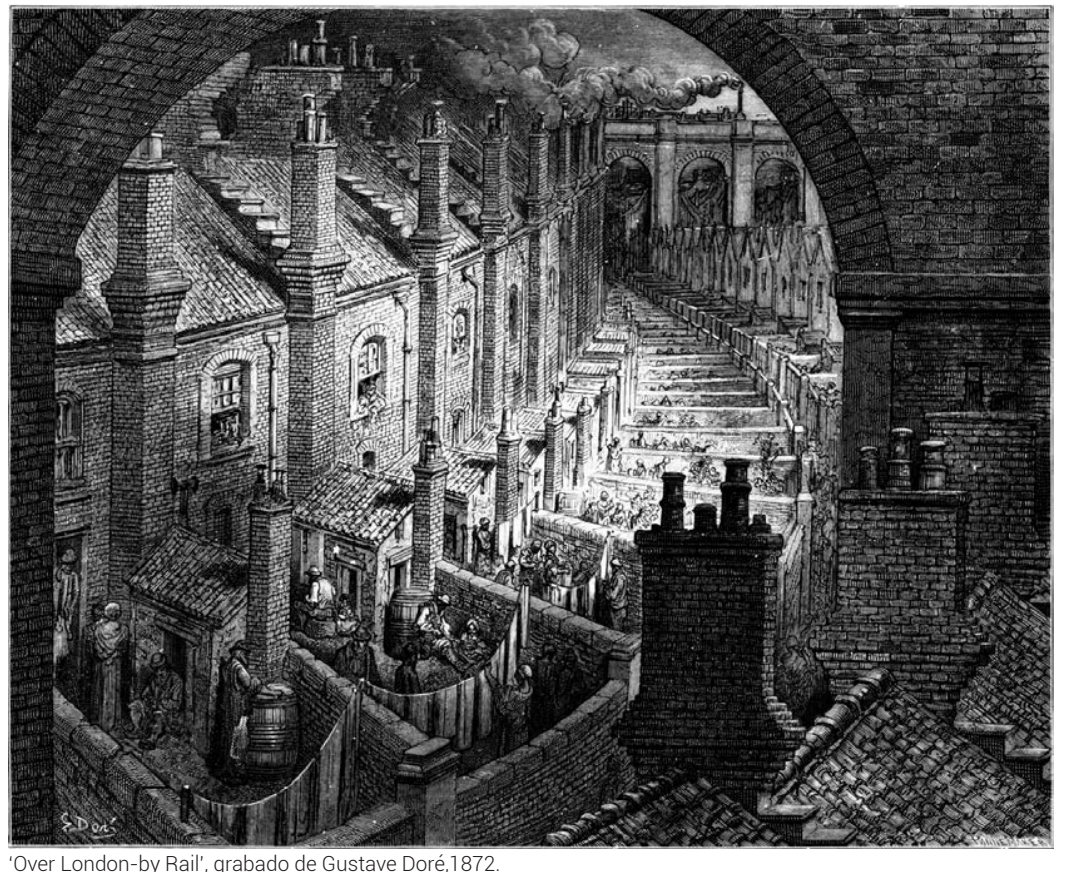

104

\section{PELIGROS DE MADRID.}

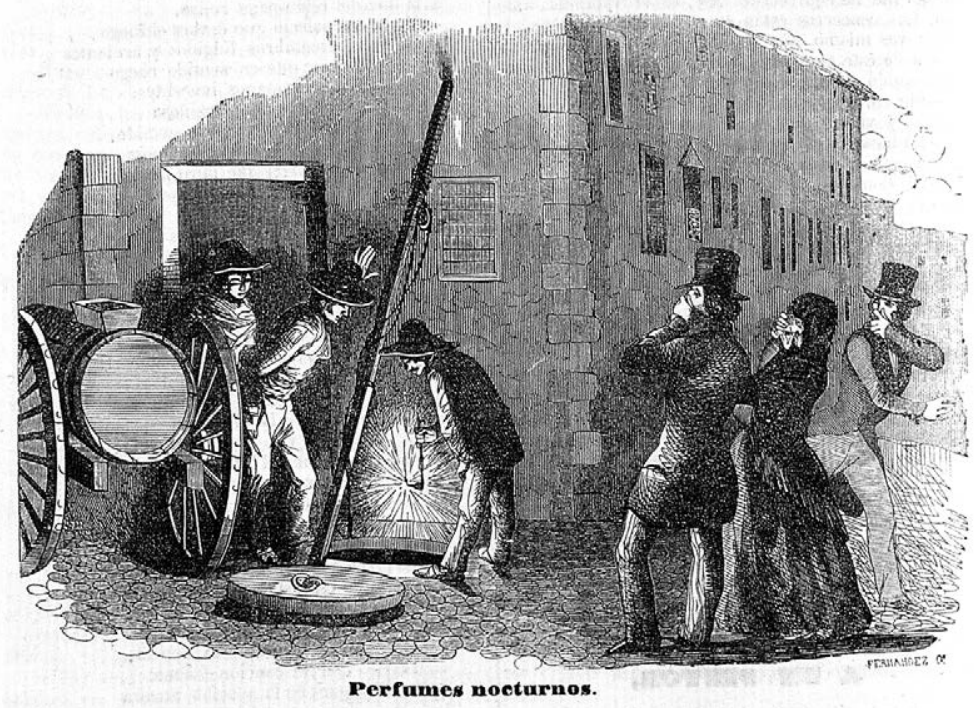

Limpieza de pozos en 'Peligros de Madrid', grabado 'Perfumes nocturnos. Semanario Pintoresco Español, 1847. a imagen de una parte de la población, la más rica 'disfrutando' de la nueva higiene y sus beneficios en la primera mitad del siglo XIX contrasta sin duda con otra realidad de las ciudades en la misma época. Parece que de todas las transformaciones que suscita el progreso técnico tras la Revolución Industrial, la que está vinculada a las condiciones del hábitat tiene una especial relevancia. El aumento de la población en las ciudades, como consecuencia de la emigración del campo, incide especialmente en los centros urbanos, que ven cómo una masa humana colmata sus barrios, sobre todo en los más pobres, poniendo de manifiesto la carencia de infraestructuras sanitarias necesarias en las ciudades.

Las casas obreras están construidas en dobles hileras sin ventilación ni saneamiento alguno. Cuentan con patios muy reducidos donde en un extremo se sitúa una fuente y en el otro un retrete compartido para veinte viviendas. Las zanjas de aguas sucias o pozos negros, frecuentes incluso en las casas más pudientes, se sitúan en el patio o en el interior del espacio doméstico, bajo la sala de estar ${ }^{212}$

Los hombres nocturnos y la El vaciado periódico del contenido de estos espacios lo realizan eliminación del desperdicio mediante una bomba, los 'hombres nocturnos'213 sucesores de los gongfermors medievales ${ }^{214}$. Ellos transportan esta materia, por medio de carros-máquina con toneles de forma troncocónica ${ }^{215}$, a las afueras de la ciudad, como por ejemplo en fosas al aire libre como la de Montfaucon de París ${ }^{216}$, que permanecen abandonadas durante muchos años.

Con bastante frecuencia una parte de los líquidos se filtra al suelo y se mezcla o bien en los pozos o bien en el río más próximo, contaminando las aguas, que dejan de ser adecuadas para su uso doméstico, lo que no impide que se utilicen²17. A medida que avanza el siglo, con los descubrimientos en materia higienista, la policía sanitaria plantea hacer desaparecer estos pútridos lugares.
WRIGHT, Lawrence. Op.cit. 184 comienza a las once de la noche en verano, hasta las seis de la mañana, y desde las diez hasta las siete en invierno (GUERRAND, Roger-Henri. Op.cit. 100). 215 En París cada carro contiene 32 toneles de 86 centímetros de alto, 40 centímetros en la base y 24 centímetros de diámetro en la boca (GUERRAND, Roger-

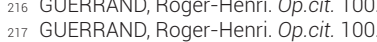


El excremento como bien Sin embargo, la puesta en práctica de esta decisión viene cargada productivo de polémica, sobre todo para el mundo agrario. La desaparición del excremento pone en peligro su valor productivo, que desde el tiempo de los romanos se utilizaba para abonar las tierras. El desecho es ahora un elemento fundamental para la economía de un país, una condición de vida y fuente de riqueza que algunos utopistas como Pierre Leroux confirman diciendo que su contenido en elementos reproductores es suficiente para atender las necesidades de consumo, progresivamente crecientes, de la sociedad ${ }^{218}$ Ciertamente el capitalismo saca provecho de todo ${ }^{219}$, a pesar de que, paradójicamente, la relación entre el vertedero y la rentabilización del desperdicio sea antinómica.

Como solución a este problema, que persiste hasta casi finales de siglo XIX, se busca la separación de los líquidos de los sólidos en los mismos lugares de producción ${ }^{220}$, a través de la fabricación de aparatos separadores como los expuestos en las Exposiciones Universales de 1855 y 1867. Estos aparatos retienen los sólidos y dejan correr los líquidos hacia la alcantarilla221 mediante el vaciado de materias líquidas directamente a la vía pública, atendiendo a una orden en París de $1891^{222}$. De este modo, el ideal higienista de asegurar tanto la salud pública como las necesidades económicas parece quedar 'garantizado'.

En cualquier caso, estas 'soluciones' al desperdicio, inscritas dentro de la urbanización e industrialización del mundo europeo, no pueden evitar la creación de las condiciones ambientales necesarias para la rápida propagación de enfermedades, pestes y epidemias. 


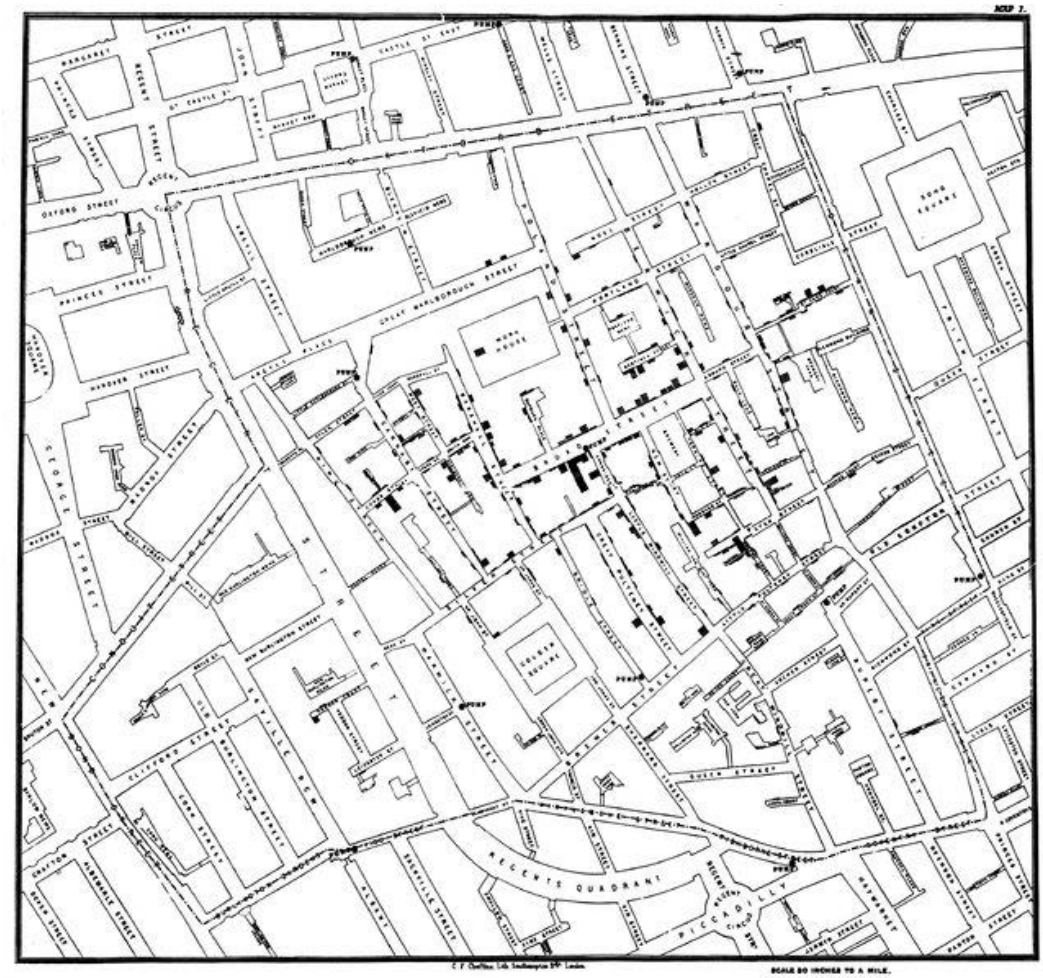

Plano original de John Snow mostrando la
Dibujado y litografiado por Charles Cheffins.

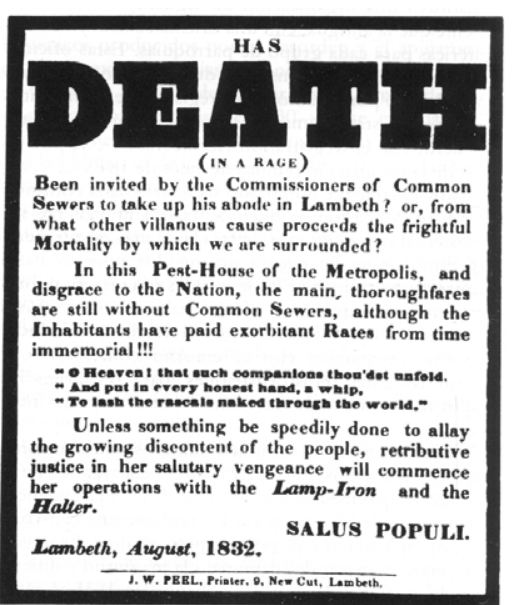

Denuncia pública aparecida en la prensa sobre la insalubridad de las ciudades.
La aparición del cólera Como consecuencia de la polución colectiva en las ciudades aparece en Europa, en 1832, el primer brote de cólera. Procedente de la India ${ }^{223}$ debido a las nuevas tecnologías de transporte como el barco de vapor y el ferrocarril, que facilitan que facilitan que los microorganismos viajen más lejos y más rápidos que antes ${ }^{224}$, esta primera enfermedad industrial ${ }^{225}$ se trasmite a través del agua contaminada por materias fecales, entre otras cosas.

La impresión sensible a través del sentido del olfato, propia de siglo XVIII, sigue teniendo una clara influencia sobre la explicación e identificación de la enfermedad. Tal y como ocurrió con la peste negra de 1348, se culpa a las mutaciones del aire y a sus emanaciones pútridas como los principales responsables de la nueva epidemia infecciosa. Mientras los científicos la justifican con la teoría de miasma, que privilegia al aire y a la tierra como transmisores de la enfermedad, los inspectores sanitarios la asocian a la miseria y a las pésimas condiciones de vida.

La teoría bacteriana La importancia que se le atribuye a los desechos y a los olores continúa obstaculizando la verdadera comprensión de la transmisión de la enfermedad. A pesar de que el médico inglés John Snow ya detecta en 1854, mediante un análisis cartográfico del distrito de Soho de Londres, que el cólera es causado por el consumo de aguas contaminadas con materias fecales ${ }^{226}$, relacionando los pozos de agua con las muertes, no es hasta el descubrimiento de la teoría bacteriana del ingeniero químico Pasteur, en la década de 1860, cuando se acepta que el paso de gérmenes de un organismo a otro es la causa de estas enfermedades infecciosas. 


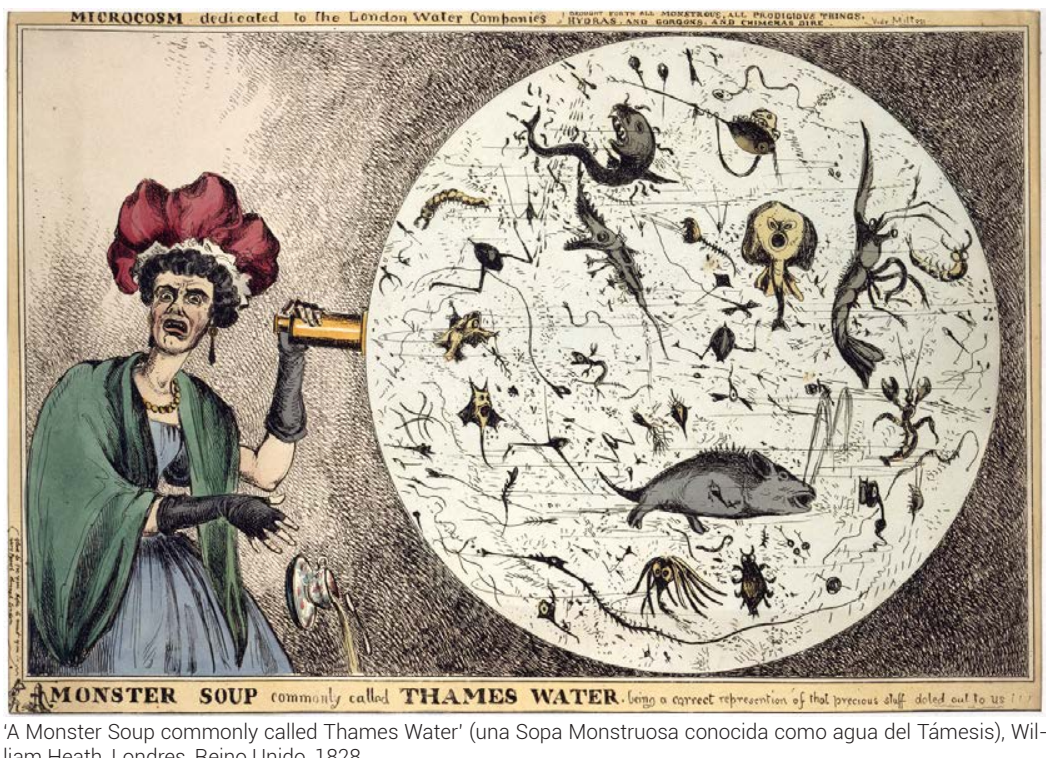

'A Monster Soup commonly called Tham
liam Heath, Londres, Reino Unido, 1828 .

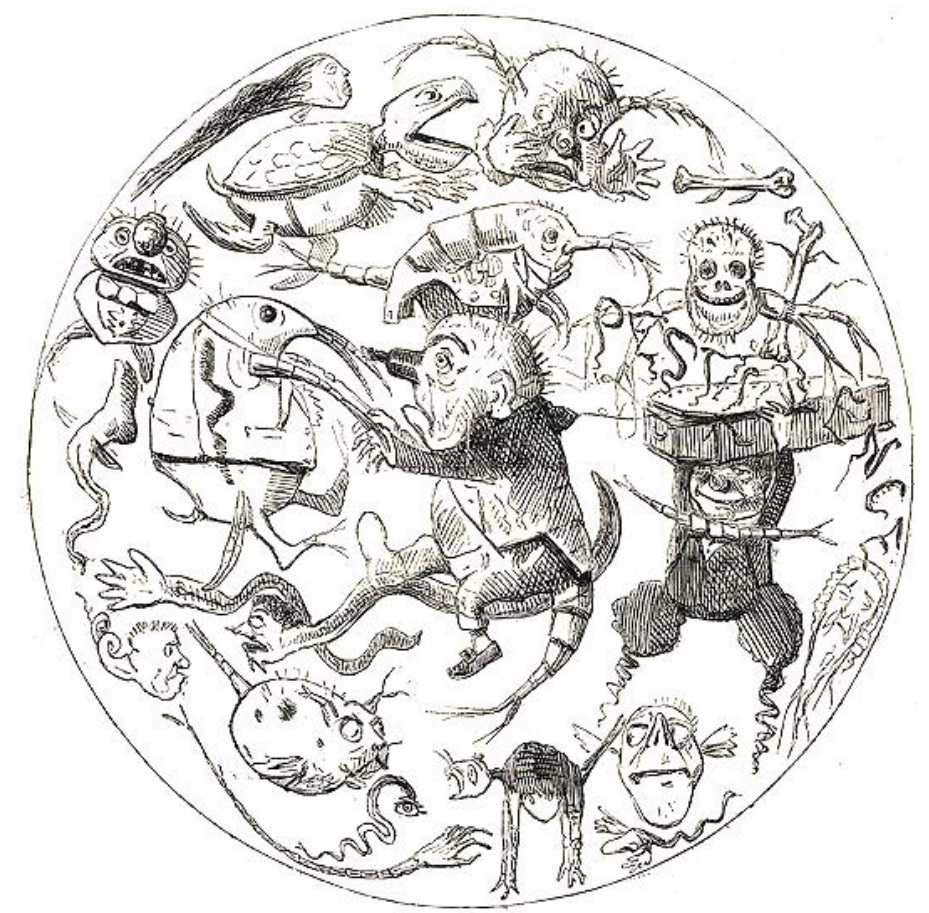

A drop of London water (una gota del agua de Londres), dibujo satírico de John Leech, Reino Unido, década de 185
El lavado de la piel A partir de este hecho, el agua cobra su verdadero valor, produciéndose una transformación de las recomendaciones higiénicas sin precedentes. La teoría microbiana de Pasteur pone de manifiesto la necesidad de cuidar la superficie del cuerpo, ya que su limpieza permite la aportación del oxígeno necesario que, a través de los poros, hacen a la piel más flexible y mejoran su funcionamiento.

Mientras que el fin de las prácticas regeneradoras de la antigüedad es la purificación interior, cuando aparece la higiene la limpieza corporal se convierte en un fin en sí mismo. Frente al carácter público, institucional y colectivo de la regeneración, la higiene, que nace en el contexto del cuidado del propio cuerpo y del descubrimiento de la intimidad, encuentra su ámbito en el espacio doméstico y en privado.

Cuando en la década de 1860 el agua se reincorpora a las técnicas de limpieza, al igual que ocurre con el uso de la ropa blanca en el siglo XVI, tiene una connotación de distinción social que contribuye a fijar una nueva imagen del cuerpo más allá de los modales: la higiene rehabilita la intimidad corporal y legitima la mejor utilización de los recursos orgánicos 227 .

El Estado Higienista Los descubrimientos de Pasteur también visibilizan que la población más expuesta a la enfermedad es aquella que concede menos importancia a las reglas de higiene, es decir, la masa industrial, que se transforma en una amenaza sanitaria para el resto de la sociedad228 Para poder controlarla mejor, el Estado, que desde 1802 cuenta con un consejo de médicos con atribuciones de vigilancia sanitaria, parece instituirse en 'Estado Higienista'229.

La asistencia y la disciplina social adquieren otro relieve, ya que el proteger la salud de algunos, sobre todo la de los más desfavorecidos, y también el obligarles a seguir ciertas pautas, requiere una inversión nacional que permita proteger mejor la salud de todos. El Estado industrial establece sus propios deberes, sumando a la ayuda protectora el control autoritario: no es admisible que un individuo pueda llegar a comprometer la salud de sus vecinos. Es el comienzo de la Higiene Pública ${ }^{230}$. 


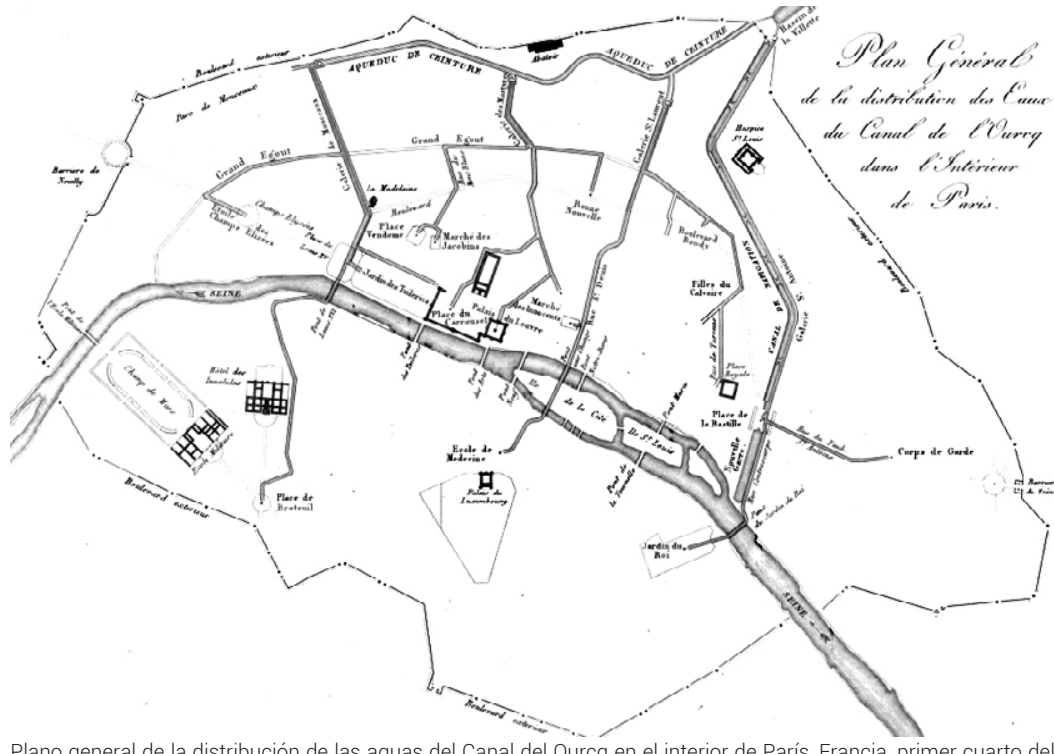

Plano $\mathrm{XIX}$
El control de los peligros de los sectores más pobres de la sociedad tanto en cuanto a los desperdicios físicos -inmundicias, mataderos...como también a los morales - prostitutas, traperos...- forma parte de los objetivos que redefinen el ámbito de la Salud e Higiene Públicas, que desde entonces, y a través de la encuesta como principal instrumento de evaluación ${ }^{231}$, cuentan con un número considerable de instituciones urbanas 232233

Sin duda el estímulo de la lucha contra el cólera es determinante para que las ciudades, apoyadas por las nuevas políticas sanitarias comiencen a intervenir en la mejora de nuevos sistemas para e suministro y la depuración del agua. De esta manera, y a pesar de una primera reticencia al proyecto institucional debido al carácter intrusivo de las infraestructuras necesarias, así como la prevalencia de la todavía dominante teoría del miasma ${ }^{234}$, se construye a partir de entonces toda una red de canalizaciones subterráneas que transforman la imagen de la ciudad tanto interior como exteriormente.

La conexión de la Aunque desde 1812 determinados barrios ricos disponen de agua vivienda con la red de corriente, por orden de Napoleón, la verdadera conexión de los abastecimiento hogares a la red de abastecimiento de agua se produce a mediados del siglo XIX ${ }^{235}$. El proceso de suministro es lento: la falta de la técnica necesaria para impulsar el agua provoca que las primeras veces esta no suba más arriba del sótano 236237 . Posteriormente, se conduce a través de tuberías hasta los pisos y, finalmente, a partir de 1870 llega a cada apartamento ${ }^{238}$; se abastece en primer lugar la cocina y por último el baño. De la misma manera, el agua caliente corriente, que es un lujo hasta 1920, al menos en Norteamérica, se lleva a los distintos aparatos en el siguiente orden: fregadero de la cocina, lavabo y, por último, a la bañera. 


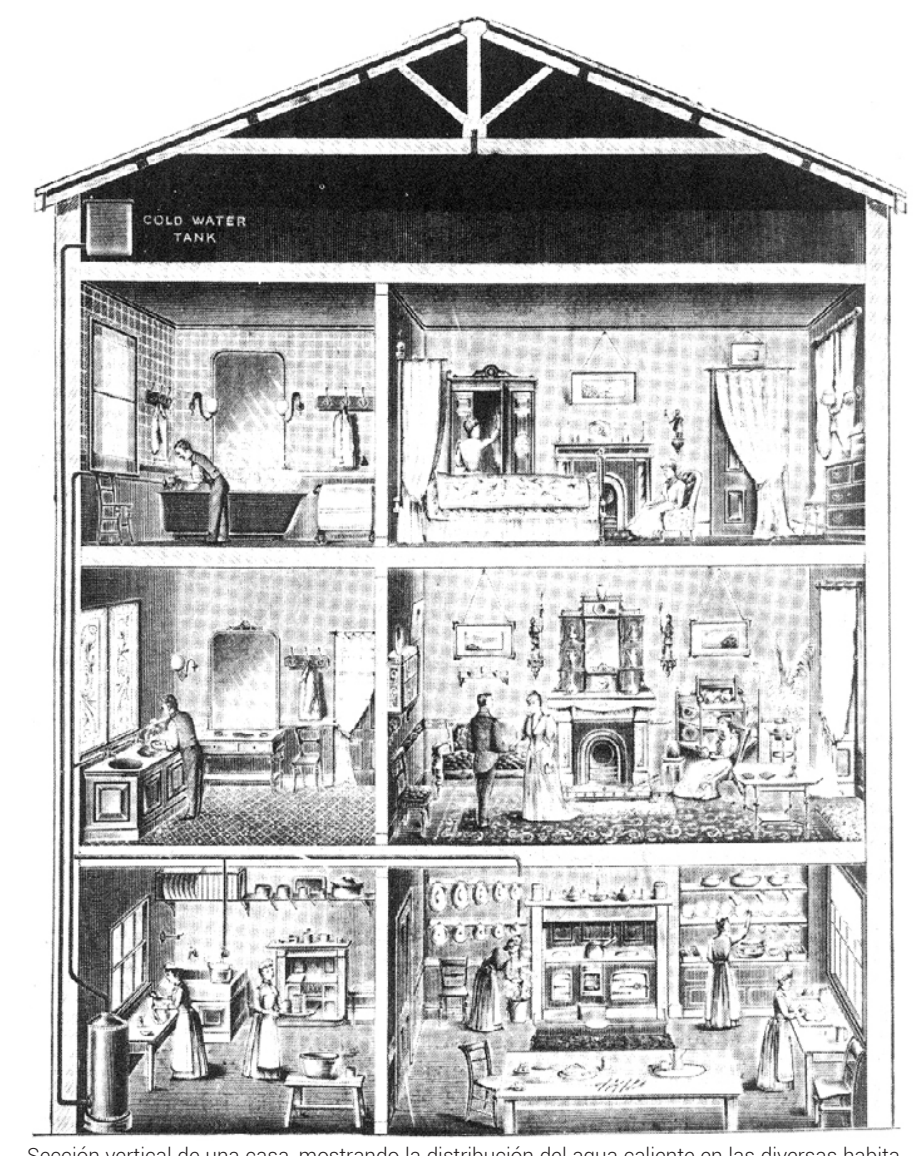

Sección vertical de una casa, mostrando la distribución del agua caliente en las diversas habita-

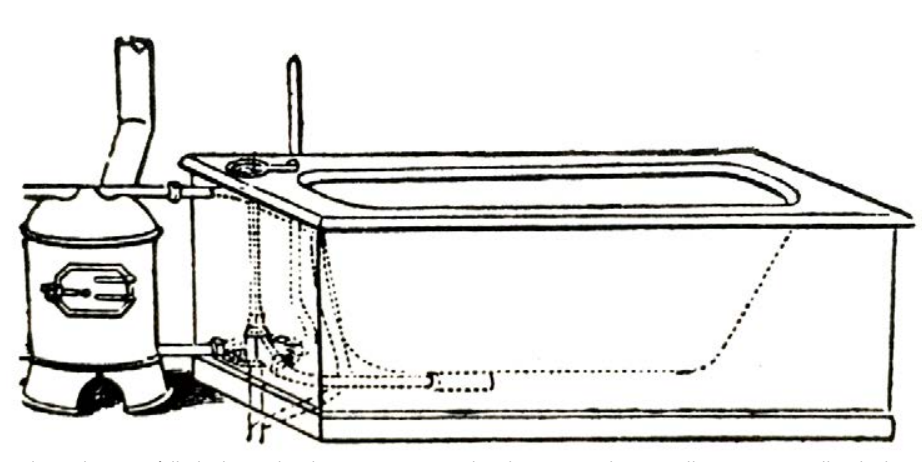

Calentador portátil de baño hacia 1850 . Se puede obtener un baño caliente por medio de la dirculación en cosa de me
Del baño frío Simultáneamente, según avanza el siglo XIX se tiene un mayor al baño caliente conocimiento de las características de la piel y de su necesidad de limpieza. Para quitarse la suciedad ${ }^{239}$, se pasa del baño frío, que estimula el sistema sanguíneo, al baño caliente en bañera, donde el control térmico del agua es un logro para conseguir el ideal higiénico, proporcionando una limpieza más eficaz.

La caldera Si bien el suministro de agua caliente en el espacio doméstico se realiza primero por medio de ladrillos calientes, luego con ollas calentadas en la chimenea o en la estufa, y más tarde, y en el sótano, en un 'cobre' 240 o con los ya mencionados aguadores a domicilio a partir de 1850, es la caldera construida en la cocina, y a través de tuberías, el sistema que se impone en las viviendas burguesas ${ }^{241}$ 242. La presencia del calor y del agua en la cocina del siglo XIX hace que bañarse y cocinar estén naturalmente aparejados, hasta que las normas modernas de higiene demanden un espacio especializado para cada función.

Paradójicamente, la disponibilidad de agua caliente en el baño es previa a que el agua fría sea conducida a los niveles superiores por medio de tuberías, ya que existen pequeños hornos portátiles conectados a unas bañeras todavía sin desagüe y llenadas a mano, también portátiles ${ }^{243}$ : bañera más calentador formando un juego portátil.

Ante la creciente demanda de aparatos, los fontaneros, los ebanistas, los ingenieros y los industriales se alían con el fin de domesticar la higiene, fabricando artilugios y complementos para el baño más cómodos y de mayor confort, que sustituyen el esfuerzo humano por el ingenio mecánico 244 


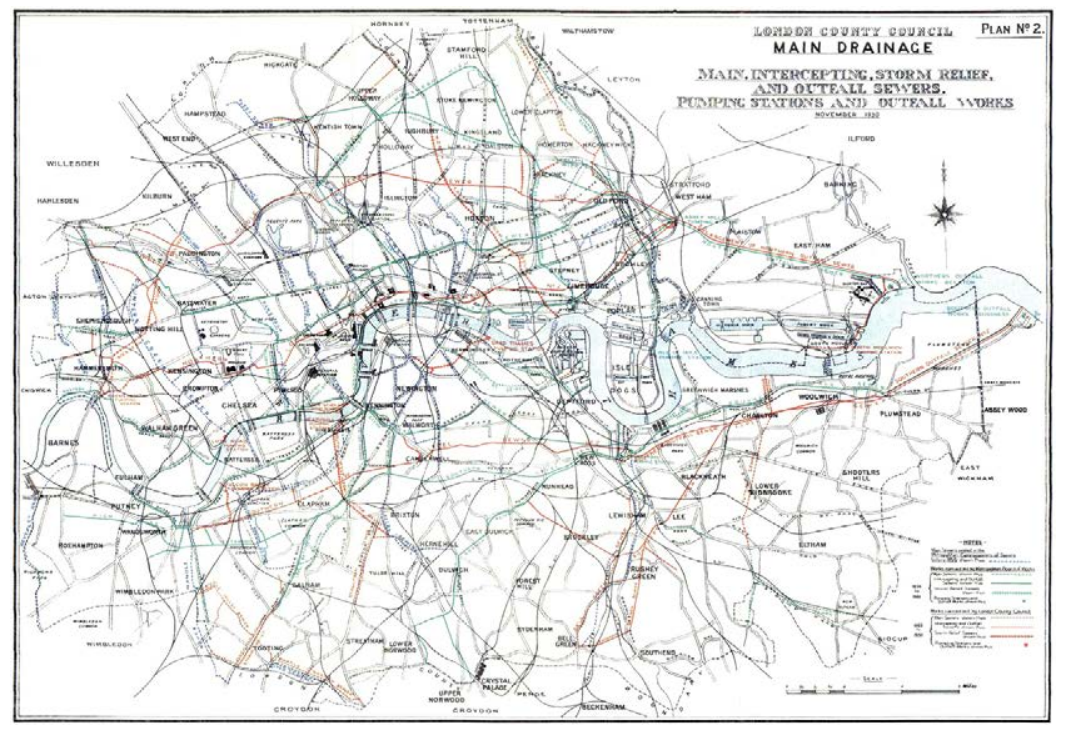

Plano de la red de alcantarillado de Londres, 1930

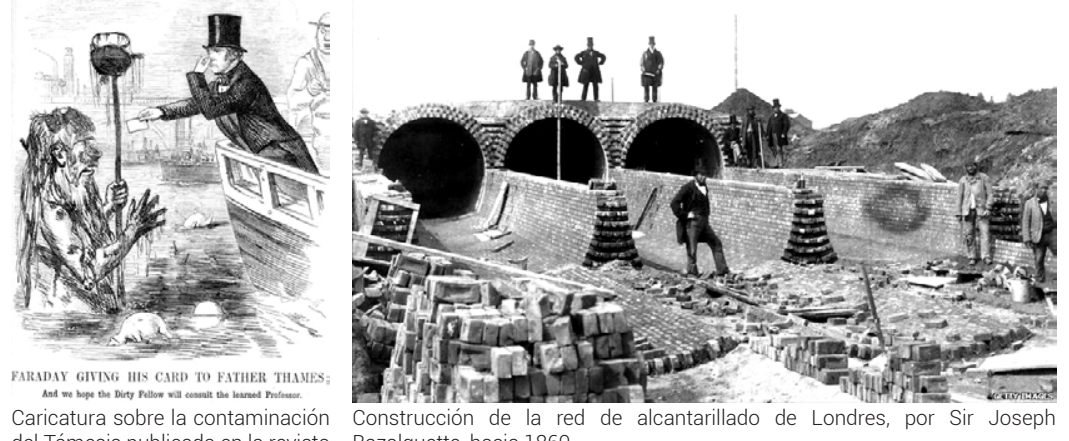

Pobre la contaminación satírica Punch el 21 de julio 1855
La conexión de la vivienda A la vez que aparece la red de abastecimiento de agua, y como a la red de saneamiento consecuencia de la revolución de la percepción olfativa ${ }^{245}$, iniciada a mediados del siglo XVIII y que dirige el sentido del olfato contra las heces ${ }^{246}$, tiene lugar el desarrollo de la segunda gran red que recorre subterráneamente la ciudad: el saneamiento.

Ya desde 1776 la alta tasa de mortalidad, debido a las epidemias, provoca una conciencia demográfica a la vez que revela la preocupación del Estado por mantener a la población, ya que según las teorías fisocráticas de la época 'sus brazos' son el origen de la riqueza del país. De este modo, el razonamiento económico impulsa una organización sanitaria de la colectividad y conduce a una transformación de la higiene de los grupos y de las comunidades ${ }^{247}$ Por otro lado, durante el siglo XVIII hay una serie de intentos físicos fallidos de recoger las materias fecales. Consisten primero en la creación de una hendidura longitudinal en las calles de la capital donde se instala un arroyo en medio de la calzada, y más adelante en su sustitución por una calzada abombada con canaletas a los lados. Pero hay que esperar hasta la creación del alcantarillado para que las heces desaparezcan de la vista y del olfato.

De la misma manera que la red de abastecimiento de agua, la red de alcantarillado llega, desde principios del siglo XIX, a las partes más aristocráticas de la ciudad ${ }^{248}$. Sin embargo, no es hasta la década de 1850 -dos años después de La primera ley de Sanidad Pública- 249250 cuando comienza la sustitución de los pozos negros por alcantarillas con la consecuente desaparición de los 'hombres nocturnos' (caballeros nocturnos) 251

El Gran Hedor Es probable que el ciclo climático de sequía extrema que asuela Europa en el verano de 1858 en Londres -El Gran Hedor-252 sea el responsable de la implantación definitiva, en 1865, de la nueva red de alcantarillado, bajo la dirección de Joseph Bazalgette, que con un recorrido de 153 kilómetros de grandes sumideros llega a transportar 1890 millones de litros de agua al día ${ }^{253}$.

245 CORBIN, Alain. Op.cit. 85.

246 LAPORTE, Dominique. Op.cit.35.

${ }_{248}^{247}$ Esta aristocracia es en parte la responsable de la propagación de la enfermedad, ya que el contenido de esta primitiva red contamina los pozos y los ríos por la mala conservación de las tuberías.

${ }_{250}^{29}$ En ese mismo año, 1848 , que coincide con la aparición de un nuevo brote de cólera, el control del saneamiento de Londres, que hasta entonces está dividido entre ocho indiferentes organismos, se confía a una Junta de Comisarios, una agencia centralizada cuyo propósito es el de implementar programas de sanidad pública de largo alcance.

al de las materias orgánicas de la capital inglesa.

${ }^{253}$ WRIGHT, Lawrence. Op.cit. 195. 

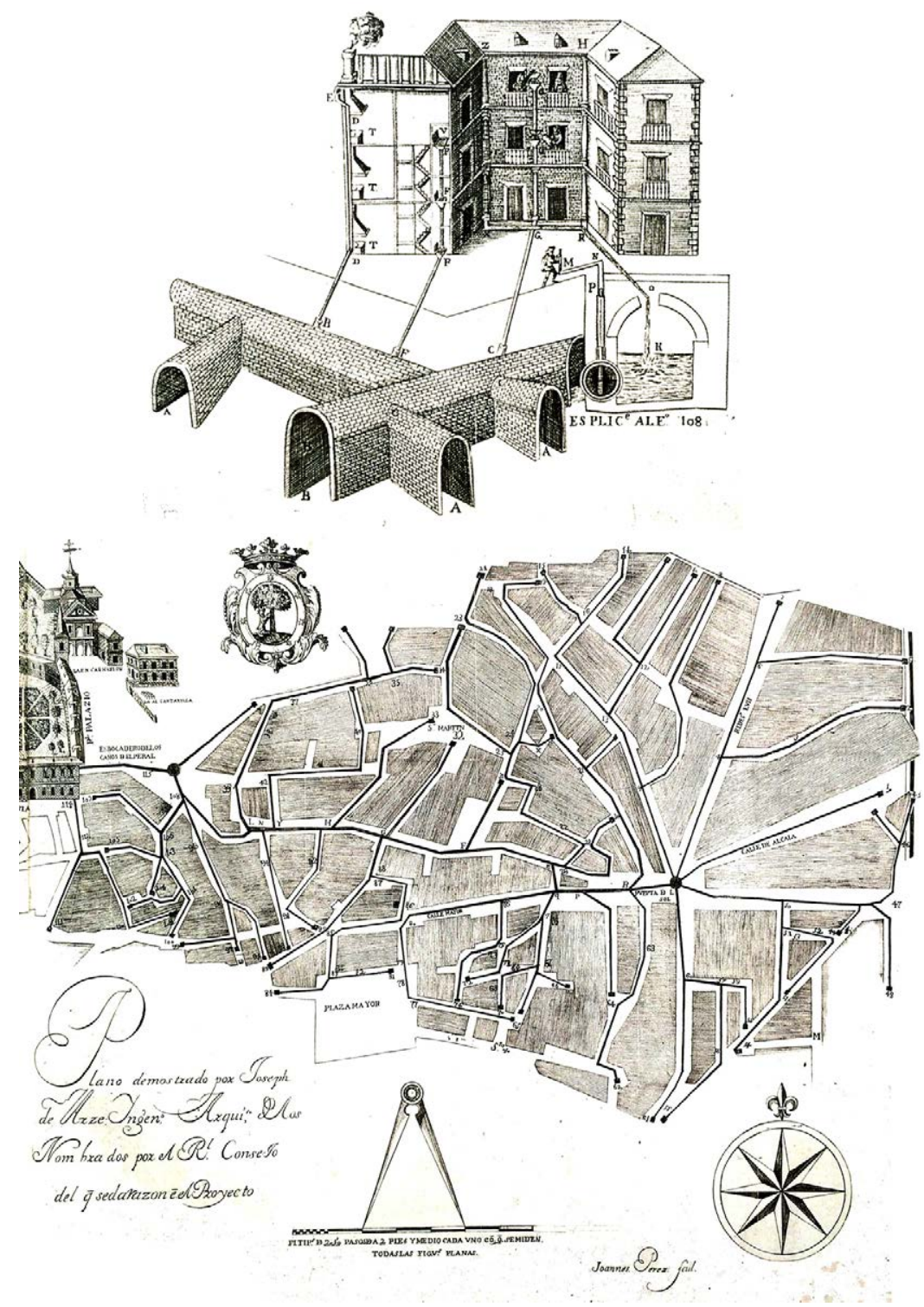

(Arriba) Alzado y seccion de una vivienda de varios pisos con sus vertederos y alcantarillas, seccion de un sifon

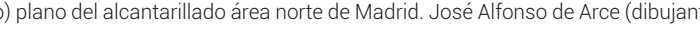
Joannes Pérez (grabador), 1823.
La implantación del sistema En cualquier caso, y a pesar de la reticencia de los partidarios del de alcantarillado abono humano, el sistema de alcantarillado termina por imponerse progresivamente a lo largo del siglo XIX en muchas capitales como Berlín (1860), Hamburgo (1842), Chicago (1855), Nueva York (1842) o Madrid (1851)254 255. La intervención urbana más eficaz es, sin duda, la que lleva a cabo Haussmann en París, sobre todo entre 1850 Y 1870 aunque las obras comienzan a partir de $1830^{256} 257$.

Al igual que la Cloaca Maxima de Roma hace diecinueve siglos, las galerías de abastecimiento y suministro de agua son los órganos de la gran ciudad que, análogamente al funcionamiento del cuerpo humano, la recorren subterráneamente: el agua limpia y fresca, la luz y el calor circulan como fluidos diversos cuyo movimiento y mantenimiento son necesarios para la vida en la superficie ${ }^{258}$ 

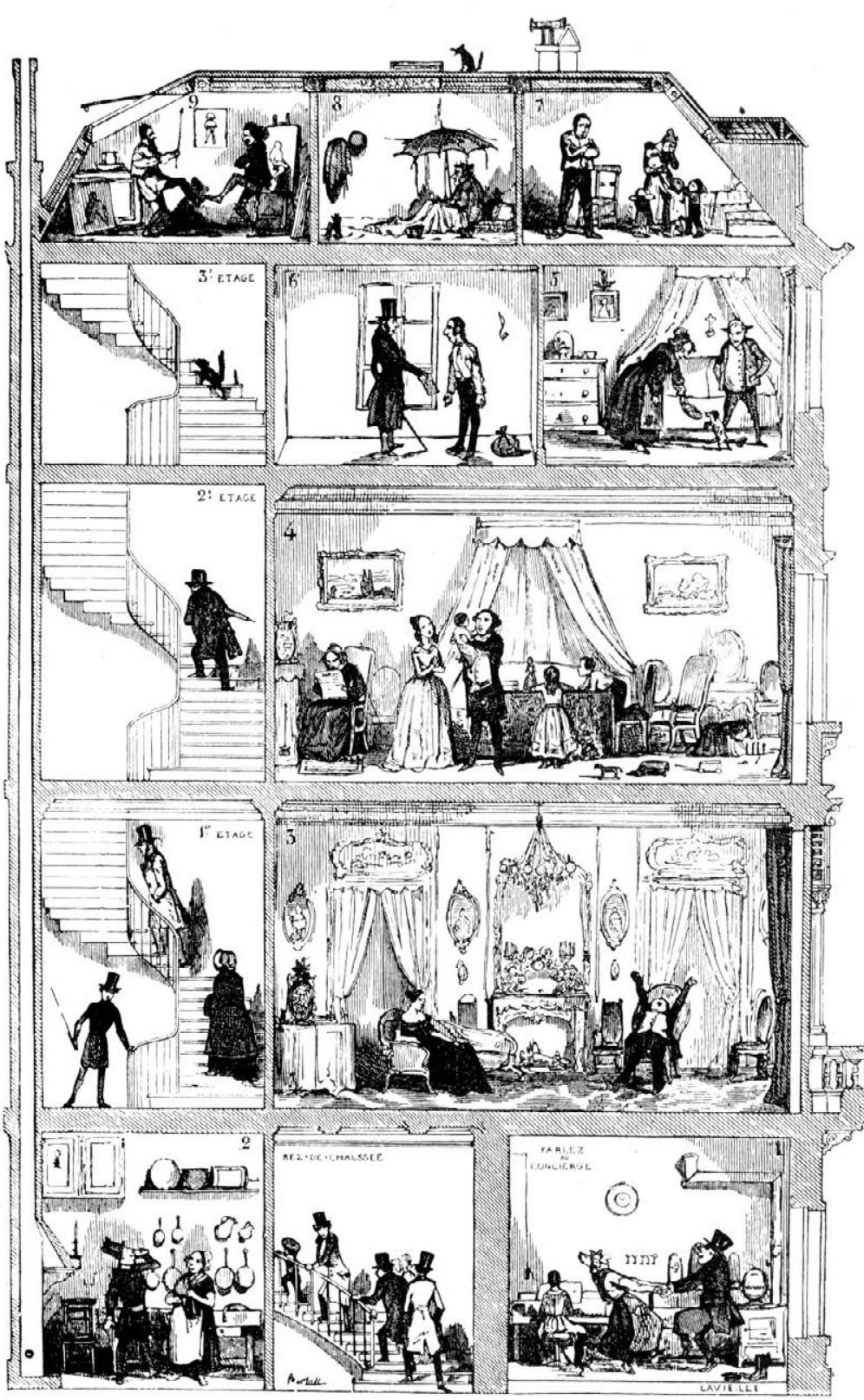

Sección de un edificio parisino de 1853
Si bien desde el siglo XVIII, y hasta la primera mitad del siglo XIX, es frecuente que los inmuebles sean social y económicamente 'mixtos', donde las clases más pudientes ocupan los pisos bajos y las menos favorecidas las buhardillas, a partir de la ampliación de las ciudades ${ }^{259}$ y sobre todo de la invención del ascensor, en la segunda mitad de siglo XIX260 desaparece ese microcosmos social, siendo desplazada la población más pobre a las afueras de la ciudad y manteniéndose los burgueses en el centro ${ }^{261}$

Desde entonces, el piso burgués recoge las funciones de representación social en el salón y el comedor, y de espacio privado de intimidad en los dormitorios. También dispone de unos espacios retirados, como la cocina y los aseos, de función más compleja ${ }^{262}$. El hecho de situar fuera de la vista dos piezas que asumen las funciones de transformación y de exoneración, pone de manifiesto el desprecio que la burguesía siente por los desperdicios y por las cuestiones relacionadas con el propio cuerpo. En particular esto se da con el excusado, que se coloca en cualquier lugar de la casa; incluso, a veces, junto a la cocina.

La paulatina conexión de las viviendas burguesas a las redes subterráneas de la ciudad es uno de los hechos técnicos más importantes para que se produzca la implantación definitiva de la higiene en el hogar.

La industrialización También la aportación que hace el desarrollo y la fabricación de de los aparatos sanitarios productos en serie, a partir de la industrialización, alrededor de 1880 es determinante para alcanzar este ideal higiénico, con la difusión de los aparatos sanitarios. En un principio, la industria asume la gran variedad de artilugios higiénicos presentes en la ya mencionada Exposición de 1851 en Londres, y a partir de finales del siglo XIX se centra en el desarrollo de los más viables, como la bañera, la ducha, el lavabo -jofaina mecanizada-, y el inodoro -retrete con cierre sifónicoDesde entonces, estos aparatos, cada vez más estandarizados, comienzan a ser objeto de numerosos catálogos industriales que el ciudadano medio puede 'personalizar' gracias a la amplia variedad existente en el mercado 263264. 


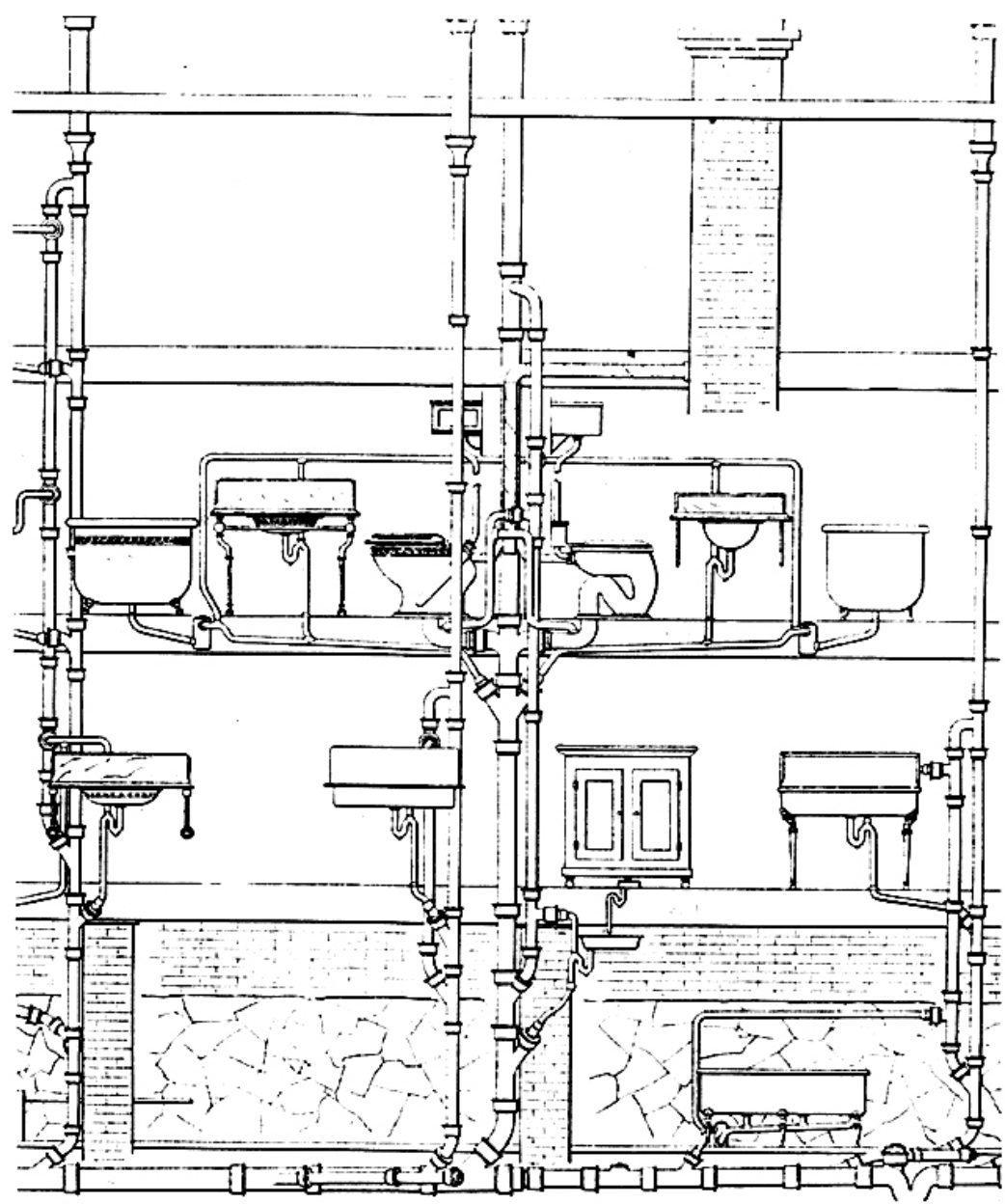

De lo nomada a lo estable, dibujo de Adolf Loos, segunda mitad del s. XIX.
Tanto la conexión de la vivienda con las redes subterráneas como la posibilidad de adquirir cualquier aparato sanitario son dos hechos impensables para la mayoría de la población, por lo menos hasta después de la Primera Guerra Mundial.

De lo nómada a los estable En cualquier caso, gracias a estos avances tecnológicos, en las viviendas burguesas de la segunda mitad del siglo XIX el baño pasa de una condición nómada a otra estable ${ }^{265}$ : el baño portátil se convierte en un baño fijo, anclado a una compleja red de tuberías y elementos de ventilación.

La aparición del cuarto de Finalmente, hacia 1870, a la vez que se produce el desarrollo de las baño redes urbanas y la disposición de aparatos especialmente diseñados para beneficiarse de sus ventajas, aparece en distintas capitales europeas, dentro del espacio doméstico, una habitación destinada exclusivamente al disfrute de los efectos de la higiene: el cuarto de baño ${ }^{266}$.

A pesar de ser la higiene el motor que impulsa la creación de estos nuevos espacios en la vivienda, el desarrollo del cuarto de baño adquiere, en el mismo tiempo de expansión, distintas formalizaciones y significados dependiendo de si se trata de su versión europea ${ }^{267} \mathrm{o}$ americana.

El cuarto de baño burgués De la misma manera que la vivienda burquesa se especializa espacialmente en el siglo XVIII, como consecuencia de un cambio de necesidades, la aparición del cuarto de baño en la casa de los entornos económicamente acomodados significa tanto el reconocimiento social de la actividad como la confirmación de un hábito que permite exhibir en ella todos los nuevos aparatos sanitarios que se inventan a lo largo del siglo XIX 


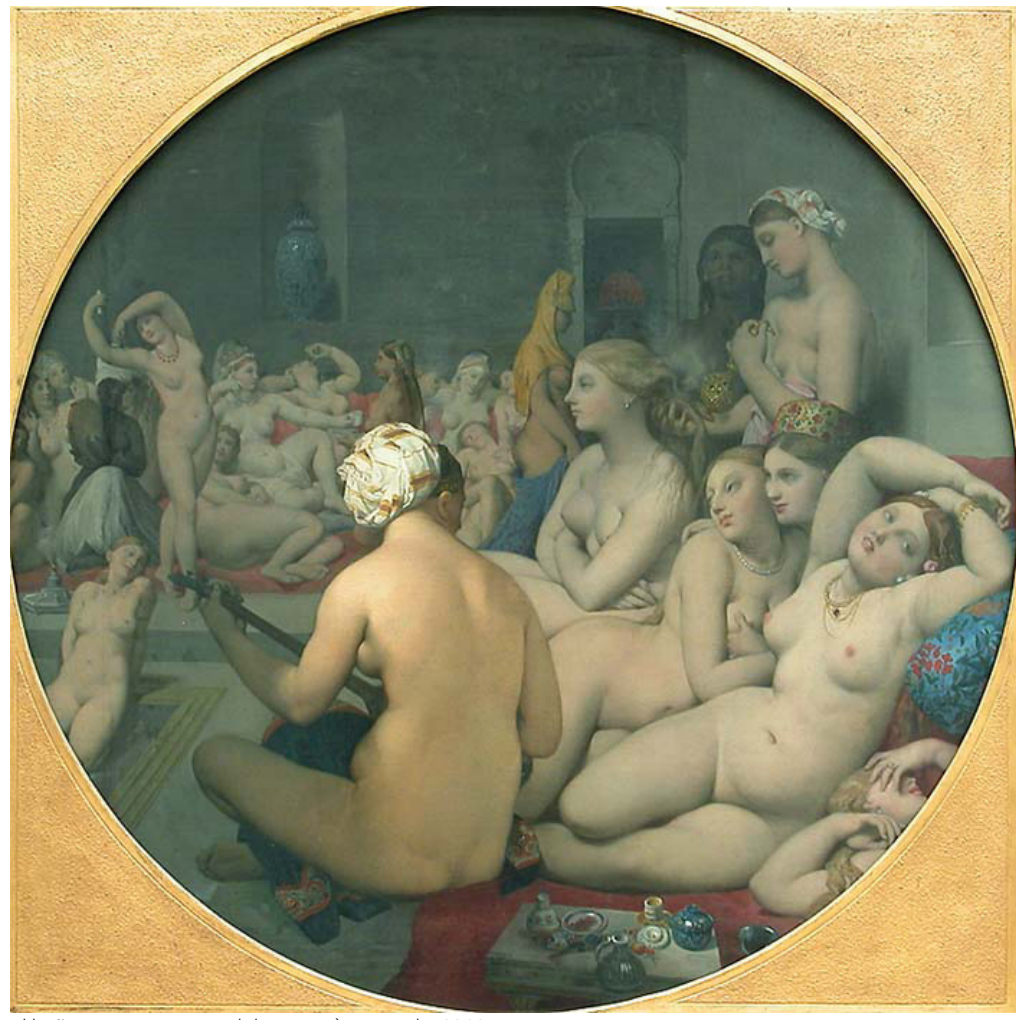

El baño turco, Jean-Dominique Ingrès, Francia, 1862.

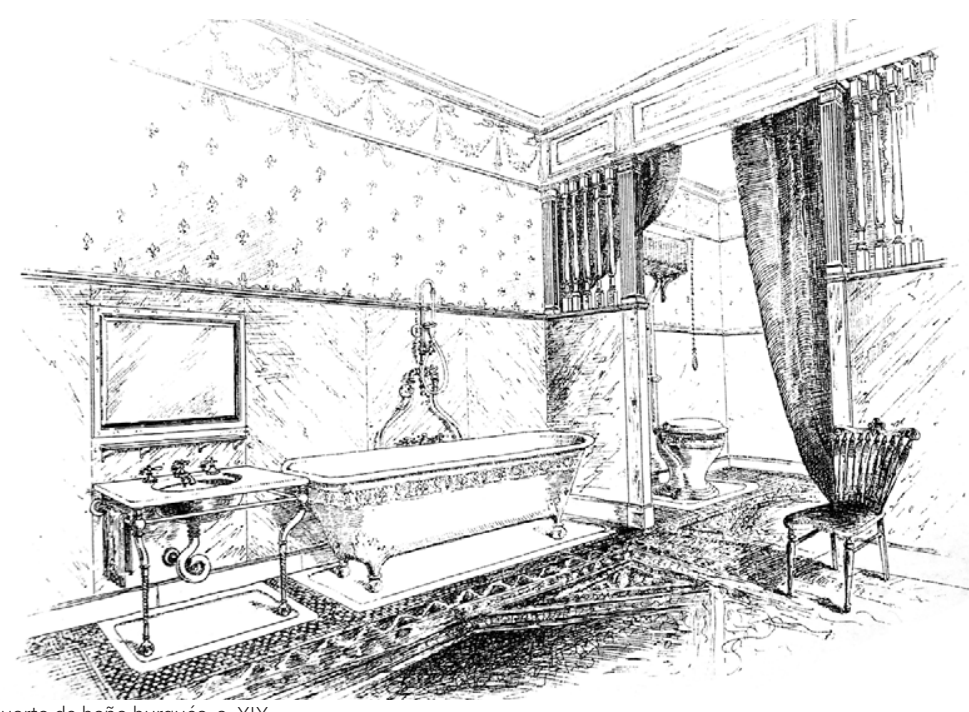

La Antigüedad Las primeras ubicaciones del cuarto de baño dentro del espacio como fuente de inspiración tanto como de la disponibilidad del espacio o de los recorridos del agua ${ }^{268}$. De esta manera, las soluciones más frecuentes aprovechan un espacio pequeño de la casa ya existente, como el tocador, la sala de fumar o los descansillo de las escaleras, entre otros 269 ; o bien se construye expresamente, y, en este último caso, la imagen tanto física como formal de estas nuevas habitaciones tienen sus orígenes fuera del espacio doméstico: se toma de la recreación de los grandes centros de regeneración de la Antigüedad, como consecuencia de la actitud historicista del momento. Las antiquas termas romanas y los establecimientos públicos orientales de tipo termal son recuperados en la vivienda con el fin de disponer en el espacio doméstico de un lujo privado hasta entonces accesible solo a reyes y príncipes.

Consecuentemente, el cuarto de baño burgués se configura como un espacio desproporcionado y amueblado como cualquier otra habitación de la casa destinado a la exhibición y el lujo.

La fuerte inversión económica que reclama un espacio así es la responsable de que se presente como una única habitación para el uso de toda la familia ${ }^{270}$. Sin embargo, no es comunitario en el sentido en el que lo son los baños de la Antigüedad: en él se superpone la intimidad de cada miembro de la casa. De esta manera, el cuarto de baño burgués se configura como un espacio que por primera vez es público y privado, individual y colectivo.

En un mismo espacio se aglutinan todos los aparatos destinados a orden, a la higiene y a la belleza271: la ducha, la bañera, los baños de asiento, el bidet y los lavabos con repisa de mármo|272. Respecto al retrete, durante esta época, y en países pioneros en materia de higiene como Francia o Inglaterra, existen ciertas reticencias a alojarlo en la misma habitación con el resto de aparatos higiénicos muchas viviendas lo encierran en un pequeño cubículo con entrada independiente, aunque adosado al recinto del baño. En otros casos, el retrete está situado en otra parte de la casa, e incluso compartido con otra vivienda del mismo bloque. 


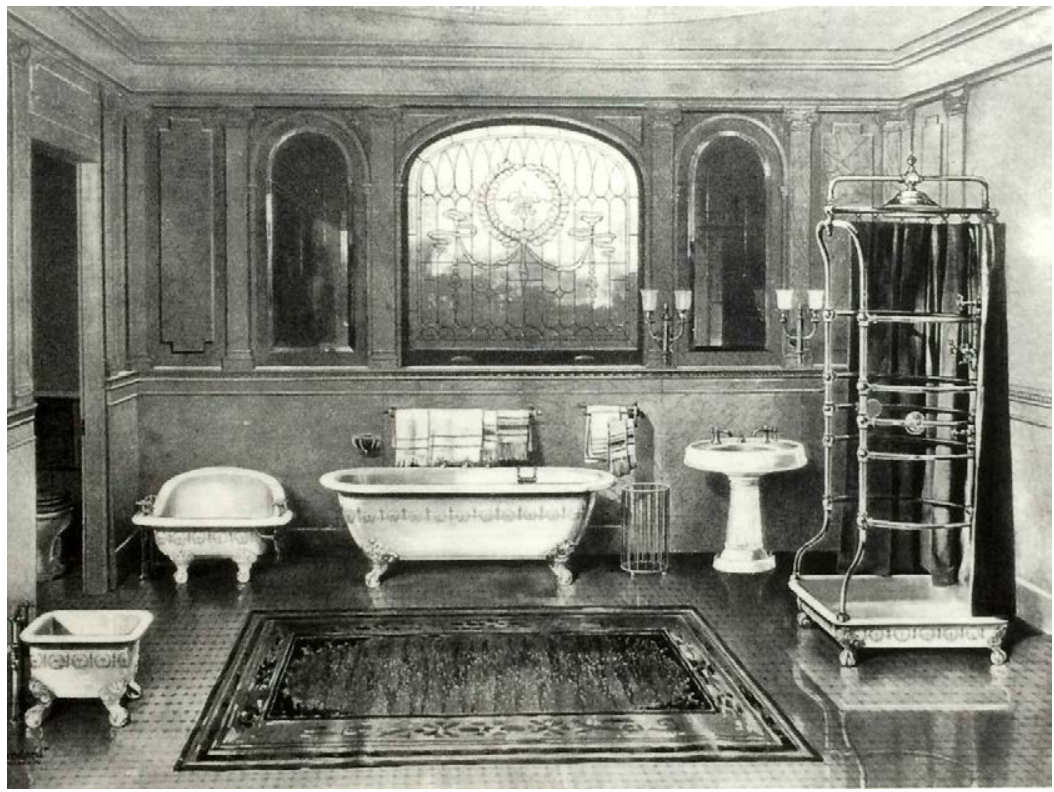

Cuarto de baño burgués de la segunda mitad del s. XIX.
Ventanas con vidrieras de colores y cortinas adornadas con borlas, columnas jónicas, mármol de Siena, alfombras y los cada vez más populares azulejos decorados, tanto en suelos como en paredes ${ }^{273}$, terminan por completar el aspecto material-constructivo de esta nueva estancia.

Los plumber Desde la instalación del cuarto de baño en la casa burguesa a finales del siglo XIX, la arquitectura y la tecnología avanzan por separado. En un principio, los arquitectos, más interesados por el aspecto de sus edificios que por su funcionamiento ${ }^{274}$, son completamente ajenos a los progresos en la eficiencia doméstica y sus implicaciones constructivas. En su lugar, son los ebanistas ${ }^{275}$, en colaboración con los ingenieros e instaladores especializados, más conocidos como los plumber o installateur -actuales fontaneros-276 277 , los que asumen las implicaciones constructivas del espacio doméstico vinculadas a su organización para la limpieza y la civilización ${ }^{278}$. Como señala el arquitecto Adolf Loos en un escrito publicado en 1898, sin los plumber no existe el siglo XIX ${ }^{279}$ : con una mentalidad de negocios basada en la eficiencia, ellos son los verdaderos artífices del entorno doméstico.

La disposición de un cuarto de baño bien equipado en las casas de las altas clases sociales se convierte en una obligación ${ }^{280}$. Sin embargo, esta situación es paradójica si tenemos en cuenta que en 1880 el baño diario es, todavía, algo inimaginable. El cuarto de baño burqués apenas se utiliza, y en muchas casas se usa como trastero, sobre todo la bañera, que solo recobra su función original el día de San Silvestre ${ }^{281}$. Esta situación pone de manifiesto cómo la sala del baño durante esta época es un lugar de 'representación social' que se tiene más por estar a la moda que por necesidad, donde la higiene, de momento, es un aspecto secundario. 

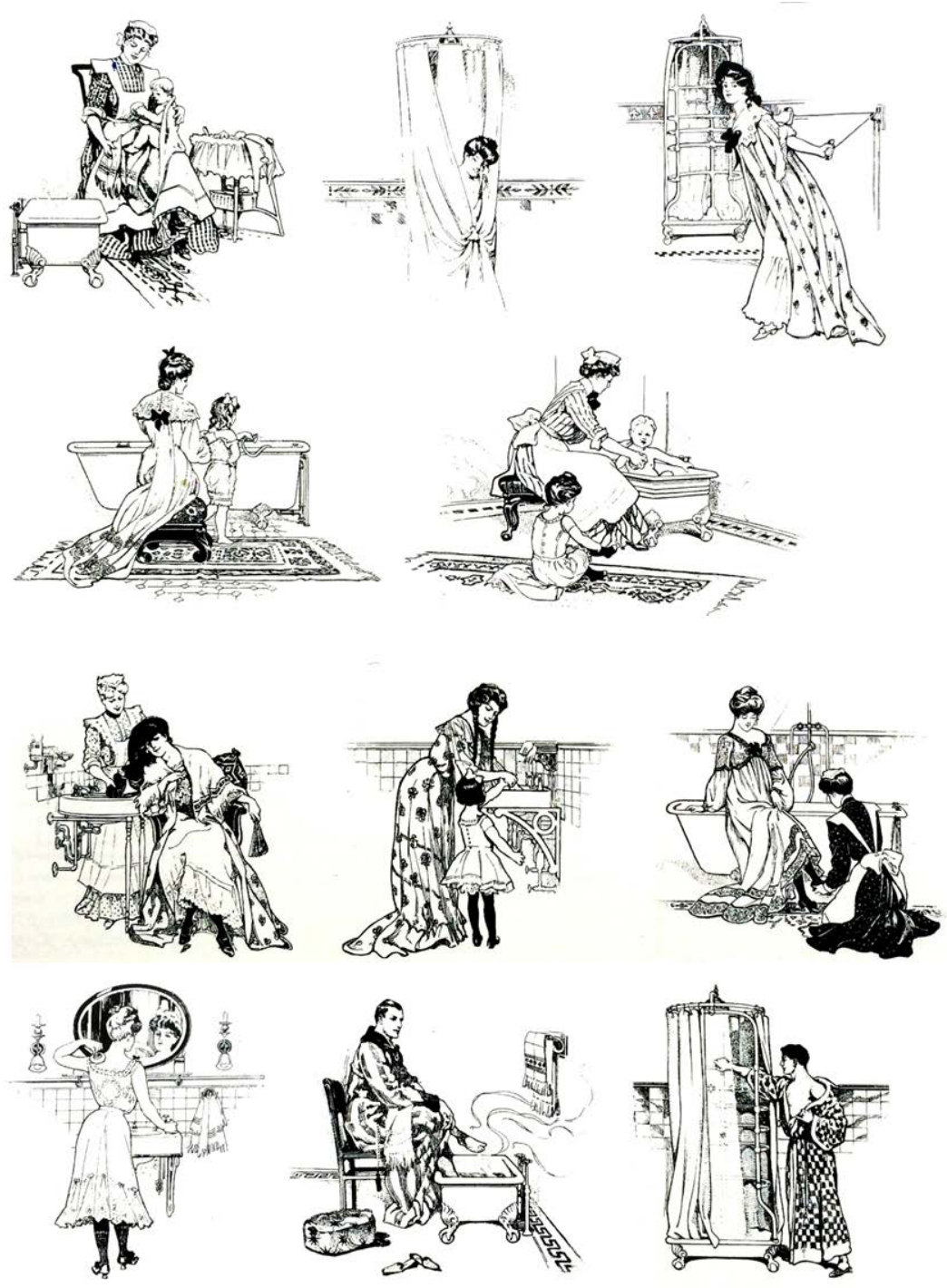

El cuarto de baño Es probable que la causa de esta falta de conciencia higiénica sea norteamericano en parte la tradición cristiana. De la misma manera que ocurre en el siglo XVI, cuando la Reforma prohíbe definitivamente el baño en toda Europa, a finales del siglo XIX la antítesis evangélica carne/espíritu surge como una oposición entre la carne y el alma: el cuerpo es la prisión del alma, al que hay que conceder los cuidados indispensables, ya que prestarle demasiada atención significa exponerse al pecado ${ }^{282}$

De esta manera, y a pesar de que el desarrollo de la vida de representación de la burguesía en muchas ocasiones exige que se le dé importancia a la apariencia física, una vez más vuelven a ser las partes visibles del cuerpo, el rostro y las manos, las que se cuidan, reservándose los baños de cuerpo entero para las ocasiones de enfermedad o antes de contraer matrimonio ${ }^{283}$

Esta limpieza dista mucho de la nuestra, aunque no cabe duda de que es decisiva, ya que lleva implícita muchos de los avances técnicos, científicos e ideológicos de los últimos siglos, absolutamente necesarios para que la limpieza termine alcanzado a toda la piel, tanto a sus zonas visibles como a las más ocultas.

En la época en la que se desarrolla el cuarto de baño burgués europeo comienza a idearse en las viviendas americanas una habitación cerrada y pequeña como baño. Una nación como EE. UU., desprovista de memoria histórica y por tanto de prejuicios culturales en relación con la vivienda, facilita que la higiene y sus formas asociadas avancen con mayor rapidez.

La higiene burguesa. Las distintas actividades que ocurrían dentro de un baño burgués de de finales del s. XIX. 


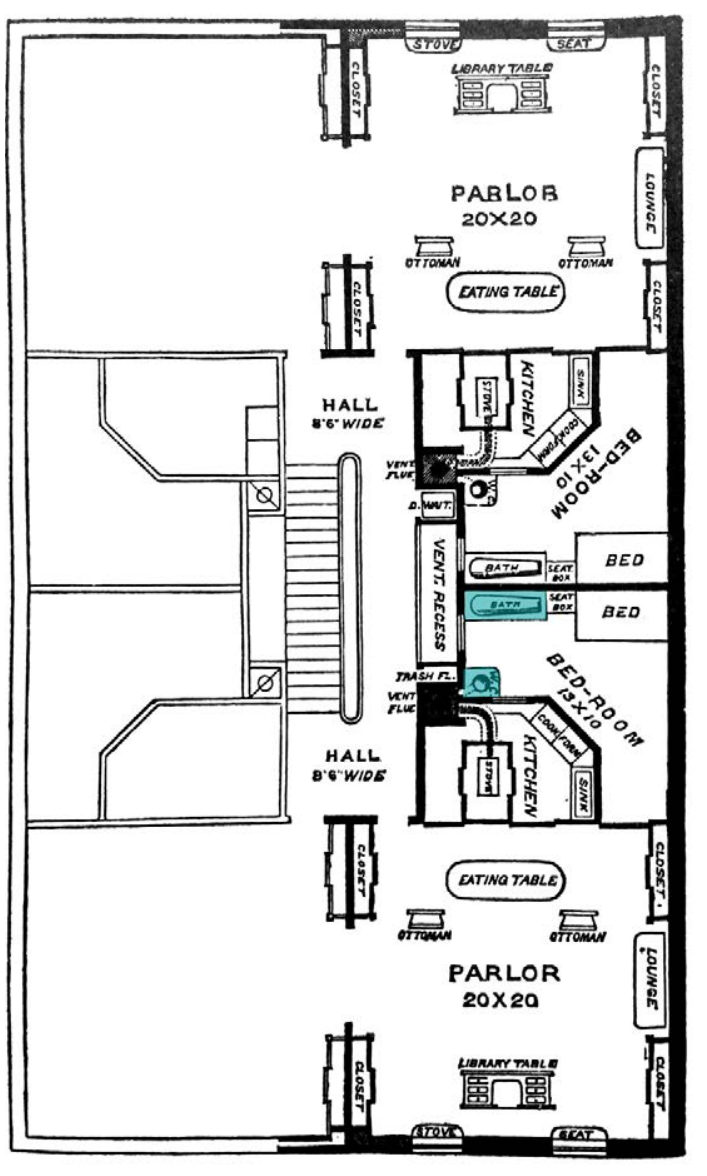

Planta de un apartamento de cludad, con dormitorio, cocina y baño, Catherine Beecher, Estados Unidos, 1869
El hotel norteamericano Mientras que el bañoburgués tiene sus orígenes enlas grandilocuentes como impulsor del cuarto y lujosas escenas de la antigüedad, en los baños turcos o en las de baño stuffetas clásicas, el baño americano encuentra su referente formal en una tipología emergente de la época: el hotel284 285

El hotel, que aparece en las primeras décadas del siglo XIX como consecuencia de la expansión del territorio americano, da una oportunidad para establecer un primer contacto con las bañeras, el agua corriente sanitaria y el retrete.

Con el objetivo de ofrecer el mayor confort a sus clientes, lo novedoso de esta tipología es que equipa a todas las habitaciones con un baño pequeño -compuesto de una bañera con ducha, un lavabo y un retrete- y agua corriente dentro de las mismas. Es el caso del Hotel Mount Vernon en Cape May, en Nueva Jersey, el primer establecimiento turístico hotelero que cuenta desde 1853 con este tipo de instalaciones ${ }^{286}$

La tendencia del Mount Vernon a combinar las instalaciones de fontanería en el menor espacio posible aparece también en la planta de un apartamento urbano compuesto por salón, cocina y dormitorio, que Catherine Beecher publica en su libro 'The American Woman's Home' -La casa de la mujer americana- en 1869. Al igual que la cocina de Beecher se anticipa en parte por su distribución a la cocina actual, es la disposición en el dormitorio de los distintos aparatos sanitarios, reservando así un rincón a la higiene, el precursor de la unidad dormitorio-cuarto de baño de dimensiones totales poco pretenciosas ${ }^{287}$

La auténtica aportación de Beecher consiste en saber incluir en la vivienda los criterios de eficiencia y pragmatismo ${ }^{288}$, lo que se manifiesta en sus ajustadas dimensiones, que la hacen económicamente asequible a las familias con pocos recursos 289290 


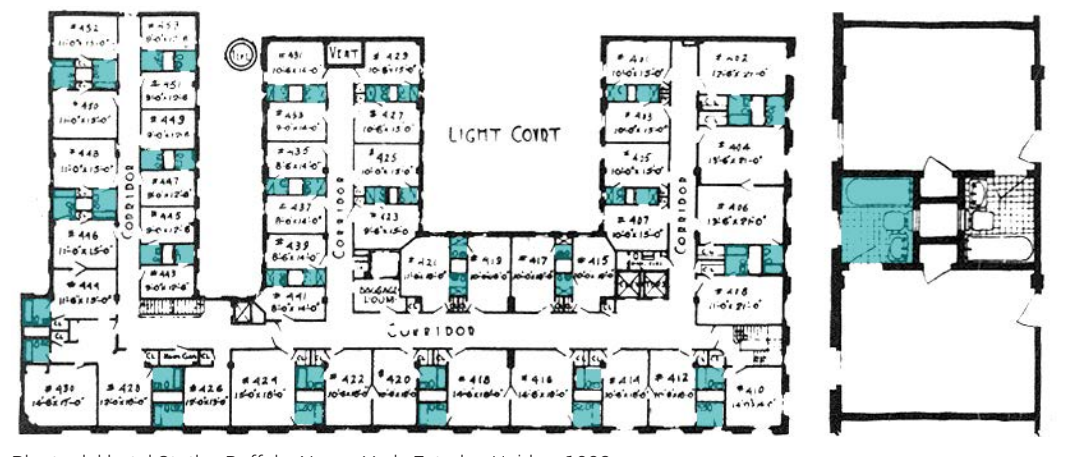

Planta del hotel Statler, Buffalo, Nueva York, Estados Unidos, 1908.
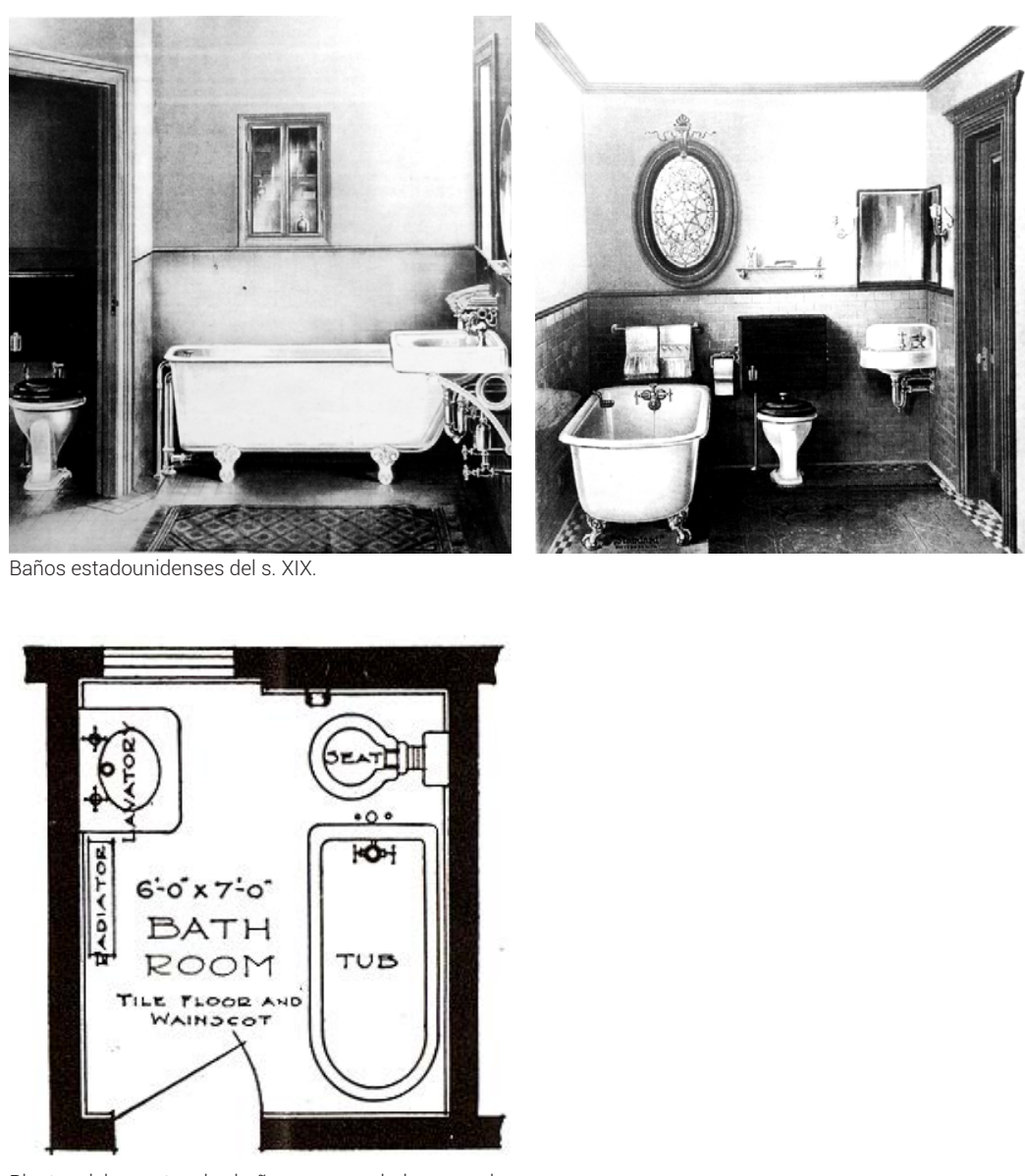

Planta del cuarto de baño recomendado para la
servidumbre en Book of Distinctive Interiors, Vollmer 1912 .
A pesar de los repetidos intentos por incluir dentro del dormitorio un baño, hay que esperar hasta 1908, a partir de la democratización de hotel${ }^{291}$ y el desarrollo en la técnica de los rascacielos y su equipo sanitario 292293 , cuando se importa definitivamente a las viviendas medias americanas la célula del cuarto de baño 294

Los primero catálogos de En las primeras organizaciones domésticas del cuarto de baño en baños América, presentadas a través de la publicidad de los catálogos de la Standard Sanitary Company -la principal empresa de sanitarios de país-, la distribución del inodoro, el lavabo y la bañera se disponen adosados linealmente a una pared.

El cuarto de baño compacto No es hasta que la bañera gira $90^{\circ}$, y se coloca en una posición transversal, cuando todas las instalaciones se conectan en una pared dando lugar al cuarto de baño compacto. El giro de la bañera, hasta ponerla paralela al lado más corto, se toma por norma. Se establece su longitud estándar en 1.5 metros, marcando la anchura de la celda, cuya longitud corre a cargo del lavabo y el retrete, colocados a una distancia mínima.

Desde entonces, la unidad del cuarto de baño de 1.5 metros de ancho se hace estándar y las viviendas se acogen a estas disposiciones más propias del pragmatismo del espíritu comercial de las empresas hoteleras que de un hogar tradicional295.

Sin duda esta nueva concepción compacta de la habitación de baño tiene que ver con una cuestión esencialmente dimensional relacionada con la fontanería y la economía de las instalaciones, reduciendo así los costes en la construcción. Desde otro punto de vista, esta simplificación del espacio también implica el paso, en 1915, de la bañera exenta sobre patas a la bañera empotrada de doble pared y esmaltada. Su fabricación en serie y de solo una pieza, ya en 1920, permite reducir los costes de la fabricación del cuarto de baño, facilitando su democratización ${ }^{296}$.
291 Una cama y un baño por un dólar y medio es el eslogan para el alquiler barato, en 1908, de una unidad a base de dormitorio y cuarto de baño que se da en el Statler Hotel en Buffalo. (GIEDION, Siegfried. Op.cit. 690).

202 GIEDION, Siegfried. Op.cit. 691 .

293 Como en tantos otros aspectos, la ciudad de Chicago es pionera en el desarrollo de los edificos en altura, que es paralelo al desarrollo del equipo sanitario. 224 GIEDION, Siegfried. Op.cit. 689.

2956 GIEDION, Siegfried. Op.cit. $689-692$.
296 GIEDION, Siegfried. Op.cit. 692. 

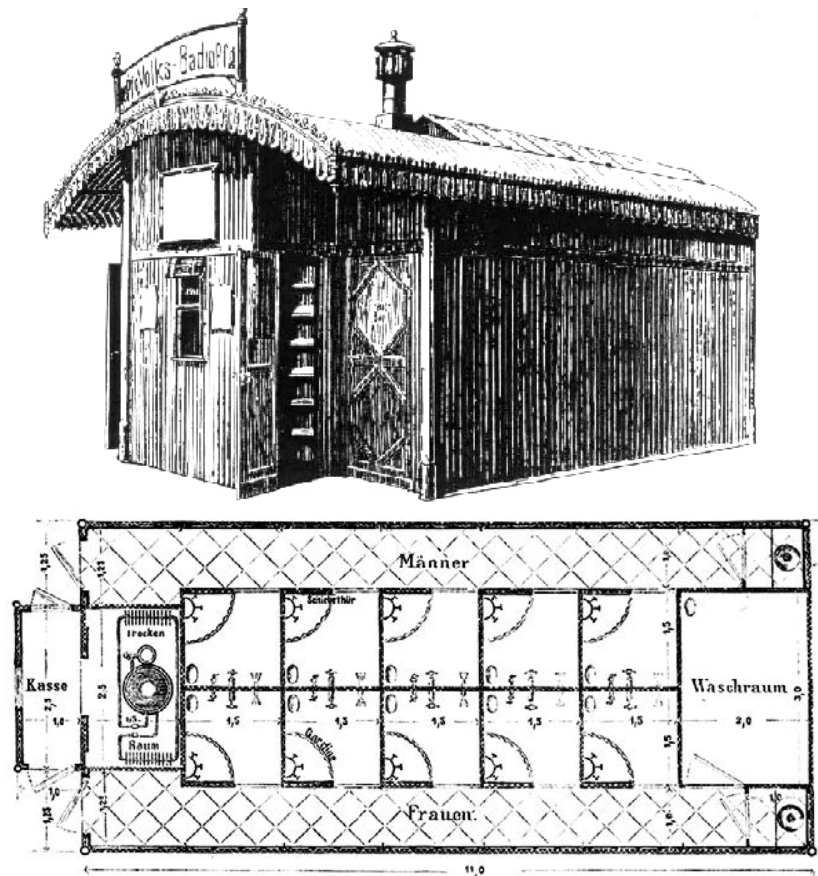

magen exterior y planta de los baños públicos diseñados por Oscar Lassar para e departamento de Higiene de Berlín, Alemania, 1882-83,

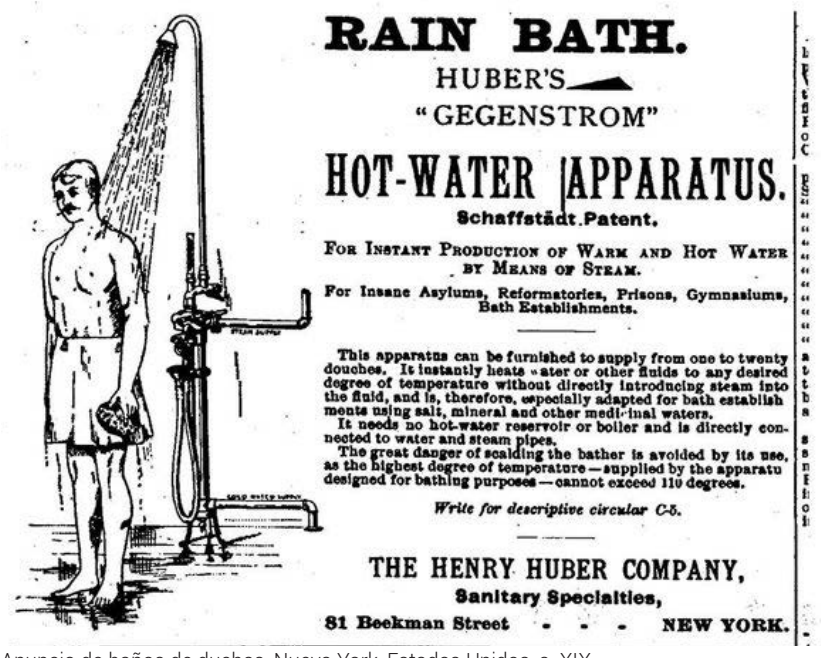

Anuncio de baños de duchas, Nueva York, Estados Unidos, s. XIX.
Las estaciones de limpieza

urbanas ofrecer cuartos de baños privados para toda la población debido a su alto coste, el Estado comienza a preocuparse por higienizar a una masa obrera enferma que pone en peligro la salud de la comunidad, buscando soluciones para llevar a cabo esta limpieza. La promoción de las casas públicas de baños en las ciudades se convierte en una solución. A pesar de que los baños públicos hacen su aparición en Inglaterra a partir de $1840^{298}$, no es hasta finales del siglo XIX, a partir de la Exposición de Higiene de Berlín de 1883, cuando aparecen en las principales ciudades europeas, impulsados por el doctor Lassar los establecimientos públicos o 'estaciones públicas de limpieza'299. Están compuestas por cabinas de ducha concebidas para las masas y son capaces de facilitar orden y salud en la higiene popular ${ }^{300}$.

En todos ellos la ducha, frente a la bañera burguesa, se constituye como el dispositivo ideal de limpieza. Avalado tanto por sus propiedades hidropáticas e higiénicas como por sus ventajas económicas, ya que consume menos agua y menos tiempo, ocupa menos espacio y además requiere menos reparaciones.

La ducha popular Gradualmente, en el siglo XIX, sobre todo entre 1850 y 1890, la ducha se convierte en el elemento de higiene más popular, como lo demuestran los catálogos de 1880, que dedican más espacio en sus páginas a este dispositivo que a primitivas bañeras. Este éxito se relaciona, por un lado, con los beneficios hidropáticos impulsados desde principios del siglo XIX por los terapeutas, y, por otro, con razones económicas, ya que las duchas consumen menos agua, menos espacio, menos tiempo y requieren menos reparaciones 301302.

297 GUERRAND, Roger-Henri. Op.cit. 106. 298 GIEDION, Siegfried. Op.cit. 671.

299 GIEDION, Siegfried. Op.cit. 674/WRIGHT, Lawrence. Op.cit. 19

300 VIGARELLO, Georges. Op.cit. 30

301 Sin embargo, el uso de duchas sanitarias no es nuevo. Se emplean por primera vez en 1860 por parte de unos colectivos específicos: el ejército y la
penitenciaría. Este es el caso de la prisión de Bonne-Nouvelle, de Ruan, donde existen duchas colectivas a aunque el sistema de chorro era individual El sistema militar francés, pionero en la rutinización de la producción industrial en los arsenales del siglo XVIII, es también el precursor en combinar los efectos de la

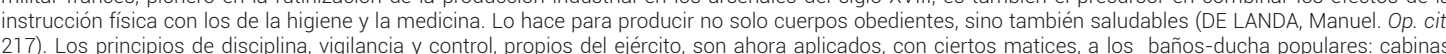
estrechas chorros contiscos da, wigla tia y control, propios

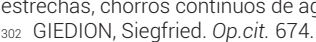




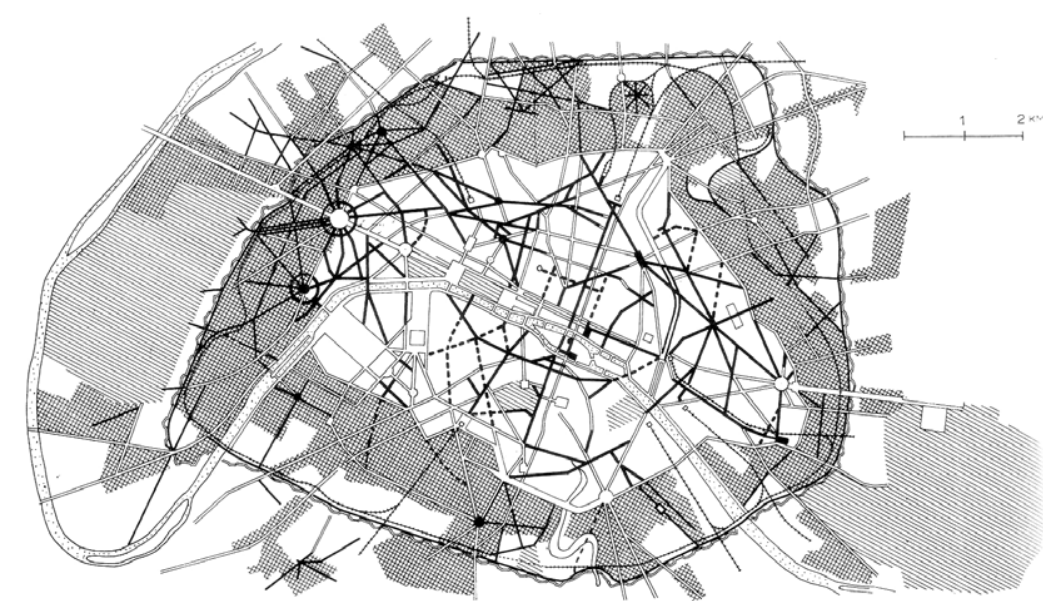

Plano de las intervenciones del plan Haussmann para París, Francia, durante la segunda mitad del s. XIX.

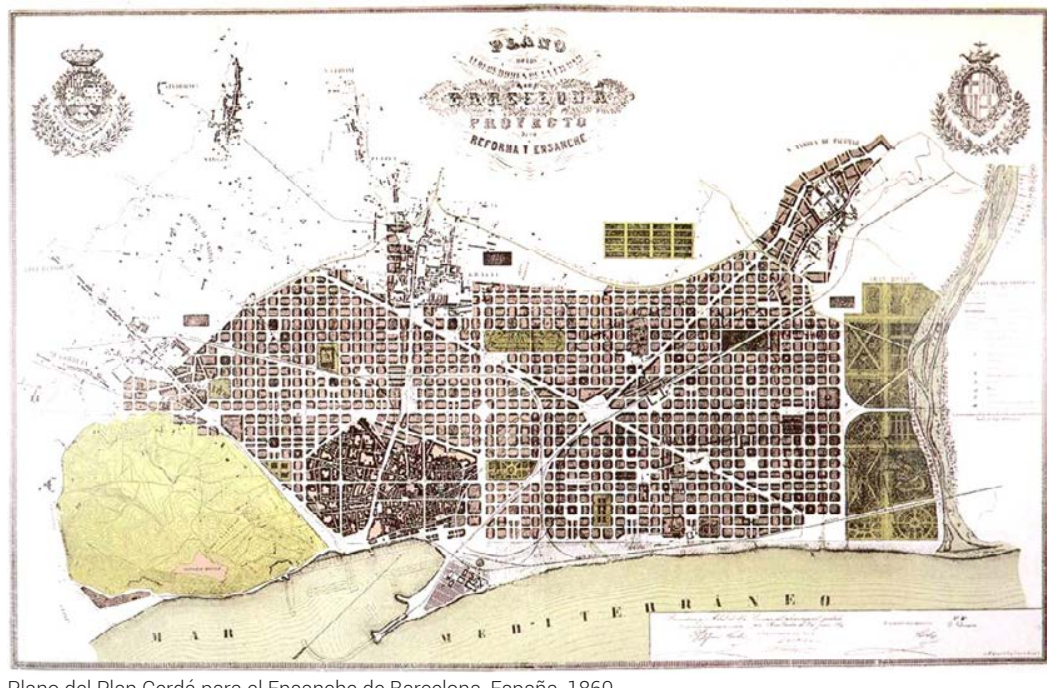

Plano del Plan Cerdá para el Ensanche de Barcelona, España, 1860
El ritual de limpieza de la población a través de los baños públicos constituye, junto a los sistemas de vacunación, iniciados a finales del siglo XVIII, ${ }^{303}$ junto al desarrollo de instituciones médico-militares del XIX ${ }^{304}$, el tercer dispositivo cuya combinación permite al Estado controlar al individuo. Se preserva así a poblaciones enteras de enfermedades en beneficio de la comunidad 305

En los inicios del siglo XX empieza a consolidarse la fase neotécnica de la humanidad ${ }^{306}$, iniciada en torno a la segunda mitad del siglo XIX la ciudad queda transformada por la interacción de fuerzas técnicas y socioeconómicas debido a la Revolución Industrial. Estas mutaciones van ligadas a un descenso de la tasa de mortalidad gracias a la mejora de los niveles de nutrición y de técnicas médicas. Vienen también acompañadas de una emigración masiva de la población del campo, con escasa capacidad adquisitiva, a los grandes núcleos urbanos, originando concentraciones urbanas sin precedentes.

La necesidad de alojar a la nueva población encuentra en la división y en la compartimentación de las viviendas del casco histórico una primera solución, lo que convierte a la ciudad en un contenedor de miseria ${ }^{307}$.

Los ensanches de las Simultáneamente, se lleva a cabo la modernización, mejora y ciudades dels.XIX expansión de las ciudades a través de distintas operaciones urbanísticas $^{308}$. Entre estas se encuentra el pionero plan Haussmann para París, de 1852, y los Ensanches -grandes superficies de terrenos retenidos por el capital inmobiliario ${ }^{309}$-, que suponen la expulsión definitiva, gracias al apoyo de los propietarios del suelo, de las nuevas clases obreras de los límites de la ciudad. 